UNIVERSIDADE DE SÃO PAULO

INSTITUTO DE FÍSICA DE SÃO CARLOS

CAIO VAZ RIMOLI

Mecanismos de interação molecular de polieletrólitos antimicrobianos em membranas modelo por espectroscopia vibracional não linear 



\section{Mecanismos de interação molecular de polieletrólitos antimicrobianos em membranas modelo por espectroscopia vibracional não linear}

Dissertação apresentada ao Programa de Pós-Graduação em Física do Instituto de Física de São Carlos da Universidade de São Paulo, para obtenção do título de Mestre em Ciências.

Área de concentração: Física Aplicada Opção: Física Biomolecular Orientador: Prof. Dr. Paulo Barbeitas Miranda

\section{Versão Corrigida}

(Versão original disponível na Unidade que aloja o Programa)

São Carlos 
AUTORIZO A REPRODUÇÃO E DIVULGAÇÃO TOTAL OU PARCIAL DESTE TRABALHO, POR QUALQUEER MEIO CONVENCIONAL OU ELETRÓNICO PARA FINS DE ESTUDO E PESQUISA, DESDE QUE CITADA A FONTE.

Ficha catalográfica revisada pelo Serviço de Biblioteca e Informaçāo do IFSC, com os dados fornecidos pelo(a) autor(a)

Rimoli, Caio Vaz

Mecanismos de interaça molecular de

polieletrolitos antimicrobianos em membranas modelo

por espectroscopia vibracional nào linear / Caio

Vaz Rimoli; orientador Paulo Barbeitas Miranda -

versto corrigida -- Sa Carlos, 2015.

$$
153 \mathrm{p} \text {. }
$$

Dissertaçào (Mestrado - Programa de Pós-Graduaçào em Fisica Biomolecular) -- Instituto de Fisica de Sấo Carlos, Universidade de Sào Paulo, 2015.

1. Espectroscopia vibracional nâo linear. 2. SFG. 3. Filmes de Langmuir. 4. Polieletrólitos

antimicrobianos. 5. Quitosana. I. Miranda, Paulo Barbeitas, orient. II. Titulo. 
Dedico este meu trabalho ao meu querido avô, Cosme Antônio Sebastião Rímoli - o Tié, que me chamava de Dr. Caio desde quando eu era criança. Infelizmente, você não está mais aqui comigo para eu compartilhar as minhas novas conquistas.

Enfim, eu ainda não sou doutor, Tié.

Mas eu prometo que um dia eu tornarei essa sua esperança

em a uma linda Profecia.

Obrigado pelo seu exemplo de vida.

(Tié faleceu no meu aniversário do primeiro ano do mestrado, no dia 29/Ago/2013). 



\section{AGRADECIMENTOS}

A Deus, por tudo e por cada segundo de vida.

A toda minha família, pelo amor, exemplo, suporte e compreensão em todos os momentos. Em especial: Pai, obrigado por me ensinar a ser paciente e organizado; Mãe, obrigado por me ensinar a trabalhar com amor e determinação; Maninha, obrigado por nunca me deixar esquecer que é a companhia das pessoas queridas que faz a vida valer a pena.

Ao Prof. Dr. Paulo Barbeitas Miranda, que foi um orientador exemplar, tanto do ponto de vista profissional como também do ponto de vista pessoal. Muito obrigado por toda a sua paciência, amizade, didática, dedicação e supervisão. Obrigado por toda essa experiência, por acreditar em mim e pelo excelente tempo que passamos juntos!

Aos meus grandes amigos que me aguentam desde o período da graduação: Rafael Tuma Guariento (Hipo), Luis Felipe Santos Mendes, Jéssica Baleiro Okado (Prê), Waldomiro Thiago Corsi (Sam), André Monteiro Paschoal (Guarda), Marcela Nunes Argentin(Pré), João Victor de Souza Cunha (Rosinha) e Ruan Neves (Perigoso) pela amizade, risadas, discussões científicas, churrascos e cervejadas.

A todos os funcionários, pesquisadores e alunos do Grupo de Polímeros "Prof. Bernhard Gross". Graças a vocês, o Grupo de Polímeros é um local fantástico de se fazer pesquisa e de se desenvolver. Obrigado pela amizade, companhia, suporte, profissionalismo, discussões e aprendizado que vocês proporcionam. Vocês são uma linda família. Em particular, sou muito grato ao Prof. Dr. Osvaldo Novais de Oliveira Jr., pela confiança, conversas extremamente motivadoras e por todo seu apoio. Sou também muito grato ao casal Dra. Thatyane Nobre Pavinatto e Dr. Felippe Pavinatto, pelas sugestões e instruções sobre os experimentos com Cuba de Langmuir. A todos os amigos que frequentam o Laboratório de Espectroscopia Não Linear de Interfaces (LENI), à Ma. Jaciara Cássia, ao Dr. Diogo Volpati e ao Me. Douglas Correia, ao Me. Marcos Felipe Sampaio pelas valiosas discussões a respeito da Técnica de Espectroscopia Vibracional por Geração de Soma de Frequências. Aos técnicos de laboratório Dra. Débora Balogh e Me. Bruno Bassi, pela excelente supervisão no laboratório de química. Às secretárias do grupo, Rô e Si, pela paciência, profissionalismo e orientações a respeito de burocracias 
acadêmicas. Ao Dr. Jorge Delezuk, por me fornecer e caracterizar as amostras de oligômeros de quitosana. Ao Me. Douglas Coutinho, ao Dr. Adriano Souza, à Dra. Heveline Follmann, à Dra. Simone Reis, ao Me. Daniel Roger, à Nathália Aprille, entre tantos outros companheiros pela amizade e companhia no período. Aos três técnicosmosqueteiros: Níbio, Bertho e Ademir pelo apoio técnico e toque de bom humor nos intervalos da copinha.

A todos os docentes dos quais fui aluno - muito obrigado pela dedicação e paciência.

Aos funcionários do Serviço da Pós-Graduação do IFSC, Silvio, Ricardo e Priscila, pelo profissionalismo, paciência e atenção.

Às meninas da biblioteca, Cris, Neusa e Ana, por sempre serem muito atenciosas, pacientes e dispostas a ajudar com as normas e bibliografia. Muito obrigado pela enorme ajuda de vocês!

Ao Instituto de Física de São Carlos (IFSC/USP) e a todos que trabalham nele, por proporcionar este excelente programa de pós-graduação em Física Aplicada. Da mesma forma, à Universidade de São Paulo (USP) e a todos que nela trabalham, por proporcionar esta infraestrutura pública exemplar.

Às agências de fomento: a Fundação de Amparo à Pesquisa do Estado de São Paulo (FAPESP) pela bolsa de mestrado no período final do mestrado (Jan/2014 Jul/2015) e ao Conselho Nacional de Desenvolvimento Científico e Tecnológico (CNPq), pelos 6 meses iniciais de bolsa de mestrado (Ago/2013).

Enfim, a todos os que estiveram presentes nesta longa trajetória, que eu já tenha mencionado ou não: saibam que eu sou um pedacinho de cada um de vocês e eu sou muito grato pela nossa convivência e experiência de vida compartilhada. Muito obrigado! 
Sapere Aude!

"Ouse saber!"

- Immanuel Kant -

"Nenhum vento sopra a favor de quem não sabe para onde ir".

- Sêneca - 



\section{RESUMO}

RIMOLI, C. V. Mecanismos de interação molecular de polieletrólitos antimicrobianos em membranas modelo por espectroscopia vibracional não linear. 2015. 153 p. Dissertação (Mestrado em Ciências) - Instituto de Física de São Carlos, Universidade de São Paulo, São Carlos, 2015.

Pesquisa em novas moléculas e estratégias antimicrobianas é crucial devido ao aumento de resistência a antibióticos pelos microrganismos. Polímeros antimicrobianos tem várias vantagens quando comparados a outros biocidas pequenos: maiores tempo de vida, potência, especificidade e baixa toxicidade residual. Logo, outras aplicações tecnológicas como recobrimentos, embalagens ou produtos têxteis antimicrobianos poderem ser exploradas. Em particular, derivados hidrossolúveis de quitosana, como os oligômeros de quitosana (OQ), são biopolímeros catiônicos extraídos de fontes renováveis que são candidatos promissores a serem agentes antimicrobianos de amplo espectro (fungos, bactérias gram-positivas e bactérias gram-negativas). Diferentemente da quitosana, que é sobretudo bioativa em pHs ácidos, OQ permanece catiônico - e portanto ativo - em pH fisiológico. Não obstante, o mecanismo exato pelo qual o polímero age nas membranas celulares permanece desconhecido em nível molecular. Este trabalho visa investigar o mecanismo de interação entre os OQ e modelos de membrana biomiméticos (Filmes de Langmuir). Para comparação, outro polieletrólito catiônico sintético com propriedades antibacterianas, o PAH - poli(hidrocloreto de alilamina) - foi investigado. Nós realizamos a Espectroscopia por Geração de Soma de Frequência (SFG) em Filmes de Langmuir de fosfolipídeos em água pura e em subfases contendo antimicrobianos. A Espectroscopia SFG nos permite obter o espectro vibracional de moléculas interfaciais (filme lipídico e moléculas que estão interagindo com ele: água e antimicrobianos) sem nenhuma contribuição de moléculas do interior do volume e é muito sensível às conformações lipídicas da membrana. Um fosfolipídeo zwitteriônico (DPPC) foi usado para modelar membranas tipo-humana, enquanto outro carregado negativamente (DPPG) modelava a tipo-bacteriana. Isotermas em subfases contendo antimicrobianos mostraram que ambos PAH e OQ causam uma pequena expansão das monocamadas de DPPC. Entretanto, para as monocamadas de DPPG ambos os polieletrólitos geraram uma expansão significativa. Entre eles, os OQ causaram um efeito mais drástico. Espectros SFG dos estiramentos $\mathrm{CH}$ mostraram que a 
conformação lipídica permaneceu bem empacotada em todos os casos (ligeiramente menos ordenada com PAH) apesar das expansões da membrana. Isto indica que os $\mathrm{OQ}$ foram inseridos formaram ilhas de $\mathrm{OQ}$ dentro do filme lipídico. Mudanças na forma de linha dos estiramentos da água interfacial indicaram que a adsorção de PAH em ambos os filmes foram capazes de compensar as cargas negativas, gerando uma inversão de cargas na superfície. Os espectros SFG dos grupos fosfato também indicaram que, em água pura, as cabeças polares de DPPC estão com uma orientação mais ordenada do que no caso do DPPG. Contudo, quando interagindo com os polieletrólitos catiônicos, as cabeças dos DPPGs se ordenam, ficando preferencialmente perpendicular à interface. Experimentos com antimicrobianos injetados na subfase enquanto os filmes de Langmuir já estavam condensados indicaram que os $\mathrm{OQ}$ foram capazes de penetrar na monocamada, embora causando uma expansão no filme menor. Esta comparação evidencia que a escolha da metodologia experimental afeta o resultado, mas ambas podem ser complementares, visto que podem representar diferentes fases do ciclo celular das biomembranas. A visão detalhada provida aqui para as interações moleculares desses polieletrólitos com filmes lipídicos podem os elucidar mecanismos de atividade biocida deles e auxiliar no planejamento racional de novos polímeros antimicrobianos.

Palavras chave: Espectroscopia vibracional não linear. SFG. Filmes de Langmuir. Polieletrólitos antimicrobianos. Quitosana. 


\begin{abstract}
RIMOLI, C. V. Mechanisms of molecular interaction between antimicrobial polyelectrolytes and membrane models by nonlinear vibrational spectroscopy. 2015. 153 p. Dissertação (Mestrado em Ciências) - Instituto de Física de São Carlos, Universidade de São Paulo, São Carlos, 2015.
\end{abstract}

Research on new antimicrobial molecules and strategies is crucial due to the increasing microorganism resistance to antibiotics. Antimicrobial Polymers have many advantages when compared to other small biocides: increased lifetimes, potency, specificity and lower residual toxicity. Therefore, they have great potential for technological applications, such as antimicrobial coatings, packages, or textile products. In particular, water-soluble derivatives of chitosan, such as chitosan oligomers (CO), are cationic biopolymers obtained from renewable sources that are promising candidates to a widespectrum antimicrobial agent (fungi, gram positive and gram negative bacteria). Unlike chitosan, which is mainly bioactive at acidic $\mathrm{pH}, \mathrm{CO}$ remain cationic - and therefore active - at physiological $\mathrm{pH}$. Nevertheless, the exact mechanism by which this polymer acts on the cell membranes remains unknown at the molecular level. This work aims at investigating the molecular interaction between $\mathrm{CO}$ and a biomimetic cell membrane model (Langmuir Film). For comparison, another synthetic cationic polylelectrolyte with antibacterial properties, PAH - poly(alylamine hydrochloride), has been investigated. We have carried out Sum-Frequency Generation (SFG) Spectroscopy on Langmuir Films of phospholipids on pure water and on antimicrobial containing subphases. SFG Spectroscopy allows obtaining the vibrational spectrum of interfacial molecules (lipid Langmuir Film and molecules interacting with it - water and antimicrobials), without any contribution from the bulk molecules, and is quite sensitive to the conformation of membrane lipids. A zwitterionic phospholipid (DPPC) was used to model human-like membranes, while a negatively charged phospholipid (DPPG) modeled bacterial-like membranes. Surface pressure-area isotherms on antimicrobial-containing subphases showed that both PAH and CO led to a small expansion of DPPC monolayers. However, for DPPG monolayers both polyelectrolytes led to significant expansion, with CO causing a more dramatic effect. SFG spectra in the $\mathrm{CH}$ stretch range showed that the lipid chain conformation remained always well ordered in all cases (slightly less ordered upon interacting with $\mathrm{PAH}$ ), despite membrane expansion. This indicates that $\mathrm{CO}$ were inserted in the monolayer, forming islands of $\mathrm{CO}$ within the lipid film. Changes in the SFG 
spectral lineshape of $\mathrm{OH}$ stretches for the interfacial water molecules indicated that PAH adsorption on both DPPC and DPPG films was able to overcompensate the lipid negative charge and led to an overall surface charge reversal. The SFG spectra of the phosphate groups also indicated that in pure water the DPPC headgroups had a more ordered orientation than in the case of DPPG. Nevertheless, upon interaction with the cationic polyelectrolytes, the DPPG headgroups also become ordered, with a preferential orientation towards the subphase. Experiments with the antimicrobials injected in the subphase under a condensed Langmuir film indicated that CO were also capable of monolayer penetration, albeit causing a reduced film expansion. This comparison indicates that the choice of experimental methodology affects the outcome, but both may be complementary, as they may represent different phases of a biomembrane lifecycle. The detailed view provided here for the molecular interaction of these polyelectrolytes with lipid films may shed light on the mechanism of their biocidal activity and aid on a rational design of new antimicrobial polymers.

Keywords: Nonlinear vibrational spectroscopy. SFG. Langmuir films. Antimicrobial polyelectrolytes. Chitosan. 


\section{LISTA DE FIGURAS}

$\begin{array}{lll}\text { FIGURA } 01 \quad \text { Alvos moleculares tradicionais } & 23\end{array}$

FIGURA 02 Mecanismos de defesa a antibióticos 24

FIGURA $03 \quad$ Biofilmes bacterianos 26

FIGURA 04 Mecanismos de aquisição de resistência a antibióticos 29

FIGURA 05 Principais mecanismos de interação com membranas 34

$\begin{array}{lll}\text { FIGURA } 06 & \text { Reação de síntese de quitosana } & 37\end{array}$

FIGURA 07 Células procarióticas e eucarióticas 49

FIGURA 08 Micrografias de células procarióticas e eucarióticas 51

FIGURA 09 Membrana como um mosaico fluido 51

FIGURA 10 O método de coloração Gram 53

FIGURA 11 Classificação clássica de bactérias $\quad 54$

FIGURA 12 Biomembranas de bactérias Gram-positivas 55

FIGURA 13 Biomembranas de bactérias Gram-negativas 57

FIGURA 14 Estruturas químicas de alguns lipídeos importantes 59

$\begin{array}{lll}\text { FIGURA } 15 & \text { Principais modelos de membrana }\end{array}$

FIGURA 16 Tensão superficial $\quad 65$

$\begin{array}{lll}\text { FIGURA } 17 \text { Método de Wilhelmy } & 67\end{array}$

FIGURA $18 \quad$ Cuba de Langmuir $\quad 69$

$\begin{array}{lll}\text { FIGURA } 19 & \text { Experimento de compressão isotérmica }\end{array}$

$\begin{array}{lll}\text { FIGURA } 20 & 0 \text { colapso de um Filme de Langmuir }\end{array}$

$\begin{array}{lll}\text { FIGURA } 21 & \text { Exemplo de experimentos de compressão isotérmica } & 73\end{array}$

FIGURA 22 Respostas lineares do meio 76

$\begin{array}{lll}\text { FIGURA } 23 & \text { Respostas não lineares do meio }\end{array}$

FIGURA 24 Referencial de laboratório e combinações das polarizações $\quad 83$

FIGURA 25 A espectroscopia SFG 86

FIGURA 26 Parâmetro R nos espectros SFG de combinação (s, s, p) 90

FIGURA 27 Polieletrólitos catiônicos antimicrobianos utilizados 94

FIGURA 28 Caracterização dos oligômeros de quitosana (OQ) 95

FIGURA 29 O lab. de espectroscopia não linear de interfaces (LENI) 97 
FIGURA $30 \quad$ O espectrômetro SFG 98

FIGURA 31 Isotermas em membranas modelo "tipo-humanas" 101

FIGURA 32 Isotermas em membranas modelo "tipo-bacterianas" 103

FIGURA 33 Espectros SFG de membrana "tipo-humana” - Pt 1

FIGURA 34 Mecanismo de interação em membranas "tipo-humana" - Pt 1108

FIGURA 35 Espectros SFG de membrana "tipo-bacteriana" - Pt 1

FIGURA 36 Espectros SFG de membrana com OQ “tipo-bacteriana” - Pt 1111

FIGURA 37 Espectros SFG de membrana com PAH “tipo-bacteriana” - Pt 1112

FIGURA 38 Mecanismo de interação em membranas “tipo-bacteriana” - Pt 1113

FIGURA 39 Espectros SFG (SSP) de membrana "tipo-humana"- Pt 2

FIGURA 40 Espectros SFG (SPS) de membrana “tipo-humana”- Pt 2

FIGURA 41 Espectros SFG (PPP) de membrana "tipo-humana"- Pt 2

FIGURA 42 Espectros SFG (SSP) de membrana “tipo-bacteriana"- Pt 2

FIGURA 43 Espectros SFG (SPS) de membrana “tipo-bacteriana"- Pt 2

FIGURA 44 Espectros SFG (PPP) de membrana “tipo-bacteriana”- Pt 2118

FIGURA 45 Dinâmica de penetração de OQ em membrana "tipo-bacteriana" 121

FIGURA 46 Comparando metodologias - espectros SFG em água pura 124

FIGURA 47 Comparando metodologias - metodologia \#1 - DPPG-OQ 125

FIGURA 48 Comparando metodologias - metodologia \#2 - DPPG-OQ 125

FIGURA 49 Mecanismos de interação com membranas "tipo-humanas" 127

FIGURA 50 Mecanismos de interação com membranas “tipo-bacteriana” 128 


\section{LISTA DE TABELAS}

TABELA 01 Estruturas químicas de antibióticos em uso clínico 22

TABELA 02 Classificação polimérica 32

TABELA 03 Diferenças intracelulares entre eucariotos e procariotos 50

TABELA 04 Estrut. químicas de alguns monossacarídeos nos LPS 58

TABELA 05 Fosfolipídeos majoritários nas membranas celulares 60

$\begin{array}{lll}\text { TABELA } 06 & \text { Fenômenos não lineares de segunda ordem } & 79\end{array}$

TABELA 07 Resumo de algumas propriedades de simetria de $\overleftrightarrow{\chi}^{(2)} 81$

TABELA $08 \quad \chi_{i, j, k}^{(2)}$ geradores de SFG em interfaces com simetria Co 82

TABELA 09 Polarizações dos campos (SFG, VIS, IR) e os $\chi_{i, j, k}^{(2)} \quad 83$

TABELA 10 Fosfolipídeos utilizados nos Filmes de Langmuir 93

TABELA 11 Estiramentos $\left(\mathrm{PO}_{2}\right)$ - do grupo fosfato $\left(\mathrm{PO}_{4}\right)-$

$\begin{array}{lll}\text { TABELA } 12 \text { Estiramentos de grupos alquila } & 105\end{array}$

TABELA 13 Estiramentos de O-H da água 105

TABELA 14 Estiramentos típicos dos polieletrólitos antimicrobianos 106 



\section{SUMÁRIO}

1 CONTEXTUALIZAÇÃO ............................................................ 21

1.1 FATOS PREOCUPANTES........................................................................................... 21

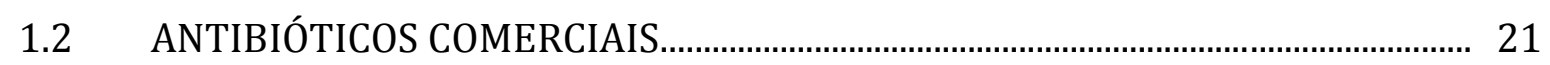

1.3 MECANISMOS DE RESISTÊNCIA A ANTIBIÓTICOS CONHECIDOS.......................... 24

1.4 A AQUISIÇÃO DE RESISTÊNCIA A ANTIBIÓTICOS.................................................... 28

1.5 ANTIMICROBIANOS POLIMÉRICOS.................................................................... 31

1.6 ESTRATÉGIAS PROMISSORAS DE COMBATE A MICRORGANISMOS................... 32

1.7 MODOS DE PERTURBAÇÃO DE MEMBRANAS........................................................... 34

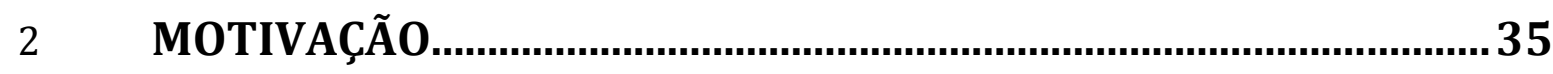

2.1 O ESTADO DA ARTE (QUITOSANAS EM MODELOS DE MEMBRANA).................. 38

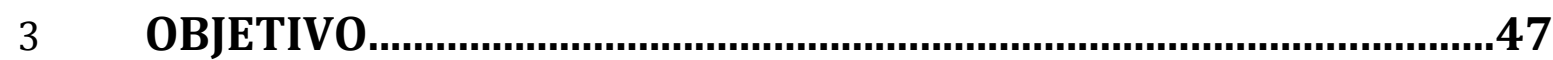

4 SEÇÃO TEÓRICA......................................................................... 49

4.1 FUNDAMENTOS DA ESTRUTURA CELULAR....................................................... 49

4.1.1 Células.............................................................................................................. 49

4.1.2 Membranas Biológicas........................................................................................ 51

4.1.3 A Estrutura Molecular das Membranas................................................................... 52

4.1.4 Biomembranas Bacterianas................................................................................... 52

4.1.4.1 Biomembranas de Bactérias Gram + ............................................................... 54

4.1.4.2 Biomembranas de Bactérias Gram - ................................................................ 55

4.1.5 Composição lipídica das membranas celulares....................................................... 58

4.2 MODELOS DE MEMBRANA CELULAR................................................................ 61

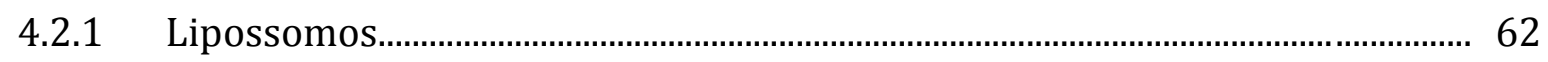

4.2.2 Filmes de Langmuir-Blodgett............................................................................ 63

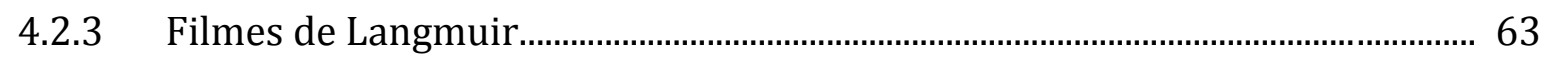

4.3 CONCEITOS BÁSICOS EM TERMODINÂMICA DE SUPERFÍCIES LÍQUIDAS..... 65

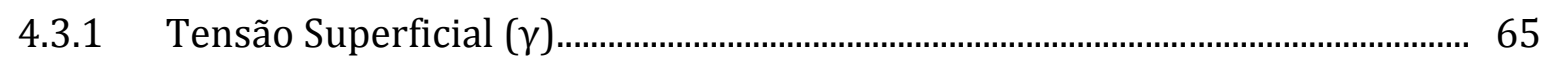

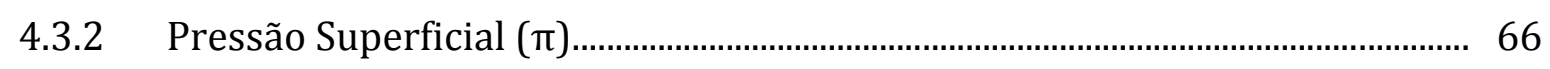


4.3.3 Princípio do método de Wilhelmy para medir Pressão Superficial.................... 67

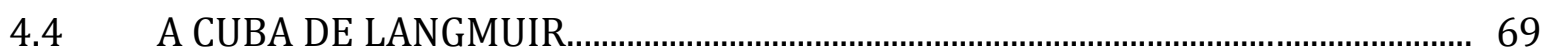

4.4.1 Membranas Biomiméticas: Pressões de Relevância Biológica............................ 70

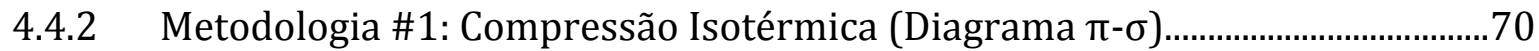

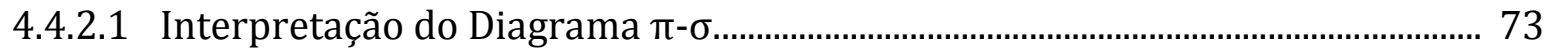

4.4.3 Metodologia \#2: Dinâmica Isobárica (Diagrama $\sigma-\mathrm{t}$ )............................................. 74

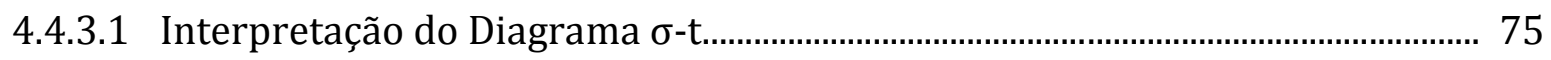

4.5 FUNDAMENTOS DE ÓPTICA NÃO LINEAR

4.5.1 Fenômenos Ópticos Lineares e Não Lineares........................................................... 76

4.5.1.1 Regime da Óptica Linear.......................................................................................... 76

4.5.1.2 Regime da Óptica Não Linear................................................................................... 77

4.5.1.2.1 Processos Ópticos Não Lineares de Segunda Ordem..................................... 78

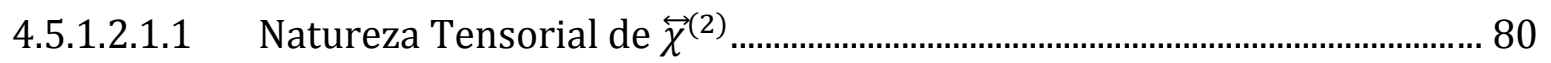

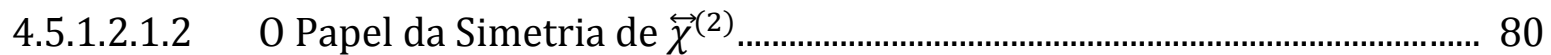

4.5.1.2.1.3 Interfaces Isotrópicas (com simetria $\mathrm{C}$ )

4.6 ESPECTROSCOPIAS NÃO LINEARES DE SEGUNDA ORDEM................................ 84

4.6.1 A Espectroscopia Vibracional Não Linear por SFG................................................ 85

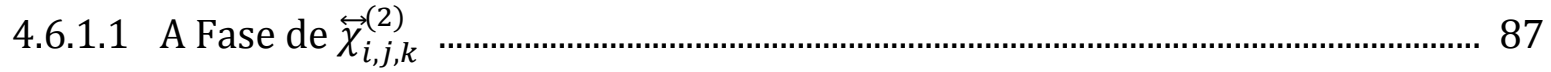

4.6.1.2 A combinação de polarizações (s, s, p) dos feixes (SFG, VIS, IR)........................... 89

4.6.1.2.1 Parâmetro (R) - Medindo conformações lipídicas........................................ 89

4.6.1.3 A combinação de polarizações (s, p, s) dos feixes (SFG, VIS, IR).............. 92

4.6.1.4 A combinação de polarizações (p, p, p) dos feixes (SFG, VIS, IR).............. 92

5 SEÇÃO EXPERIMENTAL ............................................................... 93

5.1 PREPARAÇÃO DE AMOSTRAS (FILMES DE LANGMUIR) ...................................... 93

5.1.1 Detalhes Experimentais da Compressão Isotérmica (\#1)..................................... 94

5.1.2 Detalhes Experimentais da Dinâmica Isobárica (\#2)............................................ 96

5.2 LENI - LAB. DE ESPECTROSCOPIA NÃO LINEAR DE INTERFACES.................... 96

5.2.1 Descrição do Sistema Óptico de Espectroscopia SFG........................................... 97 
6.1 ANÁLISE TERMODINÂMICA POR COMPRESSÃO ISOTÉRMICA ( $\pi-\sigma) \ldots . . . . . . . . . . . . . .101$

6.1.1 Membrana Biomimética "Tipo-Humana”............................................................... 101

6.1.2 Membrana Biomimética "Tipo-Bacteriana”............................................................. 103

6.2 ANÁLISE MOLECULAR POR ESPECTROSCOPIA SFG............................................. 104

6.2.1 Atribuições Ressonantes e Números de Onda Esperados.................................... 104

6.2.2 Espectros SFG das caudas lipídicas e da água interfacial..................................... 106

6.2.2.1 Interações Moleculares em Membrana “Tipo-Humana”....................................... 106

6.2.2.2 Interações Moleculares em Membrana "Tipo-Bacteriana”.................................... 109

6.2.3 Espectros SFG das cabeças polares dos fosfolipídeos ......................................... 114

6.2.3.1 Interações Moleculares em Membrana “Tipo-Humana”.................................... 114

6.2.3.2 Interações Moleculares em Membrana "Tipo-Bacteriana".................................. 117

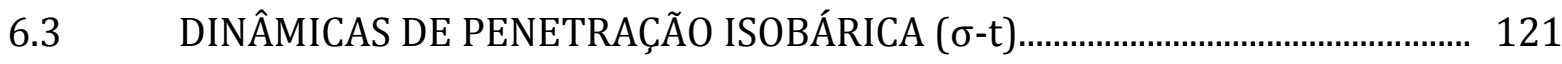

6.3.1 Ensaios de Injeção de Oligômeros de Quitosana (OQ)....................................... 121

6.4 INVESTIGANDO AS METODOLOGIAS [\#1|\#2] POR ESPECT. SFG ................... 124

6.4.1 Diferenças nas Interações de Oligômeros de Quitosana com Membrana "TipoBacteriana" durante sua: Formação ou Penetração ........................................... 124

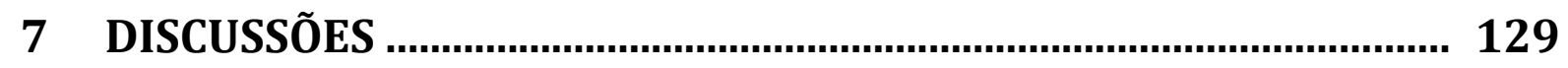

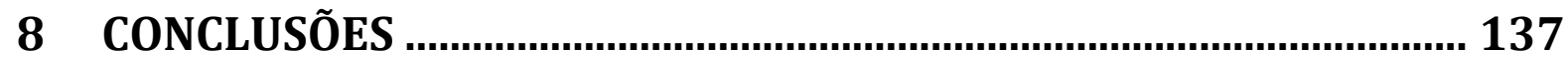

9 SUGESTÕES PARA FUTUROS EXPERIMENTOS.................................. 143

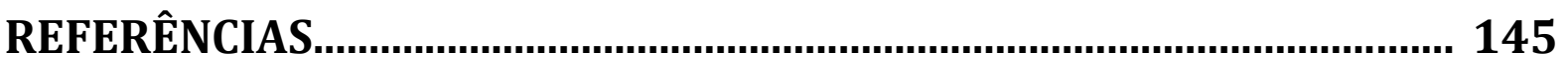





\section{CONTEXTUALIZAÇÃo}

\subsection{FATOS PREOCUPANTES}

Um terço de todos os óbitos no mundo é devido a doenças infecciosas ou parasitárias. ${ }^{1}$ Neste cenário, a crescente resistência aos antibióticos dos microrganismos (MOs) é um fato globalmente alarmante. Dados de 2011 da World Health Organization, $W H O,{ }^{2}$ relatam que só na União Europeia, Noruega e Islândia, cerca de 5 a 12\% dos pacientes hospitalizados adquirem uma infecção durante sua estadia. Destes, aproximadamente 400.000 estão infectados com um patógeno resistente e, infelizmente, cerca de 25.000 pacientes morrem por ano. Similarmente, o NIH, National Institutes of Health, relataram em 2012 que cerca de 5 a 10\% de todos os pacientes dos Estados Unidos desenvolvem uma infecção em seus hospitais. Destes, na década passada, morriam cerca de 13.000 pacientes ao ano. Atualmente, morrem 90.000 ao ano. ${ }^{3}$

Além de ser um problema bastante grave de saúde pública, a resistência dos microrganismos (MOs) a antibióticos também incorpora problemas políticos e econômicos. Pessoas infectadas com MOs resistentes permanecem mais tempo nos hospitais e, em geral, requerem um tratamento mais complicado. Consequentemente, MOs resistentes aumentam as despesas dos hospitais. Dados dos Centers for Disease Control and Prevention (2011) relatam que, só nos Estados Unidos, a resistência a antibióticos proporcionou um gasto de US\$20 bilhões por ano com despesas de assistência médica extras, US $\$ 35$ milhões com gastos sociais e 8 milhões de dias adicionais de pacientes que ficaram em seus hospitais. ${ }^{4}$ Urge-se, portanto, pesquisa e desenvolvimento de novos compostos antibióticos ou de novas estratégias antimicrobianas.

\subsection{ANTIBIÓTICOS COMERCIAIS}

Os antibióticos empregados em hospitais são, em geral, moléculas "pequenas" (TABELA 01) que têm a função bactericida (causam a morte celular) ou bacteriostática (impedem a multiplicação celular). ${ }^{5}$ Tipicamente, os bactericidas pequenos atuam inibindo alguma enzima (macromolécula) vital. Tal inibição geralmente obstrui a rota bioquímica de uma atividade ou síntese de estrutura celular importante (FIGURA 01). 
TABELA 01- ESTRUTURAS QUIIMICAS DE ANTIBIÓTICOS EM USO CLÍNICO.

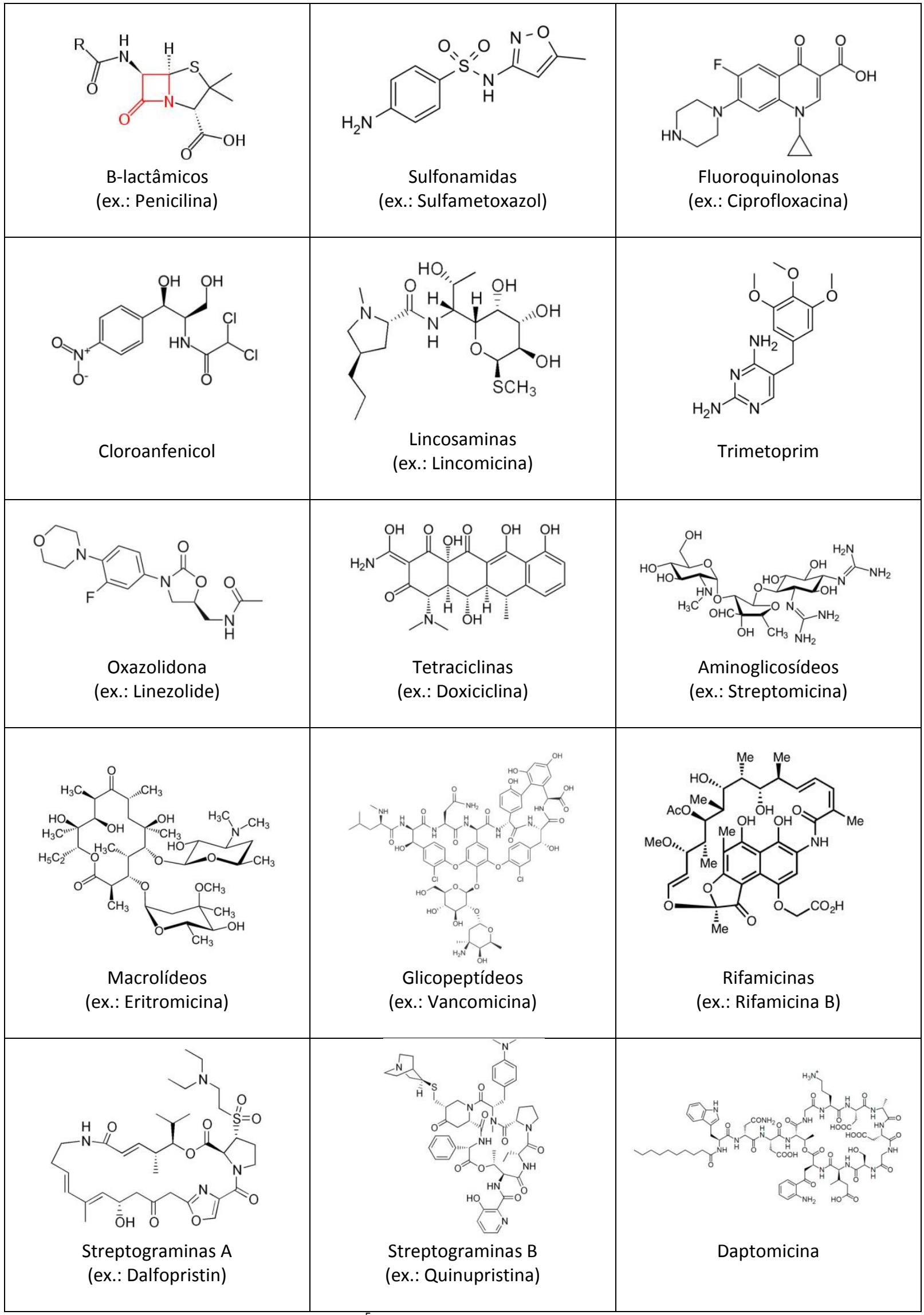

Fonte: Adaptada de BOCKSTAEL, AERCHOT. ${ }^{5}$ 
FIGURA 01 - ALVOS MOLECULARES TRADICIONAIS. Alvos moleculares típicos de compostos antimicrobianos em uso clínico. [1] Inibição da síntese de DNA (Replicação do DNA); [2] Inibição da síntese de RNA mensageiro (Transcrição do DNA); [3] Inibição da síntese de proteínas (Tradução do RNAm); [4] Interrupção de vias metabólicas importantes (ex.: biossíntese de folatos); [5] Inibição da síntese de parede celular. Exemplos dos respectivos antibióticos para [1] Fluoroquinolonas; [2] Rifamicinas; [3] Aminoglicosídeos, Tetraciclinas, Cloroamfenicol, Macrolídeos, Lincosamidas, Streptograminas, Oxazolidinonas; [4] Trimetroprim, Sulfonamidas (Inibição da Biossíntese de Folatos); [5] $\beta$-lactâmicos, glicopeptídeos. Observação: a Daptomicina (TABELA 01) é um antimicrobiano desenvolvido recentemente que ataca a membrana celular bacteriana, levando à rápida despolarização do potencial de membrana - já houve indícios do aparecimento de resistência durante as fases de ensaios clínicos. 5

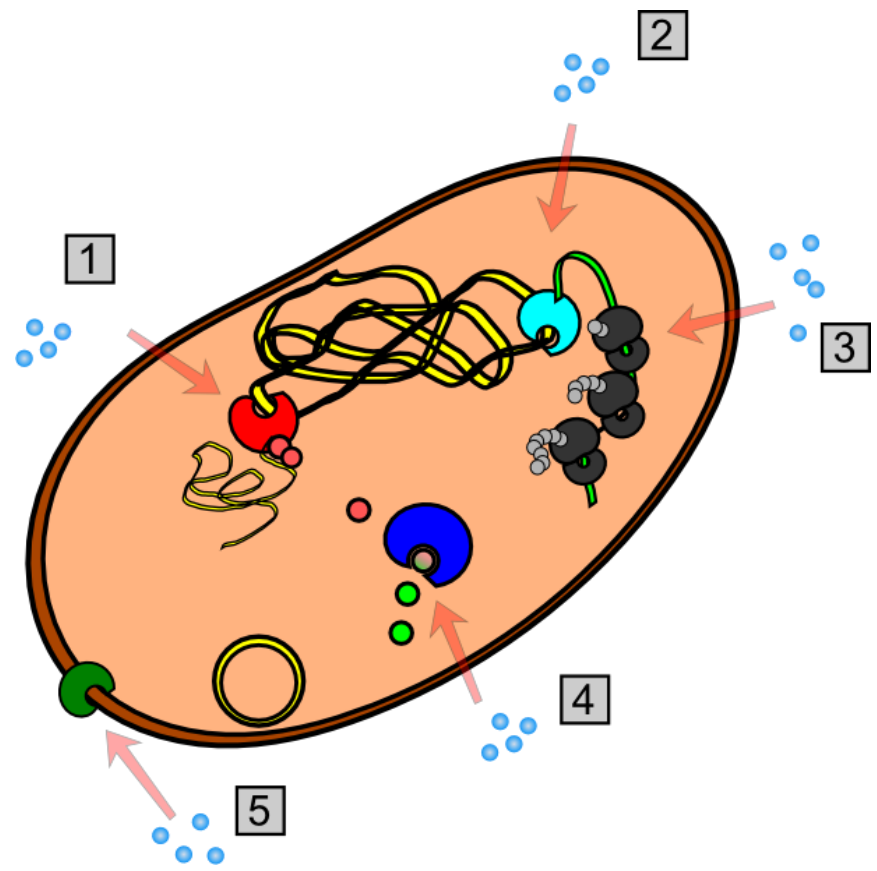

Legenda:

\begin{tabular}{|c|c|c|c|}
\hline$\because$ & Antimicrobianos & 8 & Proteína \\
\hline & DNA Plasmidial & & Ribossomo \\
\hline 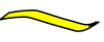 & DNA & $\square$ & Citoplasma \\
\hline & RNAm & 0 & Reagente \\
\hline & Enzimas & 0 & Produto \\
\hline
\end{tabular}

Fonte: Elaborada pelo autor. 


\subsection{MECANISMOS DE RESISTÊNCIA A ANTIBIÓTICOS CONHECIDOS}

O grande problema de utilizar antimicrobianos de baixa massa molecular (sobretudo os inibidores enzimáticos) é que é fácil de encontrar microrganismos (MOs) que apresentem resistência a eles. Há vários mecanismos conhecidos de resistência aos antibióticos de uso clínico. Muitos deles são bem caracterizados na literatura. ${ }^{7-10}$ Alguns exemplos estão ilustrados na FIGURA 02.

FIGURA 02 - MECANISMOS DE DEFESA A ANTIBIÓTICOS. Exemplos de mecanismos de resistência: [1] Enzima faz modificações químicas nos antibióticos; [2] macromolécula com uma afinidade altíssima pelo antibiótico captura-o e, em seguida, é degradada ou liberada para o meio extracelular; [3] a bactéria produz um Alvo Molecular modestamente modificado (ainda funcional) e a afinidade do antibiótico por este novo alvo é significativamente reduzida; [4] modificação da composição da parede celular e/ou da membrana plasmática; [5] Bombas de efluxo removem antibiótico intracelular; [6] Liberação de substâncias no meio extracelular que modificam quimicamente o antibiótico ou que impedem com que ele chegue ao MO. ${ }^{7-10}$

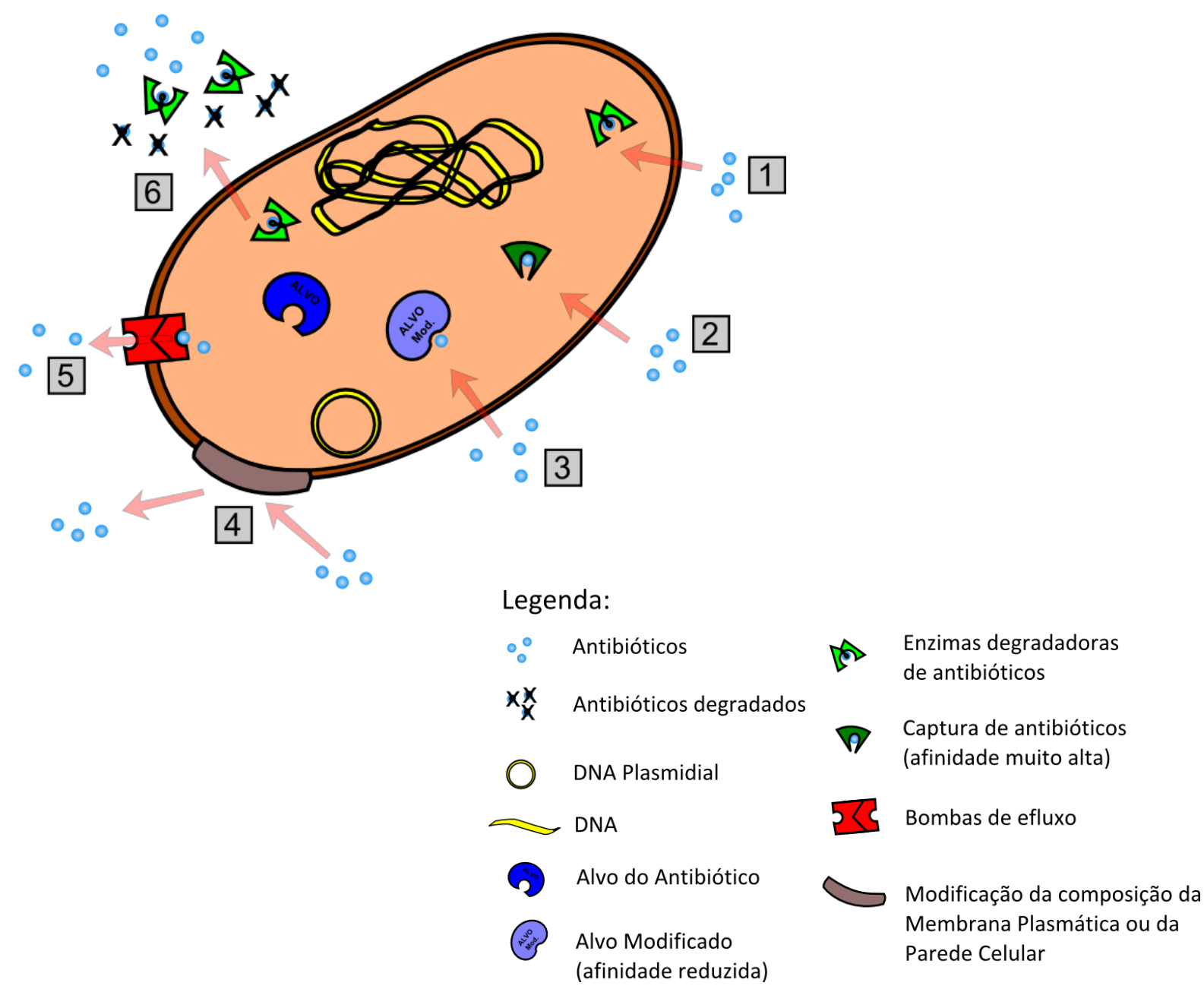

Fonte: Elaborada pelo autor. 
Em particular, bactérias formadoras de biofilmes podem ser extremamente perigosas em um ambiente hospitalar, uma vez que tais estruturas são capazes de protegê-las de uma diversidade de situações hostis. Biofilmes Bacterianos são comunidades bastante heterogêneas de bactérias que se aderem a superfícies inertes ou vivas por meio de uma matriz polimérica gelatinosa (cerca de 50\%-90\% são polissacarídeos). ${ }^{11} \mathrm{~A}$ matriz enclausura e estrutura as colônias de bactérias dentro deste hidrogel. Além disso, tem sua produção controlada pela própria comunidade microbiana (FIGURA 03). Cada biofilme é único: tem sua própria distribuição de microrganismos (bactérias e/ou fungos), moléculas sinalizadoras, dinâmica de arquitetura (canais, bolsões, porosidade, viscoelasticidade), mecanismo de dispersão, etc. ${ }^{12}$ Há na literatura evidências que biofilmes bacterianos fornecem proteção contra exposição de radiação ultravioleta, toxicidade de metais, exposição a ácidos, desidratação, salinidade, fagocitose e diversos antibióticos ou compostos antimicrobianos. ${ }^{12}$ Estima-se que a formação de biofilmes bacterianos diminui a susceptibilidade a agentes antimicrobianos em cerca de 1000 vezes quando comparados às colônias crescidas livres em um meio fluido convencional. ${ }^{11}$ 
FIGURA 03 - BIOFILMES BACTERIANOS. Os estágios de desenvolvimento de um biofilme de Pseudomonas aeruginosa e suas respectivas micrografias (de mesma escala especificada pela referência). [1] Estágio de Anexação Reversível de bactérias à superfície (inerte ou viva). A mudança na expressão gênica que muda o comportamento das bactérias nadadoras (planctônicas) para aderentes ocorre em minutos. Eventualmente, uma bactéria aderida na superfície pode voltar para o meio fluido. [2] Estágio de Anexação Irreversível. As bactérias aderidas iniciam comunicação intercelular (quorum-sensing) e a produção da matriz extracelular polimérica (MEP) começa a ser produzida. [3] Estágio de Maturação I (Proliferação). Com uma MEP já bem formada, ocorre uma troca maior de nutrientes e se inicia uma intensa proliferação. [4] Estágio de Maturação II. O biofilme é grande o suficiente para ter diferentes microambientes, com vários gradientes de substâncias e canais de água bem definidos. Fica evidente neste estágio que cada célula começa ter diferentes funções dentro do biofilme (quorum-sensing intenso). Há células que só produzem a matriz extracelular; outras que só se multiplicam; outras que entram em estágio de dormência ou são naturalmente mais resistentes (persistentes). [5] Estágio de dispersão: o biofilme é tão grande que começa a se despedaçar e o seu conteúdo se espalha para as vizinhanças. Algumas células se destacam do biofilme presas a pedaços da matriz extracelular polimérica, outras na forma plactônica (livres no fluido). Eventualmente tais bactérias livre-natantes encontram uma superfície para se aderir, reiniciando o ciclo de desenvolvimento de biofilmes. ${ }^{11-13}$

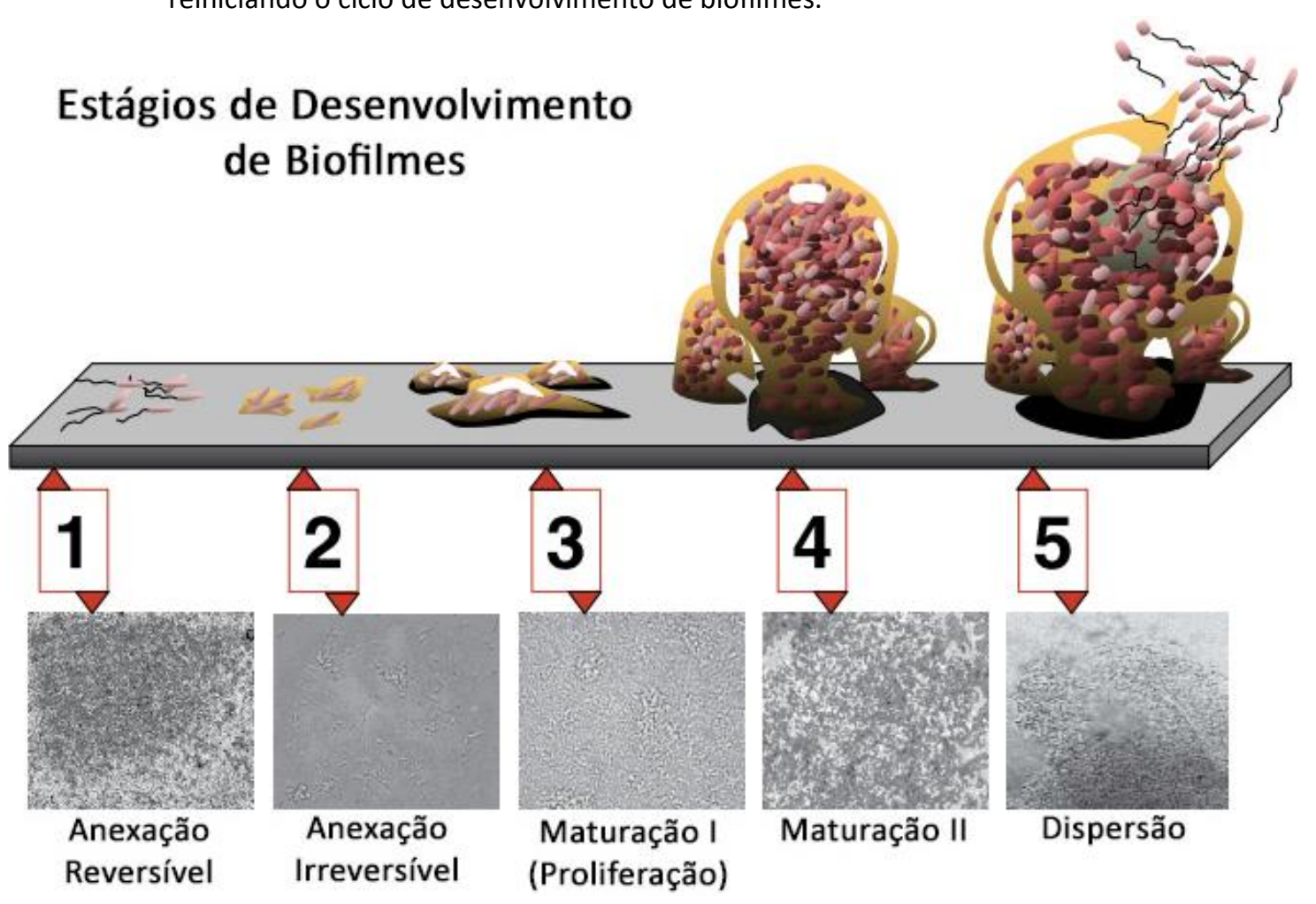

Fonte: Adaptada de MONROE. ${ }^{13}$

Três mecanismos principais foram propostos para explicar a resistência a tantos fatores externos. ${ }^{12} \mathrm{O}$ primeiro mecanismo é que a Matriz Extracelular Polimérica (MEP) age como uma primeira barreira: substâncias muito reativas atacariam a MEP em um primeiro momento. ${ }^{11,12}$ Então, tais moléculas pequenas e reativas seriam neutralizadas 
ou diluídas a concentrações subletais antes mesmo de chegar aos microrganismos (MOs) de interesse no interior. Além disso, a MEP absorve radiação UV, previne desidratação e contém enzimas extracelulares de proteção. O segundo mecanismo proposto está relacionado com o estado fisiológico das bactérias em seu interior. ${ }^{12}$ Como há uma heterogeneidade de ambientes (químico, físico e biológico) no interior do biofilme, é natural esperar que uma parcela das bactérias em seu interior esteja em uma zona desprivilegiada (por exemplo, sem nutrientes) e que isso propiciaria a ocorrência de encontrar MOs em estado dormente. Desta forma, por exemplo, antibióticos que agem em enzimas de divisão celular ou de formação de estruturas novas nas bactérias necessitam que tais patógenos estejam com uma atividade metabólica significativa para causar seu efeito. Portanto, bolsões no interior de biofilmes que são "zonas de dormência" podem representar um mecanismo geral de resistência a antibióticos. Quaisquer bactérias que estivessem nesses bolsões teriam sua atividade metabólica reduzida e, consequentemente, sua resistência aumentada a determinados antibióticos. Por fim, o terceiro possível mecanismo de proteção está relacionado à existência de uma diversidade de subpopulações dentro de cada espécie bacteriana do biofilme.12, 13 Algumas destas, em particular, poderiam ser subpopulações de fenótipos resistentes denominados "persistentes". Fenótipo é a característica observável (aparência ou comportamento) de um determinado indivíduo (célula ou organismo) que depende tanto de seu conjunto de genes (Genótipo), quanto de fatores ambientais e/ou de seu período de vida. Acredita-se que tais bactérias persistentes compõem uma pequena fração de toda a biomassa do biofilme. Porém, ainda não foi esclarecido se estes organismos persistentes realmente formam um subgrupo (de fenótipo definido de fato), com propriedades observáveis claramente distintas de outras de mesma espécie, ou se simplesmente constituem na fração mais resistente da distribuição de população daquela espécie naquele momento (que eventualmente sobrevive às intempéries externas àquele biofilme). 


\subsection{A AQUISIÇÃO DE RESISTÊNCIA A ANTIBIÓTICOS}

É importante enfatizar que nem toda bactéria é patogênica (causadora de doença infecciosa). Por exemplo, há várias bactérias simbiontes dentro de nós que são fundamentais para a nossa saúde. ${ }^{14}$ Algumas delas produzem substâncias químicas importantes que nós não produzimos.14-15 Já outras, pelo simples fato de existirem, competem por nutrientes com as eventuais bactérias patogênicas. Então somente uma parte dos microrganismos (MOs) é capaz de nos causar doenças, ${ }^{1,14-15}$ Assim, um ambiente que tem uma diversidade microbiana altíssima pode ser até mais seguro devido à competição por nutrientes entre os MO patogênicos e não patogênicos. Em um ambiente hospitalar, infelizmente, acontece justamente o contrário. ${ }^{16} \mathrm{O}$ uso dos mesmos antibióticos diminui a diversidade microbiana do paciente e, pelo fato de o hospital ser um local sempre visitado por humanos infectados, alguns desses patógenos acabam adquirindo resistência. A aquisição de resistência pode ocorrer por quatro maneiras principais: mutação, conjugação, transdução viral e transformação.

A primeira delas, a mutação benéfica para o MO, é um evento raríssimo. É muito mais provável uma mutação originar um malefício ao indivíduo do que um benefício. Contudo, em se tratando da evolução, o processo mutagênico é essencial para a adaptação de toda uma espécie em novos ambientes. Inclusive, quando lidamos com procariotos, estamos diante do número astronômico de microrganismos. Estima-se que só o corpo humano seja habitado por cerca de $10^{14}$ bactérias (isto é, 100 trilhões de bactérias) de aproximadamente 200 tipos diferentes. ${ }^{15,17}$ Além disso, as diferenças genéticas dentro de uma única espécie bacteriana são exorbitantes: diferentes cepas de Escherichia coli, por exemplo, podem ter mais de $25 \%$ de seus genomas diferindo entre si. ${ }^{1}$ Ademais, as taxas de replicação de bactérias são altíssimas: algumas chegam a se duplicar em 20 minutos. ${ }^{18-19}$ Logo, eventualmente ocorre uma alteração genética benéfica em uma determinada bactéria patogênica. É, portanto, razoável imaginar que seja possível aparecer em um hospital pelo menos uma bactéria patogênica capaz de suportar uma mutação e que esta mutação ainda lhe trouxesse os benefícios de se defender dos antibióticos usados naquele hospital. 0 problema é que a aquisição de resistência a antibióticos por parte dos MOs hospitalares não depende somente da ocorrência deste evento raríssimo. Fenômenos de Transferência Horizontal de Genes como Conjugação, Transdução Viral e Transformação podem distribuir a capacidade de 
resistência a antibióticos adquirida por uma única célula para quaisquer outras células no ambiente. Às vezes, uma bactéria não patogênica adquire o gene de resistência e o transfere para uma bactéria patogênica por um destes três processos.

FIGURA 04 - MECANISMOS DE AQUISIÇÃO DE RESISTÊNCIA A ANTIBIÓTICOS. Três processos de transferência de genes (pedaços de fita de DNA). Se um gene induz um processo bioquímico que protege a bactéria contra a ação de antibióticos, então este gene é um gene de resistência (pedaço de fita vermelha). Por outro lado, genes quaisquer são ilustrados por pedaços de fitas de cor amarela. O gene de resistência pode estar tanto no DNA genômico (fita grande e emaranhada, que contém os genes principais da bactéria), quanto no DNA plasmidial (fita circular pequena, que contém genes auxiliares). Ao centro, ilustramos uma bactéria não resistente a um antibiótico (fitas amarelas) que pode adquirir um gene de resistência externo (pedaço de fita vermelha). (a) Processo de Conjugação Bacteriana, em que o gene de resistência (vermelho) está dentro do DNA plasmidial (fita de DNA circular) e este é transferido por meio de um canal proteico chamado Pilus. (b) Processo de Transdução Viral, em que um vírus infecta uma bactéria já resistente a antibióticos e seu DNA se mistura com o DNA da bactéria. Durante a etapa de multiplicação viral, espalham-se vírus com genes de resistência. (c) Processo de Transformação bacteriana, em que a bactéria incorpora um DNA solto no ambiente. ${ }^{20-24}$

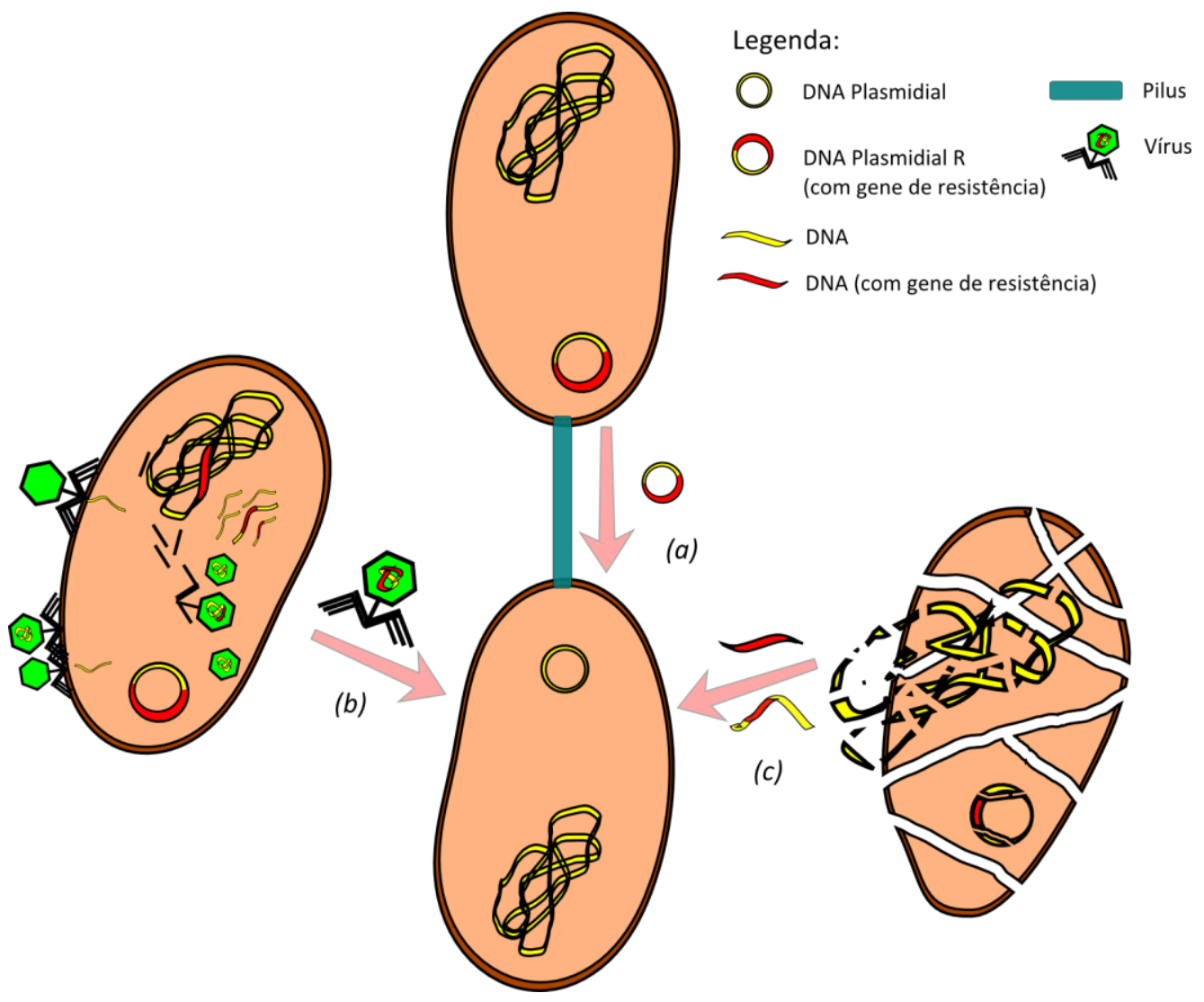

Fonte: Elaborada pelo autor.

O processo de Conjugação Bacteriana é a transferência do DNA Plasmidial de uma bactéria a outra por meio do Pilus, um canal proteico que conectando ambas as células (FIGURA 04.a). Os plasmídeos são pequenas moléculas de DNA circular que podem se 
replicar independentemente do genoma. Se um plasmídeo tem um gene que confere resistência a um determinado antibiótico, ele pode ser duplicado e transferido para outra bactéria nas vizinhanças (não necessariamente da mesma espécie) por meio de conjugação. ${ }^{20,22}$

O processo de Transdução Viral é a transferência de uma sequência de DNA de uma bactéria a outra por intermédio de um vírus (exemplo: bacteriófago) (FIGURA 04.b). ${ }^{20,23}$ Vírus são parasitas intracelulares obrigatórios constituídos por um capsídeo (cápsula proteica, podendo ter um revestimento molecular extra) que carrega material genético (RNA e/ou DNA) em seu interior. Fora de uma célula hospedeira, os vírus não apresentam atividade metabólica. Como eles não tem tal autonomia metabólica, os vírus não são considerados seres vivos. Entretanto, quando eles infectam uma célula, o material genético liberado no interior do hospedeiro é lido pela maquinaria deste, que pode passar a produzir várias cópias virais. 0 material genético viral pode ser muito simples, contendo apenas 3 genes, ou relativamente complexo, com até centenas de genes. ${ }^{1}$ Durante o processo de infecção viral, os genes virais são intercalados no material genético do hospedeiro. Assim, quando ocorre a multiplicação viral, é possível que um gene de resistência a antibióticos da bactéria hospedeira seja copiado junto com o patrimônio genético viral. Consequentemente, quando tais vírus entram no Ciclo Lítico (de alta atividade metabólica, em que o número de partículas virais produzidas no hospedeiro chega a ser tão grande que causa a lise celular), esses novos vírus produzidos são liberados para o ambiente, podendo infectar outras bactérias e transferir seu patrimônio genético (com o gene de resistência) para novas células hospedeiras. Não necessariamente quando um vírus infecta uma célula ele desencadeia o seu Ciclo Lítico. 0 material genético viral pode permanecer incorporado no do hospedeiro sem ser (drasticamente) ativado, de modo que podem existir bactérias hospedeiras com gene de resistência recentemente adquirido por Transdução Viral se proliferando no ambiente.

O processo de Transformação é talvez o mais simples e, por esta razão, extremamente preocupante. ${ }^{24}$ Transformação é o processo de uma bactéria incorporar um material genético que estava livre no ambiente (FIGURA 04.c). Em um hospital, por exemplo, usam-se muitos produtos químicos que visam à limpeza e à esterilização do ambiente. De fato, incontáveis microrganismos são mortos todos os dias. 0 problema é que o conteúdo intracelular destes é frequentemente liberado para o meio ambiente. 
Logo, nada impede que os pedaços de DNA liberados no ambiente contenham sequências de gene de resistência a antibióticos, que eventualmente possam ser absorvidas por outras bactérias naquele local.

\subsection{ANTIMICROBIANOS POLIMÉRICOS}

Após vários anos, a comunidade científica percebeu que a baixa massa molecular conferia uma série de desvantagens aos antibióticos tracionais. Por exemplo, compostos pequenos tem um curto tempo de ação e, geralmente, são tóxicos quando um excesso do composto é utilizado. ${ }^{25}$ Esses problemas são atenuados quando se usa polímeros antimicrobianos. ${ }^{25-29}$ Os polímeros, como o próprio nome diz: poli (do grego, muitos) e meros (do grego, partes), são macromoléculas (da ordem de $10.000 \mathrm{~g} / \mathrm{mol}$ ou mais) formadas pela repetição consecutiva dos monômeros (unidades fundamentais). Por formarem uma classe muito diversa, eles são divididos em uma série de subclasses. Se um polímero contém carga elétrica em sua cadeia quando solubilizado, ele é denominado polieletrólito e pode ser classificado como positivo (catiônico) (TABELA 02.a), negativo (aniônico) (TABELA 02.b) ou zwitteriônico (com ambas as cargas) (TABELA 02.c). Polieletrólitos são em geral solúveis em água e, por conseguinte, podem ser administrados por via oral (como transportador de medicamentos) ou serem utilizados no ambiente, por exemplo, para o tratamento de água. ${ }^{25}$ Há polímeros que podem ter em sua cadeia principal átomos de carbono conectados por ligações simplesdupla, denominados polímeros conjugados (TABELA 02.d), e aqueles que não, ditos polímeros não conjugados (TABELA 02.e). 
TABELA 02 - CLASSIFICAÇÃO POLIMÉRICA. Os asteriscos (*) indicam que o polímero é antimicrobiano.

\begin{tabular}{|c|c|c|c|c|}
\hline \multicolumn{3}{|c|}{ Polieletrólitos (Polímeros Carregados) } & \multicolumn{2}{|c|}{ De cadeia principal } \\
\hline [a] & [b] & [c] & [d] & [e] \\
\hline Catiônicos (+) & Aniônicos (-) & Zwitteriônicos ( \pm ) & Conjugada & Saturada \\
\hline $\mathrm{NH}_{3}^{+}$ & $\mathrm{SO}_{3}^{-} \mathrm{Na}^{+}$ & $\cos ^{-}$ & & $\mathrm{OH}$ \\
\hline $\begin{array}{l}\text { Poli(hidrocloreto de } \\
\text { alilamina) }\end{array}$ & $\begin{array}{c}\text { Poli(estireno } \\
\text { sulfonato de sódio) }\end{array}$ & $\begin{array}{l}\text { Poli(metacrilato de } \\
\text { carboxibetaína) }\end{array}$ & $\begin{array}{l}\text { Poli(p-fenileno } \\
\text { vinileno) }\end{array}$ & Poli(4-vinilfenol) \\
\hline PAH & PSS & CBMA & PPV & PVPh \\
\hline * & * & * & - & * \\
\hline
\end{tabular}

Fonte: [a] IARIKOV et $\mathrm{al}^{29} ;[b, c, e]$ MUÑOZ-BONILLA; FERNÁNDEZ-GARCÍ $A^{27}$. [d] MARLETTA et $\left.a\right|^{30}$.

\subsection{ESTRATÉGIAS PROMISSORAS DE COMBATE A MICRORGANISMOS}

Nas últimas décadas, alguns peptídeos antimicrobianos (antimicrobial peptides, AMPs) ganharam destaque. Alguns deles, em especial, conseguem agir diretamente nas membranas bacterianas. ${ }^{31-36}$ Logo, esses antibióticos não precisam atravessar tais barreiras, se acumular dentro da célula e aí achar o seu alvo. Entretanto, apesar de haver várias vantagens dessa classe de antibióticos, os AMPs tem uma série de desvantagens: são muito caros de serem sintetizados ou isolados; ${ }^{32-33}$ são materiais fisicamente e quimicamente instáveis; ${ }^{33-34}$ não podem ser administrados oralmente; ${ }^{32}$ não podem ser usados em altas concentrações (têm uma eficácia limitada pela toxicidade); ${ }^{25}$ e têm pouca distribuição nos tecidos. ${ }^{26}$ Ademais, a falta de consenso sobre o mecanismo de ação deles é um grande problema. ${ }^{32,35-36}$ É bem aceito na literatura que a primeira interação de AMPs em membranas é guiada por interações eletrostáticas. Entretanto, acredita-se que tais interações não sejam suficientes a ponto de causar morte bacteriana. Logo, seriam necessárias etapas subsequentes guiadas por outros tipos de interação (hidrofóbica, ligações de hidrogênio, etc) ${ }^{26,32}$ A comunidade científica pesquisa intensamente esse tema há 30 anos e, embora existam raríssimas exceções, o mecanismo molecular de ação antimicrobiana é ainda controverso.32-36 A falta de informação da relação entre estrutura-atividade dos AMPs limita a descoberta racional 
de novos fármacos desta classe $32,35-36$ - dificultando a luta contra as bactérias já resistentes a alguns desses AMPs. ${ }^{35}$

Por mais que se tenha conhecimento dos mecanismos de resistência contra cada antibiótico, a grande maioria deles atua em um único alvo específico (podendo ser uma enzima vital, uma proteína estrutural ou até mesmo uma proteína de sinalização na biomembrana bacteriana). ${ }^{25}$ Qualquer alteração ou desvio deste alvo pode gerar um novo mecanismo de resistência. ${ }^{7-12}$ Neste sentido, técnicas chamadas de Inativação Fotodinâmica (IFD) têm tido destaque. ${ }^{37-39}$ A Inativação Fotodinâmica é uma estratégia promissora por produzir moléculas peróxido de hidrogênio ou radicais livres altamente reativos que atacam (oxidam) randomicamente diversas partes dos patógenos de uma só vez. ${ }^{37}$ Tais radicais livres são Espécies Reativas de Oxigênio (EROs) produzidas quando uma molécula especial chamada Fotossensibilizador (FS) absorve fótons característicos ( $\lambda$ de excitação) e transfere essa energia para as moléculas da vizinhança (sobretudo oxigênio molecular). Tais EROs oxidam toda a vizinhança do FS que fora excitado (cerca de 10Å). ${ }^{39}$ Ou seja, há radicais livres somente em torno dos FS que absorvem aquele comprimento de onda de excitação. Logo, se a posição em que os FSs estão é conhecida, é só ter uma fibra ótica e iluminar aquela região para a produção de radicais livres se iniciar. As desvantagens desta técnica são: ${ }^{39-40}$ (1) nem sempre os FSs se acumulam o suficiente aonde queremos (em torno dos MOs); (2) nada impede que a os radicais produzidos possam atacar também células humanas. Logo, o FS a ser utilizado tem que ter sua dosagem e toxicidade muito bem caracterizada para cada patógeno e para cada órgão infectado; (3) é uma técnica pouco viável de ser utilizada em uma infecção nas entranhas do paciente; (4) os fotossensibilizadores não são moléculas poliméricas, logo trazem consigo todas as limitações de antimicrobianos de baixa massa molecular - especialmente a instabilidade química. ${ }^{25,40}$

Uma alternativa para melhorar o desempenho da ação de compostos antimicrobianos e/ou de moléculas fotossensibilizadoras é o uso de estratégias de Drug Delivery (Entrega do Medicamento). Drug Delivery é um tema científico em alta nas últimas décadas. ${ }^{41-43}$ Brevemente falando, trata-se de misturar diferentes moléculas com o medicamento visando ter um controle maior da entrega deste ao alvo de interesse. Parâmetros como seletividade, taxa de liberação do princípio ativo e tempo de vida deste dentro do nosso corpo são frequentemente melhorados. ${ }^{41,43}$ Tipicamente, 
encapsula-se o princípio ativo. As propriedades físico-químicas da cápsula é que melhoram a entrega do medicamento. A composição e a estrutura destas cápsulas variam muito a cada caso. Inclusive, o medicamento pode ficar dentro ou fora da cápsula carregadora. Tais carregadores podem ser lipossomos, polímeros, dendrímeros, nanotubos de carbono, metais, etc, ou uma mistura destes, que geralmente traz resultados promissores. ${ }^{42}$ Neste sentido, acreditamos que se o próprio carregador fosse constituído de um material antimicrobiano, como a quitosana, o efeito antimicrobiano seria amplificado.

\subsection{MODOS DE PERTURBAÇÃO DE MEMBRANAS}

Aqui, listamos os principais modos de ação antimicrobiana em membranas. ${ }^{26,31--36}$ FIGURA 05 - PRINCIPAIS MECANISMOS INTERAÇÃO COM MEMBRANAS. Todos esses mecanismos são baseados em estudos com AMPs. (a) Primeira etapa de interação: Ligação. (b-g) Possíveis segundas etapas de interação. (b) Mudança na Conformação Molecular (tradução literal): os AMPs poderiam induzir mudança de fase dos lipídeos da membrana; (c) Formação de Poros tipo Barril: interações peptído-peptídeo formam uma estrutura análoga à parede de um barril, permitindo que metabólitos atravessem a bicamada descontroladamente. Neste caso, o poro é constituído somente por peptídeos; (d) Formação de Poros tipo Toroidal: os AMPs dobram o folheto lipídico externo fundindo-os com o folheto interno, gerando um poro toroidal (como uma rosquinha) na bicamada. Neste caso, o poro é constituído por peptídeos e lipídeos; (e) Afundamento de Domínios (tradução literal): modelo em que os AMPs penetram na membrana formando pequenos agrupamentos de lipídeo-proteína ( rafts), que são transferidos (afundados) para o outro folheto lipídico (interno). Neste modelo, uma pequena concentração de peptídeos é suficiente para causar tal perturbação. (f) Modelos tipo Carpete: uma grande quantidade de AMPs (acima de um limiar) é necessária para desencadear efeito antibacteriano, que pode ser de dois tipos: (f.1) solubilização da membrana para o meio aquoso por Efeito Detergente, devido à formação de micelas ou por (f.2) Atividade Interfacial, que propicia a criação de defeitos no ordenamento lipídico, levando a um rearranjo dos grupos polares e hidrofóbicos dos lipídeos da membrana. Tal desordem conformacional dos lipídeos causada pelos AMPs seria o fator responsável pela mudança na permeabilidade da membrana; $(g$ ) indução de Agrupamento Lipídico: AMPs eventualmente poderiam agregar tipos lipídicos semelhantes, fazendo com que estes não se distribuíssem de maneira natural na membrana. As bordas desses agrupamentos formam defeitos dos quais vazariam metabólitos.

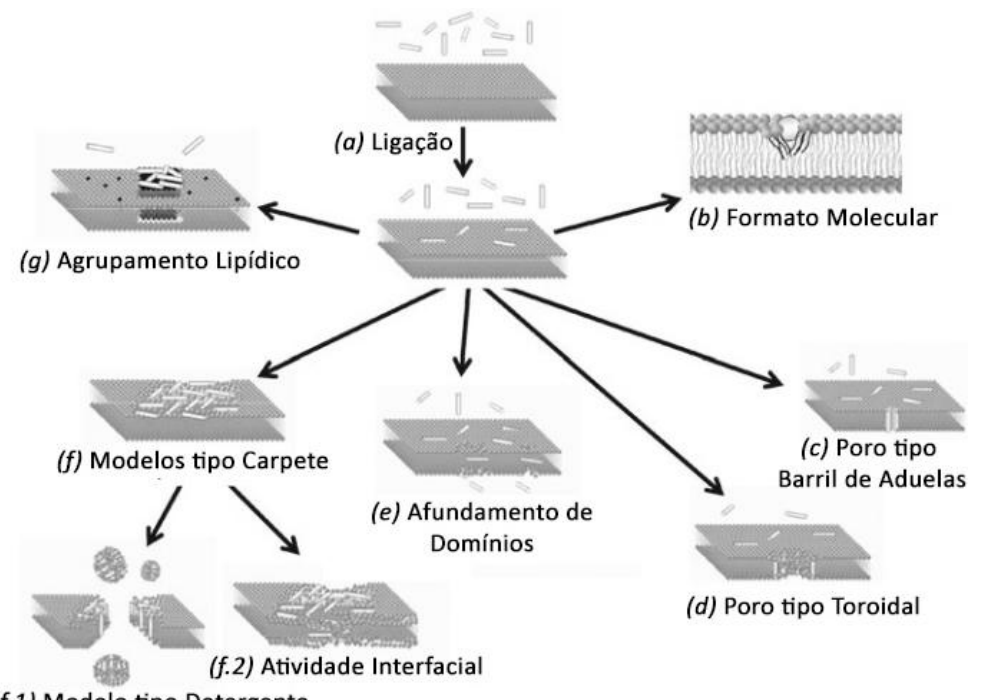

(f.1) Modelo tipo Detergente

Fonte: adaptada de WIMLEY, W. C.; HRISTOVA, K. ${ }^{32}$ 


\section{MOTIVAÇÃo}

Em particular, o polímero de Quitosana vem ganhando muito destaque por ter um conjunto notável de propriedades: é extremamente biocompatível, atóxico, barato, estável (quimicamente; termicamente), versátil quimicamente (fácil de criar novos derivados a partir dele), antifúngico e antibacteriano (inclusive de cepas multirresistentes). ${ }^{44-50}$ Além disso, recentemente, pesquisas mostraram sua capacidade de combater biofilmes bacterianos e fúngicos. ${ }^{11,47-50}$ Uma limitação bastante conhecida dos polímeros de quitosana (sobretudo os de alta massa molecular) é que eles são

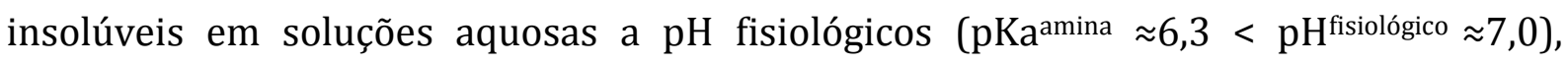
tornando restrita a sua aplicação somente para soluções que tenham pHs mais ácidos $\left(\mathrm{pH}^{\text {ácido }}<6,0\right)$, em que seus grupos amina ficam protonados $\left(\mathrm{NH}_{2} \rightarrow\left(\mathrm{NH}_{3}\right)^{+}\right)$, conferindo uma carga positiva ao polímero. ${ }^{44-46}$ Contudo, já há grupos de pesquisa que estão tentando aumentar a solubilidade de quitosanas em pHs neutros. ${ }^{45,51-52}$ Uma maneira é fazer modificações químicas na quitosana, garantindo uma carga positiva permanente, independentemente do $\mathrm{pH}$ do meio. ${ }^{45,52-53}$ Outra maneira é diminuir a massa molar do polímero, visto que oligômeros de quitosana possuem uma boa solubilidade a $\mathrm{pH}$ fisiológico. Finalmente, uma possibilidade interessante é adicionar outros compostos na solução. Por exemplo, a adição de trifosfato de sódio polianiônico (TPP) em nanopartículas de quitosana consegue estabilizá-las em pH neutro, sendo até eficazes contra biofilmes bacterianos de Streptococcus mutans. ${ }^{50}$ Logo, acreditamos que quitosanas e/ou seus derivados poderão ser excelentes transportadores de compostos antimicrobianos, capazes de combater diferentes tipos de biofilmes bacterianos. Em particular, a estratégia de usar nanopartículas de quitosana como veículo de entrega de fotossensibilizadores (FS) poderia ser uma das mais promissoras no combate de biofilmes bacterianos e de microrganismos resistentes a antibióticos. Uma vez que o ataque dos radicais livres por parte dos FS não tem um único alvo em específico e a quitosana já é antimicrobiana e biocompatível, tal estratégia antimicrobiana pode ser extremamente promissora. ${ }^{11}$ Além das quitosanas poderem ser usadas em estratégias de remediação, elas também poderiam ser utilizadas em estratégias preventivas, pois são macromoléculas estáveis no ambiente. ${ }^{25}$ Por exemplo, polímeros são materiais que podem formar fibras para elaboração de tecidos, como também películas protetoras que revestem materiais. Inclusive, já existem polímeros antimicrobianos que são utilizados 
em bandagens médicas e em películas que recobrem o interior de caixas de suco (visando aumentar o tempo de prateleira destes produtos). ${ }^{25}$ Além disso, como a quitosana é uma macromolécula anfifílica (com regiões hidrofílicas e hidrofóbicas na mesma) de baixo custo, seria possível usá-la para o tratamento de água em larga escala.44-46 Não obstante, apesar de haver inúmeras evidências de sua capacidade antimicrobiana, o mecanismo geral de ação das quitosanas é ainda muito discutido e controverso. ${ }^{46,53-55}$ Dentre os principais mecanismos propostos, aquele que é mais aceito pela literatura é que a quitosana desestabiliza as biomembranas dos microrganismos. ${ }^{55-56}$ Entretanto, o entendimento das interações de quitosanas com membranas biológicas ou com membranas modelos é um tópico ainda pouco explorado do ponto de vista molecular - cujo estado da arte é descrito na próxima subseção. ${ }^{55-65} \mathrm{De}$ fato, é aqui que esta pesquisa de mestrado se insere.

Entender como (e quais) são as interações em nível molecular entre compostos antimicrobianos e membranas modelo é um passo fundamental para tentar determinar como (e quanto) as estruturas químicas destes antibióticos afetam/perturbam as membranas biológicas. Isto é, em longo prazo, queremos determinar quais são as relações entre estrutura química do antibiótico com a sua atividade antimicrobiana. Atualmente, tais relações são desconhecidas para a grande maioria dos antimicrobianos que agem em membranas - o que é um enorme empecilho para o desenvolvimento de novos compostos. Brevemente, o cenário científico atual "desenvolve" (de fato, descobre) novas moléculas antimicrobianas por experimentos tipo tentativa e erro. Se conhecêssemos como são as relações entre estrutura e atividade (REAs), poderíamos criar novos fármacos de forma racional (planejada). Desta forma, seríamos mais eficientes ao combater microrganismos resistentes.

A falta de informações em nível molecular da interação de quitosana com membranas se deve a vários fatores. Primeiro, o termo "quitosana" é um termo bastante ambíguo do ponto de vista de estrutura molecular. Ele se refere a um tipo de molécula que tem vários parâmetros importantes que podem variar muito e, consequentemente, ter diferentes mecanismos de ação. Quitosana é o nome dado às moléculas resultantes da Reação de Desacetilação de Quitina (FIGURA 06). 
FIGURA 06 - REAÇÃO DE SÍNTESE DE QUITOSANA. A Reação de desacetilação de quitina é feita por adição de uma base forte (e.g., $\mathrm{NaOH})$ a altas temperaturas $\left(\approx 100^{\circ} \mathrm{C}\right)$. Legenda: "Ac" é grupo acetil, " $1-\mathrm{X}^{\prime}$ é a fração de unidades de glicosamina (GlicN, que pode ter carga positiva se protonada) e " $X$ " é a fração de $\mathrm{N}$-acetilglicosamina (NAG).

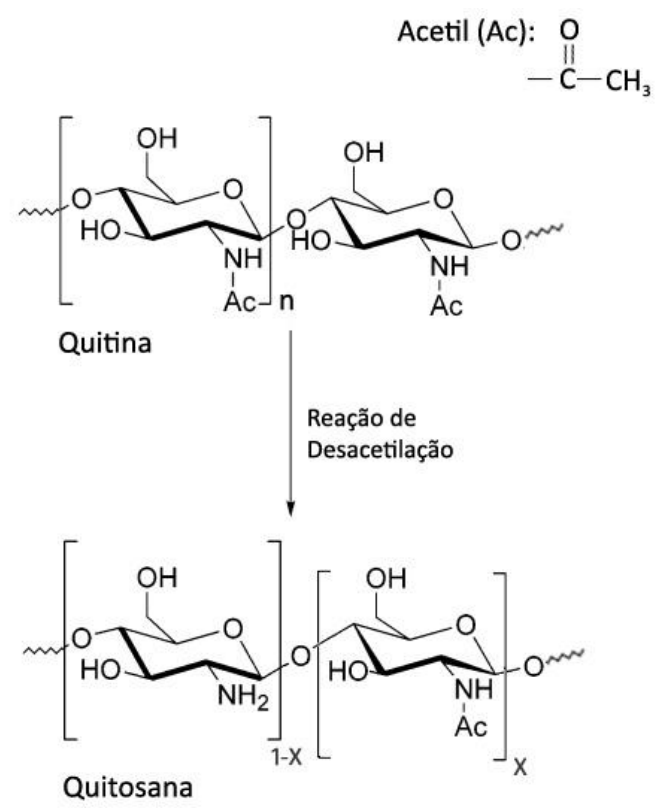

Fonte: Adaptada de GOY; DE BRITTO; ASSIS. ${ }^{46}$

A Quitina é o principal polímero estrutural de exoesqueletos de invertebrados (crustáceos, insetos e aranhas) e é também um dos componentes mais abundantes das paredes celulares de fungos e de algas. ${ }^{66}$ Para fins industriais, ele geralmente é extraído da casca de camarões e de outros frutos do mar que antes eram jogados no lixo. ${ }^{54}$ Portanto, é uma fonte renovável extremamente barata. ${ }^{45-46,54}$ Então, o termo "quitosana" se refere aos copolímeros cujos monômeros são os da quitina precursora (unidades de $\mathrm{N}$-acetilglicosamina, NAG) e os da quitina desacetilada (unidades de Glicosamina, GlicN). Logo, um parâmetro muito importante das quitosanas é o seu Grau de Desacetilação (GD), que mede a fração unidades de glicosaminas naquele copolímero. ${ }^{44-46}$ Em outras palavras, também poderíamos medir o parâmetro oposto: o Grau de Acetilação (GA) da quitosana, que informa a fração de quitina (precursor) que ainda resta no copolímero de quitosana. Outros parâmetros importantes são: massa molecular média (Mw) do copolímero, a polidispersividade (a largura da distruibuição de Mw), grau de protonação do grupo amina nas unidades de GlicN (que depende do $\mathrm{pH}$ da solução e da Mw do polímero), em que tipo de solução ela está, etc. 
Um segundo fator que dificulta a pesquisa com membranas é a própria complexidade do sistema. Membranas biológicas são estruturas dinâmicas muito complexas, compostas por uma diversidade de lipídeos, proteínas, sacarídeos e têm uma rede de filamentos (geralmente actina) sustentando a sua estrutura por dentro da célula. ${ }^{1,67}$ Dependendo do organismo ou do ambiente químico que este se insere, a célula é capaz de fazer alterações tanto no seu formato, quanto na composição química destas membranas. Então, a investigação de membranas biológicas é uma tarefa extremamente complexa, tendo uma infinidade de parâmetros relevantes conhecidos e desconhecidos e, portanto, de difícil controle experimental. Para facilitar, usam-se modelos de membranas. ${ }^{68}$ Os modelos mais populares existentes são: Filmes de Langmuir (monocamadas lipídicas planas na subfase líquida), Filmes de LangmuirBlodgett (bicamadas lipídicas planas afixadas/sustentadas em substrato sólido) e Lipossomos (bicamadas lipídicas esféricas em um líquido). Um breve detalhamento sobre esses modelos será discutido mais na seção teórica, mas convidamos o leitor a ponderar a respeito do grau de simplificação desses modelos em relação à membrana do MO.

Além de todos esses fatores listados, um terceiro fator que justifica a escassez de pesquisa de interações de compostos com membranas é que há pouquíssimas técnicas que são capazes de investigar sem/com poucas ambiguidades tais interações do ponto de vista molecular.68 Membranas são estruturas nanométricas que separam dois ambientes volumosos (regiões do interior da matéria, bulk). Coletar sinal somente da interface sem a interferência de compostos presentes no volume da amostra é um desafio. Talvez a técnica mais adequada para detectar sinais de interações moleculares intrinsecamente interfaciais em uma superfície líquida é a Espectroscopia SFG a Espectroscopia Vibracional Não Linear de Interfaces por Geração de Soma de Frequências (Sum-Frequency Generation, SFG). Em particular, a Espectroscopia SFG é a capaz de detectar interações moleculares exclusivamente interfaciais das moléculas de água. Os detalhes da Espectroscopia SFG serão descritos na seção teórica. 


\subsection{O ESTADO DA ARTE (QUITOSANAS EM MODELOS DE MEMBRANA)}

Considerando a importância e alto apelo científico e tecnológico das quitosanas, há de fato muitos artigos de revisão na literatura que descrevem o(s) seu(s) mecanismo(s) de ação antimicrobiana, ${ }^{46,53-56}$ mas são poucos os trabalhos que de fato adicionam alguma informação em nível molecular.51-52,56-65 A literatura sugere que as quitosanas e seus derivados podem afetar de diversas maneiras as bactérias. ${ }^{53-56}$ Alguns derivados de quitosanas, por exemplo, são considerados bacteriostáticos (inibem o crescimento bacteriano), enquanto outros são considerados bactericidas (causam a morte da bactéria).53-54 Há relatos que quitosanas são capazes de romper as biomembranas, liberando constituintes intracelulares para o meio extracelular,53-56 principalmente de bactérias Gram-Positivas durante a divisão celular. ${ }^{56}$ Em baixas concentrações, estudos sugerem que as quitosanas poderiam causar aglutinação lipídica ao interagir com as cargas negativas das membranas; em altas concentrações seriam capazes de alterar drasticamente o potencial de membrana. 53-58,60-62 Quitosanas alteram a permeabilidade seletiva das membranas (capacidade de controle de entrada e saída de constituintes da célula) ao interagir com elas (perturbando-as) ou eventualmente aprisionando algumas moléculas de água interfaciais em seu entorno. ${ }^{53-55}$ Além disso, poderiam atuar como agentes quelantes, que seletivamente se ligariam a íons metálicos importantes nas vizinhanças das células. ${ }^{53-55}$ Quitosanas e seus derivados, por serem polímeros catiônicos, seriam capazes de interagir com o DNA (que tem grupos fosfatos aniônicos), com algumas enzimas (inibindo-as). ${ }^{53-55}$ RAFAAT et al. analisaram as mudanças na expressão gênica de bactérias gram-positivas (Staphylococcus simulans e Staphylococcus aureus) na presença de quitosanas $(50.000 \mathrm{~g} / \mathrm{mol}<\mathrm{Mw}<190.000 \mathrm{~g} / \mathrm{mol}$, cujo GD entre 70-85\%; solução de ácido acético (1\%). Eles mostram que quitosanas são capazes de desencadear uma drástica mudança nos processos metabólicos desses microrganismos, ativando vários processos de defesa - o que afetaria diretamente na taxa de crescimento bacteriano ${ }^{53}$. Neste trabalho, inclusive, há evidências de que a presença de quitosana causou a regulação (ativação/desativação) de genes associados a processos de (i) controle de stress osmótico, (ii) metabolismo energético e (iii) reciclagem da parede celular e seus constituintes. Ademais, eles mostram que a presença de quitosanas causa a liberação de íons potássio intracelular e que o potencial de membrana é reduzido. Inclusive, em alguns casos, imagens de microscopia de transmissão mostraram que as bactérias formaram estruturas intracelulares 
semelhantes aos vacúolos das plantas sob situação de estresse osmótico para evitar autólise. ${ }^{53}$ Já do ponto de vista de metabolismo energético, RAFAAT et al. sugerem que, como as membranas celulares são uma das principais estruturas para a geração de ATP via metabolismo aeróbico (alta produtividade), as quitosanas consequentemente também perturbariam a principal fonte de produção de energia das bactérias. Tal hipótese é embasada na ativação da expressão de genes de metabolismo anaeróbico (rota bioquímica de fermentação, de baixa produtividade de ATP na presença de quitosana), em que seria uma alternativa para a produção de energia (no citoplasma) tendo em vista o dano que a quitosana teria causado na cadeia transportadora de elétrons da membrana (inibição da atividade de enzimas de óxido-redução da via do metabolismo aeróbico).

Considerando o principal mecanismo de ação antimicrobiana aceito na literatura (agentes perturbadores de membranas) ${ }^{53-55}$, acredita-se que, do ponto de vista molecular, o processo de interação deve ocorrer em mais de uma etapa. ${ }^{55}$, 62 É consenso que a primeira etapa de interação seja predominantemente devido a interações eletrostáticas ${ }^{55-65}$. Tais interações seriam entre os grupos catiônicos de amina protonada $\left(-\mathrm{NH}_{3}\right)^{+}$das quitosanas com as cargas negativas presentes nas membranas bacterianas sobretudo com os grupos fosfatos aniônicos $\left(-\mathrm{PO}_{4}\right)^{-2}$ dos lipídeos ou ácidos teicóicos bacterianos que ficam expostos ao ambiente extracelular ${ }^{55-56}$. Logo, por terem cargas opostas, tais interações de longo alcance atrairiam as quitosanas às membranas bacterianas. Mais do que isso, uma vez que as membranas plasmáticas de mamíferos são, em geral, predominantemente zwitteriônicas (carga resultante nula, sobretudo no folheto externo exposto ao meio extracelular), acredita-se que é justamente esta primeira etapa de interação que seja responsável pela sua seletividade. Isto é, provavelmente as interações eletrostáticas seriam responsáveis pelo fato de as quitosanas serem biocompatíveis com células humanas (não tóxico às nossas células) ao

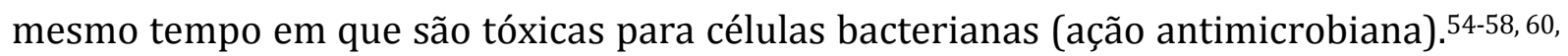
63-65 Embora seja evidente a importância das interações eletrostáticas para a interação de quitosanas com membranas, um trabalho desenvolvido no nosso grupo, o Grupo de Polímeros "Bernhard Gross" do IFSC/USP, mostrou que elas por si só não deveriam ser suficientes para ter efeito antimicrobiano. 60 Nele, comparou-se o efeito de dois polieletrólitos catiônicos: o poli(hidrocloreto de alilamina)(PAH, Mw=15.000 g/mol) e 
Quitosanas de baixa massa molecular (LMWCh, Mw=113.000 g/mol; GD = 78\%) em monocamadas lipídicas de DPPC $( \pm)$ e de DPPG(-) em subfase de tampão TS (TheorellStenhagen) a pH 3,0. O PAH é um polieletólito catiônico que tem uma amina protonável em pHs ácidos (totalmente protonada abaixo de $\mathrm{pH}=6,0$ ) como a quitosana. Por ter pouco caráter hidrofóbico, o PAH idealmente representaria um polímero que interage somente eletrostaticamente com as monocamadas de Langmuir. Assim, observou-se que o PAH perturbou muito pouco ambas as membranas em comparação às quitosanas. Portanto as etapas de interação subsequentes das quitosanas seriam não eletrostáticas. Estas interações são menos exploradas do ponto de vista molecular e que provavelmente causariam a perturbação mais drástica das membranas bacterianas. Assim, diferentes interações de curto alcance, como interações hidrofóbicas, interações de van der Walls e até mesmo ligações de hidrogênio devem mediar a morte bacteriana. Um trabalho posterior de um grupo da Polônia que investigou diferentes soluções de

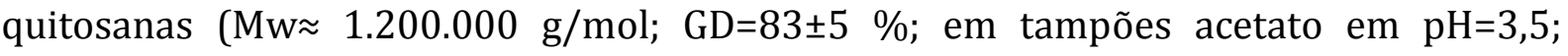
$\mathrm{pH}=4,75$; e $\mathrm{pH}=6,0$ ) interagindo com filmes de Langmuir de DPPG (lipídio aniônico) também suporta tal tendência. ${ }^{64}$ Infelizmente, os detalhes destas interações são ainda um problema em aberto, com pouquíssimos trabalhos publicados. ${ }^{55-65} \mathrm{Um}$ trabalho feito por LIU et al. de espectroscopia vibracional FTIR em diferentes misturas de soluções de quitosanas (Mw $\approx 78.000 \mathrm{~g} / \mathrm{mol}$; GD=85,5\%; em acetato) com dispersões de Lipossomos de PC (lipídio zwitteriônico, em tampão de sal de fosfato, PBS) sugere que é o grupo fosforil, e não a carbonila da cabeça polar dos lipídeos (PC) que participa da interação com o grupo $\mathrm{NH}_{3}{ }^{+}$das quitosanas. ${ }^{56}$ Entretanto, não há indicativos de que tais mudanças espectrais sejam devidas aos grupos fosforil do lipossomo ou a um artefato gerado pelos grupos fosfato do tampão.

Neste sentido, nosso grupo e um grupo da Polônia proporcionaram os principais avanços na investigação das interações de soluções de quitosanas com modelos de membrana do tipo Filmes de Langmuir e Langmuir-Blodgett (LB). 57-65 Sabe-se que soluções diluídas de quitosana na subfase (de $0,05 \mathrm{~g} / \mathrm{L} \mathrm{a} 0,2 \mathrm{~g} / \mathrm{L}$ ) dentro do faixa de pHs entre 3,5 a 6,0 não têm atividade surfactante, que tipicamente está relacionada a efeitos de viscosidade do polímero. ${ }^{57,63}$ Entretanto, estudos mostram que quitosanas adsorvem na interface líquido-ar na presença de Filmes de Langmuir de lipídios aniônicos(DMPA ou DPPG), 57-59, 63-64 zwitteriônicos (DPPC) 57, 60, 65 e neutros (colesterol).62-63, 65 Nesses estudos, as maiores perturbações causadas pela quitosana foram nos modelos de 
membranas de lipídios aniônicos, que simulam as biomembranas bacterianas. ${ }^{57,63}$ KRAJEWSKA et al. mostraram que, na ausência de quitosana, o grau de fluidez de filmes de Langmuir de DPPG(-) é muito mais sensível ao pH da subfase de tampão acetato (pH entre 3,5 a 6,0) do que o de filmes de $\operatorname{DPPC}( \pm)$ e o de colesterol (neutro). ${ }^{63}$ Monocamadas de DPPG(-) em tampão sem quitosana se tornam mais expandidas e fluídas (no plano da interface) conforme se aumenta o $\mathrm{pH}$ (valores próximos ao de 6,0). Em contrapartida, filmes de colesterol ficam ligeiramente mais enrijecidos. Já monocamadas de $\operatorname{DPPC}( \pm)$ são praticamente independentes do $\mathrm{pH}$ do tampão, inclusive na presença de quitosana na subfase $(\mathrm{Mw}=1.200 .000 \mathrm{~g} / \mathrm{mol} ; \mathrm{GD}=83 \pm 5 \%)$. Entretanto, a presença de quitosana no tampão além causar uma drástica fluidização dos filmes de DPPG e de colesterol (redução do módulo de compressão, sobretudo dos filmes de DPPG), ela também faz com que este novo grau de fluidez dos filmes de DPPG e de colesterol não se altere frente a diferentes pHs. É como se agora as propriedades mecânicas dos filmes dependessem exclusivamente das propriedades mecânicas da quitosana adsorvida na interface. Outro detalhe relevante é que foi justamente na condição de menor $\mathrm{pH}$ de subfase $(\mathrm{pH}=3,5)$ que as quitosanas causaram as maiores perturbações do filme lipídico de DPPG(-). Elas aumentaram o espaço disponível por lipídio DPPG(-) e fluidizaram mais a monocamada em relação à monocamada controle (sem quitosana).63 Tais resultados enfatizam a relevância das interações eletrostáticas para a atividade das quitosanas: quanto menor o pH da solução, mais ácida ela é e, portanto, mais protonada e carregada positivamente a quitosana fica. Além disso, é preciso levar em conta que o pKa dos grupos fosfato das cabeças polares de DPPG(-) é cerca de $\mathrm{pKa}=4,0$. Ou seja, em soluções muito ácidas $(\mathrm{pH}<4,0)$, tais soluções de subfase protonariam também os grupos fosforil, tais que as cabeças polares perderiam a carga negativa. Tal diminuição de cargas negativas mitiga a repulsão eletrostática entre as cabeças na interface, justificando o comportamento de maior grau de compactação/rigidez da monocamada pura (DPPG) para baixos valores de pH $(3,5)$ em relação aos de alto $\mathrm{pH}(6,0)$.

Essas variações no grau do comportamento do filme lipídico são importantes porque podem afetar o mecanismo de interação das quitosanas com os fosfolipídeos. 57 Em um trabalho do nosso grupo de 2007, PAVINATTO et al. mostraram que quitosanas ( $M w \approx 110.000 \mathrm{~g} / \mathrm{mol} ; \mathrm{GD}=85 \%$; tampão TS em $\mathrm{pH}=3,0$ ) adsorvem imediatamente na 
interface líquido-ar contendo filmes lipídicos de DPPG(-) ou DPPC( \pm ) bem esparsos. ${ }^{57}$ Neste caso, a quitosana tem contato com as caudas lipídicas, podendo fazer interações hidrofóbicas. Entretanto, conforme se aumenta o grau de compactação dos lipídeos, as quitosanas são expelidas da interface líquido-ar, mas permanecem na camada logo abaixo desta interface interagindo somente com os grupos da cabeça polar (provavelmente com interações eletrostáticas, tipo íon-dipolo e/ou de hidrogênio). No caso de DPPG(-), o filme peormanece expandido até altos valores de pressão superficial devido à presença de quitosana, diferentemente de $\operatorname{DPPC}( \pm)$, que para valores acima de $42 \mathrm{mN} / \mathrm{m}$ a isoterma da interface é praticamente idêntica ao do DPPC puro. Neste mesmo trabalho, foi verificado que o potencial de membrana da monocamada DPPC( \pm ) é muito menos susceptível a alterações devido à presença quitosanas na subfase do que as monocamadas de DPPG(-). Vale ressaltar que a maior redução do potencial de membrana ocorreu para monocamadas esparsas de DPPG(-). ${ }^{57}$ Já em outro trabalho com DMPA no mesmo ano, nosso grupo investigou as interações entre filmes lipídicos de DMPA(-) com quitosanas (Mw $\approx 110.000 \mathrm{~g} / \mathrm{mol}$; GD 85\%; tampão TS em pH=3,0) usando Espectroscopia vibracional SFG e analisou a rugosidade dos filmes por Microscopia de Força Atômica (AFM). ${ }^{58}$ As quitosanas também alteraram as propriedades elásticas do filme de Langmuir de DMPA, reduzindo o módulo de compressão (tornando-a menos rígida) e expandindo o filme lipídico. Além disso, verificou-se por Espectroscopia SFG que as quitosanas aumentaram o ordenamento molecular das caudas hidrofóbicas dos DMPAs (medida verificada pela diminuição relativa de conformações gauche dos lipídeos na monocamada). Já por AFM, filmes LB de DMPA-quitosana demonstraram ser mais espessos e rugosos, também contendo agregados. 0 modelo de interação sugerido foi igual ao de DPPG(-), em que moléculas de quitosana permanecem como uma primeira camada interagindo somente com as cabeças polares dos fosfolipídios, causando uma redução na rigidez da monocamada ao passo que expande o filme na interface líquido-ar. Dois anos mais tarde, nosso grupo concluiu que quitosanas alteram de alguma forma a orientação molecular dos grupos fosfato das cabeças polares de DMPA (-) na interface e que esta interação é maior conforme se aumenta a compressão do filme. 62

Sabe-se também que a atividade antimicrobiana das quitosanas depende drasticamente do seu tamanho molecular. ${ }^{46,55,61,63}$ Em particular, PAVINATTO et al. propuseram uma classificação polimérica de tamanhos moleculares da seguinte forma: 
oligômeros de quitosana (OQ) como moléculas entre $1000 \mathrm{~g} / \mathrm{mol} \leq \mathrm{Mw} \leq 10.000 \mathrm{~g} / \mathrm{mol}$; polímeros de baixa massa molecular entre $10.000 \mathrm{~g} / \mathrm{mol} \leq \mathrm{Mw} \leq 250.000 \mathrm{~g} / \mathrm{mol}$; e polímeros de alta massa molecular como Mw > 250.000 g/mol. ${ }^{61}$ Em 2011, KRAJEWSKA et al. compararam o grau de perturbação que 3 quitosanas de tamanhos diferentes $\left(\mathrm{Mw}_{(1)}=360 \pm 1 \mathrm{kDa}\right.$ com GD=81 $\pm 2 \% ; \mathrm{Mw}_{(2)}=1202 \pm 2 \mathrm{kDa}$ com GD=83 $\pm 5 \%$; e $\mathrm{Mw}_{(3)}=2506 \pm 14 \mathrm{kDa}$ com $\mathrm{GD}=77 \pm 2 \%$; em tampão acetato $\mathrm{pH}=3,5$ ) em filmes de Langmuir de DPPG(-), DPPC( \pm ) e colesterol. 63 Eles verificaram que quanto menor o tamanho molecular da quitosana, maior era sua interação com tais modelos de membrana. Em 2013, nosso grupo confirmou essa tendência. ${ }^{61}$ PAVINATTO et al. 2013 verificaram que quitosanas (em subfase de tampão TS de pH 3,0) com menores massas moleculares $\left(\mathrm{Mw}_{(\mathrm{L})}=113.000 \mathrm{~g} / \mathrm{mol} ; \mathrm{GD}=94 \%\right)$ perturbam de fato mais filmes de Langmuir aniônicos (DMPA) do que de alta massa molecular $\left(\mathrm{Mw}_{(\mathrm{H})}=213.000 \mathrm{~g} / \mathrm{mol}\right.$; GD=94\%). ${ }^{61}$ Além disso, eles também verificaram que se reduzíssemos muito o tamanho das quitosanas, usando seus monômeros livres $\left(\mathrm{Mw}_{(\mathrm{NAG})}=221,21 \mathrm{~g} / \mathrm{mol}\right.$ e $\operatorname{Mw}_{(\text {GlicN })}=164,16 \mathrm{~g} / \mathrm{mol} ;$ SIGMA-Aldrich ${ }^{\circledR}$ ), a interação deles com os modelos de membrana de DMPA também diminuía. Logo, quitosanas classificadas como oligômeros de quitosana e de baixa massa molecular deveriam ter as melhores capacidades de perturbação de membranas. ${ }^{61}$

Nota-se, portanto, que em se tratando de interações entre as quitosanas e os modelos de membrana (i.e., interações biomoleculares tipo polissacarídeo-lipídeo), sabe-se mais a respeito dos efeitos macroscópicos causados pela quitosana nas monocamadas lipídicas (medidas comparativas de parâmetros termodinâmicos entre filmes lipídicos na presença e na ausência de quitosanas na subfase) do que quais grupos químicos que estão atuando de fato ou sendo afetados durante a interação. Há pouquíssimos trabalhos que realmente abordam o ponto de vista molecular dessas interações usando esses modelos. Além disso, são poucos os trabalhos envolvendo oligômeros de quitosana $(1.000 \mathrm{~g} / \mathrm{mol} \leq \mathrm{Mw} \leq 10.000 \mathrm{~g} / \mathrm{mol})$, sobretudo em estudos nos quais a subfase tem $\mathrm{pH}$ próximo do $\mathrm{pH}$ neutro. Vale ressaltar que praticamente todos os artigos na área clamam pela importância de se obter tais informações em nível molecular. ${ }^{46,53-55}$ Isso se deve ao fato de que a comunidade científica de fato acredita que tais informações sejam fundamentais para o desenvolvimento racional de novos 
compostos antimicrobianos que atacam seletivamente às membranas de microrganismos, e não às membranas de células humanas. 


\section{OBJETIVO}

Nós aqui investigaremos as interações moleculares de polieletrólitos catiônicos antimicrobianos em modelos planares de membrana (Filmes de Langmuir). ${ }^{68}$ Para isso, usaremos a Espectroscopia SFG em Filmes de Langmuir de diferentes composições lipídicas. ${ }^{68-74}$ Um desses filmes, com fosfolipídeos de cabeça polar aniônica, DPPG (1,2dipalmitoil-sn-glicero-3-fosfo-(1'-rac-glicerol)), modelará as biomembranas bacterianas. O outro Filme de Langmuir, com fosfolipídeos de cabeça polar zwitteriônica, DPPC (1,2dipalmitoil-sn-glicero-3-fosfocolina), simulará a membrana plasmática de células de humanos. Por fim, compararemos esses sistemas quando sob a ação de dois polieletrólitos antimicrobianos: os oligômeros de quitosana $(\mathrm{OQ}$, polieletrólito catiônico biocompatível com células humanas, (FIGURA 07.b) e o poli(hidrocloreto de alilamina) (PAH, polieletrólito catiônico tóxico às células humanas (TABELA 02.a). ${ }^{29}$ Duas metodologias de interação serão utilizadas: uma que mede o grau de afinidade pela membrana (processo quase estático ao montar a monocamada lipídica com o composto antimicrobiano já solubilizado na subfase da cuba de Langmuir) e a outra, que mede o grau de penetração do antimicrobiano na membrana (processo dinâmico de injeção do antimicrobiano na subfase após a monocamada lipídica já ter sido formada a uma certa pressão superficial). Ao unirmos tanto as informações macroscópicas (termodinâmica da membrana), quanto microscópicas (espectros SFG) desses sistemas, teremos um conjunto de dados que propiciará um entendimento mais detalhado do que acontece do ponto de vista molecular - nesses modelos de membrana. Baseando-se em tais informações, podemos sugerir mecanismos de interação molecular entre os polieletrólitos antimicrobianos e os Filmes de Langmuir. 


\section{SEÇÃO TEÓRICA}

\subsection{FUNDAMENTOS DA ESTRUTURA CELULAR}

\subsubsection{Células}

Todas as coisas vivas são feitas de células. ${ }^{1}$ Logo, células podem ser definidas como as unidades básicas da vida. Uma das maneiras mais tradicionais e simples de serem classificadas é dividindo-as em dois grupos principais: em Células Eucarióticas (como as células de animais, vegetais, fungos, etc) e em Células Procarióticas (bactérias, algas cianofíceas e micoplasmas) (FIGURAS 07-08).1,67 Células procarióticas são muito diferentes das células eucarióticas por não apresentarem compartimentos especializados dentro delas (TABELA 03). Por exemplo, em células bacterianas, todos os processos metabólicos acontecem em um único espaço: não há um núcleo ou outras estruturas membranosas em seu interior dividindo o espaço intracelular. Já em células eucarióticas, invaginações e evaginações das membranas plasmáticas criam novos compartimentos e dividem espaços na célula. Cada compartimento intracelular tem sua função, seu conjunto de atividades metabólicas. Portanto, a célula eucariótica é mais organizada, podendo efetuar funções mais complexas sem afetar negativamente o seu metabolismo. Por exemplo, embora todas as diferentes células de um humano tenham o mesmo DNA, o que explica essa enorme diversidade de tipos celulares e funções é justamente a capacidade organizar a atividade metabólica desses compartimentos.

FIGURA 07 - CÉLULAS PROCARIÓTICAS E EUCARIÓTICAS. (a) Célula Procariótica e suas estruturas. (b) Célula Eucariótica e suas principais organelas.
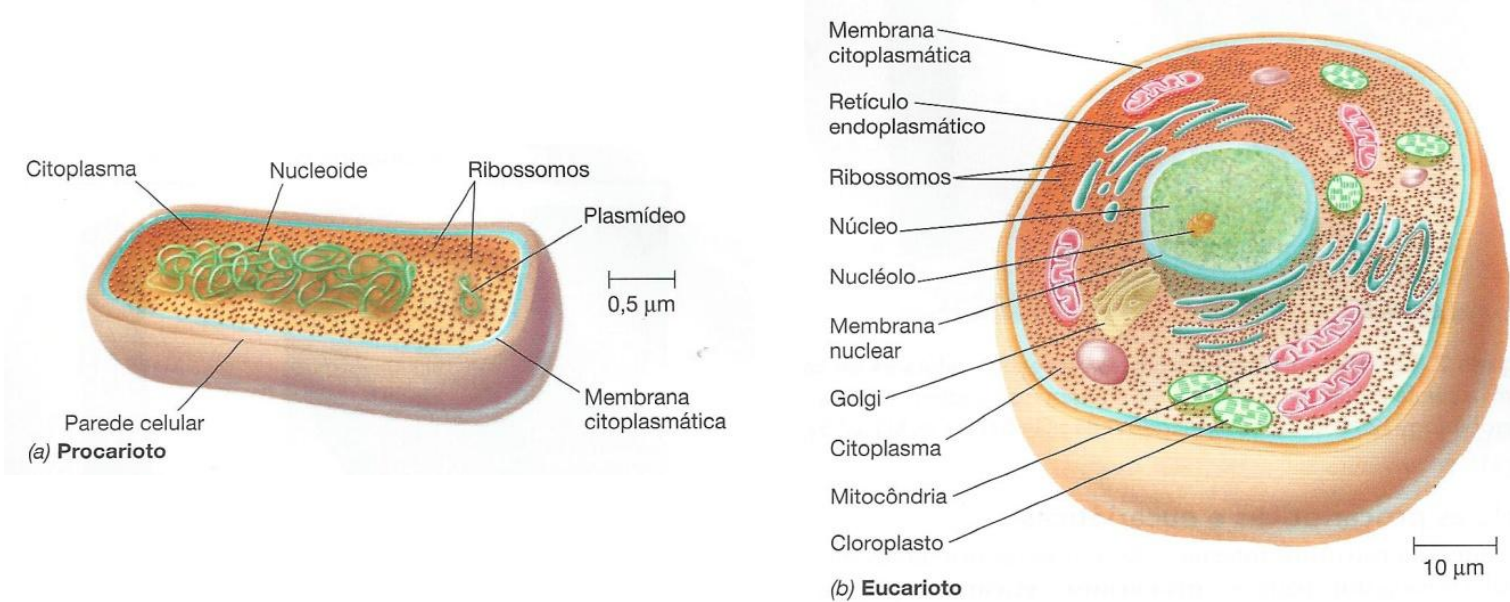

Fonte: MADIGAN et al $^{67}$. 
FIGURA 08 - MICROGRAFIAS DE CÉLULAS PROCARIÓTICAS E EUCARIÓTICAS. (a), (b) Células Procarióticas. (c) Célula Eucariótica. Note que somente em eucariotos há membranas separando ambientes

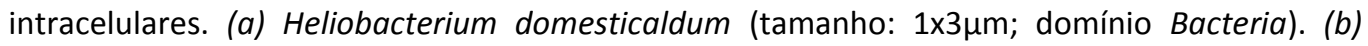

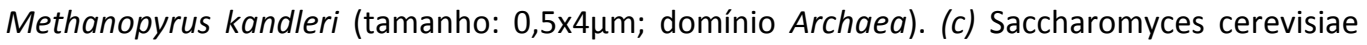
(tamanho: $8 \mu \mathrm{m}$ de diâmetro; domínio Eukarya).

\section{Procariotos}

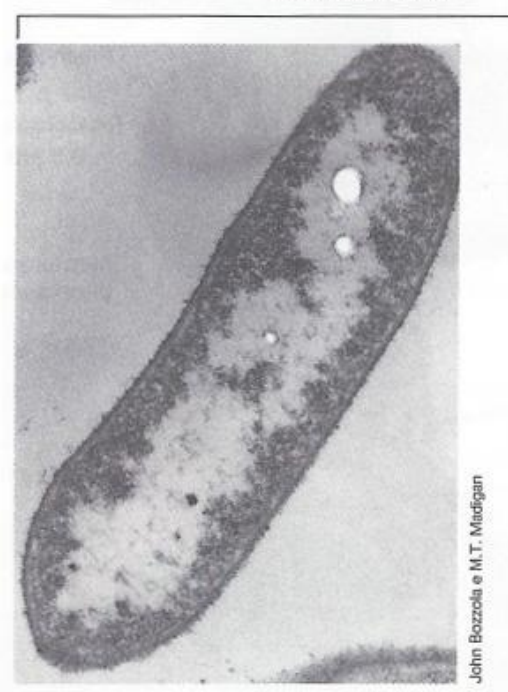

(a) Bacteria (b) Archaea

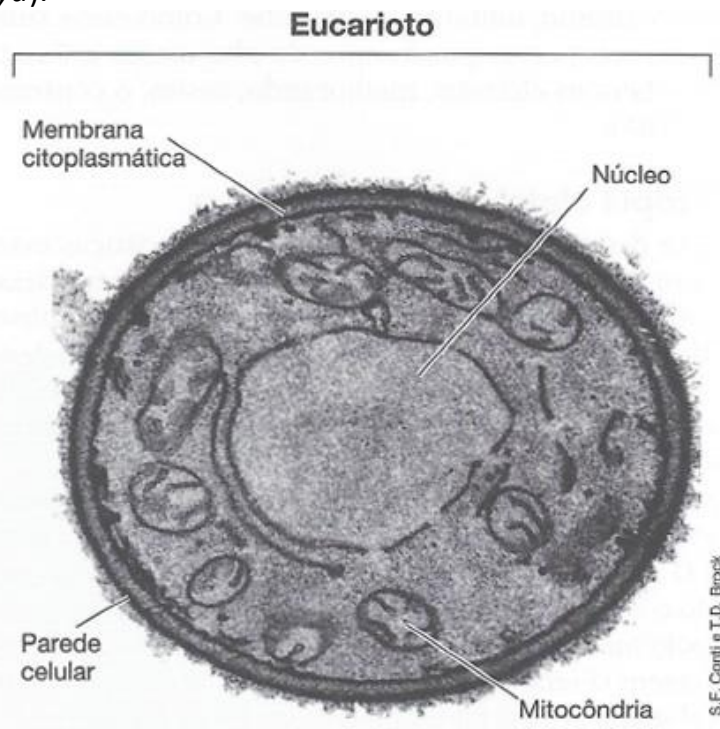

(c) Eukarya

Fonte: MADIGAN et al ${ }^{67}$

TABELA 03 - DIFERENÇAS INTRACELULARES ENTRE EUCARIOTOS E PROCARIOTOS.

\begin{tabular}{|c|c|c|}
\hline $\begin{array}{c}\text { Estruturas Membranosas Intracelulares: } \\
\text { Núcleo, Retículo Endoplasmático Liso, Retículo } \\
\text { Endoplasmático Rugoso, Complexo de Golgi, etc. }\end{array}$ & $\begin{array}{c}\text { CÉLUS } \\
\text { PROCARIÓTICAS } \\
\text { (ex.: bactérias) }\end{array}$ & $\begin{array}{c}\text { CÉLULAS } \\
\text { EUCARIÓTICAS } \\
\text { (ex.: células de humanos) }\end{array}$ \\
\hline Mitocôndria & Não & Sim \\
\hline $\begin{array}{c}\text { Organelas responsáveis por fotossíntese: } \\
\text { Plastídeos Intracelulares }\end{array}$ & Não & Sim \\
\hline Organização do Material Genético & Disperso no Citoplasma & Empacotado no Núcleo \\
\hline Material Genético & DNAs circulares & $\begin{array}{c}\text { Cromatina } \\
\text { (DNAs lineares + Histonas) }\end{array}$ \\
\hline Genes & Contíguos & Não contíguos \\
(Éxons e Íntrons)
\end{tabular}

Fonte: Adaptada de ALBERTS ${ }^{1}$ 


\subsubsection{Membranas Biológicas}

Além das membranas biológicas permitirem a organização celular em eucariotos por meio da compartimentalização, elas são estruturas fundamentais para a existência de vida. Por exemplo, em organismos unicelulares, os $\approx 5 \mathrm{~nm}$ de espessura das membranas separam a região que tem vida da que não tem.1,67 São as membranas que respondem a estímulos externos, transmitindo informações entre os meios intracelular (vida) e extracelular (ambiente ou outro organismo). ${ }^{1,67}$ Elas controlam o fluxo de substâncias que entram e saem do microrganismo, atuam como uma barreira físicoquímica de proteção, se aderem a superfícies, carregam substâncias hidrofóbicas e anfifílicas importantes do metabolismo celular que catalisam reações químicas, são flexíveis o bastante para englobar outras células, propagam sinais elétricos, etc. Sua estrutura é semelhante a um mosaico fluido, em que as moléculas que a constituem tem liberdade para se movimentar na membrana (FIGURA 09).

FIGURA 09 - MEMBRANA COMO UM MOSAICO FLUIDO. Fosfolipídeos e proteínas tem liberdade para transladar na bicamada lipídica.

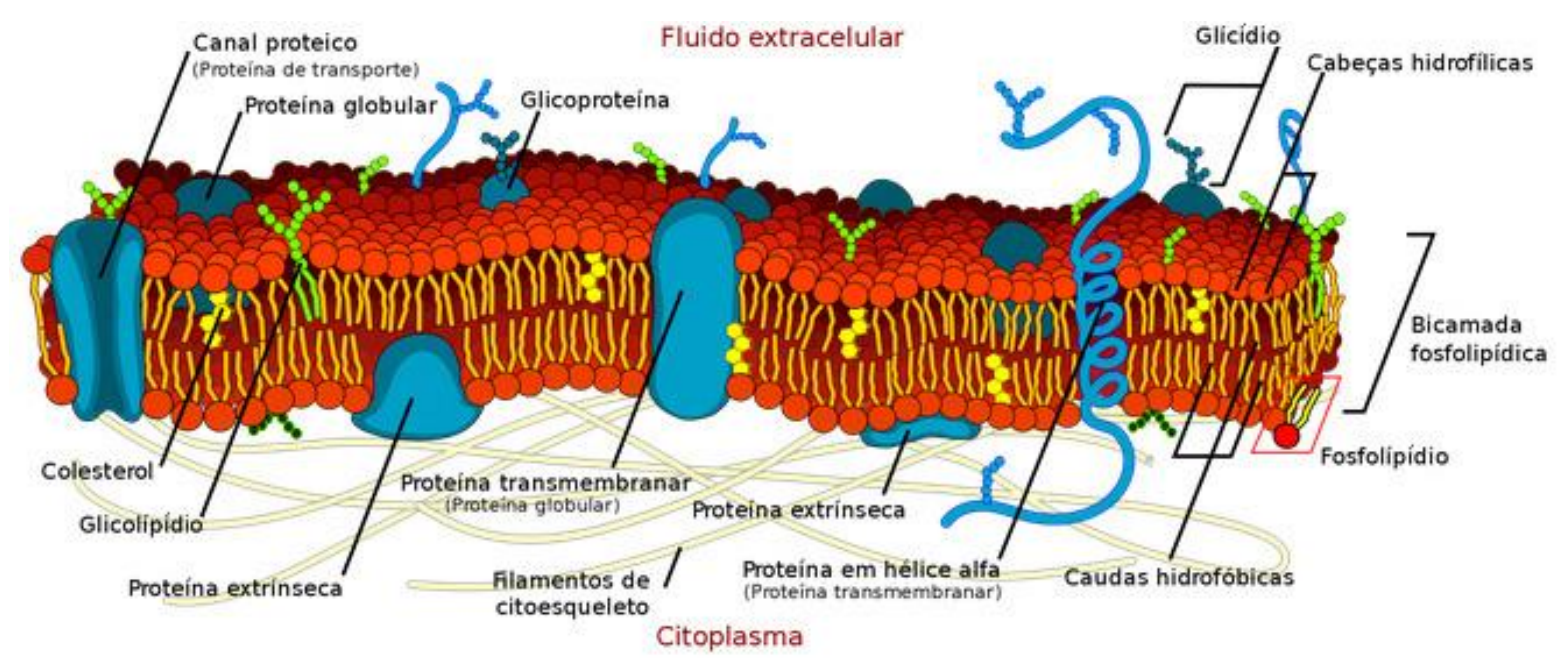

Fonte: WIKIPEDIA. ${ }^{75}$ 


\subsubsection{A Estrutura Molecular das Membranas}

A principal classe de moléculas que constitui as Membranas Celulares são os Lipídeos (FIGURA 09). ${ }^{76} \mathrm{~A}$ família de compostos lipídicos é muito vasta (Fosfolipídeos, Glicerídeos, Cerídeos, Carotenóides, Esteróides, etc). ${ }^{76}$ A propriedade comum deles é que são biomoléculas anfifílicas: tem uma cabeça polar (hidrofílica), que fica exposta para o meio aquoso, e uma cauda apolar (hidrofóbica), que fica escondida do meio aquoso. Embora as membranas dos compartimentos celulares difiram em composição umas das outras, a estrutura básica é a mesma, inclusive entre células procarióticas e eucarióticas. Membranas Celulares (MCs) em geral são compostas por uma bicamada lipídica que tem proteínas embebidas nelas e são suportadas por fibras do citoesqueleto intracelular (FIGURA 09).1,67 Citoesqueleto são redes de fibras que servem de trilhos para transporte de substâncias e também dá a sustentação para morfologia da célula. ${ }^{1}$. Conforme o citoesqueleto se modifica, o formato da célula também. Logo, a bicamada lipídica é muito flexível e dinâmica para acompanhar o citoesqueleto. Além disso, os folhetos lipídicos que constituem a bicamada são assimétricos. Ou seja, a composição química da monocamada superior é necessariamente diferente da inferior. Inclusive, um lipídeo de uma monocamada pode passar a povoar o outro folheto lipídico (processo chamado de flip-flop, que geralmente é mediado por proteínas na membrana). ${ }^{1}$ Então, a membrana pode ser considerada um fluido viscoso de composição controlada, de modo que todas as moléculas da membrana (lipídeos e proteínas) tem liberdade de se locomover nela. ${ }^{1,67,76}$

\subsubsection{Biomembranas Bacterianas}

Diferentes espécies de procariotos podem diferir no tipo de biomembrana que as enclausuram. Algumas são envoltas somente por uma Membrana Plasmática (MP), que é a típica bicamada lipídica embebida por proteínas (exemplo: Micoplasmas e outros protoplastos). ${ }^{67}$ Porém, outros procariotos podem também ter um revestimento extra, chamado Parede Celular (PC), de espessura típica entre $3 \mathrm{~nm}$ a $25 \mathrm{~nm} .{ }^{66-67}$ As paredes celulares bacterianas são tão importantes para o ramo da microbiologia que o principal método de classificação bacteriana é baseado nelas. ${ }^{67}$ Ao usar a técnica de Coloração de Gram para corar bactérias em microscópio, é possível discernir bactérias que tem 
paredes celulares com pouca Mureína (Peptidoglicano) das que tem muito. Os peptideoglicanos são constituídos de polissacarídeos (unidades consecutivas de $\mathrm{N}$ acetilglicosamina, NAG, e de ácido N-acetilmurâmico, NAM) entrecruzados por ligações interpeptídeos (FIGURA 10.a-b). Na técnica de coloração Gram (FIGURA 10.c-d), quando corante Violeta de Metila (VMCl, FIGURA 10.e) é adicionado ao meio aquoso, ele se dissocia $\left(\mathrm{VM}^{+}\right.$e $\left.\mathrm{Cl}^{-}\right)$, podendo interagir com as cargas negativas da parede celular. $\mathrm{A}$ adição de iodo forma complexos com corante, retendo-o na parede mesmo após o tratamento de etanol/acetona (enxágue para descoloração). Logo, as bactérias que ficam com coloração violeta após este enxágue são chamadas de Bactérias Gram-Positivas (Gram+). ${ }^{76-77}$ Já as bactérias que não conseguem reter esse corante são denominadas Gram-Negativas (Gram-). ${ }^{76-77}$

FIGURA 10 - O MÉTODO DE COLORAÇÃO GRAM. (a) e (b) Estrutura química e morfologia esquemática da mureína respectivamente. (c) Etapas da técnica de coloração de Gram. (d) Micrografia evidenciando uma cultura de bactérias gram-positivas (em violeta, Staphylococcus aureus) e gram-negativas (em rosa, Escherichia coli). (e) Estrutura química do corante Violeta de Metila.

(a)

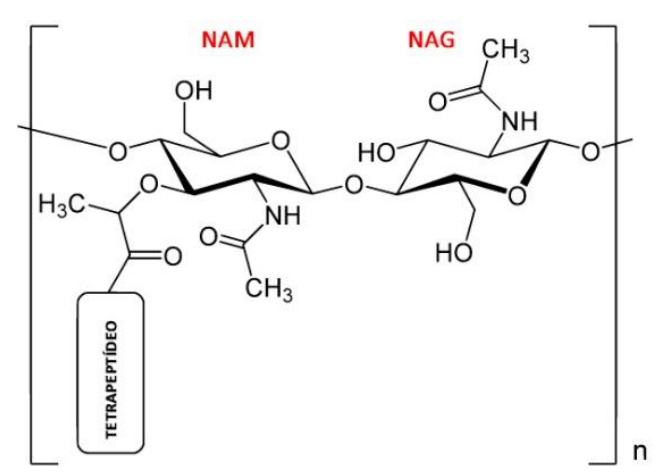

(c)

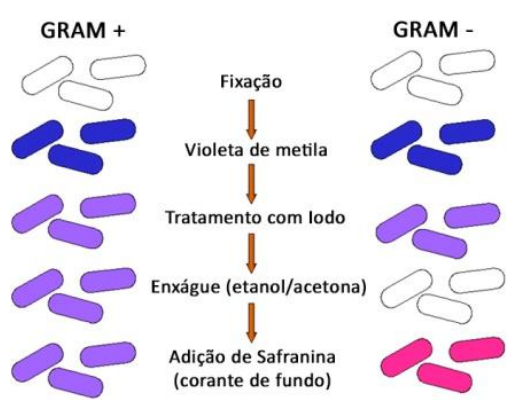

(b)

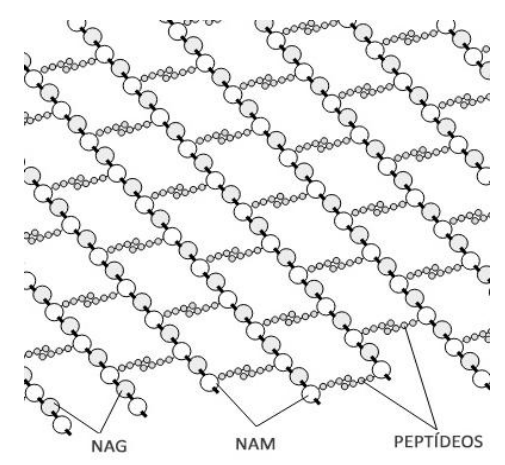

(e)

(d)

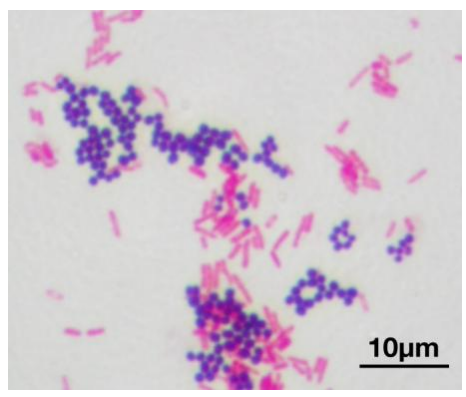

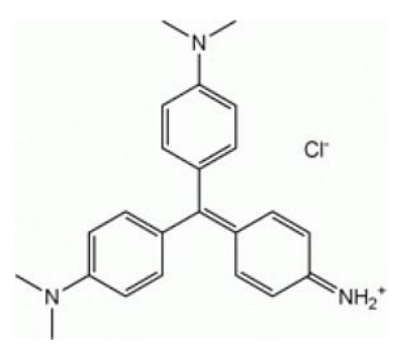

Fontes: $(a, b, d, e)$ Adaptadas de WIKIPEDIA. ${ }^{77-78,80}$ (c) Adaptada de LOYOLA... ${ }^{79}$ 
FIGURA 11 - CLASSIFICAÇÃO CLÁSSICA DE BACTÉRIAS. (a) Ilustrações das paredes celulares de bactérias Grampositivas e (b) Gram-negativas. (c, d) Micrografias* eletrônicas de transmissão da parede celular de bactéria Gram-positiva (Arthrobacter crystallopoietes, largura célula na imagem $\approx 1,5 \mu m$ ) e de Gram-negativa (Leucothrix mucor, largura da célula na imagem $\approx 2,5 \mu \mathrm{m}$ ) respectivamente. *São iguais as de MADIGAN et al ${ }^{67}$.

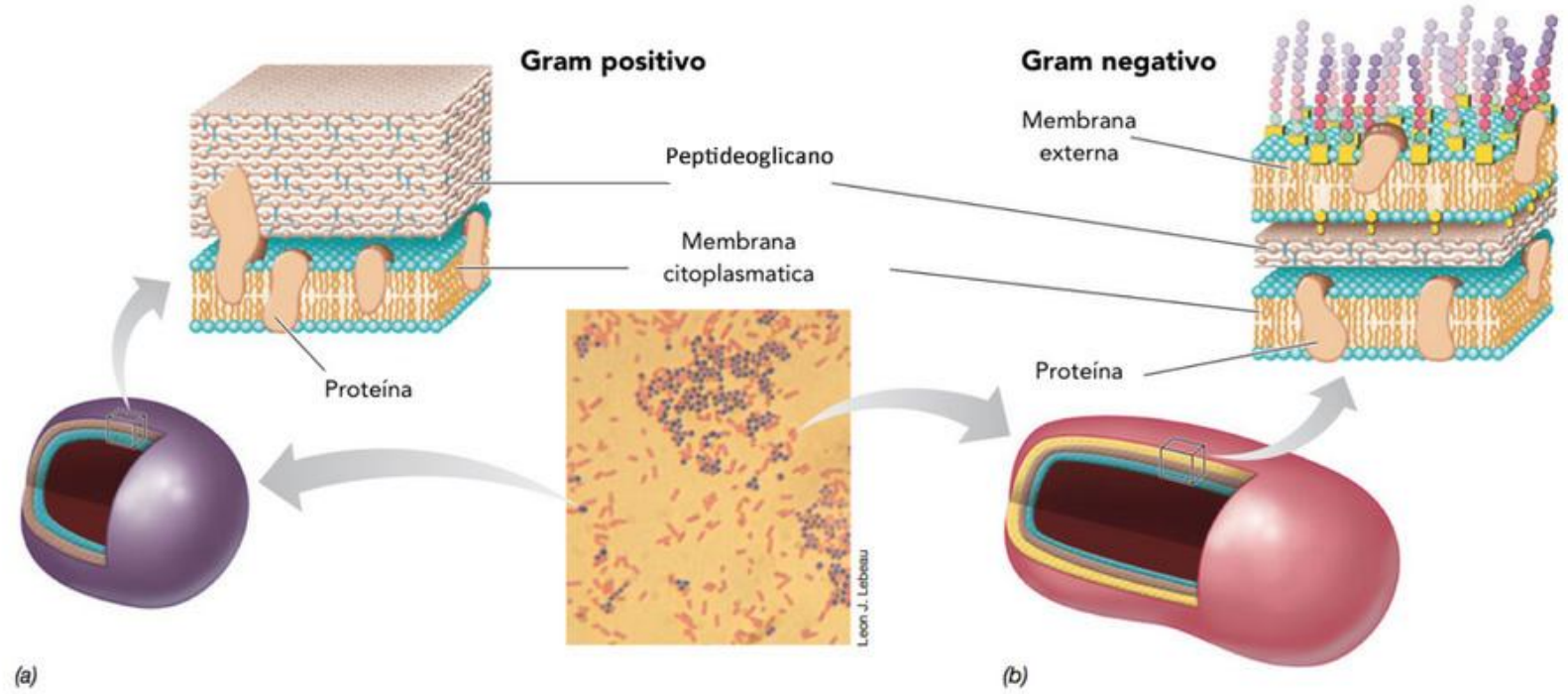

(a)

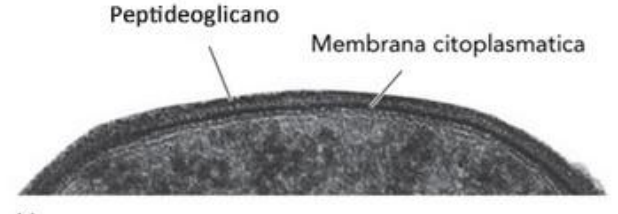

(c) (b)

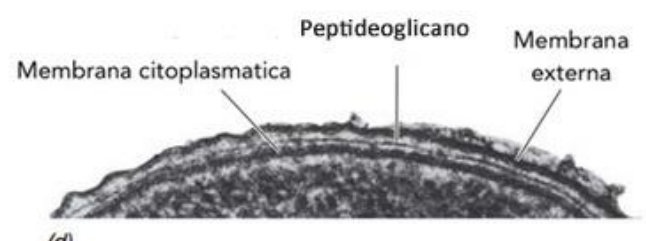

Fonte: CENTRO... ${ }^{81}$.

\subsubsection{Biomembranas de Bactérias Gram+}

Como dito anteriormente, bactérias que tem paredes celulares ricas em peptideoglicano (mureína) permanecem coradas pelo Método de coloração de Gram e, por esta razão, são denominadas Bactérias Gram-Positivas. ${ }^{67}$ Nestas, cerca de $90 \%$ de toda a parede celular é constituída de peptideoglicano, ${ }^{67}$ o que confere rigidez à bactéria. Entretanto, como a FIGURA 11 ilustra bem, há mais diferenças entre as biomembranas de bactérias Gram-positivas e Gram-negativas do que simplesmente a quantidade de mureína. Por exemplo, somente em bactérias Gram-positivas há moléculas de ácido teicóico ligadas covalentemente a resíduos de NAM (ácido N-acetilmurâmico) da parede celular. Ácidos Teicóicos são polieletrólitos aniônicos cujas unidades repetitivas de glicerol-fosfato ou ribitol-fosfato são conectados pelos ésteres fosfato. As unidades dos polialcoóis glicerol e ribitol tem grupos hidroxilas (3 e 5 respectivamente) que podem 
ser substituídas por outros açúcares ou D-Alanina (aminoácido) (FIGURA 12.a). Por carregarem vários grupos fosfato ao longo da cadeia, os ácidos teicóicos são parcialmente responsáveis pela carga negativa da superfície de bactérias Grampositivas. Além disso, eles atuam na complexação de cátions divalentes ( $\mathrm{Ca}^{2+}$ e $\left.\mathrm{Mg}^{2+}\right)$ para o transporte destes para o interior da célula. Ácidos lipoteicóicos são ácidos teicóicos ligados covalentemente a lipídeos da membrana plasmática (FIGURA 12.b).

FIGURA 12 - BIOMEMBRANA DE BACTÉRIA GRAM-POSITIVA. (a) Estrutura química de uma unidade de ácido teicóico tipo ribitol encontrado em Bacilus subtilis. Cores verde, vermelho e azul representam grupos de monossacarídeo, aminoácido e grupo fosfato respectivamente. (b) as principais estruturas da parede de gram-positivas. Note que os ácidos lipoteicóicos atravessam toda a parede e se ancoram na membrana citoplasmática.

(a)

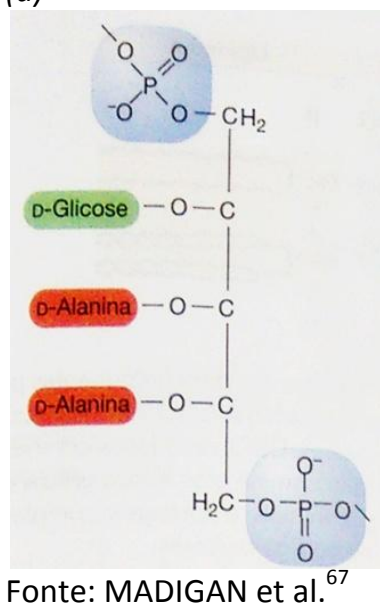

(b)

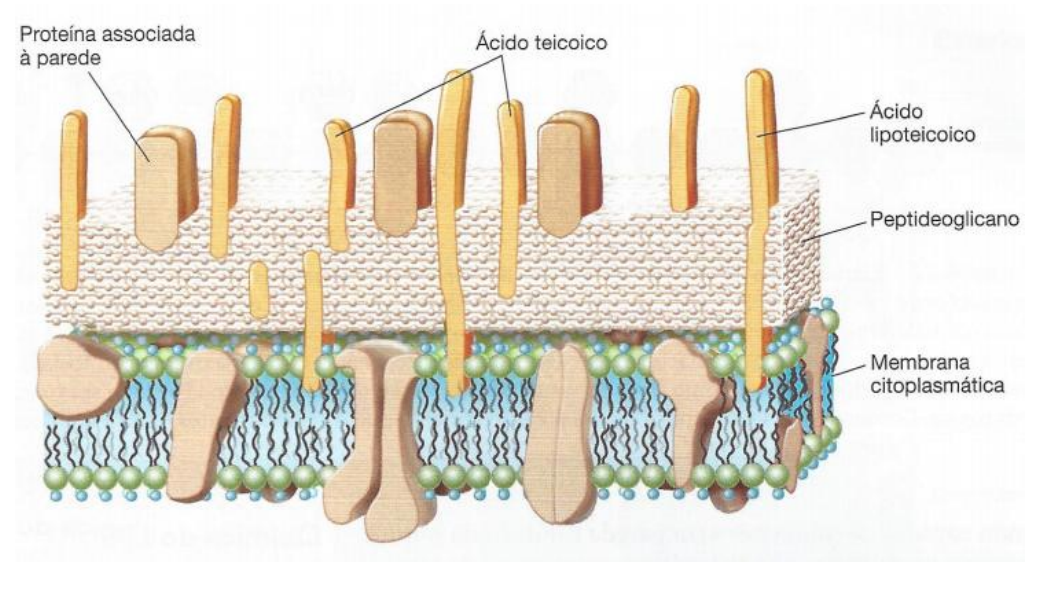

\subsubsection{Biomembranas de Bactérias Gram-}

As bactérias Gram-negativas tem parede celular bem mais complexa. Em contraste com as biomembranas de bactérias Gram-positivas, cerca de somente $10 \%$ da parede celular das bactérias Gram-negativas são constituídas de peptideoglicano. ${ }^{67}$ Ademais, as bactérias Gram-negativas tem uma segunda bicamada lipídica externa (FIGURA 13.a). Em tal membrana externa, além de ter alguns fosfolipídeos e proteínas convencionais, há também biomoléculas chamadas de Lipopolissacarídeos (LPS), que são os constituintes predominantes do folheto externo desta bicamada.67,82-84 Já o 
folheto interno dessa bicamada externa se assemelha mais em composição à membrana (cito)plasmática bacteriana, com exceção de que há complexos lipoproteicos que agem como âncoras conectando-se ao peptideoglicano. Além disso, graças a outros complexos proteicos denominados de Porinas, há um trânsito de moléculas pequenas hidrofílicas (de massa molar menor que $\approx 600 \mathrm{~g} / \mathrm{mol}$ ) entre o ambiente extracelular e o Periplasma (FIGURAS 13.a-b).67,82-84. Dependendo da Porina, ela pode transportar uma classe de moléculas em específico ou não. 0 espaço periplasmático (cerca de $15 \mathrm{~nm}$ de espessura entre as duas bicamadas lipídicas) é um ambiente aquoso com viscosidade semelhante a um gel, devido à alta concentração de proteínas das mais diversas funções (degradação e transporte de substâncias, quimiorreceptores, etc).

Os LPS são moléculas lipídicas ligadas covalentemente a polissacarídeos (FIGURA 13.c). ${ }^{84}$ A parte lipídica é chamada de Lipídeo A, que pode ser tóxica aos animais. Logo, a membrana externa de bactérias Gram-negativas eventualmente pode ser tóxica para os seres humanos. Inclusive, alguns sintomas intestinais de patógenos como Salmonella, Shigella e Escherichia coli são devidos a essa membrana externa. 0 Lipídeo A não é um lipídeo convencional derivado de glicerol, posto que as caudas de ácidos graxos estão ligadas aos grupos amina de um dissacarídeo de glicosamina-fosfato (GlicN-PO${ }_{4}^{-}$). Já a parte polissacarídica pode ser dividida em duas partes: o polissacarídeo interno (cerne) e o polissacarídeo externo (O-específico) (FIGURA 13.c) ${ }^{67,84}$. 0 polissacarídeo cerne é constituído de cetodesoxioctonato (CDO), heptoses (açúcares de 7 carbonos), glicose, galactose (açúcares de 6 carbonos) e de N-acetilglicosamina (NAG). Já o Polissacarídeo O-específico, também conhecido como Antígeno 0, varia muito de espécie para espécie, mas geralmente é constituído de galactose, glicose, ramnose, manose e alguns dideoxiaçúcares menos usuais como abequose e colitose (TABELA 04). Tais açúcares formam sequências de quatro a cinco monossacarídeos ramificados que se repetem ao longo deste polissacarídeo externo (FIGURA 13.c). 
FIGURA 13 - BIOMEMBRANA DE BACTÉRIA GRAM-NEGATIVA. (a) uma biomembrana típica (Parede Celular e Membrana Plasmática) de bactérias Gram-negativas. Note que o folheto lipídico externo da membrana externa é densamente povoado por Lipopolissacarídeos (LPS). Note também que o peptideoglicano separa dois ambientes periplasmáticos. (b) Visão superior de uma estrutura cristalográfica da Porina (complexo de 3 proteínas em formato de barril, cujos átomos de carbono estão representados em verde, branco e amarelo; em vermelho, átomos de oxigênio e, em azul, átomos de nitrogênio). Tais complexos proteicos tem 4 poros ( 1 em cada barril- $\beta$ proteico e 1 na intersecção dos 3 barris, os poros tem $\approx 1 \mathrm{~nm}$ de diâmetro). (c) ilustrações simplificadas de um Lipopolissacarídeo (LPS) e suas principais partes: o Lipídeo A, o Polissacarídeo Cerne e o Polissacarídeo O-específico. Abreviações dos açúcares: GlcN, Glicosamina; P, grupo fosfato; CDO, cetodesoxioctonato; Hep, heptoses; Gli, glicose; Gal, galactose; Nac-Gli, N-acetilglicosamina. Note que há vários grupos fosfatos conferindo carga negativa ao LPS.

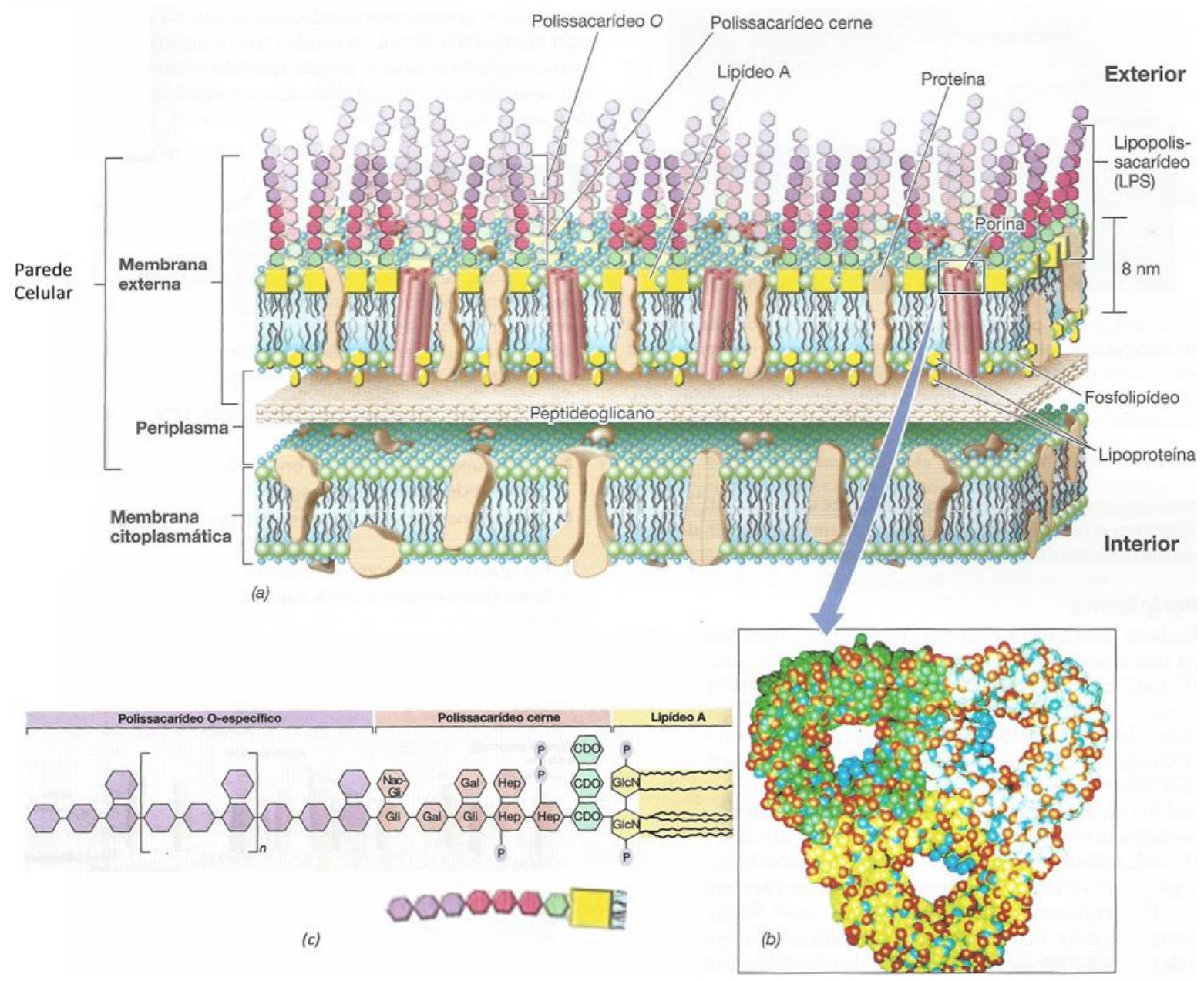

Fonte: Adaptada de MADIGAN et al. ${ }^{67}$ 
TABELA 04 - ESTRUTURAS QUÍMICAS DE ALGUNS MONOSSACARÍDEOS ENCONTRADOS NOS LPS.

\begin{tabular}{|l|l|l|}
\hline CDO & \multicolumn{2}{|c|}{ Hexoses convencionais } \\
\hline (a) Ácido de 2-ceto-3-deoxiaçúcar & (b) Glicose & (c) Galactose \\
\hline (d) Ramnose $_{\text {Dideoxiaçúcar usual }}$ & (e) Abequose \\
\hline Fonte: $\mathrm{SIGMA...85-88,90}$; ENZYME... & ${ }^{89}$
\end{tabular}

\subsubsection{Composição Lipídica das Membranas Celulares}

Bactérias (procariotos) e células humanas (eucariotos) variam drasticamente na composição de suas bicamadas lipídicas e, portanto, é esperado que compostos antimicrobianos que interagem com membranas tenham diferentes afinidades com as diferentes células. Por exemplo, o folheto externo das bicamadas lipídicas de células humanas é constituído majoritariamente por lipídeos zwiterônicos (que tem cabeças polares neutras, com ambas as cargas opostas, positiva e negativa, que serão abreviados aqui com seguinte símbolo “‡”). Nas células humanas, essa monocamada externa é principalmente constituída pelas cabeças polares tipo fosfatidil-colina (PC, \pm ) e outros lipídeos tipo esfingomielinas (SMs, \pm )(FIGURA 14).82-83 Já o folheto interno de células humanas, além de também ser constituído por fosfolipídeos zwiteriônicos tipo fosfatidiletanolamina (PE, \pm ), ele é também composto por lipídeos com cabeças polares carregadas negativamente (abreviados com o símbolo “-"). ${ }^{82-83}$. As caudas hidrofóbicas de tais fosfolipídeos geralmente são derivadas de ácidos graxos de 16 carbonos saturados (nomenclatura: palmitoil; derivado de palmitatos) ou com uma insaturação (nomenclatura: oleil; derivado de oleatos). Por outro lado, as biomembranas bacterianas tem um caráter claramente aniônico. Tal caráter se deve à presença de vários grupos fosfato nas paredes celulares de bactérias Gram-positivas (exemplo: nos ácidos teicóicos) e de Gram-negativas (exemplo: nos lipopolissacarídeos, LPS), além de suas 
membranas plasmáticas serem constituídas por uma fração mais significativa de fosfolipídeos aniônicos, comparado às células eucarióticas humanas (TABELA 05).

FIGURA 14 - ESTRUTURAS QUÍMICAS DE ALGUNS LIPÍDEOS IMPORTANTES.

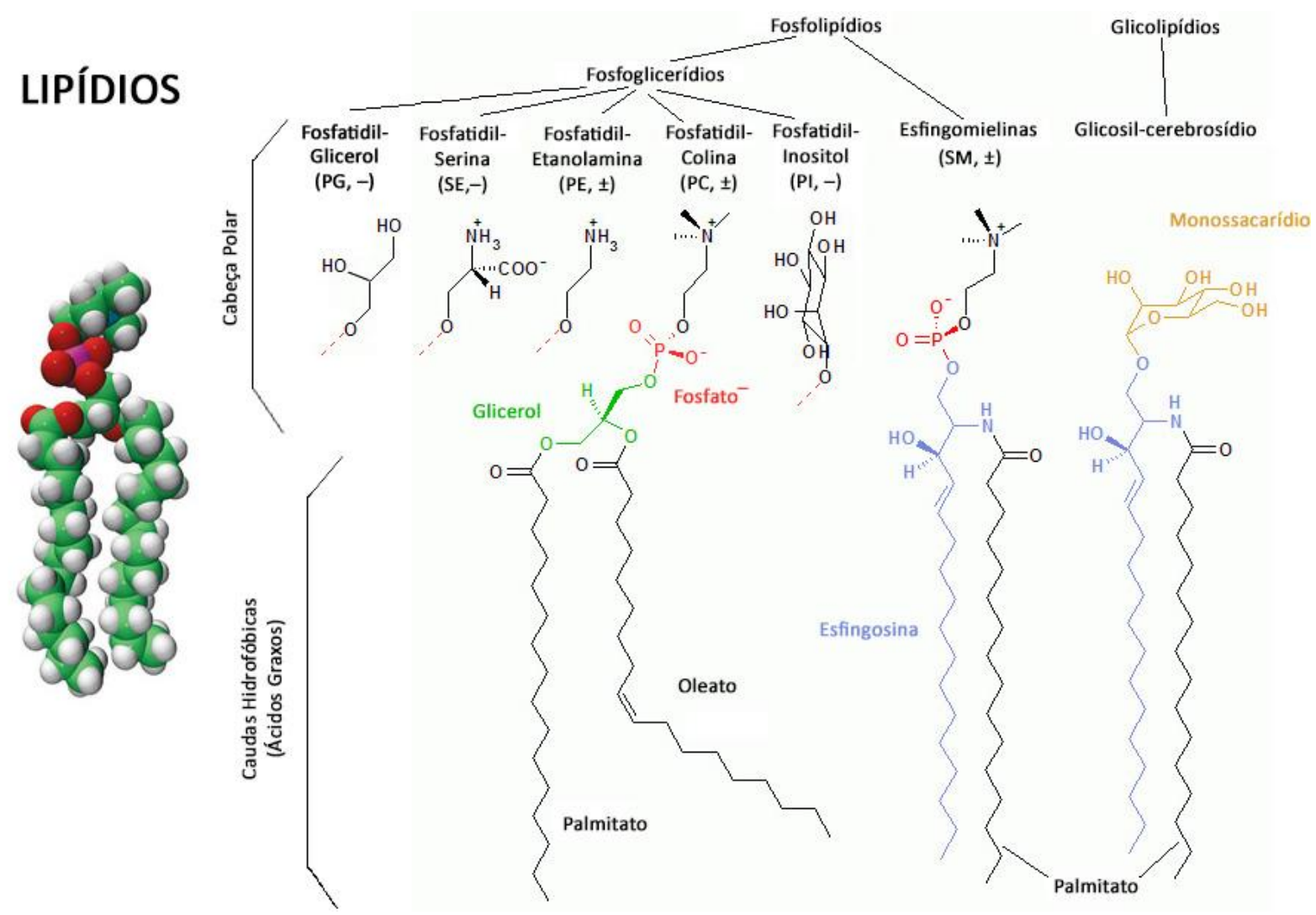

Lipídeo A

Lipopolissacarídio (LPS)
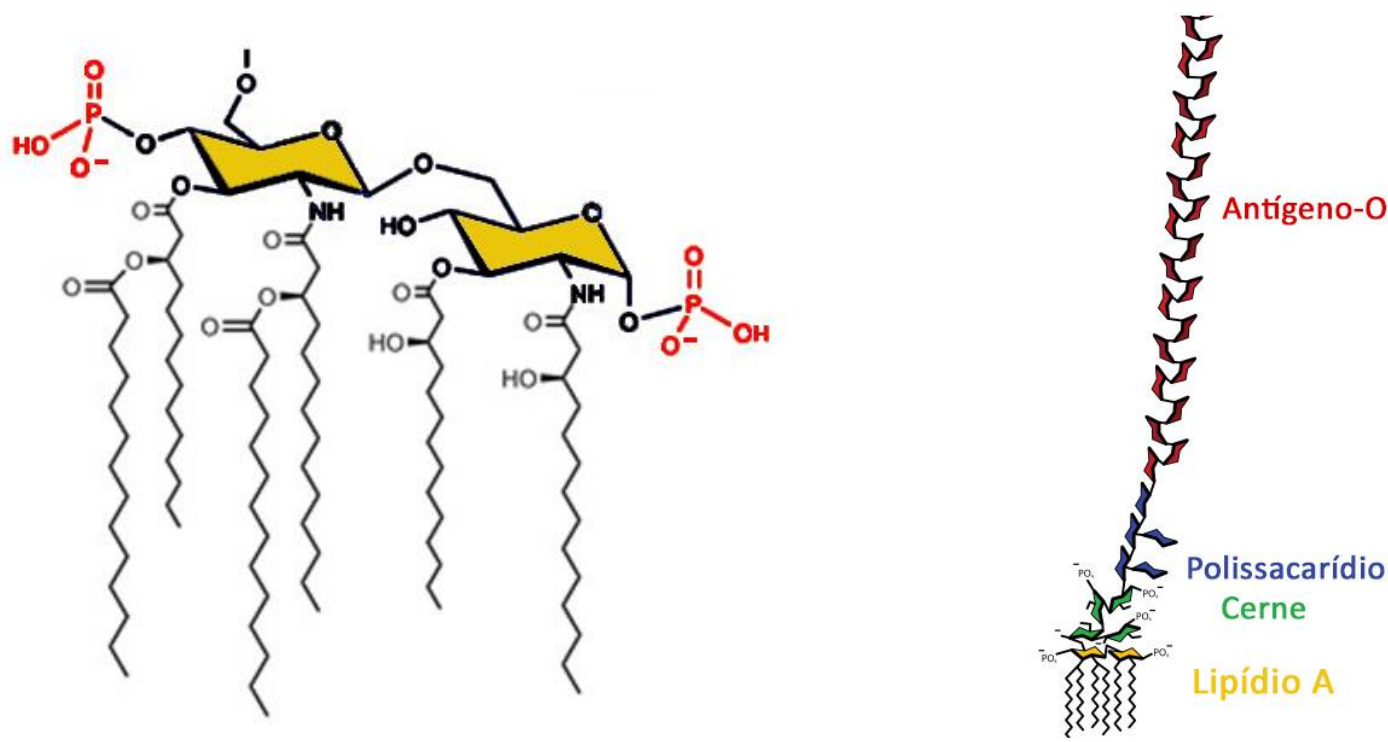

Fonte: Adaptada de WIKIPEDIA, ${ }^{76,84,91}$; AVANTI... ${ }^{92-93}$ 
TABELA 05 - FOSFOLIPÍDEOS MAJORITÁRIOS NAS MEMBRANAS CELULARES. (a) Fosfolipídeos de células de mamíferos (eucarióticas). Note que listamos a composição lipídica tanto da membrana plasmática (microvilosidades de células do intestino), quanto das membranas de organelas intracelulares (retículo endoplasmático e mitocôndrias). (b) Fosfolipídeos das membranas plasmáticas de células procarióticas. Abreviações das cabeças polares: esfingomielina (SM, \pm ) fosfatidilcolina( $P C, \pm$ ), fosfatidiletanolamina ( $P E, \pm$ ), fosfatidilserina, (PS, - ), fosfatidilinositol (PI,-) ácido fosfatídico ( $P A,-)$, cardiolipina $(C L,-)$, fosfatidilglicerol $(P G,-)$. A soma das porcentagens nem sempre chegam a $100 \%$ devido a constituintes minoritários variados.

(a)

\begin{tabular}{|c|c|c|c|c|c|}
\hline \multirow{3}{*}{$\begin{array}{c}\text { EUCARIOTOS } \\
\text { Mamíferos }\end{array}$} & \multicolumn{5}{|c|}{ Percentual entre os fosfolipídeos (\%) } \\
\hline & \multicolumn{3}{|c|}{ Zwitteriônicos ( \pm ) } & \multicolumn{2}{|c|}{ Aniônicos (-) } \\
\hline & SM & PC & PE & $\begin{array}{c}\text { (todos) } \\
\text { PS + PI + PA }\end{array}$ & $\mathrm{CL}$ \\
\hline $\begin{array}{l}\text { Microvilosidades de células } \\
\text { do intestino pequeno de } \\
\text { Coelho }\end{array}$ & 16 & 39 & $\begin{array}{c}23^{i} \\
\text { (só folheto interno) }\end{array}$ & 18 & 1 \\
\hline $\begin{array}{l}\text { Retículo endoplasmático de } \\
\text { células do músculo } \\
\text { esquelético de coelhos }\end{array}$ & 1 & 72,7 & 13,5 & 10,5 & $<1$ \\
\hline $\begin{array}{l}\text { Mitocôndrias de células do } \\
\text { fígado de ratos }\end{array}$ & 1 & 40 & 35 & 6 & 18 \\
\hline
\end{tabular}

(b)

\begin{tabular}{|c|c|c|c|c|c|}
\hline \multirow{3}{*}{$\begin{array}{c}\text { PROCARIOTOS } \\
\text { Bactérias } \\
\text { Gram Negativas }\end{array}$} & \multicolumn{5}{|c|}{ Percentual entre os fosfolipídeos (\%) } \\
\hline & \multicolumn{3}{|c|}{ Zwitteriônicos ( \pm ) } & \multicolumn{2}{|c|}{ Aniônicos (-) } \\
\hline & SM & PC & PE & PG & $\mathrm{CL}$ \\
\hline Escherichia coli & - & - & 80 & 15 & - \\
\hline Pseudomonas aeruginosa & - & - & 60 & 21 & 11 \\
\hline Proteus mirabilis & - & - & 80 & 10 & 5 \\
\hline Caulobacter crescentus ii & - & - & - & 40 & - \\
\hline Enterobacter cloacae & - & - & 80 & 21 & 3 \\
\hline Yersinia kristensenii & - & - & 60 & 20 & 20 \\
\hline Klebsiella pneumoniae & - & - & 82 & 5 & 6 \\
\hline
\end{tabular}

\begin{tabular}{|c|c|c|c|c|c|}
\hline \multirow{3}{*}{$\begin{array}{c}\text { PROCARIOTOS } \\
\text { Bactérias } \\
\text { Gram Positivas }\end{array}$} & \multicolumn{5}{|c|}{ Percentual entre os fosfolipídeos (\%) } \\
\hline & \multicolumn{3}{|c|}{ Zwitteriônicos ( \pm ) } & \multicolumn{2}{|c|}{ Aniônicos (-) } \\
\hline & \multicolumn{2}{|c|}{ PC } & PE & PG & CL \\
\hline Staphylococcus aureus & - & - & 0 & 58 & 42 \\
\hline Streptococcus pneumoniae & - & - & 0 & 50 & 50 \\
\hline Bacillus cereus & - & - & 43 & 40 & 17 \\
\hline Bacillus anthracis & - & - & 43 & 40 & 17 \\
\hline Bacillus polymyxa & - & - & 60 & 3 & 8 \\
\hline Bacillus subtilis & - & - & 12 & 70 & 4 \\
\hline Streptococcus pyogenes & - & - & Traços & - & $\begin{array}{c}\text { Componente } \\
\text { Majoritário }\end{array}$ \\
\hline
\end{tabular}

Fonte: Adaptada de YEAGLE ${ }^{76}$; EPAND; EPAND ${ }^{82}$; EPAND; SAVAGE; EPAND ${ }^{83}$.

\footnotetext{
'PE não está exposto ao ambiente. Todos estão na monocamada interna (voltada para dentro da célula).

ii PE e CL não foram detectados. O maior componente lipídico (45\%) desta bactéria é o monoglicosildiglicerídeo.
} 


\subsection{MODELOS DE MEMBRANA CELULAR}

Como brevemente já discutido, as membranas biológicas são sistemas extremamente complexos, que tem composição química variada e dinâmica própria, capazes de responder a diversos estímulos extra/intracelulares. Há, desta forma, uma infinidade de parâmetros importantes que regulam simultaneamente a resposta da interação molecular delas com o meio. Visando obter um controle maior do sistema para realizar um estudo detalhado das interações moleculares, o uso de modelos simplificados de membranas é essencial (FIGURA 15). ${ }^{68,94}$ Tais sistemas simplificados mantêm algumas propriedades principais das membranas, mas deixam de lado outras. Cada modelo tem suas vantagens e desvantagens e, portanto, uma mesma investigação usando os vários diferentes modelos seria ideal.

FIGURA 15 - PRINCIPAIS MODELOS DE MEMBRANA. (a) Lipossomo (bicamada lipídica em meio aquoso); (b) Filmes de Langmuir-Blodgett (bicamadas sobre subtrato sólido); (c) Filmes de Langmuir (monocamada lipídica sobre subfase aquosa).

\section{(a) Lipossomo}

\section{Modelos de Membrana}
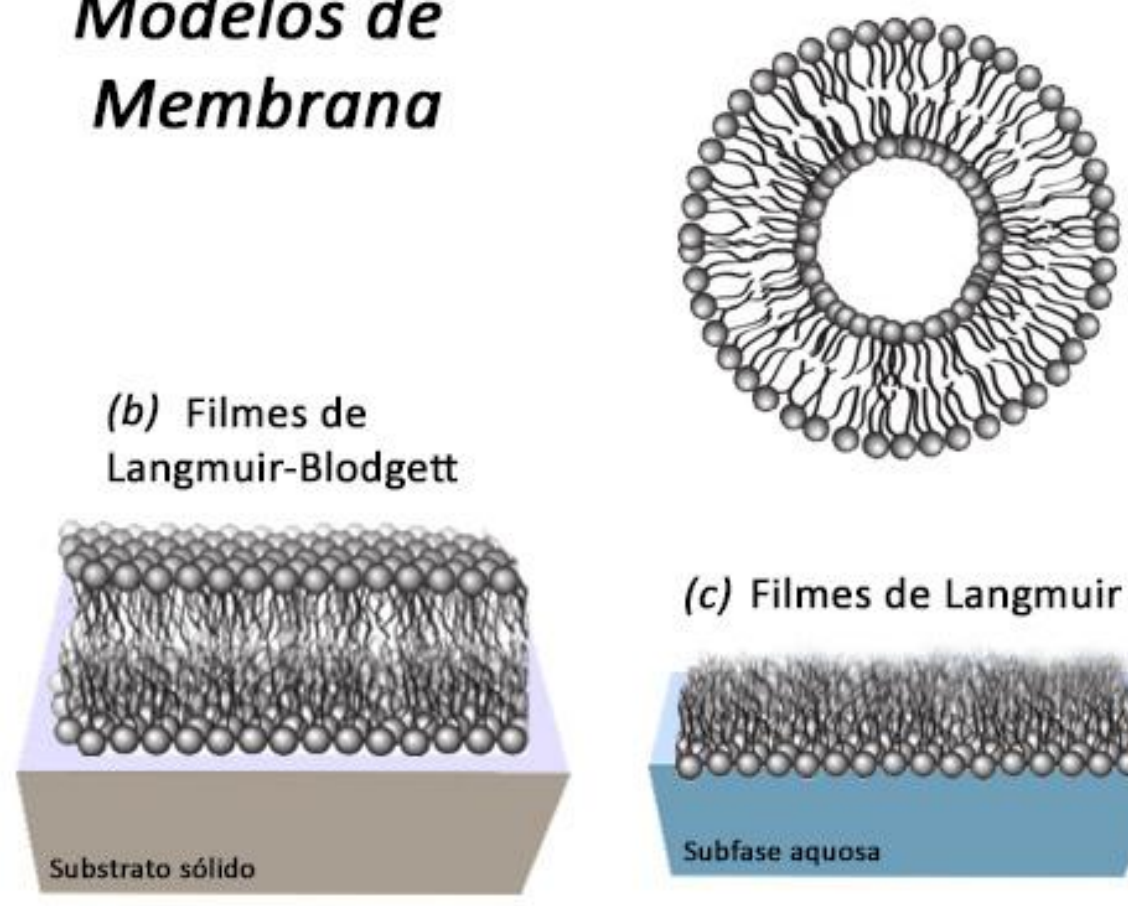

(c) Filmes de Langmuir

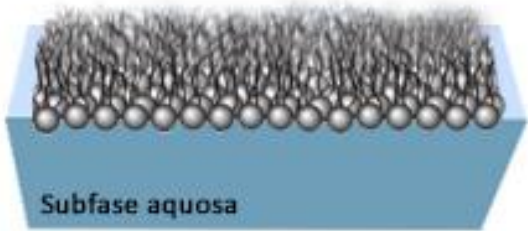

Fonte: Adaptada de DREIER. ${ }^{95}$ 


\subsubsection{Lipossomos}

Lipossomos são os modelos mais utilizados para mimetizar membranas biológicas. Eles formam uma dispersão coloidal de vesículas lipídicas, que são estruturas semelhantes a cascas esféricas compostas por bicamadas lipídicas (FIGURA 15.a). Uma vesícula pode ser unilamelar (conter apenas uma bicamada lipídica) ou multilamelar (conter várias dessas bicamadas concêntricas). 0 tamanho típico destas partículas varia entre $30 \mathrm{~nm}$ a alguns micrômetros. ${ }^{96-97}$ e a distribuição de tamanhos varia de caso a caso. Uma das principais aplicações de lipossomos é como veículos de entrega de drogas (Drug Delivery), pois podem transportar medicamentos lipossolúveis no cerne hidrofóbico das lamelas ou medicamentos hidrossolúveis no volume aquoso em seu interior (FIGURA 15.a). ${ }^{96}$ Dentre os modelos de membrana convencionais, eles se destacam por apresentarem uma bicamada lipídica com curvatura (como acontece nas células) e por permitirem a difusão lateral dos lipídeos nas bicamadas (livres para se difundir nas lamelas). Por manter essas duas propriedades, os lipossomos são considerados por muitos o melhor modelo de membranas biológicas. Entretanto, tais cascas lipídicas são coloides liofóbicos (termodinamicamente instáveis, não permanecendo em um mesmo estado de equilíbrio), pois estão sempre colidindo e se coalescendo com o tempo, alterando seu tamanho e, consequentemente, sua curvatura. ${ }^{97}$ Logo, a distribuição inicial de partículas tende à total separação de fase. A composição lipídica influencia drasticamente a estabilidade cinética (tempo de meia vida) dessas nanoestruturas. Portanto, uma de suas principais limitações é justamente a impossibilidade de formar lipossomos com quaisquer misturas/proporções lipídicas. Em certos casos, obtém-se uma distribuição de tamanhos muito larga (partículas de tamanho médio pouco representativo) ou simplesmente não há a formação de tais estruturas. Outro detalhe é que os lipídeos mais usados para a formação de lipossomos são facilmente degradáveis (possuem cadeias carbônicas insaturadas na porção apolar da molécula que são vulneráveis à oxidação). Ademais, é impossível controlar a densidade de compactação lipídica independente de sua composição. Mais do que isso, o estado físico de duas dispersões lipídicas de mesma composição depende do método de preparação. ${ }^{96,98}$ Em dispersões constituídas de mais de um tipo lipídico, a proporção de lipídeos de cada vesícula é desconhecida (obtém-se um valor médio) e nem sempre as partículas são esféricas. Por isso, a área média por lipídeo exposto ao meio também não 
é conhecida, a não ser que a geometria exata das vesículas na dispersão seja determinada. Por fim, dispersões coloidais tem um número menor de possíveis técnicas de caracterização label-free (sem a adição de marcadores, que podem perturbar o sistema) quando comparadas a outros modelos (planares) de membrana, como os Filmes de Langmuir e Filmes de Langmuir-Blodgett.

\subsubsection{Filmes de Langmuir-Blodgett}

Filmes de Langmuir-Blodgett (LB) são filmes de lipídeos estruturados em mono/multicamadas suportados (presos) por um substrato sólido (FIGURA 15.b).94,97 Logo, tem-se o controle da composição lipídica camada por camada. Portanto, é possível elaborar bicamadas lipídicas assimétricas, como ocorre em sistemas vivos. Além disso, como o Filme LB está preso a um subtrato sólido, há a possibilidade de transportá-lo para diversos locais a fim de realizar uma caracterização diversificada, com as mais diferentes técnicas. Entretanto, os lipídeos por estarem adsorvidos ao substrato, tem difusão lateral limitada, principalmente na primeira monocamada, junto ao substrato. ${ }^{98}$ Desta forma, eventuais efeitos dinâmicos de formação de domínios ou expansão/compactação da membrana não podem ser detectados com este modelo.

\subsubsection{Filmes de Langmuir}

Filmes de Langmuir são membranas artificiais constituídas de apenas uma monocamada planar de lipídeos "flutuantes" na interface água-ar(FIGURA 15.c). Ou seja, as monocamadas lipídicas modelam somente metade de uma membrana em contato com uma subfase aquosa. Logo, de imediato, presume-se que as eventuais desvantagens deste modelo estão relacionadas à ausência do segundo folheto lipídico e do ambiente aquoso do outro lado da membrana. Entretanto, tal modelo de membrana é superior a outros por não sofrer uma série de limitações, sobretudo das descritas anteriormente. ${ }^{98}$ Por ser um modelo planar de membrana, a geometria do sistema já é determinada e a área por lipídeo exposta à subfase aquosa é simples de se obter (o que facilita na elaboração de modelos teóricos para comparar com os resultados experimentais). Existem estudos que relacionam os efeitos de expansão/compactação medidos na 
monocamada de Langmuir com outros modelos de bicamadas lipídicas. ${ }^{98-100}$ Além disso, não há a necessidade da curvatura da membrana e, por esta razão, é possível trabalhar com um número maior de tipos lipídicos do que em lipossomos. Ademais, é possível fazer diversos experimentos que exploram a termodinâmica do sistema justamente porque se tem o controle do grau de compactação de um determinado filme lipídico. Logo, é possível extrair várias informações de um dado sistema sem precisar alterar a composição química do filme. Por exemplo, as isotermas de um Filme de Langmuir fornecem uma série de informações como grau de interação/afinidade que um composto na subfase com o filme lipídico na interface devido. ${ }^{97-98} \mathrm{~A}$ estabilidade do filme diante de diferentes composições de subfase pode ser medida analisando as mudanças no valor da pressão de colapso, que ocorre quando o filme está extremamente compactado. Por outro lado, é possível verificar se esse composto na subfase destrói ou não o filme lipídico por solubilização (efeito detergente). Enfim, dependendo de como se elabora o experimento (pressão constante, área constante, temperatura constante, etc) são obtidas diferentes informações da membrana artificial. Além de todas essas vantagens, uma das principais características deste modelo é que os lipídeos estão livres para se difundir na monocamada, como em uma biomembrana. Assim, se o filme é composto por uma mistura lipídica, uma molécula adicionada na subfase pode interagir com o filme e causar separação de fase na interface. Em particular, esta é a principal vantagem deste modelo frente a Filmes de Langmuir-Blodgett. Neste trabalho, nós usamos Filmes de Langmuir como modelo de membrana, pois queríamos usufruir de todas essas vantagens acima e precisávamos um modelo planar de membrana para medir o espectro vibracional do sistema com a técnica de Espectroscopia Vibracional Não Linear por Geração de Soma de Frequências (Espectroscopia SFG).68-74 Embora na literatura já tenha sido descrito um experimento de Espectroscopia SFG por espalhamento, que é capaz de investigar a interface de partículas coloidais,101 tais experimentos são extremamente complexos e, até o momento, somente um grupo de pesquisa no mundo tem a infraestrutura para realizá-los. 


\subsection{CONCEITOS BÁSICOS EM TERMODINÂMICA DE SUPERFÍCIES LÍQUIDAS}

\subsubsection{Tensão Superficial $(\gamma)$}

Em um meio líquido, as moléculas que o compõem tem um grau atração entre si. ${ }^{94,97}$ Isso se torna óbvio ao imaginar a situação contrária: se as moléculas de um líquido causassem mais repulsão do que atração entre elas, tais moléculas não formariam um meio coeso, mas sim um gás. 0 grau de atração entre as moléculas de um líquido é denominado coesão e esta propriedade varia de substância para substância. Uma consequência imediata da coesão é observada em superfícies/interfaces. Por exemplo, em uma interface líquido-ar em particular, as moléculas do líquido que definem esta fronteira sofrem uma força atrativa resultante que aponta para o cerne tridimensional (bulk) do líquido (FIGURA 16.a). Isso acontece visto que é somente nesta direção que há outras moléculas puxando (tensionando) as moléculas interfaciais. Desta forma, moléculas que constituem a fronteira de um líquido querem sempre fugir da fronteira em direção ao interior, causando a compactação do material. Logo, um líquido tende sempre a minimizar razão superfície/volume.

FIGURA 16 - TENSÃO SUPERFICIAL. (a) Moléculas que constituem um líquido e suas respectivas interações. As setas negras ilustram interações atrativas (coesivas); a seta vermelha ilustra o sentido da resultante de forças coesivas que atuam nas moléculas interfaciais do líquido. (b) Ilustração de como seria o comportamento das moléculas interfaciais caso se tentássemos afastar as moléculas da região $A B M^{\prime} M$ das moléculas vizinhas em $C D M M^{\prime}$. Note que no ponto $P$ há uma tensão

(a) perpendicular ao elemento de comprimento $\delta l$, que é a tensão superficial $(\gamma)$ no ponto $\mathrm{P}$.

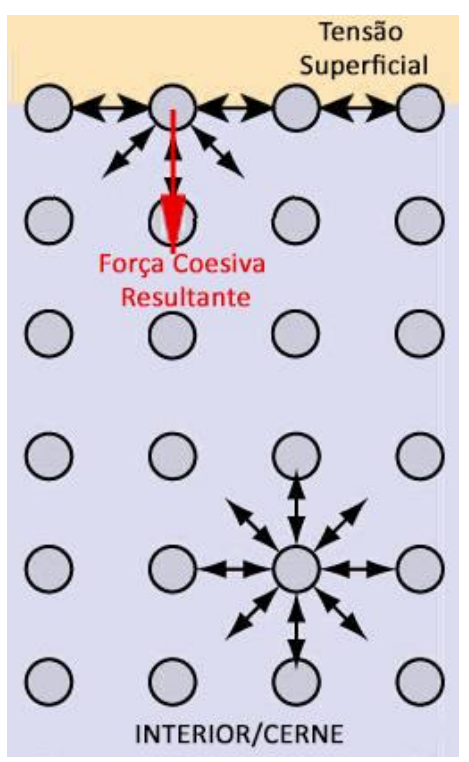

(b)

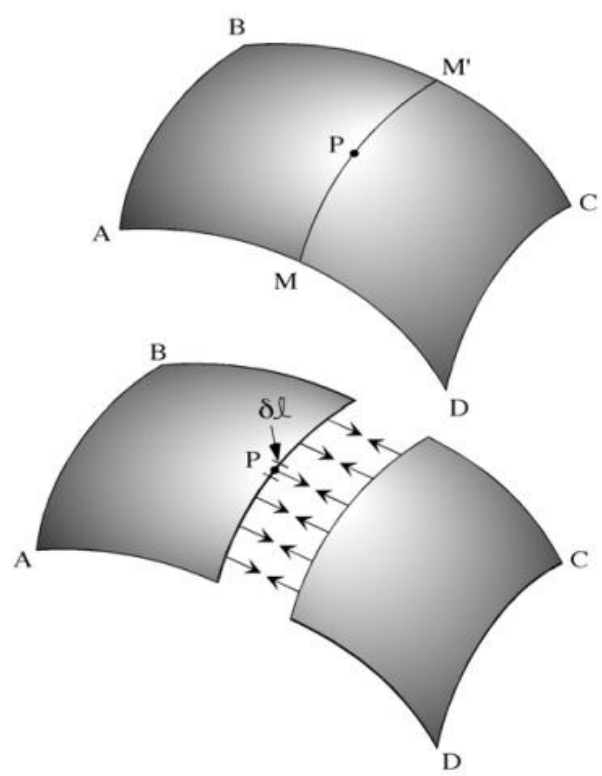

Fonte: (a) Elaborada pelo autor; (b) BERG ${ }^{97}$. 
Na FIGURAS 16.a e 16.b, a força atrativa por unidade de comprimento no plano da interface é denominada Tensão Superficial $(\gamma)$, cuja unidade tipicamente usada na literatura é $[\mathrm{mN} / \mathrm{m}]$. A Tensão Superficial pode ser expressa em termos das derivadas parciais das energias livres do sistema com respeito à área superficial (A):

$$
\gamma=\left(\frac{\partial G}{\partial A}\right)_{T, P, n_{i}}
$$

Em que G é a energia livre de e Gibbs da interface. ${ }^{97,102}$ A expressão em um líquido puro, corresponde a:

$$
\gamma_{0}=\frac{\text { Energia Livre da superfície }}{\text { Área Total }}
$$

A tensão superficial geralmente diminui com o aumento da temperatura.97,99100,102 Líquidos polares, como a água, tem interações intermoleculares muito fortes e, consequentemente, um alto valor de tensão superficial. Em particular, a tensão superficial da água a $20^{\circ} \mathrm{C}$ é $\gamma_{H_{2} O}=72,8 \mathrm{mN} / \mathrm{m}$, um valor extremamente alto comparado a outros líquidos na mesma temperatura (tipicamente $\sim 25 \mathrm{mN} / \mathrm{m}$ ).

\subsubsection{Pressão Superficial ( $\pi$ )}

Quando substâncias anfifílicas (com regiões polares e apolares) são adicionadas em meios aquosos, elas tendem a se adsorver nas interfaces, liberando várias moléculas interfaciais de água para o interior do volume. Tal substituição molecular altera o grau de coesão das moléculas da interface. Moléculas com tal propriedade de "substituição" são denominadas surfactantes. Como a água em geral tem um valor de tensão superficial muito grande, um surfactante ao adsorver na interface aquosa diminui a tensão superficial do líquido, pois a interface passa a ser menos povoada por moléculas de água. Logo, a redução da tensão superficial de um líquido pode ser definida como uma Pressão Superficial $(\pi)$, pois é como se os surfactantes adsorvidos na interface causassem uma pressão bidimensional na superfície que reduz a coesão inicial devido às moléculas de água: 


$$
\pi \equiv \gamma_{0}-\gamma
$$

Em que $\gamma_{0}$ é a tensão superficial do líquido puro (sem a adição de surfactantes) e $\gamma$ é a tensão superficial do líquido com surfactante.

\subsubsection{Princípio do Método de Wilhelmy para medir Pressão Superficial}

Há diversos tipos de métodos capazes de medir a redução da tensão superficial. Como nós vamos usar a Cuba de Langmuir, este equipamento usa o método da Placa de Wilhelmy ilustrado abaixo (FIGURA 17).102

FIGURA 17 - MÉTODO DE WILHELMY.

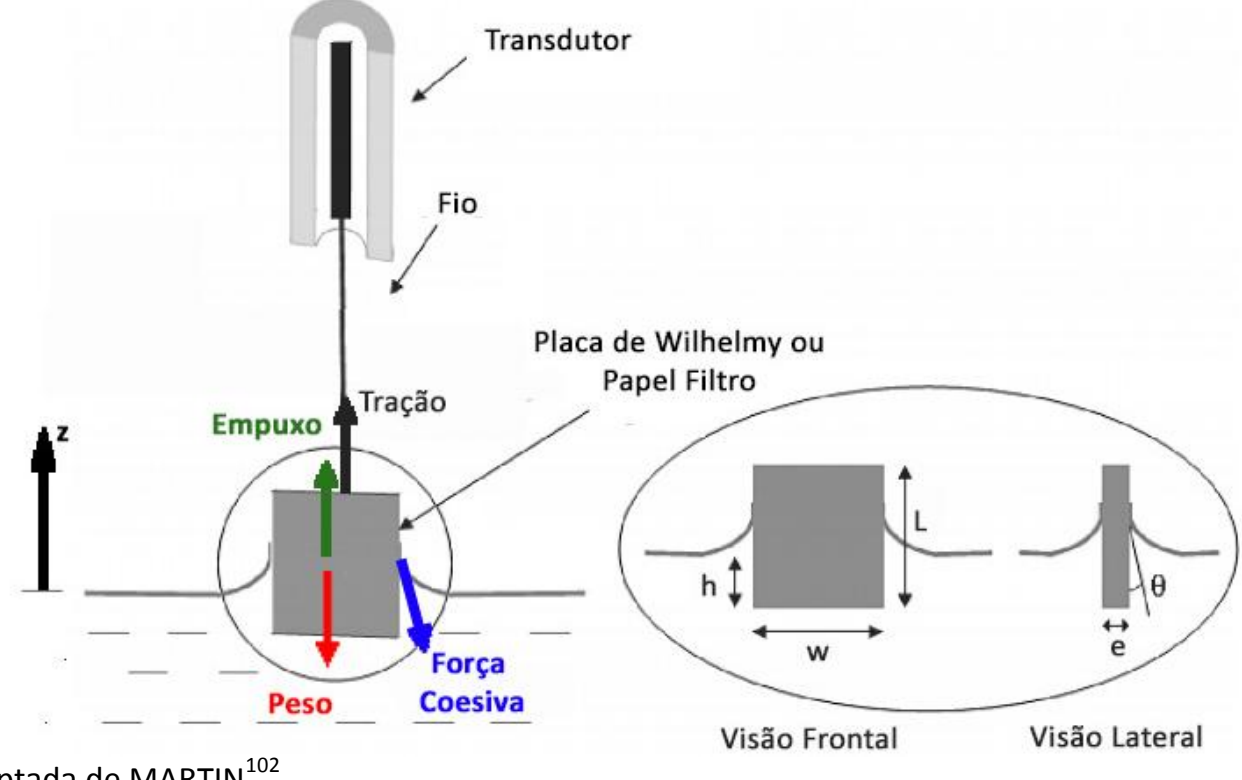

Fonte: Adaptada de MARTIN ${ }^{102}$.

Aqui, ao medirmos diferença das trações diante duas as condições diferentes (com subfase pura e com os agentes surfactantes), obtemos a o valor da pressão superficial causada pelos surfactantes. Considere a condição de equilíbrio de forças quando a subfase é água pura. Ao projetarmos as forças no eixo-z, temos:

$$
T_{0}=P+2 F_{c o} \cdot \cos \theta_{0}-E
$$

Ou seja, 


$$
T_{0}=P+2 \gamma_{0}(e+w) \cos \theta_{0}-E
$$

Em que $\mathrm{T}_{0}$ é a tração medida pelo experimento, $\mathrm{P}$ o peso da placa, $\mathrm{E}$ o empuxo, $\mathrm{F}_{\text {co }}$ as forças coesivas que puxam o sensor (placa) para dentro da subfase, g é a constante de gravidade, $\theta_{0}$ é o ângulo de contato entre a placa e o líquido, $e$ é a espessura da placa, $\mathrm{w}$ a largura da placa e h é o quão imersa está a placa. Já a condição de equilíbrio de forças quando a subfase é com a adição de surfactantes (lipídeos), temos:

$$
T_{m}=P+2 \cdot F_{c o}^{m} \cdot \cos \theta_{m}-E
$$

Ou seja,

$$
T_{m}=P+2 \gamma(e+w) \cos \theta_{m}-E
$$

Em que $\mathrm{T}_{\mathrm{m}}$ é a nova tração medida e $\theta_{m}$ é o novo ângulo de contato.

Medindo a redução da tração no fio devido à presença do surfactante (considerando h $\approx$ constante):

$$
\Delta T=T_{0}-T_{m}=2(e+w)\left(\gamma_{0} \cos \theta_{0}-\gamma \cos \theta_{m}\right)
$$

Como a nossa placa é extremamente hidrofílica e está totalmente molhada, ambos os ângulos de contato são muito próximos de zero e os cossenos podem ser aproximados para 1:

$$
\Delta T=T_{0}-T_{m} \cong 2(e+w)\left(\gamma_{0}-\gamma\right)
$$

Se placa for extremamente fina $(e<<w)$, então:

$$
\Delta T=T_{0}-T_{m} \cong 2 w\left(\gamma_{0}-\gamma\right)=2 w \Delta \gamma
$$

Usando a definição de pressão superficial (Equação 3), chegamos finalmente a:

$$
\pi=\Delta \gamma=\frac{\Delta T}{2 w}
$$




\subsection{A CUBA DE LANGMUIR}

Filmes de Langmuir (FL) Lipídicos são membranas modelo que simulam metade de uma membrana biológica. Eles consistem em uma monocamada lipídica que permanecem exclusivamente na interface ar-líquido. Para a formação desta monocamada, utiliza-se um equipamento chamado Cuba de Langmuir (FIGURA 18).103 Para formar uma membrana modelo, preparam-se previamente alguns poucos mL de uma solução de lipídeo de interesse em solvente apolar volátil (tipicamente clorofórmio) e centenas de $\mathrm{mL}$ das possíveis subfases aquosas (água Milli-Q ultrapura, soluções de polímero antimicrobiano em diferentes concentrações, etc). A subfase aquosa de interesse deve preencher todo volume da cuba (um recipiente confeccionado de material inerte, como teflon). Em seguida, apenas alguns $\mu \mathrm{L}$ da solução lipídica são espalhados sobre a superfície da subfase. Antes de iniciar os experimentos, é preciso esperar o solvente apolar se volatilizar totalmente. Em particular, a Cuba de Langmuir que utilizamos tinha capacidade para $115 \mathrm{~mL}$ de subfase. A cuba possui barreiras móveis que podem comprimir as moléculas lipídicas no espaço entre elas. Ela também tem detectores de posição das barreiras, para determinar a área de superfície do filme ponto a ponto. Como se conhece previamente a quantia de lipídeo espalhado, a área disponível por molécula de lipídeo na interface $(\sigma)$ é imediatamente calculada. Além disso, um sensor de pressão superficial mede pelo Método de Wilhelmy a diferença entre a tensão superficial da subfase pura e a tensão da interface contendo o filme.

FIGURA 18 - CUBA DE LANGMUIR. Legenda: 1 suporte; 2 barreiras de delrin; 3 cuba de teflon; 4 microbalança (sensor de tensão); 5 mecanismo de mergulho de substratos para a formação de filmes LB; 6 unidade de controle de aquisição de dados. Dimensões da nossa cuba: $34,0 \mathrm{~cm} \times 5,0 \mathrm{~cm} \times$ $0,5 \mathrm{~cm}$.

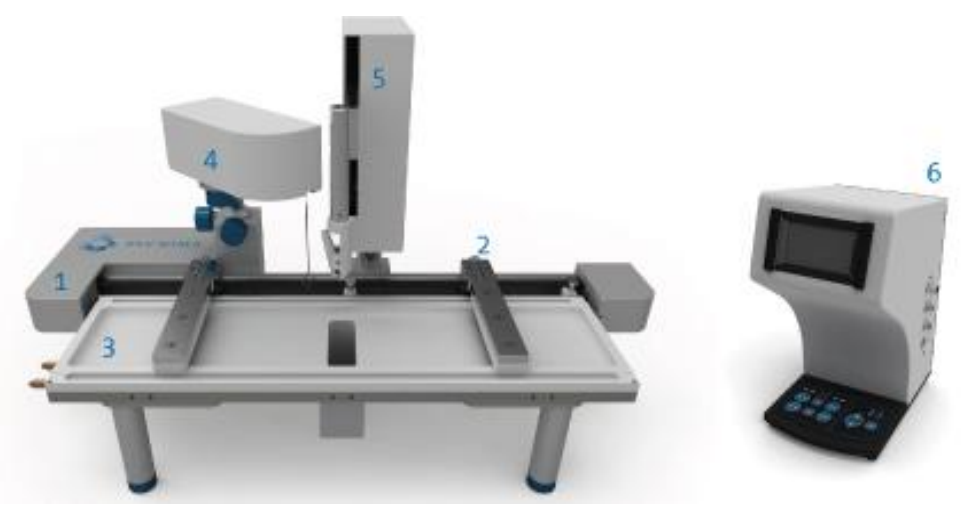

Fonte: BIOLIN... ${ }^{103}$ 


\subsubsection{Membranas Biomiméticas: Pressões de Relevância Biológica}

O conceito de pressão de superfície em membranas biológicas (reais) é muito menos claro de ser definido do que no caso das Monocamadas de Langmuir (modelos planares). Isso se deve ao fato de que as membranas biológicas estão naturalmente em um estado livre de tensão superficial. Entretanto, seria interessante ter uma noção de quais pressões superficiais nas Monocamadas de Langmuir seriam as mais representativas das membranas biológicas reais. Isto é, qual o grau de compactação lipídico modelaria bem o sistema real. Em particular, em um trabalho detalhado de Derek Marsh de 1996, intitulado "Lateral pressure in membranes", Marsh faz uma série de estudos comparativos e defende a tese de que pressões superficiais $(\pi)$ entre $\mathbf{3 0 m N} / \mathbf{m}$ e $35 \mathbf{m N} / \mathbf{m}$ de Filmes de Langmuir de Fosfolipídeos são os modelos mais biologicamente relevantes, pois representam bem o grau de compactação lipídica da situação real das membranas celulares. ${ }^{100}$

\subsubsection{Metodologia \#1: Compressão Isotérmica (Diagrama $\pi-\sigma$ )}

Um experimento termodinâmico típico feito com este equipamento é compressão isotérmica (FIGURA 19).103 Ele nos fornece gráficos de Pressão Superficial VS Área disponível por molécula (diagrama $\pi-\sigma$, o análogo bidimensional do diagrama P-V para um sistema tridimensional). A comparação das curvas $\pi-\sigma$ de um tipo de filme lipídico com diferentes subfases (diferentes soluções de antimicrobianos, por exemplo) fornece informações macroscópicas da interação entre os antimicrobianos e o filme. Por exemplo, um antimicrobiano pode causar expansão ou destruição (solubilização/micelização) daquela membrana modelo em específico. 
FIGURA 19 - EXPERIMENTO DE COMPRESSÃO ISOTÉRMICA. O gráfico esquemático à esquerda representa uma isoterma (curva $\pi-\sigma$ ). Ao centro, ilustração da respectiva compressão. Note que o empacotamento da monocamada lipídica desencadeia um aumento de $\pi$. As Letras $S, L_{1} L_{2}$ e $G$ esquematizam algumas eventuais fases (sólida, líquida-1, líquida-2 e gasosa respectivamente). Note também que o processo $L_{1} G$ representa uma transição da fase gás para a líquida-1. À direita, uma ilustração tridimensional de dois diferentes graus de compactação do Filme de Langmuir (lipídeos em cinza e subfase em azul).

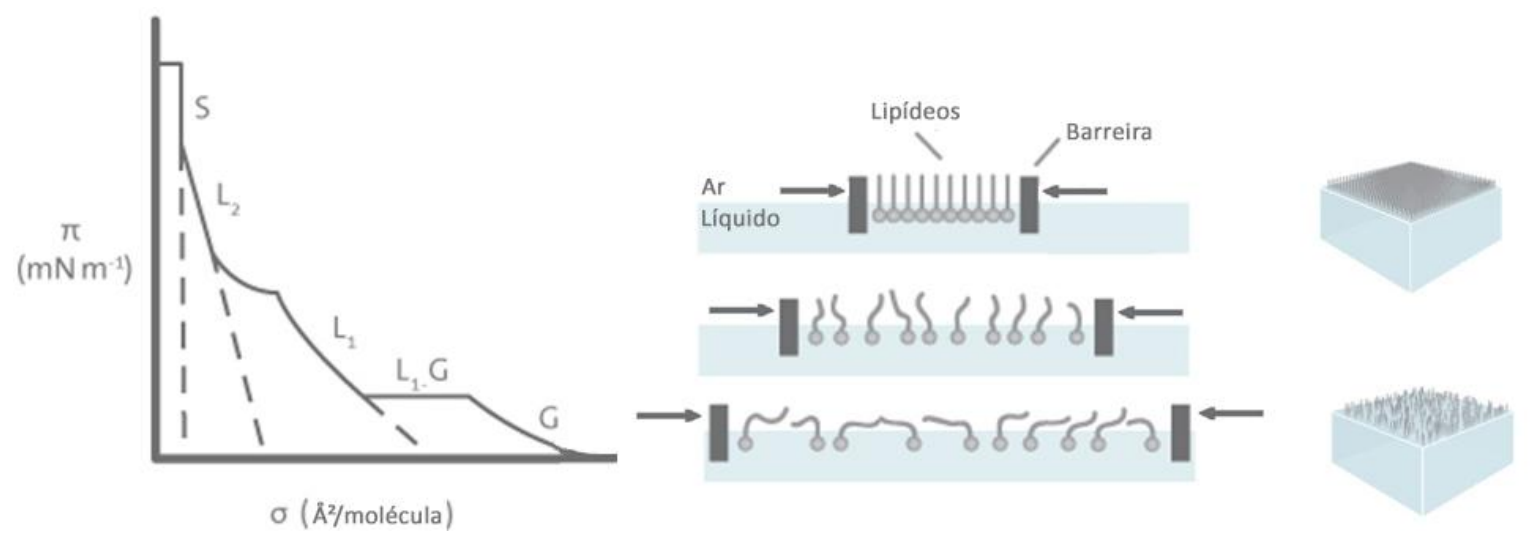

Fonte: Adaptada de BIOLIN.... ${ }^{103}$

Inicialmente, com as barreiras totalmente abertas, os lipídeos são espalhados na superfície aquosa na região entre as barreiras. A quantidade de lipídeos espalhada é muito pequena, de modo que eles ficam dispersos na interface sem interagir entre si (definida como fase gasosa). ${ }^{102}$ Conforme as barreiras começam a se mover reduzindo a área por molécula disponível $(\sigma)$, os lipídeos começam a interagir entre si, passando a uma fase fluida diferente (fase líquido-expandida) e, em seguida, são forçadas a formar um arranjo regular, formando o filme condensado (fase condensada). Cada fase desse fluido na interface apresenta uma inclinação típica na curva do diagrama $\pi-\sigma$. Quanto mais condensadas as fases, maior será a inclinação da isoterma, visto que mais água é expelida da interface - ou, analogamente, mais difícil de comprimir por causa do aumento da pressão superficial. Chega um momento em que o grau de compressão é tão grande que o filme se colapsa: ${ }^{102,103}$ os lipídeos deixam de formar uma única monocamada sobre a água e passam a formar nanoestruturas aleatórias no ar (FIGURA 20). Note que os lipídeos utilizados são insolúveis em meio aquoso. Assim, eles não devem migrar para subfase durante a compressão, sobretudo quando a subfase em questão for água pura. 
FIGURA 20 - COLAPSO DE UM FILME DE LANGMUIR. No colapso, os lipídeos que antes formavam somente uma monocamada sobre superfície aquosa, começam a formar agregados ou multicamadas sobre a subfase e que são não reprodutíveis (a cada colapso, a estrutura resultante pode ser diferente).

\section{Monocamada Colapsada}

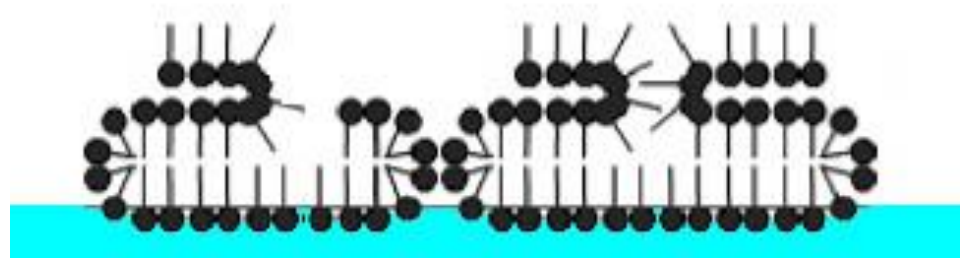

Fonte: Adaptada de MARTIN ${ }^{102}$.

Observação importante: note que, em experimentos que visam investigar o efeito de antimicrobianos na membrana modelo usando esta metodologia, os antimicrobianos já estão solubilizados na subfase antes mesmo de se espalhar os lipídeos na cuba.

Em particular, as perguntas que queremos responder usando esta metodologia são: o antimicrobiano da subfase se adsorve na interface depois de espalharmos o lipídeo? Se sim, como ele interage com o filme no decorrer da compressão isotérmica? Expandindo/Destruindo o filme? Muito ou pouco? Durante a formação da monocamada diante de uma alta compressão, o antimicrobiano permanece na interface? Até que ponto? Ou seja, qual o grau de afinidade que o antimicrobiano tem pelo lipídeo utilizado na interface líquido-ar?

Além disso, quando a subfase é água pura, esse experimento também permite testar a qualidade dos fosfolipídeos espalhados na interface visto que a isoterma é muito sensível à contaminação (tanto da solução lipídica quanto da subfase). 0 diagrama $\pi-\sigma$ da compressão isotérmica de um dado filme lipídico $\mathrm{X}$, em uma subfase $\mathrm{Y}$ à temperatura T é extremamente reprodutível (se os cuidados adequados de limpeza forem tomados, FIGURA 21). 


\subsubsection{Interpretação do Diagrama $\pi-\sigma$}

Visando explicar como interpretar um diagrama $\pi-\sigma$ e de como a curva é sensível às mudanças de composição na interface, analisaremos a FIGURA 21, que mostra a rotina experimental de um experimentador que quer descobrir como é o perfil de uma isoterma de DPPC sobre uma subfase de Tampão Tris. Esses experimentos foram feitos em sequência na Sala Limpa do Grupo de Polímeros prof. "Bernhand Gross" do IFSC/USP a uma temperatura de $20^{\circ} \mathrm{C}$.

FIGURA 21 - EXEMPLO DE EXPERIMENTOS DE COMPRESSÃO ISOTÉRMICA. Esta sequência de experimentos foi
realizada em um único dia. No começo do dia (experimentos \#1, \#2 e \#3), o experimentador
começa com um sistema já conhecido pela literatura (isoterma de DPPC em água pura).
Baseando-se nas curvas \#1 e \#2, o experimentador consegue corrigir os eventuais problemas
experimentais e em \#3 ele tem a garantia de está tudo certo. Em \#4 ele investiga o sistema novo
e em \#5 ele repete o experimento desconhecido, por garantia. Note como \#5 reproduz bem o
resultado de \#4 de $\pi=0 \mathrm{mN} / \mathrm{m}$ até $\pi=60 \mathrm{mN} / \mathrm{m}$, quando o filme se colapsa e, a partir daí, os
resultados são irreprodutíveis

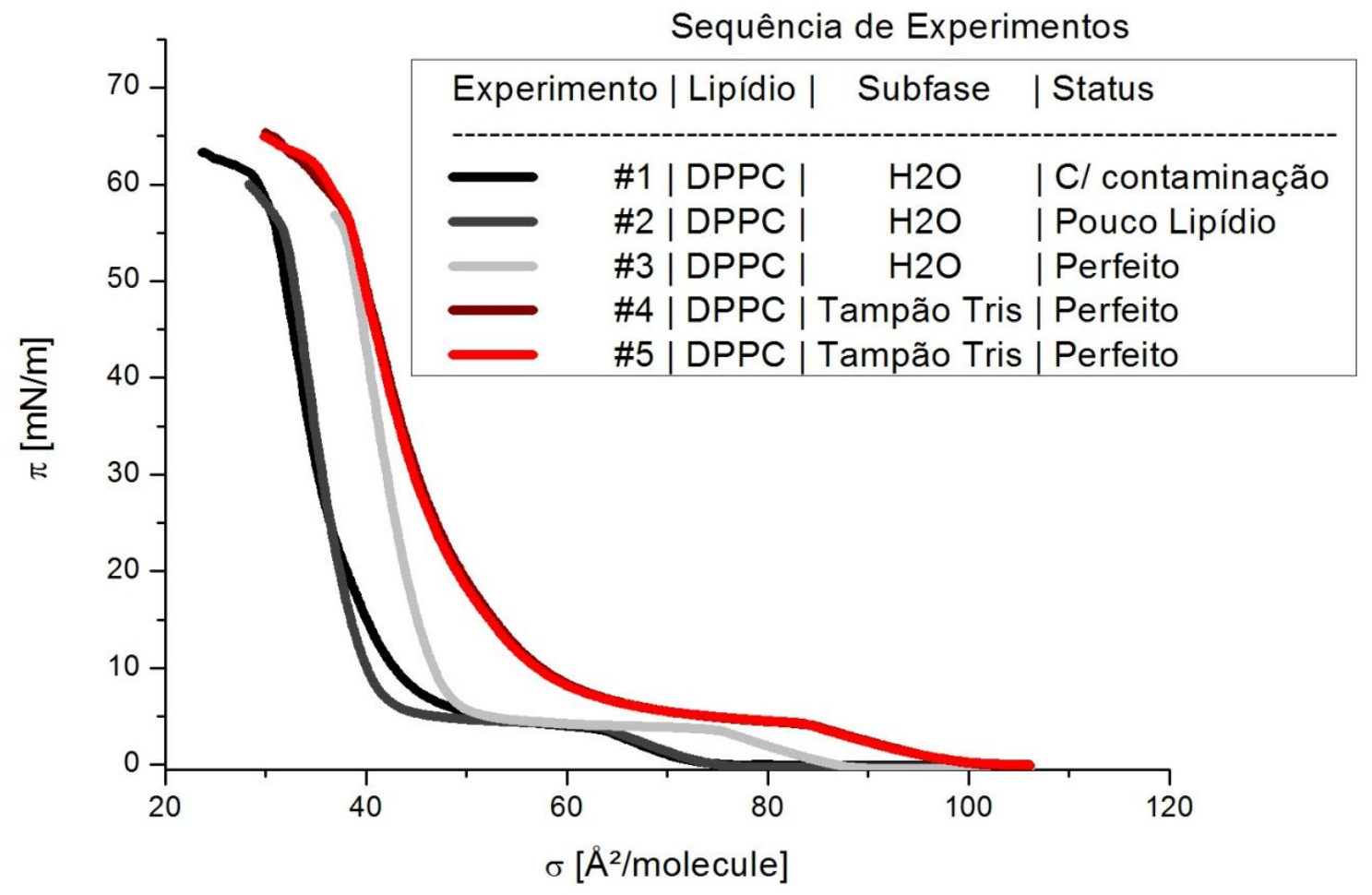

Fonte: Elaborada pelo autor.

Os experimentos \#1, \#2 e \#3 são de DPPC em Água Pura, sendo que só em \#3 se obteve a isoterma correta (que é idêntica a da literatura). Exp\#1, linha preta, precisa corrigir duas coisas: a concentração de lipídeo espalhada (está deslocada à esquerda, um indicativo de que há menos lipídeo na interface do que se imaginava) e há contaminação no sistema (a forma da isoterma é diferente da correta, em cinza). Até então, a origem da 
contaminação é desconhecida: pode ser do teflon da cuba, da solução lipídica ou da subfase. 0 exp\#2 é a repetição de \#1, sendo que houve uma limpeza mais minuciosa do teflon da cuba, o qual corrigiu o problema de contaminação (i.e., o teflon da cuba que estava sujo). Só resta agora corrigir a quantidade de DPPC espalhada. Após corrigir a quantidade de DPPC a ser espalhado, o Exp\#3 tem o resultado idêntico ao da literatura tudo certo para dar continuidade e testar com a subfase desconhecida. Exp\#4 é a isoterma de DPPC em Tampão e o Exp\#5 é a confirmação de que \#4 era o resultado correto - isoterma reprodutível.

Note também que as curvas de DPPC quando a subfase é tampão (Exp\#4 e \#5) estão deslocadas para a direita em relação à curva do Exp\#3, que serve como controle. Tal comportamento pode ser entendido como uma expansão do filme de DPPC na presença do composto orgânico Tris. Repare em $\pi=10 \mathrm{mN} / \mathrm{m}$ como esse aumento na área disponível por molécula $(\sigma)$ fica bem nítido. Observe em Exp\#4 e \#5 que quando $\pi \approx 60 \mathrm{mN} / \mathrm{m}$ as isotermas começam a não ter mais resultados tão reprodutíveis, que é consequência do colapso do filme: os lipídeos da interface não suportam a compressão e passam a se acumular em cima do filme, formando multicamadas (FIGURA 20). Logo, a pressão de colapso dá uma ideia do grau de estabilidade do filme: quando maior o valor da pressão de colapso, mais estável (resistente à compressão) era o filme. Nota-se também que a altas pressões $(\pi \approx 50 \mathrm{mN} / \mathrm{m})$ as isotermas em água pura (\#3) e em tampão Tris (\#4,\#5) tornam-se praticamente idênticas, indicando que a essas altas pressões o efeito do tampão no empacotamento do filme é desprezível.

\subsubsection{Metodologia \#2: Dinâmica Isobárica (Diagrama $\sigma-t)$}

Como visto anteriormente, a Metodologia \#1 nos fornece um diagrama riquíssimo em informações a respeito da interação entre compostos dispersos na subfase (por exemplo, antimicrobianos) com os lipídeos da monocamada. Entretanto, o processo de compressão isotérmica é de fato um processo de formação de uma membrana lipídica. Portanto, quando há antimicrobianos na subfase, a interpretação mais adequada da Metodologia \#1 é: a medida do grau de afinidade/perturbação que os antimicrobianos na subfase ("em meio extracelular") tem/causam durante a formação da membrana modelo (lembre-se que as pressões relevantes biologicamente são em 
torno de $\pi=30 \mathrm{mN} / \mathrm{m}$ ). Eventualmente, durante uma divisão celular isso pode ser biologicamente relevante. Entretanto, temos interesse em saber se um composto antimicrobiano tem capacidade de penetrar uma membrana já formada. Por esta razão, temos que investigar as perturbações que antimicrobianos causam em uma Monocamada de Langmuir a uma dada pressão superficial constante representativa (Processos isobáricos a $\pi=30 \mathrm{mN} / \mathrm{m}$ ).

Ao contrário da Metodologia \#1, na Metodologia \#2 a subfase sempre é a água pura no início. As etapas neste método são as seguintes: espalhar o lipídeo sobre a água pura; esperar o clorofórmio evaporar (15 a 20min); comprimir isotermicamente o filme lipídico até a pressão de interesse (Target: $\pi=30 \mathrm{mN} / \mathrm{m}$ ). Nota: até agora é equivalente à metodologia \#1 com subfase controle (água pura). Em seguida, deve-se manter essa pressão de interesse por mecanismo de feedback (Hold: $\pi=30 \mathrm{mN} / \mathrm{m}$ ); esperar alguns minutos (5 a 10 minutos) para estabilizar nessa pressão; injetar na subfase (por detrás das barreiras e em direção ao filme já formado) cerca de $200 \mu \mathrm{L}$ de uma solução concentrada de antimicrobiano (de modo que o número de moléculas de antimicrobiano dentro da subfase seja igual a um experimento feito pela Metodologia \#1 cuja subfase é uma solução de antimicrobiano); acompanhar $\sigma(\mathrm{t})$ : a mudança de $\sigma$ em função do tempo (cerca de horas).

\subsubsection{Interpretação do Diagrama $\sigma-t$}

Aqui, se ocorre uma expansão isobárica quando o antimicrobiano é injetado na subfase, isto é, $\sigma(\mathrm{t})$ aumenta depois que injetamos o composto no volume, então ele é capaz de penetrar na monocamada de lipídeos em uma pressão superficial biologicamente relevante $\pi=30 \mathrm{mN} / \mathrm{m} .{ }^{102}$ Ao contrário, se $\sigma(\mathrm{t})$ diminui após a injeção do composto na subfase, ele é capaz de remover uma fração dos lipídeos que estavam na superfície e solubilizá-los na subfase. 


\subsection{FUNDAMENTOS DE ÓPTICA NÃO LINEAR}

\subsubsection{Fenômenos Ópticos Lineares e Não Lineares}

Quaisquer fenômenos ópticos decorrem da interação da luz com a matéria. Tal interação gera uma polarização oscilante $\vec{P}(\omega)$ no material que atua como uma nova fonte luminosa - cujo o feixe irradiado pelos dipolos oscilantes do material tem propriedades diferentes da radiação incidente. ${ }^{104-106}$ Isto é, o destino e as propriedades da radiação eletromagnética (EM) emitida por $\vec{P}(\omega)$ depende tanto das características da radiação incidente quanto do material, pois é a interação de ambos que gera $\vec{P}(\omega)$.

\subsubsection{Regime da Óptica Linear}

Em física da matéria condensada, a susceptibilidade elétrica $\chi$ de um material é a grandeza que relaciona o campo elétrico óptico aplicado ao meio, $\vec{E}_{\mathrm{i}}\left(\omega_{\mathrm{i}}\right)$, com a sua respectiva resposta do meio (polarização $\vec{P}(\omega)$ ). Quando $\left|\vec{E}_{i}\right|$ incidente é muito menor que o campo elétrico atômico característico $\left|\vec{E}_{a t}\right| \approx 5,14.10^{11} \mathrm{~V} / \mathrm{m}$, a polarização gerada no material responde linearmente ao campo (FIGURA 22). ${ }^{104}$

FIGURA 22 - RESPOSTAS LINEARES DO MEIO.
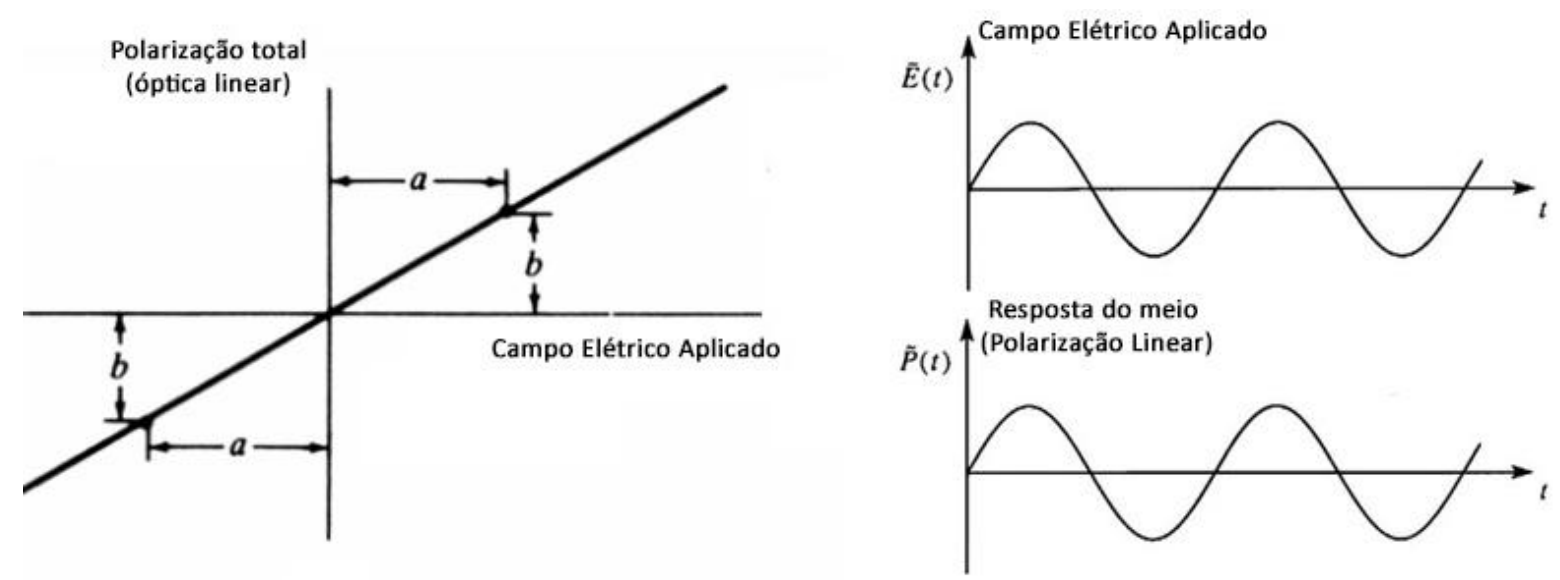

Fonte: Adaptada de BOYD ${ }^{104}$.

$$
\vec{P}(\omega)=\vec{P}\left(\omega_{i}\right)=\varepsilon_{0} \cdot \chi^{(1)} \cdot \vec{E}_{i}\left(\omega_{i}\right)
$$


em que $\varepsilon_{0}$ é a permissividade elétrica no vácuo e $\chi^{(1)}$ é a susceptibilidade elétrica linear (i.e., de primeira ordem) do material, responsável por fenômenos de óptica linear convencionais (absorção, refração e reflexão). Tipicamente, $\chi^{(1)} \approx 1$ (Sistema Internacional) para meios transparentes (não absorvedores). Ademais, no regime de óptica linear, o material é incapaz de alterar a cor (frequência) da radiaçãoiii. Consequentemente, $\omega_{\text {polarização }}=\omega_{\text {luz incidente }}$. Assim, se incidirmos vários feixes de cores diferentes neste material, ele não é capaz de gerar um feixe luminoso em uma frequência diferente daquela da luz incidente. Desta forma, todas as radiações emitidas por $\vec{P}(\omega)$, ou seja, todos os feixes transmitidos ou refletidos, tem mesma frequência que o campo incidente. Portanto, no regime de óptica linear, o $\chi^{(1)}$ não ressonante só é capaz de alterar a amplitude, a direção e a velocidade de propagação do feixe luminoso (i.e., vetor de onda).

\subsubsection{Regime da Óptica Não Linear}

Conforme se aumenta a amplitude do campo elétrico incidente, o material passa a responder de forma não linear (FIGURA 23).104

FIGURA 23 - RESPOSTAS NÃO LINEARES DO MEIO.
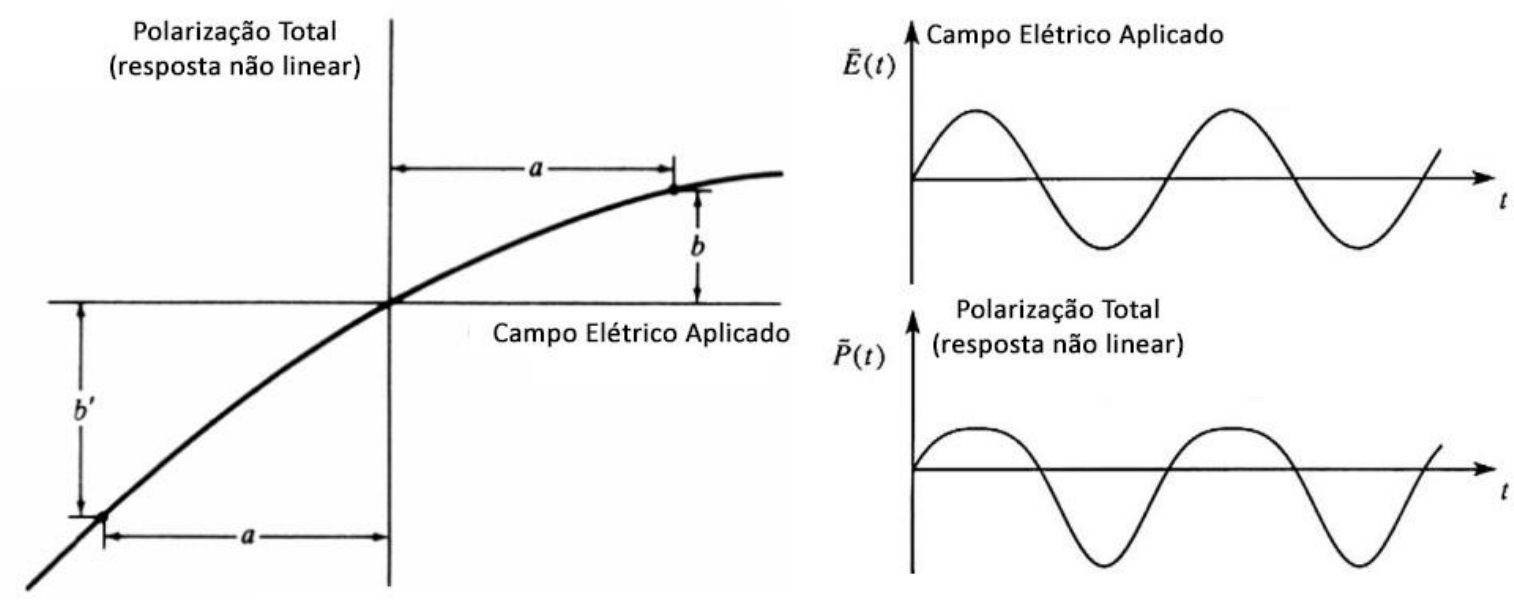

Fonte: Adaptada de BOYD. ${ }^{104}$

iii A mudança de cor por absorção é simplesmente resultado da atenuação seletiva de componentes espectrais 
Ou seja, a polarização do material não mais acompanha proporcionalmente as oscilações da luz incidente e, para ser descrita apropriadamente, é necessário expandir $\vec{P}(\omega)$ em série de potências. ${ }^{104-107}$

$$
\begin{gathered}
\vec{P}=\varepsilon_{0}\left[\overleftrightarrow{\chi}^{(1)} \cdot \vec{E}_{i}+\overleftrightarrow{\chi}^{(2)} \cdot \vec{E}_{i} \cdot \vec{E}_{j}+\overleftrightarrow{\chi}^{(3)} \cdot \vec{E}_{i} \cdot \vec{E}_{j} \cdot \vec{E}_{k}+\cdots\right] \\
\vec{P}=\vec{P}^{(1)}+\vec{P}^{(2)}+\vec{P}^{(3)}+\cdots
\end{gathered}
$$

em que $\vec{E}_{i}, \vec{E}_{j}, \vec{E}_{k}$ são os campos incidentes com frequências $\omega_{\mathrm{i}}$, $\omega_{\mathrm{j}}$ e $\omega_{\mathrm{k}}$ (não necessariamente idênticas) e $\vec{P}^{(n)}$ a polarização de n-ésima ordem com frequência $\omega_{\mathrm{n}}$, tal que $\mathrm{n} \in \mathbb{N}^{*}$. As grandezas $\chi^{(2)}$ e $\chi^{(3)}$ são respectivamente denominadas susceptibilidades elétricas não lineares de segunda e de terceira ordem. Tipicamente, em meios transparentes (não ressonantes), os valores de $\chi^{(2)}$ e $\chi^{(3)}$ são da ordem de $1 / \mathrm{E}_{\mathrm{at}} \mathrm{e}\left(1 / \mathrm{E}_{\mathrm{at}}\right)^{2}$ respectivamente. Ou seja, $\chi^{(2)} \approx 1,94.10^{-12} \mathrm{~m} / \mathrm{V}$ e $\chi^{(3)} \approx 3,78.10^{-24}$ $\mathrm{m}^{2} / \mathrm{V}^{2}$. Portanto, a amplitude do campo elétrico incidente deve ser de fato muito alta para podermos detectar a ocorrência de fenômenos não lineares. ${ }^{104}$ É por esta razão que foi só depois do desenvolvimento de laser pulsados, de altíssimas intensidades de pico, que o ramo de óptica não linear começou a se desenvolver. Para os nossos experimentos, estamos interessados na polarização não linear de segunda ordem, $\vec{P}^{(2)}$.

\subsection{Processos Ópticos Não Lineares de Segunda Ordem}

Como representamos os campos elétricos incidentes por exponenciais complexas, i.e., $\vec{E}_{j} \propto e^{i\left(\overrightarrow{k_{J}} \cdot \vec{r}+\omega_{j} \cdot t\right)}$, em que $\mathrm{j}=1,2,3, \ldots$, então, os termos de polarização não lineares, $\vec{P}^{N L} \equiv \vec{P}^{(n)}$, tal que $\mathrm{n}>1$, necessariamente envolvem a multiplicação dessas exponenciais. ${ }^{104-107}$ Desta forma, a polarização do material pode oscilar/irradiar em frequências diferentes das dos campos EM aplicados $\left(\vec{E}_{i}, \vec{E}_{j}, \vec{E}_{k}, \ldots\right)$, visto que ocorre a soma dos expoentes. Por exemplo, suponha que duas ondas EM idealmente planas de frequências $\omega_{1}$ e $\omega_{2}$ sejam aplicadas a um material. Essas ondas EM são descritas respectivamente pelos campos $\quad \vec{E}_{1}=\left[E_{1}(\vec{r}) e^{-i \omega_{1} t}+E_{1}^{*}(\vec{r}) e^{+i \omega_{1} t}\right] . \hat{e} \quad \mathrm{e}$ $\vec{E}_{2}=\left[E_{2}(\vec{r}) e^{-i \omega_{2} t}+E_{2}^{*}(\vec{r}) e^{+i \omega_{2} t}\right] \cdot \hat{e}$, em que $E_{1}(\vec{r})$ e $E_{2}(\vec{r})$ são as amplitudes complexas 
dos campos 1 e 2 na posição $\vec{r}$ e o asterisco (*) indica o respectivo complexo conjugado (c.c.). Logo, a magnitude do campo total aplicado pode ser sucintamente escrito como:

$$
\tilde{E}(t)=E_{1} e^{-i \omega_{1} t}+E_{2} e^{-i \omega_{2} t}+c . c .
$$

Considerando somente os fenômenos ópticos dependentes do termo de segunda ordem da Equação 13, a magnitude da resposta não linear do meio neste caso é descrita por:

$$
\tilde{P}^{(2)}(t)=\varepsilon_{0} \chi^{(2)} \tilde{E}^{2}(t)
$$

Então, todos os possíveis processos não lineares de segunda ordem (i.e., dependentes exclusivamente de $\vec{P}^{(2)}$ ) são descritos pelos seguintes termos:

$$
\begin{aligned}
\vec{P}^{(2)}=\varepsilon_{0} \chi^{(2)}\left[\begin{array}{c}
E_{1}^{2} \cdot e^{-2 i \omega_{1} t}+E_{2}^{2} \cdot e^{-2 i \omega_{2} t}+ \\
2 E_{1} E_{2} \cdot e^{-2 i\left(\omega_{1}+\omega_{2}\right) t}+2 E_{1} E_{2}^{*} \cdot e^{-2 i\left(\omega_{1}-\omega_{2}\right) t}+\text { c.c. }
\end{array}\right] & \\
& +2 \varepsilon_{0} \chi^{(2)}\left[E_{1} E_{1}^{*}+E_{2} E_{2}^{*}\right]
\end{aligned}
$$

Uma vez que cada termo do lado direito da Equação 16 causa uma oscilação típica de $\vec{P}^{(2)}$ distinta das outras, cada um destes termos é responsável por fenômeno óptico não linear de segunda ordem diferente (TABELA 06). 0 que determina qual termo vai dominar os outros é $\chi^{(2)}$ e a conservação do momento dos fótons de entrada e saída do meio material, conhecida como condição de casamento de fase. ${ }^{104}$

TABELA 06 - FENÔMENOS NÃO LINEARES DE SEGUNDA ORDEM. Os termos que são complexos conjugados destes descrevem os mesmo fenômenos. O que muda é somente a fase da onda gerada. Em negrito, destacamos o processo óptico não linear de Geração por Soma de Frequências, que é a fenômeno físico por trás da técnica da Espectroscopia Vibracional Não Linear que usaremos para a caracterização molecular dos Filmes de Langmuir (Modelos de Membrana).

\begin{tabular}{|c|c|}
\hline Termo & Nome do fenômeno óptico \\
\hline$P\left(2 \omega_{1}\right)=\varepsilon_{0} \chi^{(2)} E_{1}^{2} \cdot e^{-2 i \omega_{1} t}$ & $\begin{array}{c}\text { Geração de Segundo Harmônico do feixe 1 } \\
\text { (Second Harmonic Generation, SHG) }\end{array}$ \\
\hline$P\left(2 \omega_{2}\right)=\varepsilon_{0} \chi^{(2)} E_{2}^{2} \cdot e^{-2 i \omega_{2} t}$ & $\begin{array}{c}\text { Geração de Segundo Harmônico do feixe 2 } \\
\text { (Second Harmonic Generation, SHG) }\end{array}$ \\
\hline$P\left(\boldsymbol{\omega}_{\mathbf{1}}+\boldsymbol{\omega}_{2}\right)=2 \varepsilon_{\mathbf{0}} \chi^{(2)} \boldsymbol{E}_{\mathbf{1}} \boldsymbol{E}_{2} \cdot \boldsymbol{e}^{-\boldsymbol{i}\left(\boldsymbol{\omega}_{1}+\boldsymbol{\omega}_{2}\right) \boldsymbol{t}}$ & $\begin{array}{c}\text { Geração de Soma de Frequências } \\
\text { (Sum-Frequency Generation, SFG) }\end{array}$ \\
\hline$P\left(\omega_{1}-\omega_{2}\right)=2 \varepsilon_{0} \chi^{(2)} E_{1} E_{2}^{*} \cdot e^{-i\left(\omega_{1}-\omega_{2}\right) t}$ & $\begin{array}{c}\text { Geração de Diferença de Frequências } \\
\text { (Difference-Frequency Generation, DFG) }\end{array}$ \\
\hline$P(0)=2 \varepsilon_{0} \chi^{(2)}\left[E_{1} E_{1}^{*}+E_{2} E_{2}^{*}\right]$ & $\begin{array}{c}\text { Retificação Óptica } \\
\text { (Optical Rectification, OR) }\end{array}$ \\
\hline
\end{tabular}

Fonte: Adaptada de BOYD ${ }^{104}$. 


\subsection{Natureza Tensorial de $\overleftrightarrow{\chi}^{(2)}$}

Os termos descritos na TABELA 06 não estão considerando a natureza vetorial dos campos elétricos incidentes, nem da polarização não linear produzida pelo meio. Logo, diferentes polarizações dos feixes incidentes podem gerar diversas respostas de $\vec{P}^{(2)}$. Como $\chi^{(2)}$ é a grandeza que relaciona a combinação de campos vetoriais de entrada (radiações incidentes $\vec{E}_{1}$ e $\vec{E}_{2}$ ) com o campo EM emitido pelo material (radiação de $\vec{P}^{(2)}$ ), então $\chi^{(2)}$ tem de ser descrito matematicamente por um tensor de posto 3 (i.e., com 3 índices, $\overleftrightarrow{\chi}_{i, j, k}^{(2)}$, constituído de 27 elementos em um espaço tridimensional).104-106 Cada índice está relacionado a uma dessas grandezas vetoriais $\left(i \leftrightarrow \vec{P}^{(2)}\right.$ como resposta; $j \leftrightarrow \vec{E}_{1}$ como entrada $1 ; k \leftrightarrow \vec{E}_{2}$ como entrada 2 ). Ou seja, a componente i (i=x, y ou z) de $\vec{P}^{(2)}$ pode ser descrita como:

$$
P_{i}^{(2)}=\varepsilon_{0} \sum_{j, k} \chi_{i, j, k}^{(2)} E_{j} E_{k}
$$

Isto é, se abríssemos todos os elementos da Equação 17 teríamos:

$$
\left(\begin{array}{c}
P_{x}^{(2)} \\
P_{y}^{(2)} \\
P_{z}^{(2)}
\end{array}\right)=\left(\begin{array}{lllllllll}
\chi_{x x x}^{(2)} & \chi_{x x y}^{(2)} & \chi_{x x z}^{(2)} & \chi_{x y x}^{(2)} & \chi_{x y y}^{(2)} & \chi_{x y z}^{(2)} & \chi_{x z x}^{(2)} & \chi_{x z y}^{(2)} & \chi_{x z z}^{(2)} \\
\chi_{y x x}^{(2)} & \chi_{y x y}^{(2)} & \chi_{y x z}^{(2)} & \chi_{y y x}^{(2)} & \chi_{y y y}^{(2)} & \chi_{y y z}^{(2)} & \chi_{y z x}^{(2)} & \chi_{y z y}^{(2)} & \chi_{y z z}^{(2)} \\
\chi_{z x x}^{(2)} & \chi_{z x y}^{(2)} & \chi_{z x z}^{(2)} & \chi_{z y x}^{(2)} & \chi_{z y y}^{(2)} & \chi_{z y z}^{(2)} & \chi_{z y x}^{(2)} & \chi_{z z y}^{(2)} & \chi_{z z z}^{(2)}
\end{array}\right):\left(\begin{array}{l}
E_{1 x} E_{2 x} \\
E_{1 x} E_{2 y} \\
E_{1 x} E_{2 z} \\
E_{1 y} E_{2 x} \\
E_{1 y} E_{2 y} \\
E_{1 y} E_{2 z} \\
E_{1 z} E_{2 x} \\
E_{1 z} E_{2 y} \\
E_{1 z} E_{2 z}
\end{array}\right)
$$

\subsection{O Papel da Simetria na Natureza Tensorial de $\overleftrightarrow{\chi}^{(2)}$}

Todos os fenômenos ópticos não lineares de $2^{\underline{a}}$ ordem dependem da susceptibilidade não linear $\overleftrightarrow{\chi}_{i, j, k}^{(2)} \cdot 106$ Tais processos (incluindo o de SFG, que nos interessa) são mais prováveis de acontecer (i.e., geram mais sinal) quanto maiores forem os valores dos elementos deste tensor. Em outras palavras, eventuais elementos nulos não resultam em fenômenos ópticos não lineares. Além disso, os elementos de $\overleftrightarrow{\chi}_{i, j, k}^{(2)}$ dependem exclusivamente do material - sobretudo de sua simetria. Dependendo do 
quão simétrico for o material, alguns elementos podem ser idênticos - o que facilita a sua caracterização. Mais do que isso, os elementos tensores de posto 3 tem intrinsecamente a seguinte propriedade: 106

$$
\chi_{-i,-j,-k}^{(2)}=-\chi_{i, j, k}^{(2)}
$$

Em outras palavras, se mudarmos o sentido dos eixos que descrevem o material, os elementos desse tensor mudam de sinal (pois cada índice do tensor $\chi_{i, j, k}^{(2)}$ se transforma por rotações como um vetor, e invertendo os eixos do sistema de coordenadas, as componentes de um vetor trocam de sinal). Entretanto, em meios com simetria de inversão, não se observa mudança no material quando se muda o sentido dos eixos que descrevem o sistema (como tentar encontrar alguma diferença de estrutura de uma esfera ao deixá-la de ponta-cabeça). Assim, tais meios centrossimétricos seriam matematicamente descritos por:

$$
\chi_{-i,-j,-k}^{(2)}=+\chi_{i, j, k}^{(2)}
$$

Logo, de imediato, percebemos que a propriedade tensorial que descreve os fenômenos ópticos não lineares de segunda ordem (na realidade, todos de ordem par) (Equação 18) é incompatível com a descrição de meios centrossimétricos (Equação 19).106,107 Portanto, os elementos da susceptibilidade não linear de $2^{\mathrm{a}}$ ordem $\chi_{i, j, k}^{(2)}$ são nulos em meios com simetria de inversão e, consequentemente, não geram sinal SFG. Por outro lado, meios sem simetria de inversão (como interfaces líquido-ar) podem ser descritos por elementos de $\chi_{i, j, k}^{(2)}$ que são não nulos e , consequentemente, podem gerar sinal SFG (ou quaisquer outros fenômenos descritos na TABELA 06, pois também seguem essa lógica). Em suma:

TABELA 07 - RESUMO DE ALGUMAS PROPRIEDADES DE SIMETRIA DE $\overleftrightarrow{\chi}^{(2)}$

\begin{tabular}{|c|c|c|c|}
\hline Tipo de Meio & Exemplos & Elementos de $\overleftrightarrow{\chi}^{(2)}$ & Sinal SFG, SHG, DFG, etc \\
\hline $\begin{array}{c}\text { Sem simetria de inversão } \\
\text { (Orientação Preferencial) }\end{array}$ & $\begin{array}{c}\text { Interfaces, alguns materiais } \\
\text { anisotrópicos/quirais... }\end{array}$ & $\chi_{i, j, k}^{(2)} \neq 0$ & Talvez \\
\hline $\begin{array}{c}\text { Com simetria de inversão } \\
\text { (Centrossimétricos) }\end{array}$ & $\begin{array}{c}\text { Bulk de materiais amorfos ou } \\
\text { de fluidos,... }\end{array}$ & $\chi_{i, j, k}^{(2)}=0$ & Não \\
\hline
\end{tabular}

Fonte: Adaptada de SHEN ${ }^{69}$. 


\subsection{Interfaces Isotrópicas (com simetria $\mathrm{C}_{\infty}$ )}

Uma interface (por exemplo, plano-xy) entre dois meios homogêneos não quirais e isotrópicos (por exemplo: água-ar) tem simetria de rotação ao redor do eixo-z (grupo pontual $\left.\mathrm{C}_{\infty}\right)^{69-74,107}$ Neste tipo de simetria, as direções $\hat{x}$ e $\hat{y}$ são equivalentes e há simetria especular em relação aos planos xz e yz. Isto é, as posições na interface $x=-x$, $y=-y$ e $x= \pm y= \pm r_{0}$ são todas equivalentes para o meio material. Entretanto, ao longo do eixo-z há uma quebra de simetria, i.e., $z \neq-z$. Então, considerando esta simetria $\left(\mathrm{C}_{\infty}\right)$ e as restrições impostas pela Equação 18, apenas um número limitado de combinações vetoriais dos feixes EM incidentes $\left(\vec{E}_{1}, \vec{E}_{2}\right)$ e de saída $\left(\vec{P}^{(2)}\right)$ são mediados por elementos não nulos do tensor. Por exemplo, usando a simetria de inversão ao longo de x e a propriedade de transformação dos tensores de posto 3 (Equação 18), obtém-se $\chi_{x, x, x}^{(2)}=-\chi_{-x,-x,-x}^{(2)}=+\chi_{-x,-x,-x}^{(2)}=0$. Portanto, como os elementos do tensor $\overleftrightarrow{\chi}_{i, j, k}^{(2)}$ devem ser não nulos para gerar sinal SFG (ou qualquer outro processo decorrente de $\vec{P}^{(2)}$ ), estes elementos devem satisfazer a seguinte regra: ter um número par de índices na direção $\hat{x}$ ou $\hat{y}$ e um número ímpar de índices na direção $\hat{z}$. A tabela 08 resume alguns componentes que eventualmente podem gerar sinal SFG.(107)

TABELA $08-\chi_{i, j, k}^{(2)}$ geradores de SFG em interfaces com simetria C $\infty$

\begin{tabular}{|c|c|c|c|}
\hline$\chi_{z, x, x}^{(2)} \equiv \chi_{z, y, y}^{(2)}$ & $\chi_{x, z, x}^{(2)} \equiv \chi_{y, z, y}^{(2)}$ & $\chi_{x, x, z}^{(2)} \equiv \chi_{y, y, z}^{(2)}$ & $\chi_{z, z, z}^{(2)}$ \\
\hline
\end{tabular} Fonte: SILVA ${ }^{107}$.

Do ponto de vista experimental, podemos distinguir qual é o eixo-x e qual é o eixo-y ao fixarmos um sistema de referências ortogonal de laboratório (FIGURA 24). Logo, podemos definir a interface entre os dois meios como sendo o plano-xy (que continua sendo isotrópica do ponto de vista do material). Contudo, o feixe de laser pode estar linearmente polarizado em uma ou outra direção - i.e., paralela ao plano de incidência (Polarização-P) ou perpendicular ao plano de incidência (Polarização-S).107 Desta forma, se experimentalmente estabelecermos o plano-xz como coplanar ao plano de incidência de ambos os feixes $\vec{E}_{1}$ e $\vec{E}_{2}$ (para facilitar), consequentemente a Polarização-P reside no plano-xz e a Polarização-S é paralela ao eixo-y. Assim, os elementos de $\overleftrightarrow{\chi}_{i, j, k}^{(2)}$ que podem contribuir para gerar o processo de soma de frequências, 
em termos das polarizações (S ou P) dos feixes laser incidentes, estão listados na TABELA 09.

FIGURA 24 - REFERENCIAL DE LABORATÓRIO E COMBINAÇÕES DAS POLARIZAÇÕES DOS CAMPOS ÓPTICOS. Feixes gerados por soma de frequências (SFG, em azul). Feixe incidente no visível (VIS, em verde). Feixe incidente infravermelho (IR, em vermelho). Cada um desses feixes ópticos pode estar com Polarização-s $\left(\vec{E}_{S}\right)$, que é perpendicular ao plano de incidência (paralela ao eixo-y), ou com a Polarização-p $\left(\vec{E}_{P}\right)$, que é paralela ao plano de incidência (plano-xz). Então, medidas feitas em cada combinação (i', j', $k^{\prime}$ ) de polarizações (s ou p) desses 3 feixes proporcionam resultados (espectros) diferentes. Isto é, cada combinação de polarizações (i' =polarização $s$ ou $p$ do SFG; j' =polarização $s$ ou $p$ do VIS; $\mathbf{k}^{\prime}$ =polarização $s$ ou $p$ do IR) está associado um elemento do tensor de $\overleftrightarrow{\chi}_{i, j, k}^{(2)}$, que gera um espectro diferente. Legenda: $\varepsilon_{1}$ e $\varepsilon_{2}$ são as permissividades elétricas do meio 1 e do meio 2 respectivamente; $\chi_{v}{ }^{(2)}$ e $\chi_{s s}{ }^{(2)}$ são as susceptibilidades elétricas não lineares de $2^{\mathrm{a}}$ ordem do bulk do meio 2 e da interface isotrópica entre os meios respectivamente. Note que só as moléculas interfaciais são responsáveis pela geração de soma de frequências.

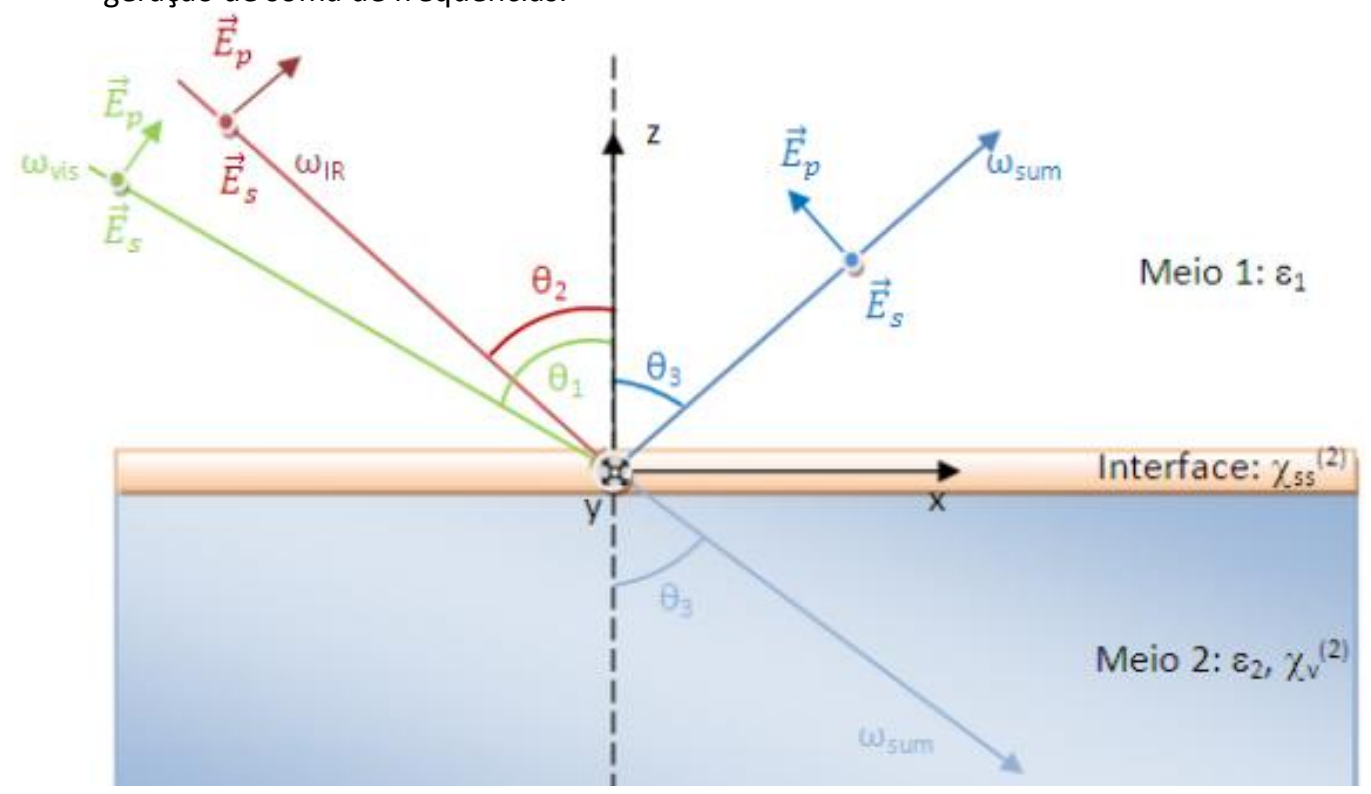

Fonte: SILVA. 107

TABELA 09 - POLARIZAÇÕES DOS CAMPOS (SFG, VIS, IR) E OS ELEMENTOS $\chi_{i, j, k}^{(2)}$. Considerando o referencial de laboratório (FIGURA 24), temos: Polarização-s (ao longo do eixo-y); Polarização-p (no plano-xz). Se também considerarmos interface (plano-xy) isotrópica, as possíveis $\left(i^{\prime}, j^{\prime}, k^{\prime}\right)$ combinações de polarizações ( $s$ ou $p$ ) dos feixes ( $i^{\prime} \rightarrow S F G, k^{\prime} \rightarrow V I S, k^{\prime} \rightarrow I R$ ) capazes de contribuir para $p$ processo de geração de soma de frequências (se $\chi_{i, j, k}^{(2)}$ não nulos, cf.TABELA 08) são:

\begin{tabular}{|c|c|}
\hline Combinação de polarização (i' $\left.\rightarrow \mathrm{SFG}, \mathrm{k}^{\prime} \rightarrow \mathrm{VIS}, \mathrm{k}^{\prime} \rightarrow \mathrm{IR}\right)$ & Respectivo elemento de $\chi_{i, j, k}^{(2)}$ \\
\hline $\mathrm{ssp}$ & $\chi_{y, y, z}^{(2)}$ \\
\hline $\mathrm{sps}$ & $\chi_{y, z, y}^{(2)}$ \\
\hline $\mathrm{pss}$ & $\chi_{z, y, y}^{(2)}$ \\
\hline $\mathrm{ppp}$ & $\chi_{z, z, z}^{(2)} ; \chi_{z, x, x}^{(2)} ; \chi_{x, z, x}^{(2)} ; \chi_{x, x, z}^{(2)}$ \\
\hline
\end{tabular}

Fonte: SILVA. ${ }^{107}$ 


\subsection{ESPECTROSCOPIAS NÃO LINEARES DE SEGUNDA ORDEM}

Até agora comentamos sobre a natureza de processos ópticos não lineares em situações distantes de processos ressonantes, isto é, quando as frequências dos campos incidentes $\left(\omega_{q} \mathrm{e} \omega_{2}\right)$ são muito diferentes das frequências ressonantes do material $\left(\omega_{q}\right)$ :

$$
\chi^{(2)} \approx \chi_{N R}^{(2)}
$$

em que $\chi_{N R}^{(2)}$ descreve cada elemento de $\overleftrightarrow{\chi}_{i, j, k}^{(2)}$ na situação Não Ressonante.

Entretanto, quando se varia a frequência de um desses feixes incidentes (por exemplo, $\left.\vec{E}_{2}\right)$ fazendo com que $\omega_{2}$ se aproxime de $\omega_{q}\left(\omega_{2} \rightarrow \omega_{q}\right)$, os elementos do tensor de $\overleftrightarrow{\chi}_{i, j, k}^{(2)}$ mudam de valor, aumentando a probabilidade de se gerar um fenômeno óptico não linear (por exemplo, fótons de SFG) ${ }^{104,106-107}$. Nestas condições (Ressonantes), $\chi^{(2)}$ tem de ser escrito como:

$$
\chi^{(2)}=\chi_{R}^{(2)}+\chi_{N R}^{(2)}
$$

em que $\chi_{R}^{(2)}$ é a susceptibilidade não linear de $2^{\mathrm{a}}$ ordem na condição em que $\omega_{2}$ está nas vizinhanças de $\omega_{q}$. Logo, o termo $\chi_{R}^{(2)}$ pode ser escrito como:

$$
\chi_{R}^{(2)}=\sum_{q} \frac{A_{q}}{\omega_{2}-\omega_{q}+i \Gamma_{\mathrm{q}}}
$$

em que $A_{q}$ é amplitude de vibração do modo $q$ e $\Gamma_{\mathrm{q}}$ é a largura do pico.

Destarte, a Equação 21 pode ser reescrita como:

$$
\chi^{(2)}=\chi_{N R}^{(2)}+\sum_{q} \frac{A_{q}}{\omega_{2}-\omega_{q}+i \Gamma_{\mathrm{q}}}
$$

Note que $\chi^{(2)}$ fornece o Espectro SFG. ${ }^{68-74,107}$ 
Tal aumento ressonante pode ser entendido qualitativamente da seguinte maneira. Podemos interpretar que a frequência de oscilação $\boldsymbol{\omega}_{S F G}$ de $\vec{P}^{(2)}\left(\boldsymbol{\omega}_{\boldsymbol{S F G}}\right)$ como o resultado da interação não linear entre as duas frequências incidentes $\left(\boldsymbol{\omega}_{1} e \boldsymbol{\omega}_{2}\right)$, mediada pela resposta não linear do material. Como as duas polarizações lineares geradas $\vec{P}_{1}^{(1)}\left(\boldsymbol{\omega}_{1}\right)$ e $\vec{P}_{2}^{(1)}\left(\boldsymbol{\omega}_{2}\right)$ oscilam de forma coerente no material, é como se a pequena resposta não linear de $\vec{P}^{(2)}$ representasse a interação entre essas duas. Note que:

$$
\vec{P}^{(2)}\left(\boldsymbol{\omega}_{S F G}\right) \propto \overleftrightarrow{\chi}^{(2)}: \vec{E}_{1}\left(\boldsymbol{\omega}_{1}\right) \vec{E}_{2}\left(\boldsymbol{\omega}_{2}\right)
$$

Que, em termos das polarizações lineares (primeira ordem):

$$
\vec{P}^{(2)}\left(\omega_{S F G}=\omega_{1}+\omega_{2}\right) \propto \overleftrightarrow{\chi}^{(2)}: \vec{P}_{1}^{(1)}\left(\omega_{1}\right) \vec{P}_{2}^{(1)}\left(\omega_{2}\right)
$$

A onda de emitida resultante desta interação, quando analisada no Espaço de Fourier, contém novas componentes espectrais: a soma e a diferença das frequências. Assim, quando $\omega_{2}$ se aproxima dos valores ressonantes do material $\left(\omega_{2} \rightarrow \omega_{q}\right)$, a magnitude da oscilação de $\vec{P}_{2}^{(1)}\left(\boldsymbol{\omega}_{2}\right)$ aumenta drasticamente por causa da ressonância. Consequentemente, a amplitude da interação será maior, proporcionando um valor maior de $\vec{P}^{(2)}\left(\boldsymbol{\omega}_{\boldsymbol{S F G}}\right)$. Nota: a frequência gerada de maior relevância depende da fase relativa entre a polarização não linear $\vec{P}^{(2)}$ e as ondas incidentes. Isto é, para a ocorrência de cada fenômeno não linear de $2^{\text {a }}$ ordem (SHG, SFG, DFG, OR), há um par de frequências incidentes específico e uma condição de casamento de fase típica. Portanto, o experimentador pode escolher que fenômeno óptico não linear ele deseja usufruir controlando as frequências incidentes e a condição de casamento de fase apropriada (conservação do momento linear dos fótons incidentes e gerados).104-107

\subsubsection{A Espectroscopia Vibracional Não Linear por SFG}

Considere que $\omega_{2}=\omega_{I R}$, tal que $\omega_{I R}$ é uma frequência sintonizável (ajustável) na região do infravermelho médio $\left(2 \mu \mathrm{m}<\lambda_{\mathrm{IR}}<20 \mu \mathrm{m}\right)$. Considere também $\omega_{1}=\omega_{v i s}$, em que $\omega_{\text {vis }}$ é uma frequência não ressonante e constante no espectro visível (por exemplo, $\left.\lambda_{\text {verde }}=532 \mathrm{~nm}\right)$. Então, conforme percorremos os diferentes valores de $\omega_{I R}$, este 
eventualmente se aproximará das frequências naturais de vibração do material $\left(\omega_{I R} \rightarrow\right.$ $\omega_{q}$ ). Consequentemente, devido a um aumento do número de fótons-SFG gerado pela polarização não linear de $2^{\text {a }}$ ordem $\vec{P}^{(2)}$ nas condições ressonantes, podemos detectar o espectro vibracional pela geração de soma de frequências. ${ }^{69-74,108}$ Picos de sinal SFG ocorrerão quando $\omega_{I R} \rightarrow \omega_{q}$ :

$$
\omega_{S F G}^{\text {Espectro" }}=\omega_{\text {vis }}^{\text {Fixo }}+\omega_{I R}^{\text {Sintonizável" }}
$$

Em outras palavras, detectamos o espectro vibracional (na região do infravermelho médio, IR) da amostra na região do espectro visível, pois o fenômeno de soma das frequências (SFG) translada todos os valores de frequências do espectro por um valor fixo ( $\left.\omega_{v i s}\right)$ (FIGURA 25$)$.

FIGURA 25 - A ESPECTROSCOPIA SFG. (a) Pulsos de laser em relação à amostra. (b) Diagrama de energias: conforme o feixe no IR se aproxima das ressonâncias vibracionais do material, há um aumento na probabilidade de geração de soma de frequências. Assim, os picos no espectro SFG estão relacionados às frequências de ressonâncias vibracionais da amostra, dada pela Equação 26.

(a)

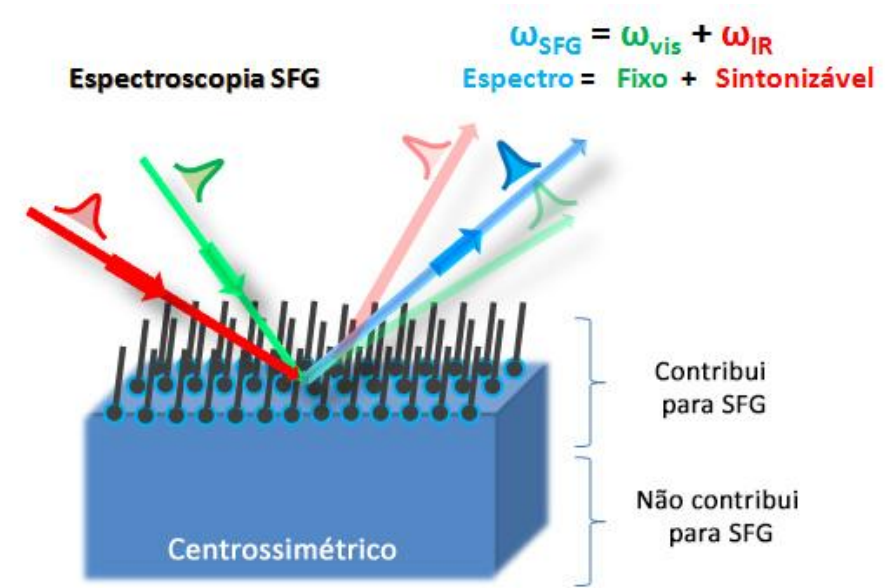

(b)

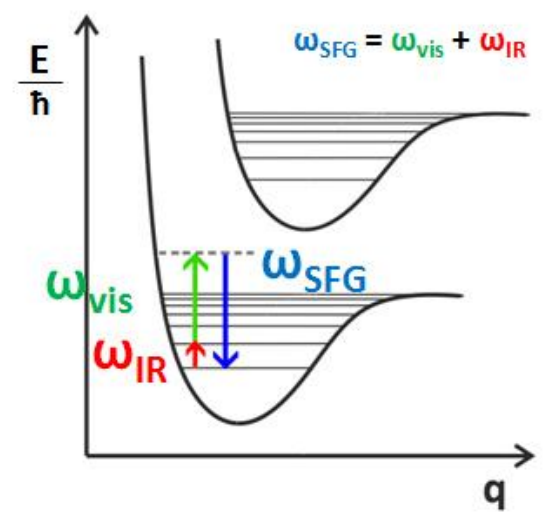

Fonte: Elaborada pelo autor.

A grande vantagem de se usar a Espectroscopia SFG é que ela é dependente de $\overleftrightarrow{\chi}_{i, j, k^{\prime}}^{(2)}$, um tensor de posto 3 que tem elementos nulos em meios centrossimétricos. ${ }^{69,104-}$ 
108 Logo, somente meios com quebra de simetria de inversão (por exemplo: interfaces) são capazes de gerar o fenômeno não linear de SFG. Consequentemente, nenhum espectro vibracional SFG é gerado pelas moléculas do interior tridimensional do material (bulk). Por esta razão, diz-se que a Espectroscopia Vibracional Não Linear por Geração de Soma de Frequências (Espectroscopia SFG) é uma técnica de caracterização óptica intrínseca de interfaces. Somente moléculas interfaciais (sem simetria de inversão) com uma orientação molecular preferencial bem determinada (em média "para cima" ou "para baixo") geram sinal SFG.

Na Espectroscopia SFG, somente os modos vibracionais que são simultaneamente ativos em Raman e em IR podem ser detectados.69,106-108 Isto é, a amplitude do $q$-ésimo modo vibracional, $A q$ (Equação 23), é proporcional a $P_{\alpha \beta}$ e $Q_{\gamma}$, os momentos de transição Raman e infravermelho:

$$
\chi_{R}^{(2)} \propto A_{q} \propto\left(P_{\alpha \beta} \cdot Q_{\gamma}\right)_{q} \propto\left\langle\beta_{\alpha \beta \gamma}\right\rangle
$$

Esta característica é uma consequência de ter moléculas sem simetria de inversão. Tal fato pode ser demonstrado usando a teoria da perturbação dependente do tempo até a $2^{\text {a }}$ ordem. ${ }^{108}$ Sucintamente falando, $\chi_{R}^{(2)}$ é a medida macroscópica de $\beta_{\alpha \beta \gamma}$ do material, a polarizabilidade não linear de $2^{\text {a }}$ ordem da molécula. Esta, por sua vez, descreve o processo de geração de soma de frequências do ponto de vista molecular e está associada à transição quântica de $2^{\mathrm{a}}$ ordem da teoria de perturbação dependente do tempo.107-108

\subsubsection{A Fase de $\overleftrightarrow{\chi}_{i, j, k}^{(2)}$}

Note que a intensidade $I\left(\omega_{S F G}\right)$ do feixe SFG emitido, além de ser proporcional às intensidades dos feixes incidentes $I\left(\omega_{S F G}\right) \propto I\left(\omega_{\text {vis }}\right) . I\left(\omega_{I R}\right)$, é também proporcional ao módulo quadrado da susceptibilidade elétrica de segunda ordem para aquela configuração de polarizações, $I\left(\omega_{S F G}\right) \propto\left|\chi^{(2)}\right|^{2}$, isto é:

$$
I\left(\omega_{S F G}\right) \propto\left|\chi^{(2)}\right|^{2} I_{v i s}\left(\omega_{v i s}\right) . I_{I R}\left(\omega_{I R}\right)
$$


Visto que:

$$
\left|\vec{P}_{i}^{(2)}\left(\omega_{S F G}\right)\right|^{2} \propto\left|\overleftrightarrow{\chi}_{i, j, k}^{(2)}: \vec{E}_{j ; v i s}\left(\omega_{v i s}\right) \vec{E}_{k ; I R}\left(\omega_{I R}\right)\right|^{2}
$$

Onde, pela Equação 23:

$$
\chi^{(2)}=\chi_{N R}^{(2)}+\sum_{q} \frac{A_{q}}{\omega_{2}-\omega_{q}+i \Gamma_{\mathrm{q}}}
$$

Isso leva a uma propriedade que é muito distinta das técnicas espectroscópicas (lineares) convencionais, pois o sinal medido $I\left(\omega_{S F G}\right)$ apresenta a interferência das ressonâncias dos diversos modos vibracionais e da contribuição não ressonante. Em outras palavras, ocorre uma soma dos campos irradiados na frequência $\omega_{S F G}$ antes de elevar ao quadrado. Assim, o sinal SFG incorpora a informação da fase relativa entre as diversas ressonâncias $A_{q}$ e também em relação a $\chi_{N R}^{(2)}$. Ou seja, dois picos ressonantes próximos podem ter tanto interferência construtiva, se coalescendo em um só, quanto destrutiva, criando um vale entre eles, dependendo do sinal relativo das amplitudes $A_{q}$ para os dois modos vibracionais. Tais interferências dependem da fase com que os grupos funcionais do material oscilam e mudam drasticamente a forma de linha do espectro. Para uma discussão mais detalhada, $c f$. literatura. ${ }^{107}$ Embora seja parâmetro que complica a interpretação dos Espectros SFG, a fase de uma ressonância pode ser útil. Por exemplo, se o experimentador tem um espectro com dois picos vizinhos relacionados a dois grupos funcionais distintos, ele pode acompanhar as mudanças nas formas de linhas espectrais conforme se altera as condições experimentais $(\mathrm{pH}$, temperatura, etc). Assim, se antes os dois picos interferiam construtivamente (oscilavam em fase) na situação 1 e, eventualmente, passam interferir destrutivamente (anti-fase) na situação 2, é um indício de que houve uma inversão no sentido da orientação molecular de um grupo funcional em relação ao outro. 


\subsubsection{A Combinação de Polarizações (s,s,p) dos feixes (SFG, VIS, IR)}

Diferentes combinações de polarizações (Polarização-S e Polarização-P) dos feixes (SFG, VIS e IR) nos proporcionam diferentes Espectros SFG, pois elas vão ser sensíveis a diferentes componentes (i', j', k') dos campos incidentes, cf. (TABELA 09). Em particular, a condição experimental de polarizações (s, s, p) dos respectivos feixes é muito interessante, pois equivale a investigar o elemento de tensor $\chi_{y, y, z}^{(2)}, c f$. (TABELA 09). Logo, nesta tríade, somente o componente $E_{z}\left(\omega_{I R}\right)$ contribui para $I\left(\omega_{S F G}\right)$. Consequentemente, o Espectro SFG nas polarizações SSP fornece uma interpretação direta das vibrações das moléculas da interface com momento de dipolo $\mu_{z}^{\prime}$ ao longo do eixo-z.

$$
\chi_{s, s, p}^{(2)}=\chi_{y, y, z}^{(2)} \propto A_{q} \propto\left(P_{y y} \cdot Q_{z}\right)_{q} \propto\left(P_{y y} \cdot\left\langle e\left|\mu_{z}^{\prime}\right| g\right\rangle\right)_{q}
$$

\subsection{Parâmetro (R) - Medindo Conformações Lipídicas}

Usando a tríade de Polarizações SSP, podemos medir em Filmes de Langmuir um parâmetro importante que fornece informação a respeito do grau do empacotamento molecular dos lipídeos na interface (FIGURA 26). Em particular, estamos interessados na região espectral das vibrações de grupos $\mathrm{C}-\mathrm{H}$, que tipicamente fica na região do infravermelho médio entre $2800 \mathrm{~cm}^{-1}<\tilde{v}<3000 \mathrm{~cm}^{-1}$, 
FIGURA 26 - PARÂMETRO R NOS ESPECTROS DE SFG DE COMBINAÇÃO (s. s. p). Aqui nós relacionamos o grau de empacotamento lipídico com as conformações all-trans e gauche medidas por Espectroscopia $\mathrm{SFG}^{(71)}$. Na combinação $(s, s, p)$, o espectro SFG está relacionado ao momento de dipolo resultante das vibrações ao longo do eixo-z. Assim, lipídeos na conformação all-trans tem grupos metileno $\mathrm{CH}_{2(s)}$ que não geram Sinal SFG. Em contrapartida, os grupos $\mathrm{CH}_{3(s)}$ geram muito sinal por permanecerem em uma orientação preferencial na interface, quebrando a simetria do sistema. Já com os lipídeos na conformação gauche ocorre o contrário: os grupos $\mathrm{CH}_{2(\mathrm{~s})}$ estão na conformação cis, que tem momento de dipolo vibracional do eixo-z e geram muito sinal SFG, enquanto as metilas, $\mathrm{CH}_{3(\mathrm{~s})}$, ficam livres para ter diferentes orientações, assemelhando-se a um bulk. Portanto, podemos definir o parâmetro $\mathbf{R}$, que é a razão entre os dois picos: $\mathbf{R} \equiv[$ (amplitude de $\left.\mathrm{CH}_{3(\mathrm{~s})}\right) /$ (amplitude de $\left.\mathrm{CH}_{2(\mathrm{~s})}\right)$ ]. Assim, se $\mathbf{R}>\mathbf{1}$, os lipídeos estão muito empacotados (a) e estão na conformação all-trans (A). Senão, $\mathbf{R}<\mathbf{1}$ e os lipídeos estão pouco empacotados (c) para acessar conformações gauche (C). Observações: $\mathrm{CH}_{3(\mathrm{FR})}$ é o pico de Ressonância de Fermi da metila, que é um modo vibracional que acopla uma torção ao estiramento simétrico. Esta figura ilustra o Espectro SFG um ácido graxo (1 cauda hidrofóbica). Nos nossos experimentos, utilizaremos fosfolipídeos ( 2 caudas hidrofóbicas).

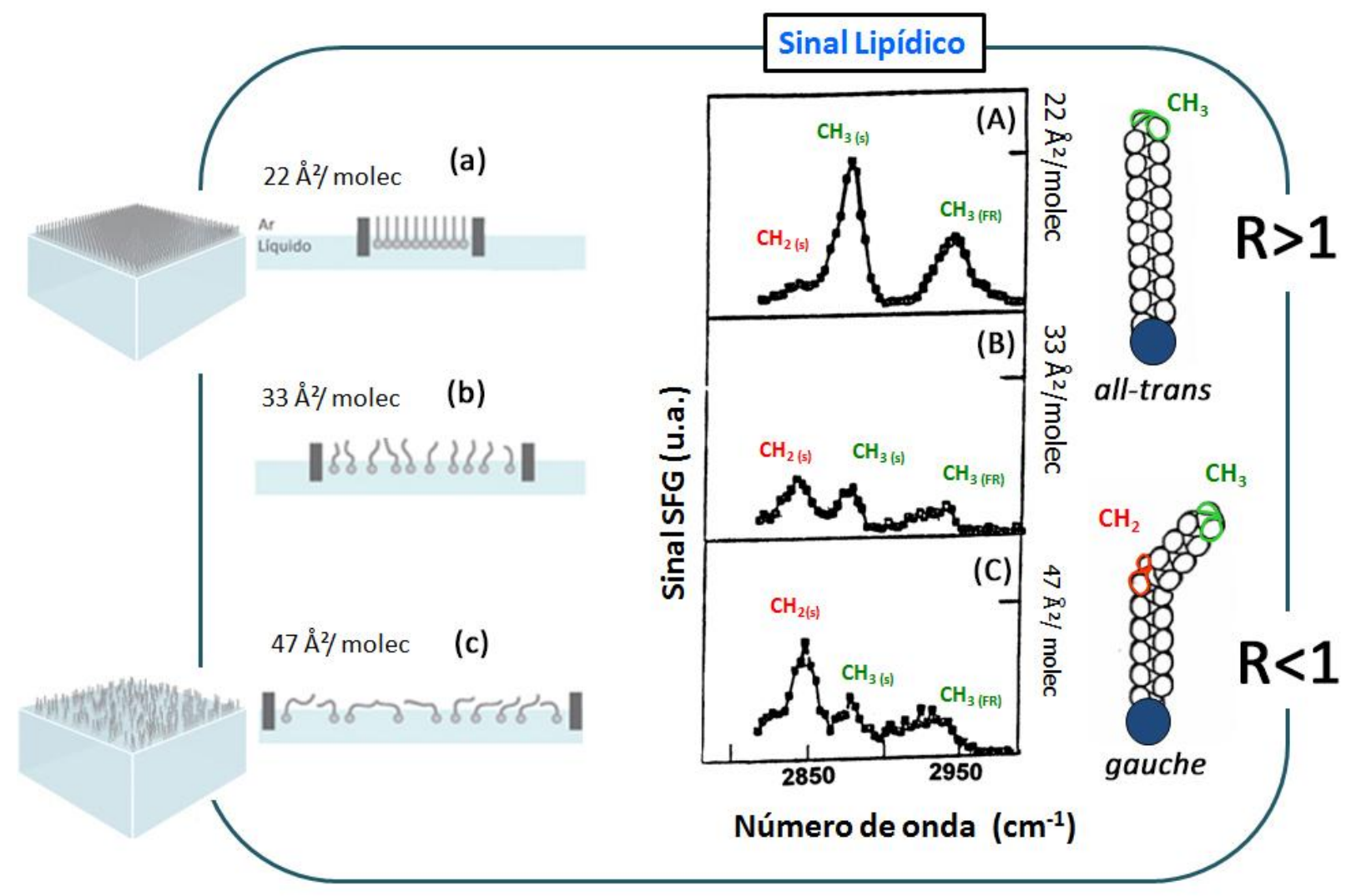

Fonte: Adaptada de GUYOT-SIONNEST; HUNT; SHEN ${ }^{71}$; BIOLIN SCIENTIFIC ${ }^{103}$.

Considere o caso em que os lipídeos estão muito empacotados (FIGURA 26.a). Neste caso, por não terem muito espaço disponível, a maioria dos lipídeos permanece na conformação molecular denominada all-trans (FIGURA 26.a), em que todos os grupos de metileno $\left(-\mathrm{CH}_{2}\right)$ da cauda hidrofóbica estão na conformação trans (abreviação: trans- 
$\mathrm{CH}_{2}$ ). Lembre-se que na Espectroscopia SFG não se detecta sinais vibracionais de meios centrossimétricos. Portanto, pelo fato de grupos trans $-\mathrm{CH}_{2}$ estarem dispostos centrossimetricamente ao longo da cadeia e também vibrarem no plano paralelo à interface (isotrópico), o sinal obtido dos grupos $\mathrm{CH}_{2}$ é praticamente nulo (FIGURA 26.A). Em contrapartida, grupos metila $\left(-\mathrm{CH}_{3}\right)$ estão organizados de modo a quebrar a simetria de inversão ao longo do eixo-z (perpendicular à interface). Logo, todas as vibrações ao longo do eixo-z contribuem fortemente para a geração de sinal SFG (FIGURA 26.A).

Por outro lado, quando analisamos a situação de um filme lipídico muito esparso, em que as caudas lipídicas tem mais espaço para acessar outras conformações na interface (FIGURA 26.c), o espectro SFG muda drasticamente (FIGURA 26.C). Neste caso, há mais lipídeos na conformação gauche, em que há grupos metileno na conformação cis (abreviação cis- $\mathrm{CH}_{2}$ ) (FIGURA 26.C). Consequentemente, as vibrações destes $c i s-\mathrm{CH}_{2} \mathrm{com}$ momento de dipolo ao longo do eixo-z contribuem para o sinal SFG. Logo, a intensidade do sinal SFG do estiramento $\mathrm{CH}_{2}$ simétrico é maior para Filmes de Langmuir pouco empacotados. Além disso, pelo fato de os lipídios terem uma maior liberdade conformacional na interface, os grupos metila $\left(-\mathrm{CH}_{3}\right)$ passam a não ter mais uma orientação preferencial tão ordenada (em relação ao eixo-z) como na situação anterior. Em outras palavras, os grupos $\left(-\mathrm{CH}_{3}\right)$ tem uma distribuição de orientação mais larga, diminuindo o caráter anisotrópico ao longo do eixo-z. Por esta razão, o sinal do grupo $\mathrm{CH}_{3}$ é menor do que o sinal do $\mathrm{CH}_{2}$ para lipídeos pouco empacotados.

Então, se definirmos o Parâmetro R como a razão entre a magnitude do sinal do estiramento $\mathrm{CH}_{3}$ simétrico $\left(\mathrm{CH}_{3(\mathrm{~s})}\right)$ em relação ao do sinal do $\mathrm{CH}_{2}$ simétrico $\left(\mathrm{CH}_{2(\mathrm{~s})}\right)$, ele nos fornece informações a respeito da conformação molecular dos lipídeos na interface e seu empacotamento. Assim, quando $\mathrm{R} \gg>1$ sabemos que os lipídeos estão na conformação all-trans bem empacotados. Já quando $\mathrm{R} \sim 1$, os lipídeos estão na conformação gauche em um estado pouco empacotado. Portanto, o parâmetro R nos fornece informações microscópicas dos Filmes de Langmuir. 


\subsubsection{A Combinação de Polarizações (s, p, s) dos feixes (SFG, VIS, IR)}

Analogamente, a combinação de polarizações SPS mede o $\chi_{y, z, y}^{(2)}$, ou seja, o sinal detectado é proporcional a $\mu_{y}^{\prime}$, o momento de dipolo IR ao longo do eixo-y:

$$
\chi_{s, p, s}^{(2)}=\chi_{y, z, y}^{(2)} \propto A_{q} \propto\left(P_{y z} \cdot Q_{y}\right)_{q} \propto\left(P_{y y} \cdot\left\langle e\left|\mu_{y}^{\prime}\right| g\right\rangle\right)_{q}
$$

Embora seja necessária uma componente do dipolo IR ao longo do eixo y (no plano da interface), como a interface é isotrópica, não se mede sinal se $\mu$ ' está exatamente ao longo do plano-xy. Porém, neste caso, as vibrações com maiores projeções ao longo do eixo-y, isto é, com o dipolo mais próximo ao plano da interface geram sinal.

\subsubsection{A Combinação de Polarizações (p, p, p) dos feixes (SFG, VIS, IR)}

Pela TABELA 09, vemos que combinação de polarizações PPP mede simultaneamente quatro elementos do tensor $\overleftrightarrow{\chi}^{(2)}$. Ou seja, o sinal na combinação de polarizações (p, p, p), $\chi_{p, p, p}^{(2)}$, é proporcional a uma combinação linear de:

$$
\chi_{p, p, p}^{(2)}=c_{1} \cdot \chi_{z, z, z}^{(2)}+c_{2} \cdot \chi_{z, x, x}^{(2)}+c_{3} \cdot \chi_{x, z, x}^{(2)}+c_{4} \cdot \chi_{x, x, z}^{(2)}
$$

em que $c_{1}, c_{2}, c_{3}$ e $c_{4}$ são constantes que dependem da geometria experimental (ângulos de incidência e índices de refração). A interpretação neste caso fica mais complicada, pois contém informação das combinações $(\mathrm{s}, \mathrm{p}, \mathrm{s})$ e (s,s,p), além da contribuição de $\chi_{\mathbf{z z Z}}^{(2)}$ que também está relacionada a vibrações de grupos orientados ao longo do eixo z. 


\section{SEÇÃO EXPERIMENTAL}

\subsection{PREPARAÇÃO DE AMOSTRAS (FILMES DE LANGMUIR)}

Preparamos monocamadas de Langmuir de DPPC (fosfolipídeo zwitteriônico, Avanti Polar Lipids ${ }^{\circledR}, M w=734 \mathrm{~g} / \mathrm{mol}$ ) para simular membranas de células de mamíferos("tipo-humanas"), e Filmes de Langmuir de DPPG (fosfolipídeo carregado negativamente, Avanti Polar Lipids ${ }^{\circledR}, \quad M w=745 \mathrm{~g} / \mathrm{mol}$ ), visando mimetizar as biomembranas de células bacterianas (TABELA 10).

TABELA 10 - FOSFOLIPÍDEOS UTILIZADOS NOS FILMES DE LANGMUIR. Comprados da Avanti Polar Lipids ${ }^{\circledR}$.

\begin{tabular}{|c|c|c|}
\hline \multirow[t]{2}{*}{ (a) } & \multirow[t]{2}{*}{$\begin{array}{l}\text { 1,2-dihexadecanoil-sn-glicero-3-fosfocolina } \\
\text { (DPPC) }\end{array}$} & Cabeça polar: Zwitteriônica ( \pm ) \\
\hline & & $\begin{array}{l}\text { Simula composição de } \\
\text { membranas de células de } \\
\text { mamíferos }\end{array}$ \\
\hline & & mmet \\
\hline \multirow[t]{4}{*}{ (b) } & $\begin{array}{l}\text { 1,2-dihexadecanoil-sn-glicero-3-fosfo-(1'-rac-glicerol) } \\
\text { (DPPG) }\end{array}$ & Cabeça polar: Aniônica (-) \\
\hline & & $\begin{array}{l}\text { Simula composição de } \\
\text { Biomembranas de células } \\
\text { bacterianas }\end{array}$ \\
\hline & & 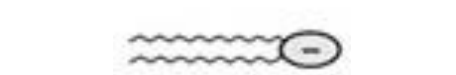 \\
\hline & & DPPG \\
\hline
\end{tabular}

Fonte: Adaptada de AVANTI $^{\circledR} \ldots{ }^{92,93}$.

Preparamos soluções de estoque $(\approx 2 \mathrm{ml})$ de ambos os fosfolipídeos em solventes apolares. A solução de estoque de DPPC $( \pm)$ foi solubilizada em clorofórmio (QHEMIS, 99,8\%) com concentração $C_{\mathrm{DPPC}}=0,74 \mathrm{mg} / \mathrm{ml}$. 0 tempo de evaporação do clorofórmio após espalhar DPPC na cuba foi de 10min (quando subfase era água pura) e de 15min (para solução de antimicrobianos). Já a solução estoque de DPPG(-) foi solubilizada em 
uma mistura clorofórmio:metanol (3:1 v/v, em que o metanol utilizado era da (QHEMIS, $99,8 \%$ ) cuja concentração era $C_{D P P G}=0,44 \mathrm{mg} / \mathrm{ml}$. 0 tempo de evaporação do solvente do DPPG foi de 15min (para subfase aquosa) e de 20min (para subfase com antimicrobianos).

\subsubsection{Detalhes Experimentais da Compressão Isotérmica (\#1)}

Para o estudo de Filmes Langmuir de DPPC $( \pm)$ e de DPPG(-) usando a Metodologia \#1 (compressão isotérmica), nós preparamos três subfases aquosas (FIGURA 27): (i) subfase água ultra pura (Milli-Q, resistividade 18,2 $\mathrm{M} \Omega . \mathrm{cm}, \mathrm{pH}=5,7 \pm 1$ ) para ser a referência (controle); (ii) subfase aquosa de solução de um biopolímero catiônico antimicrobiano que é biocompatível com células humanas: Oligômeros de Quitosana (abreviação: OQ; concentração em Milli-Q $C_{0 Q}=0,03 \mathrm{~g} / \mathrm{l}, \mathrm{pH}=5,9 \pm 1$ ); e (iii) subfase aquosa de solução de um polieletrólito catiônico sintético que é tanto antimicrobiano, quanto tóxico (não biocompatível) às células humanas: o poli(hidrocloreto de alilamina) (abreviação: PAH; concentração em Milli-Q: $\mathrm{C}_{\mathrm{PAH}}=0,03 \mathrm{~g} / \mathrm{l}, \mathrm{pH}=5,9 \pm 1$ ). A compressão isotérmica foi feita (simetricamente) em uma taxa constante de $10 \mathrm{~mm} / \mathrm{min}$. Experimentos de Espectroscopia SFG de filmes de Langmuir em uma dada pressão constante $(30 \mathrm{mN} / \mathrm{m}$ ou $20 \mathrm{mN} / \mathrm{m})$, os filmes também foram comprimidos a $10 \mathrm{~mm} / \mathrm{min}$ até se chegar a pressão de interesse. Depois de se chegar na pressão de interesse, para mantê-la constante, as barreiras faziam um mecanismo de feedback, abrindo e fechando com uma velocidade máxima de $3 \mathrm{~mm} / \mathrm{min}$.

FIGURA 27 - POLIELETRÓLITOS CATIÔNICOS ANTIMICROBIANOS UTILIZADOS. (a) Estrutura química dos

(a) oligômeros de quitosana (OQ). (b) Estrutura química do poli(hidrocloreto de alilamina), $\mathrm{PAH}$.

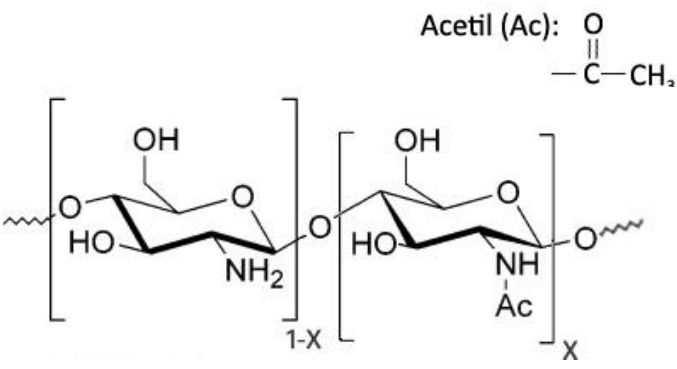

(b)

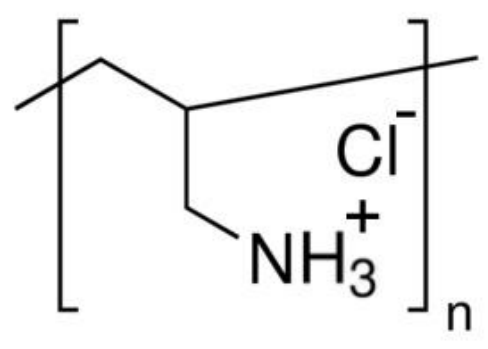

Fonte: Adaptada de GOY; DE BRITTO; ASSIS $^{46} ;$ SIGMA... $^{109}$. 
Os oligômeros de quitosana (OQ) foram comprados da Kitto Life (Coréia do Sul) e caracterizados por ressonância magnética (RMN-H) e por cromatografia por exclusão de tamanho (FIGURA 27.a e 28). 0 grau de acetilação (GA) determinado por RMN-H foi de $\mathrm{GA}=11,0 \pm 0,6 \%$. Ou seja, cerca de $89 \%$ das unidades repetitivas do oligômero sofreram desacetilação (grupos Acetil, Ac, removidos) gerando unidades de glicosamina, GlicN. Portanto, 89\% das unidades do oligômero carregam cargas positivas devido à presença de grupos amina protonadas $\left(-\mathrm{NH}_{3}{ }^{+}\right.$, cujo pKa fica entre 6,2 a 7,0). ${ }^{44}$ Além disso, a cromatografia de exclusão de tamanho forneceu a distribuição de massas moleculares dos OQ (FIGURA 28). Assim, a Massa Molecular Média Ponderara de Mw=2.561g/mol pôde ser determinada. Note que o maior número de moléculas de OQ tem massa entre $900 \mathrm{~g} / \mathrm{mol}$ a $5000 \mathrm{~g} / \mathrm{mol}$. Então, considerando que 89\% da composição dos os oligômeros de quitosana $\left(\mathrm{Mw}_{\mathrm{OQ}}=2561 \mathrm{~g} / \mathrm{mol}\right)$ são de unidades de GlicN protonadas $\left(\mathrm{Mw}_{\mathrm{GlicN}}=\right.$ $161 \mathrm{~g} / \mathrm{mol}$ ), um oligômero de quitosana representativo teria $\approx 14$ unidades GlicN carregadas positivamente e $\approx 1$ unidade neutra de $\mathrm{N}$-acetilglicosamina, NAG, $\left(\mathrm{MW}_{\mathrm{NAG}}=218 \mathrm{~g} / \mathrm{mol}\right)$.

FIGURA 28 - CARACTERIZAÇÃO DOS OLIGÔMEROS DE QUITOSANA (OQ). Em destaque, a distribuição de tamanhos dos OQ. No inset, caracterização por RMN-H. Na estrutura química do monômero ilustrado, $R$ pode ser substituinte -Acetil (para NAG, quitina "pura") ou um hidrogênio $-H$ (para GlicN, quitosana "pura").

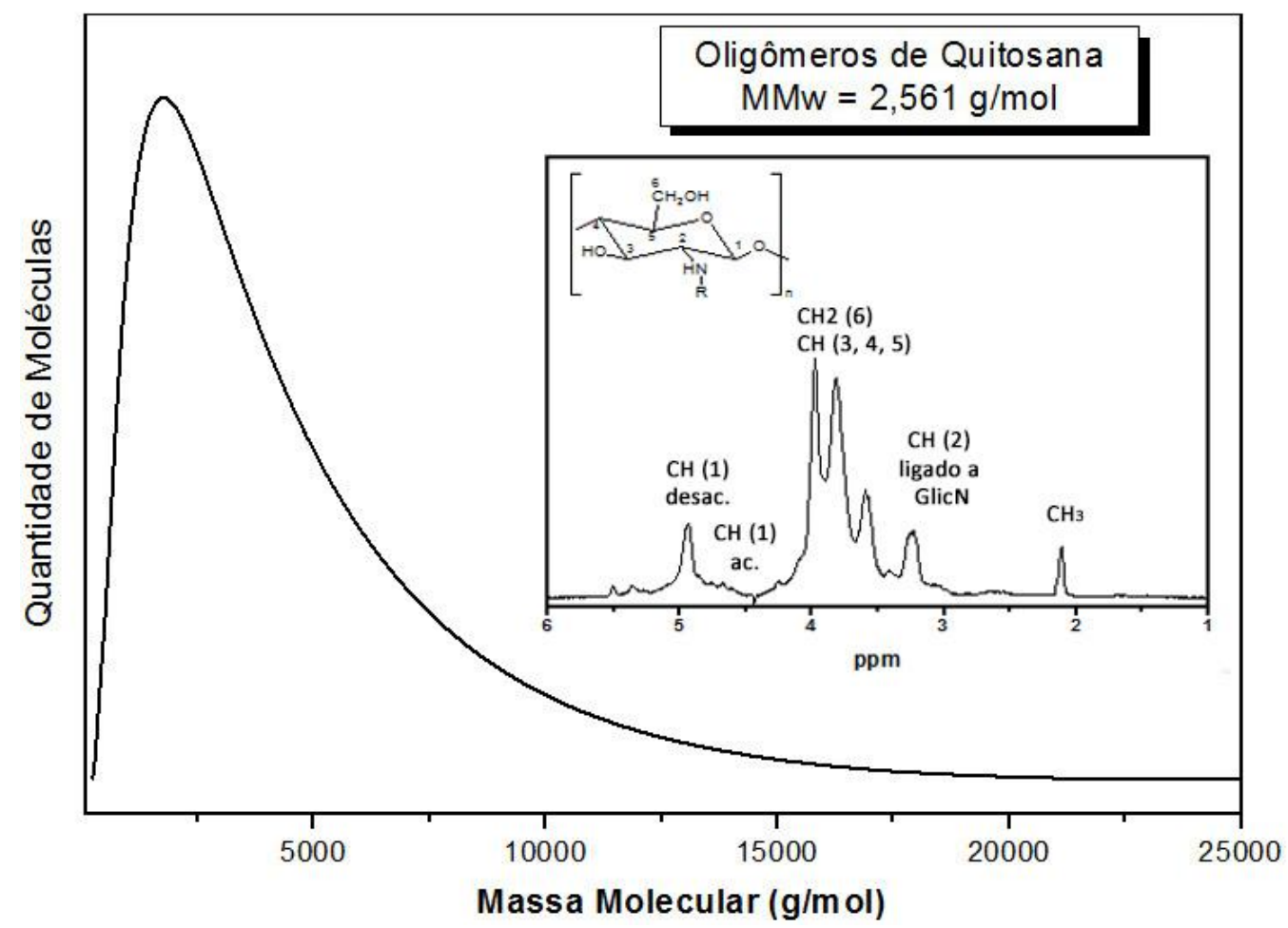

Fonte: Elaborada pelo autor. 
Já o polieletrólito catiônico sintético PAH (SIGMA-Aldrich ${ }^{\circledR}$ ) tem $\mathrm{Mw}=15.000 \mathrm{~g} / \mathrm{mol}$ e, segundo a folha de especificação, o maior número de moléculas de PAH tem massa entre entre $12.000 \mathrm{~g} / \mathrm{mol}$ e $22.500 \mathrm{~g} / \mathrm{mol}$. Neste trabalho, consideramos como "oligômero" polímeros com Mw menor $10.000 \mathrm{~g} / \mathrm{mol}$. Logo, seguindo esta classificação, o PAH não é um oligômero, mas um polímero de baixa massa molecular. Sua estrutura é mostrada na FIGURA 27.b. Considerando que todos os grupos amina do PAH estejam protonados, então uma única molécula de PAH (MwPAH=15.000g/mol) tem

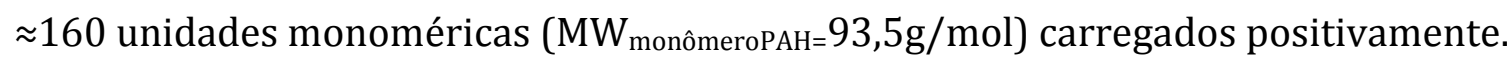

\subsubsection{Detalhes Experimentais da Dinâmica Isobárica (\#2)}

Para estudos de expansão isobárica (metodologia \#2), preparamos soluções estoque $(\approx 1,5 \mathrm{ml})$ muito concentradas de $O Q\left(\mathrm{C}_{o q}{ }^{i n j}=17,5 \mathrm{~g} / \mathrm{l}\right)$. Assim, com 4 injeções de $50 \mu \mathrm{l}$ (total $200 \mu \mathrm{l}$ ) destas soluções na subfase aquosa, toda a cuba $(115 \mathrm{ml})$ teria um número de mols de antimicrobianos equivalente aos experimentos da metodologia \#1. Desta forma, os resultados de termodinâmica de superfície usando a metodologia \#1 (compressão isotérmica) e a metodologia \#2 (expansão isobárica) são comparáveis. Nota: as injeções foram igualmente distribuídas: duas injeções separadas por detrás de cada barreira. 0 processo de fazer essas 4 injeções foi em menos de 1 minuto.

\subsection{LENI - LABORATÓRIO DE ESPECTROSCOPIA NÃO LINEAR DE INTERFACES}

No LENI, Laboratório de Espectroscopia Não Linear de Interfaces (FIGURA 29), há várias estações experimentais de óptica não linear: Espectroscopia por Geração de Segundo Harmônico (Espectroscopia SHG, para níveis eletrônicos); Espectroscopia por Geração de Soma de Frequências (Espectroscopia SFG, para níveis vibracionais); e, recentemente, uma estação de Microscopia-SFG (Imageamento com contraste químico feito por SFG). Em particular, o sistema óptico para Espectroscopia SFG é baseado em um espectrômetro comercial da EKSPLA (Lituânia) cujo esquema dos feixes está detalhado na representação esquemática da FIGURA 30. 
FIGURA 29 - O LABORATÓRIO NÃO LINEAR DE INTERFACES (LENI). Note que podemos estudar a termodinâmica do sistema simultaneamente com Espectroscopia SFG.

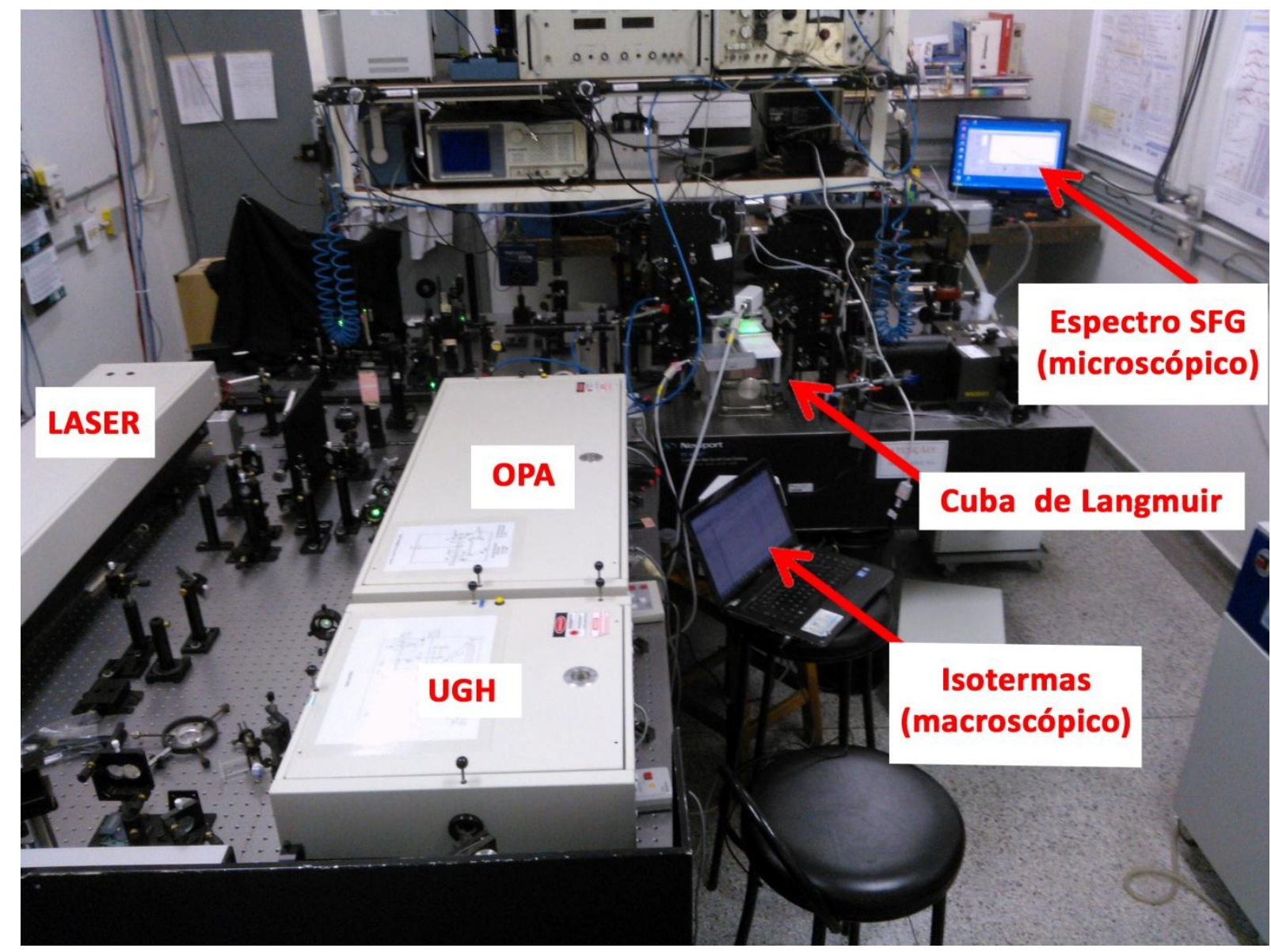

Fonte: Elaborada pelo autor.

\subsubsection{Descrição do Sistema Óptico de Espectroscopia SFG}

Em particular, o sistema óptico para Espectroscopia SFG é um espectrômetro da EKSPLA (Lituânia) cuja representação dos feixes estão detalhados na representado esquemática da FIGURA 30. 


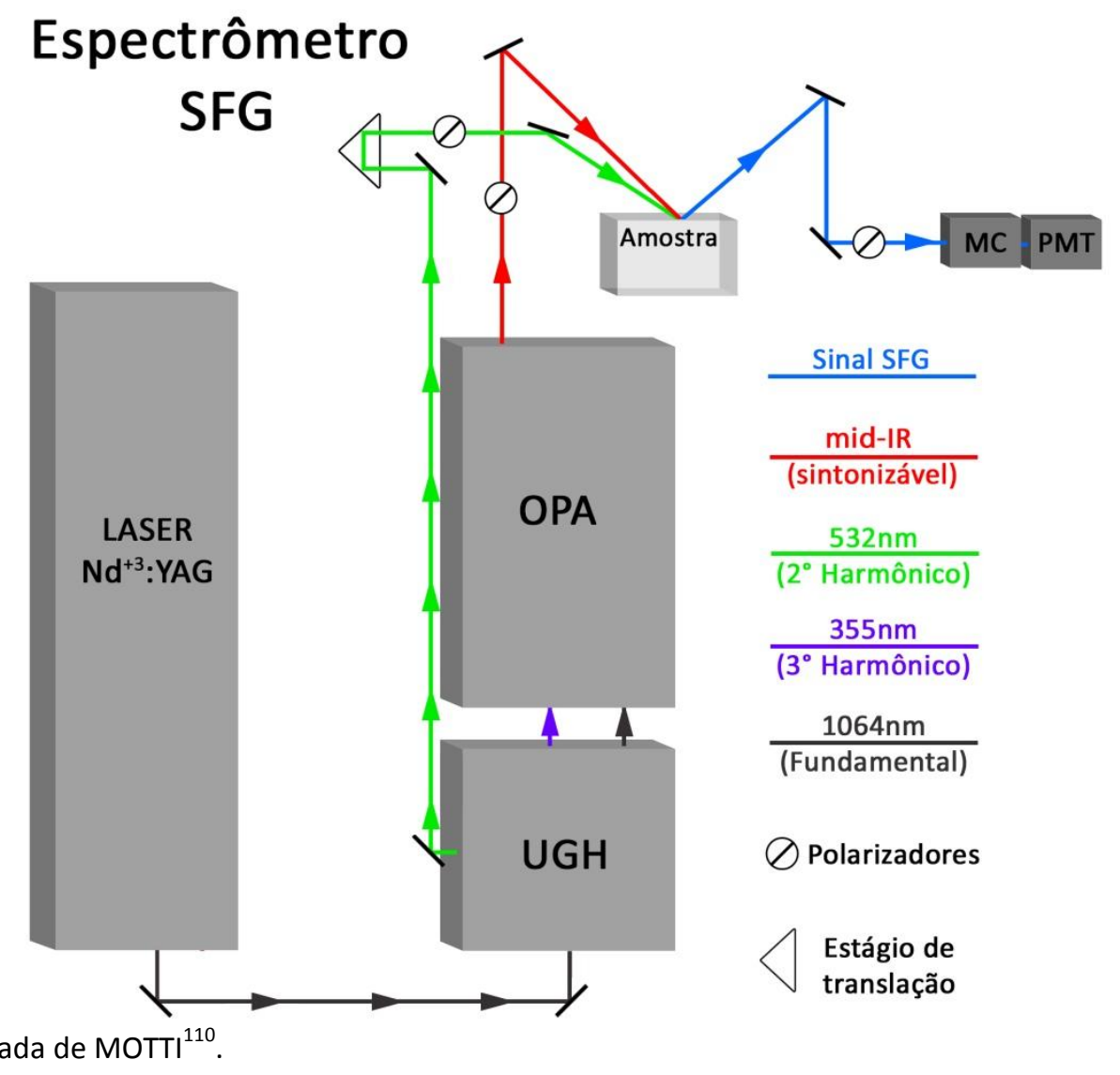

Aqui, o feixe pulsado fundamental do LASER (mode-locked) $\mathrm{Nd}^{+3}$ :YAG (largura temporal do pulso=30ps, taxa de repetição $20 \mathrm{~Hz}$, Energia/pulso=30mJ, comprimento de onda $\lambda=1064 \mathrm{~nm}$ ) passa por uma unidade geradora de harmônicos (UGH) que tem como finalidade produzir um feixe pulsado na região do espectro visível por geração de segundo harmônico ( $\omega_{\text {vis }}$, pulso verde, $\lambda=532 \mathrm{~nm}$, com cerca de $21 \mathrm{ps}$ e $1 \mathrm{~mJ}$ de energia). Este feixe verde será usado para bombear a amostra no processo de soma de frequências. Além do pulso verde, a UGH também produz um feixe na região do ultravioleta (UV) por geração de terceiro harmônico $(\lambda=355 \mathrm{~nm}$, Energia/pulso=7,5mJ). Este pulso de UV, junto com parte do feixe fundamental (Energia=6,0mJ), excitam cristais não lineares dentro do amplificador paramétrico óptico com unidade de geração de diferença de frequências (OPA/DFG) para a geração de um feixe no infravermelho médio sintonizável $\left(\omega_{I R}\right.$, pulso mid-IR, entre $1000 \mathrm{~nm}<\lambda<10.000 \mathrm{~nm}$ ou $10.000 \mathrm{~cm}^{-1}>$ $\tilde{v}>1.000 \mathrm{~cm}^{-1}$, largura da banda do pulso de $\approx 3 \mathrm{~cm}^{-1}$, largura temporal do pulso de $\approx 20 \mathrm{ps,}$ Energia/pulso $\approx 300 \mu \mathrm{J}$ ). Este feixe infravermelho será usado como o segundo feixe a bombear a amostra na geração de soma de frequências na Cuba de Langmuir. 
Tipicamente, o feixe SFG gerado pela interface fica na região do visível ( $\omega_{S F G}$, pulso azul, $\lambda \approx 460 \mathrm{~nm}$ ), e é detectado por uma fotomultiplicadora, após passar por aberturas para diminuir a contribuição de luz espalhada na amostra, e filtros espectrais e um monocromador, para garantir que detectamos apenas o sinal SFG. Antes de fazermos medidas na amostra de interesse em si, nós fazemos a maximização do desempenho do sistema óptico (melhorando o alinhamento óptico) e a sua respectiva calibração em uma amostra de referência (normalização para remover as variações de intensidade e de alinhamento dos feixes, bem como a resposta espectral do sistema de detecção). Idealmente, a amostra de referência deve ter um $\chi_{i, j, k}^{(2)}$ não ressonante (Equação 20) em toda a região espectral de interesse. Note que cada tríade de polarizações (i, j, k) é um experimento diferente e, portanto, requer um Espectro SFG de calibração na amostra de referência para cada conjunto (i, j, k) de interesse.

O alinhamento óptico, em particular, deve levar consideração a sobreposição espacial e temporal dos feixes incidentes (VIS e IR) na amostra. Ou seja, os pulsos IR e VIS têm de chegar no mesmo lugar $E$ ao mesmo tempo. Por esta razão existe um estágio de translação (FIGURA 30) no sistema: com ele podemos controlar o atraso de um pulso em relação ao outro.

Quando há interesse em medir a região espectral entre $2500 \mathrm{~cm}^{-1}$ e $4000 \mathrm{~cm}^{-1}$, por exemplo, para detectar tanto as vibrações da cauda hidrofóbica dos fosfolipídeos (estiramentos $\mathrm{C}-\mathrm{H}$ de grupos alquila $-\mathrm{CH}_{2}$ e $-\mathrm{CH}_{3}$ ), quanto da água interfacial (estiramentos $\mathrm{O}-\mathrm{H}$ ), a amostra de referência que utilizamos foi um cristal de quartzo- $\alpha$ (corte z - eixo óptico perpendicular à superfície). Já para medir os grupos fosfatos da cabeça polar dos fosfolipídeos, na região entre $1000 \mathrm{~cm}^{-1}$ a $1500 \mathrm{~cm}^{-1}$, a amostra de referência que utilizamos foi um filme fino de sulfeto de zinco ( $\mathrm{ZnS}$ ) depositado sobre um substrato de vidro.

Em nossas condições experimentais, em que a espessura da interface é a ordem de $1 \mathrm{~nm}$, a seção de choque dos feixes laser na amostra é da ordem $1 \mathrm{~mm}^{2}$ e a intensidade de pico dos feixes laser é da ordem de $\approx 10^{10} \mathrm{~W} / \mathrm{cm}^{2}$, então a geração de fótons devido a $\vec{P}^{(2)}$ é da ordem de $\approx 10^{4}$ fótons/pulso, o que é facilmente detectável por uma fotomultiplicadora. 


\section{RESULTADOS}

\subsection{ANÁLISE TERMODINÂMICA POR COMPRESSÃO ISOTÉRMICA ( $\pi-\sigma)$}

\subsubsection{Membrana Biomimética "Tipo-Humana”}

Os primeiros experimentos foram com Filmes de Langmuir de DPPC $( \pm)$, que simula membrana de células de humanos utilizando a Metodologia \#1 (compressão isotérmica). ${ }^{111}$ A (FIGURA 31) mostra os resultados do efeito dos Oligômeros de Quitosana (OQ) e do poli(hidrocloreto de alilamina) (PAH) nos filmes de DPPC.

FIGURA 31 - ISOTERMAS EM MEMBRANAS MODELO “TIPO-HUMANAS”.

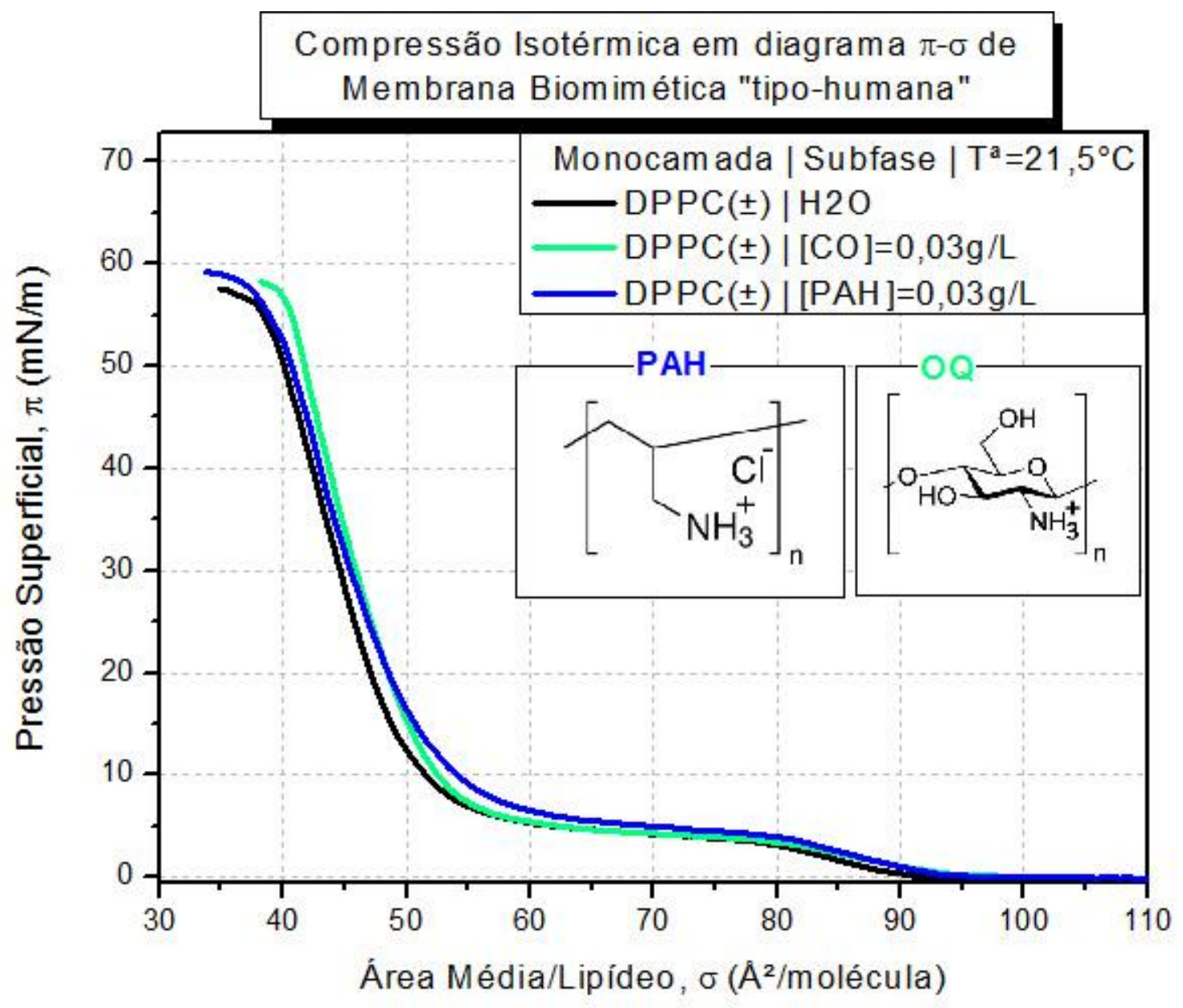

Fonte: Elaborada pelo autor.

Vemos que os OQ e PAH causam uma pequena expansão das isotermas quando comparadas à isoterma de referência (curva controle, linha preta, cuja subfase é água Milli-Q). Essas perturbações sutis são um indício de que os antimicrobianos que estavam solubilizados na subfase se adsorvem na interface líquido-ar na presença de DPPC $( \pm)$. 
Curiosamente, a isoterma dos Oligômeros de Quitosana (OQ, em verde) parece não ter alterado a forma de linha, mas somente transladado à direita (expansão) em relação à curva controle de cerca de $\Delta \sigma \approx 2 \AA^{2}$. Este tipo de resultado, como já discutido na subseção 4.4.2.1 (Interpretação do Diagrama $\pi-\sigma$ ), é equivalente a um experimento de isoterma-controle (cuja subfase não tem OQ) que tem uma concentração maior de lipídeos espalhados na interface. Logo, tal resultado sugere que os OQ se adsorvem na membrana "tipo-humana", causando sua expansão mas sem interferir na interação de um lipídeo com outro no decorrer de toda a compressão isotérmica. Provavelmente, então, essa pequena expansão observada é devido à inserção dos OQ na monocamada, sem alterar interações eletrostáticas locais entre os dipolos permanentes do grupo fosfocolina (fórmula molecular: $\left(\mathrm{CH}_{3}\right)_{3} \mathrm{~N}^{+}\left(\mathrm{CH}_{2}\right)_{2} \mathrm{PO}_{4}^{-}$) da cabeça polar dos DPPCs.

Por outro lado, observa-se no diagrama $\pi-\sigma$ do PAH (em azul) que houve uma sutil mudança na forma de linha, o que sugere que o PAH tem alguma interferência na interação intermolecular entre os lipídeos no decorrer da compressão. Note também que, para $\sigma<55 \AA^{2} /$ molécula, a curva deixa de acompanhar (de ser "paralela" a) o perfil de linha da isoterma-controle. Logo, no começo da compressão, de $\sigma \approx 95 \AA^{2} /$ molécula até $\sigma=55 \AA^{2} /$ molécula, o PAH se comporta como os OQ. A partir daí, a mudança no perfil da linha do PAH sugere que o polieletrólito catiônico começa a interferir na interação intermolecular e no empacotamento lipídico.

Portanto, para pressões superficiais de relevância biológica (por exemplo, $\pi=30 \mathrm{mN} / \mathrm{m}$ ), tais resultados sugerem que ambos os antimicrobianos causam ligeira expansão da monocamada, mas os Oligômeros de Quitosana não interferem na interação entre os lipídeos de membranas que mimetizam células humanas, ao contrário do que acontece com o PAH. 


\subsubsection{Membrana Biomimética "Tipo-Bacteriana”}

Os Filmes de Langmuir de DPPG,112 fosfolipídeo que tem cabeça polar carregada negativamente, foram usados para modelar as biomembranas de bactérias. A FIGURA 32 mostra os resultados de compressão isotérmica (metodologia \#1) a respeito do efeito da presença dos Oligômeros de Quitosana (OQ) e do poli(hidrocloreto de alilamina) (PAH) na subfase aquosa dos filmes de DPPG(-).

Figura 32 - ISOTERMAS EM MEMBRANAS MODELO "TIPO-BACTERIANAS".

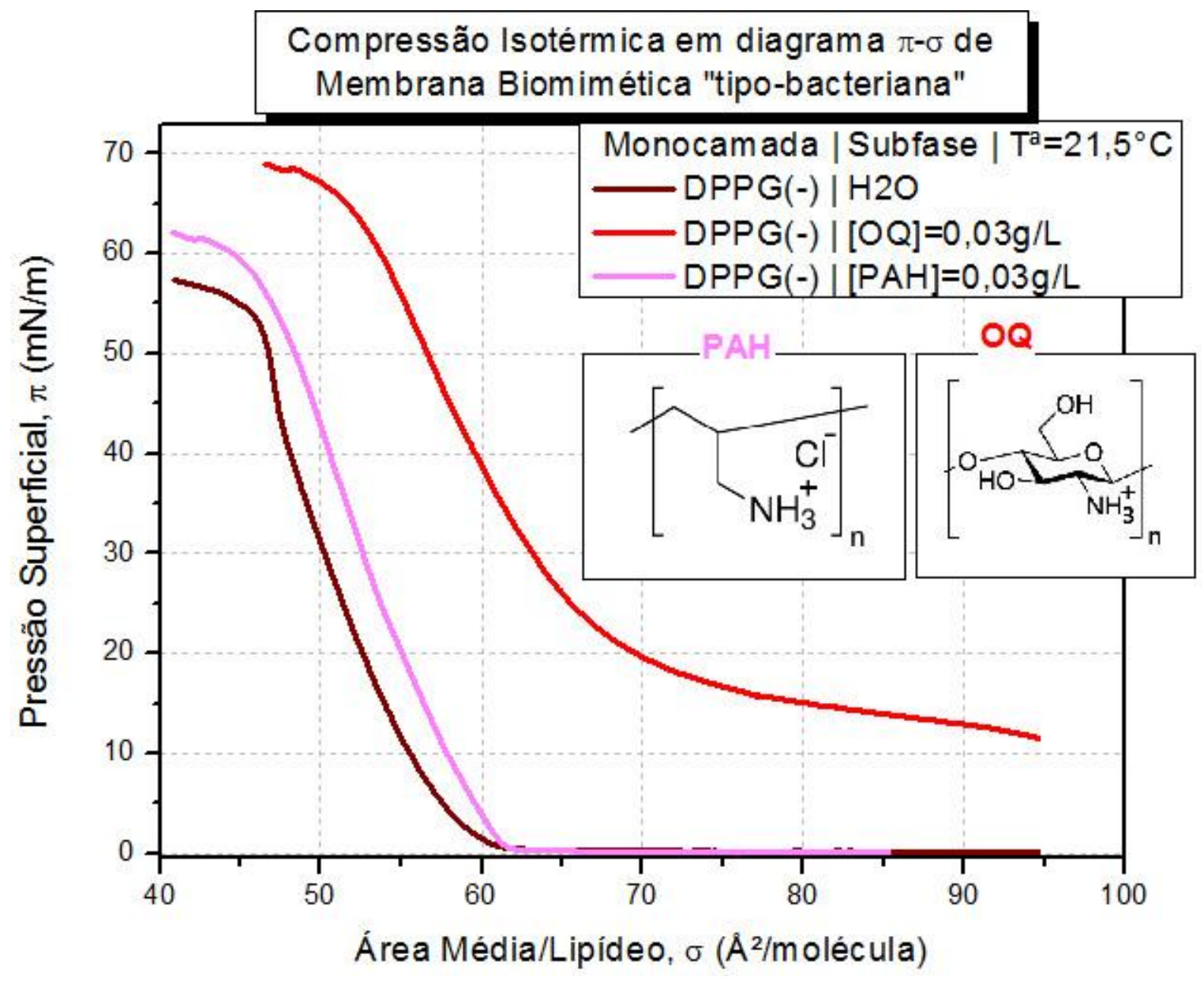

Fonte: Elaborada pelo autor.

Em contraste com as membranas biomiméticas "tipo-humana", as isotermas da (FIGURA 32) evidenciam a forte interação entre os polieletrólitos catiônicos antimicrobianos com membranas biomiméticas "tipo-bacteriana". Muito provavelmente, a atração eletrostática entre os polieletrólitos e a cabeça polar negativa dos fosfolipídeos garante a adsorção dos polieletrólitos à superfície, além de alterar significativamente a interação intermolecular durante a compressão do filme. 
0 diagrama $\pi-\sigma$ dos oligômeros de quitosana (em vermelho), em particular, se destaca muito pela enorme expansão do Filme de DPPG(-). A expansão do filme é tão drástica que, desde o começo da compressão, i.e., já nas primeiras microgotas de solução de DPPG espalhadas sobre a subfase contendo $0 Q$, o sensor de pressão superficial já acusava um valor de $\pi$ muito acima do zero $\left(\pi_{\text {inicial }}=\pi_{0} \approx 12 \mathrm{mN} / \mathrm{m}\right)$. Além disso, para pressões superficiais biologicamente relevantes (por exemplo, $\pi \approx 30 \mathrm{mN} / \mathrm{m}$ ), o aumento de área disponível por lipídeo foi de $\Delta \sigma \approx 13 \AA^{2} /$ molécula. Para se te uma ideia da magnitude disso, um aumento na área de área de $\Delta \sigma \approx 15 \AA^{2} /$ molécula em um Filme de Langmuir de ácido esteárico (um lipídeo que equivale em área a 1 cauda apolar dos fosfolipídeos) é capaz de mudar a conformação de uma fração considerável da população destas moléculas de all-trans para a gauche (cf. FIGURA 26).71 Em outras palavras, se grosso modo considerássemos que a área de um fosfolipídeo (duas caudas hidrofóbicas) fosse o dobro da de um ácido graxo (uma cauda hidrofóbica), esperamos que uma boa parte das moléculas de DPPG na interface tenha pelo menos 1 das caudas na conformação gauche devido a esta expansão de $\Delta \sigma \approx 13 \AA^{2} / \mathrm{molécula} \mathrm{a} \pi \approx 30 \mathrm{mN} / \mathrm{m}$.

Por outro lado, quando analisamos a curva de PAH (em rosa), vemos que a interação deste polieletrólito catiônico com os fosfolipídeos da interface depende da formação de regiões densamente empacotadas de DPPG(-) na interface. Note que a pressão superficial da curva rosa (PAH) só cresce quando a curva em vinho $\left(\mathrm{H}_{2} \mathrm{O}\right)$ cresce. A expansão máxima no filme lipídico causado pelo PAH foi pequena, cerca de $\Delta \sigma \approx 3 \AA^{2} /$ molécula.

\subsection{ANÁLISE MOLECULAR POR ESPECTROSCOPIA SFG}

\subsubsection{Atribuições Ressonantes e Números de Onda Esperados}

Aqui listamos algumas atribuições envolvidas no nosso sistema (cauda hidrofóbicas e grupos fosfato das cabeças polares dos fosfolípideos, estiramentos da água e dos antimicrobianos OQ e PAH). 
TABELA 11 - ESTIRAMENTOS $\left(\mathrm{PO}_{2}\right)$ - DO GRUPO FOSFATO $\left(\mathrm{PO}_{4}\right)$ -

\begin{tabular}{|c|c|c|}
\hline \multicolumn{2}{|r|}{ Cabeça Polar dos Fosfolipídeos } & $\begin{array}{c}\text { Região Espectral } \\
\left(1000 \mathrm{~cm}^{-1} \text { a } 1500 \mathrm{~cm}^{-1}\right)\end{array}$ \\
\hline Modo & Descrição & Número de onda $\left(\mathrm{cm}^{-1}\right)$ \\
\hline \multicolumn{3}{|c|}{ Fosfolipídeos em Fase Líquido-Cristalina: Estiramentos Simétricos $\left(\mathrm{PO}_{2}\right)^{-}$} \\
\hline$\left(\mathrm{PO}_{2}\right)^{-}(\mathrm{s}, \mathrm{lc})$ & Estiramento Simétrico $\left(\mathrm{PO}_{2}\right)$ - (em fase Líquido-cristalina) & $1080<\tilde{v}<1100$ \\
\hline$\left(\mathrm{PO}_{2}\right)^{-}(\mathrm{s}, \mathrm{lc})-\mathrm{d}$ & $\begin{array}{c}\text { Estiramento Simétrico }\left(\mathrm{PO}_{2}\right) \text { - (em fase Líquido-cristalina, com } \\
\text { Cabeças Polares totalmente Desidratadas) }\end{array}$ & $1085<\tilde{v}<1105$ \\
\hline \multicolumn{3}{|c|}{ Fosfolipídeo Fase Líquido-Cristalina: Estiramentos Antissimétricos $\left(\mathrm{PO}_{2}\right)^{-}$} \\
\hline$\left(\mathrm{PO}_{2}\right)^{-}(\mathrm{A}, \mathrm{IC})$ & Estiramento Antissimétrico $\left(\mathrm{PO}_{2}\right)$ - (em fase líquido-cristalina) & $1215<\tilde{v}<1260$ \\
\hline$\left(\mathrm{PO}_{2}\right)^{-}(\mathrm{A}, \mathrm{IC})-\mathrm{h}$ & $\begin{array}{c}\text { Estiramento Antissimétrico }\left(\mathrm{PO}_{2}\right) \text { - (em fase líquido-cristalina, com } \\
\text { Cabeças Polares totalmente Hidratadas) }\end{array}$ & $1220<\tilde{v}<1225$ \\
\hline$\left(\mathrm{PO}_{2}\right)^{-}(\mathrm{A}, \mathrm{IC})-\mathrm{d}$ & $\begin{array}{c}\text { Estiramento Antissimétrico }\left(\mathrm{PO}_{2}\right) \text { - (fase líquido-cristalina, com } \\
\text { Cabeças Polares totalmente Desidratadas) }\end{array}$ & $\sim 1250$ \\
\hline \multicolumn{3}{|c|}{ Fosfolipídeo Fase Líquido-Cristalina: Estiramentos do C'-O-P -O-C } \\
\hline$C^{\prime}-\mathrm{O}-\mathrm{P}$ & Estiramentos tipo $\mathrm{C}^{\prime}-\mathrm{O}-\mathrm{P}-\mathrm{O}-\mathrm{C}$ & $\sim 1068$ \\
\hline $\mathrm{P}-\mathrm{O}-\mathrm{C}$ & Estiramentos tipo $\mathrm{C}^{\prime}-\mathrm{O}-\mathrm{P}-\mathrm{O}-\mathrm{C}$ & $\sim 1050$ \\
\hline \multicolumn{3}{|c|}{ Fosfolipídeos em Fase Cristalina: decomposição dos modos $1068 \mathrm{~cm}^{-1}$ e $1090 \mathrm{~cm}^{-1}$} \\
\hline$\left(\mathrm{PO}_{2}\right)^{-}(\mathrm{s}, \mathrm{c})$ & Estiramento Simétrico $\left(\mathrm{PO}_{2}\right)$ - (em fase cristalina) & $\sim 985$ \\
\hline$\left(\mathrm{PO}_{2}\right)_{(\mathrm{s}, \mathrm{c})}^{-}$ & Estiramento Simétrico $\left(\mathrm{PO}_{2}\right)$ - (em fase cristalina) & $\sim 1035$ \\
\hline$\left(\mathrm{PO}_{2}\right)_{(\mathrm{s}, \mathrm{c})}^{-}$ & Estiramento Simétrico $\left(\mathrm{PO}_{2}\right)$ - (em fase cristalina) & $\sim 1060$ \\
\hline$\left(\mathrm{PO}_{2}\right)_{(\mathrm{s}, \mathrm{c})}^{-}$ & Estiramento Simétrico $\left(\mathrm{PO}_{2}\right)$ - (em fase cristalina) & $\sim 1080$ \\
\hline$\left(\mathrm{PO}_{2}\right)^{-}(\mathrm{s}, \mathrm{c})$ & Estiramento Simétrico $\left(\mathrm{PO}_{2}\right)$ - (em fase cristalina) & $\sim 1105$ \\
\hline$\left(\mathrm{PO}_{2}\right)^{-}(\mathrm{s}, \mathrm{c})$ & Estiramento Simétrico $\left(\mathrm{PO}_{2}\right)$ - (em fase cristalina) & $\sim 1122$ \\
\hline
\end{tabular}

Fonte: Adaptada de GARIDEL; BLUME; HU. ${ }^{113}$

TABELA 12 - ESTIRAMENTOS DE GRUPOS ALQUILA. Em verde e em vermelho os estiramentos relacionados ao Parâmetro R para medir conformações lipídicas.

\begin{tabular}{|c|c|c|}
\hline \multicolumn{2}{|r|}{ Caudas Hidrofóbicas dos Lipídeos } & \multirow{2}{*}{$\begin{array}{c}\text { Região Espectral } \\
\left(2800 \mathrm{~cm}^{-1} \text { a } 3000 \mathrm{~cm}^{-1}\right) \\
\text { Número de onda }\left(\mathrm{cm}^{-1}\right.\end{array}$} \\
\hline Modo & Descrição & \\
\hline $\mathrm{CH}_{3(\mathrm{~s})}$ & Estiramento Simétrico do $\mathrm{CH}_{3}$ & $\sim 2878$ \\
\hline $\mathrm{CH}_{3(\mathrm{~S}, \mathrm{FR})}$ & Estiramento Simétrico do $\mathrm{CH}_{3}$ (Ressonância de Fermi) & $\sim 2945$ \\
\hline $\mathrm{CH}_{3(\mathrm{AS}, \mathrm{np})}$ & Estiramento Antissimétrico no plano & $\sim 2962$ \\
\hline $\mathrm{CH}_{3(\mathrm{AS}, \mathrm{fp})}$ & Estiramento Antissimétrico fora do plano & $\sim 2952$ \\
\hline $\mathrm{CH}_{2(\mathrm{~s})}$ & Estiramento Simétrico do $\mathrm{CH}_{2}$ & $\sim 2846$ \\
\hline $\mathrm{CH}_{2(\mathrm{~S}, \mathrm{FR})}$ & Estiramento Simétrico do $\mathrm{CH}_{2}$ (Ressonância de Fermi) & $\sim 2890$ \\
\hline $\mathrm{CH}_{2(\mathrm{AS})}$ & Estiramento Assimétrico do $\mathrm{CH}_{2}$ & $\sim 2920$ \\
\hline
\end{tabular}

Fonte: Adaptada de SILVA ${ }^{107}$

TABELA 13 - ESTIRAMENTOS DE O-H DA ÁGUA.

\begin{tabular}{|c|c|c|}
\hline \multicolumn{2}{|r|}{ Moléculas de água interfaciais } & $\begin{array}{c}\text { Região Espectral } \\
\left(3000 \mathrm{~cm}^{-1} \text { a } 3800 \mathrm{~cm}^{-1}\right)\end{array}$ \\
\hline Modo & Descrição & Número de onda $\left(\mathrm{cm}^{-1}\right)$ \\
\hline $\mathrm{O}-\mathrm{H}(\mathrm{S}, \mathrm{g})$ & Estiramento Simétrico do O-H (tipo gelo, fortes ligações-H) & $\sim 3250( \pm 100)$ \\
\hline $\mathrm{O}-\mathrm{H}(\mathrm{S}, \mathrm{I})$ & Estiramento Simétrico do O-H (tipo líquido, com ligações-H) & $\sim 3450( \pm 100)$ \\
\hline $\mathrm{O}-\mathrm{H}(\mathrm{S}, \mathrm{v})$ & Estiramento Simétrico do O-H (tipo vapor, poucas ligações-H) & $\sim 3680( \pm 30)$ \\
\hline
\end{tabular}

Fonte: Adaptada de DU et al. ${ }^{70}$ 
TABELA 14 - ESTIRAMENTOS TÍPICOS DOS POLIELETRÓLITOS ANTIMICROBIANOS

\begin{tabular}{|c|c|c|c|}
\hline \multicolumn{3}{|c|}{ Grupos só dos polieletrólitos (PAH ou OQ) } & $\begin{array}{c}\text { Região Espectral } \\
\left(1000 \mathrm{~cm}^{-1} \text { a } 3800 \mathrm{~cm}^{-1}\right)\end{array}$ \\
\hline Modo & Molécula & Descrição & Número de onda $\left(\mathrm{cm}^{-1}\right)$ \\
\hline $\mathrm{N}-\mathrm{H}_{(\mathrm{S})}$ & $\mathrm{PAH} / \mathrm{OQ}$ & Estiramentos simétricos de $\mathrm{N}-\mathrm{H}$ & $3100<\tilde{v}<3400$ \\
\hline $\mathrm{N}-\mathrm{H}_{(\mathrm{AS})}$ & $\mathrm{PAH} / \mathrm{OQ}$ & Estiramentos antisimétricos de $\mathrm{N}-\mathrm{H}$ & $3300<\tilde{v}<3500$ \\
\hline $\mathrm{C}-\mathrm{O}$ & $\mathrm{OQ}$ & Estiramento do Metileno Acetal O-C-O & $\sim 1040$ \\
\hline
\end{tabular}

Fonte: Adaptada de TIPSON. ${ }^{11}$

\subsubsection{Espectros SFG das Caudas Lipídicas e da Água Interfacial}

\subsubsection{Interações Moleculares em Membrana “Tipo-Humana”}

Apresentamos aqui os efeitos da interação dos polieletrólitos catiônicos antimicrobianos em Filmes de Langmuir de DPPC $( \pm)$ à pressão superficial de $\pi=30 \mathrm{mN} / \mathrm{m}$. Nestes experimentos, espalhamos os fosfolipídeos em diferentes subfases $\left(\mathrm{H}_{2} \mathrm{O},[\mathrm{OQ}]=0,03 \mathrm{~g} / \mathrm{l}\right.$ e $\left.[\mathrm{PAH}]=0,03 \mathrm{~g} / \mathrm{l}\right)$, comprimimos as barreiras até $\pi=30 \mathrm{mN} / \mathrm{m}$, mantendo esta constante a longo de todo o experimento. Os espectros SFG dos lipídeos e da água interfacial na região dos estiramentos $\mathrm{CH}$ e $\mathrm{OH}$ estão mostrados na (FIGURA 33).

FIGURA 33 - ESPECTROS SFG DE MEMBRANA ( $\pi=30 \mathrm{mN} / \mathrm{m})$ "TIPO-HUMANA" - PARTE 1.

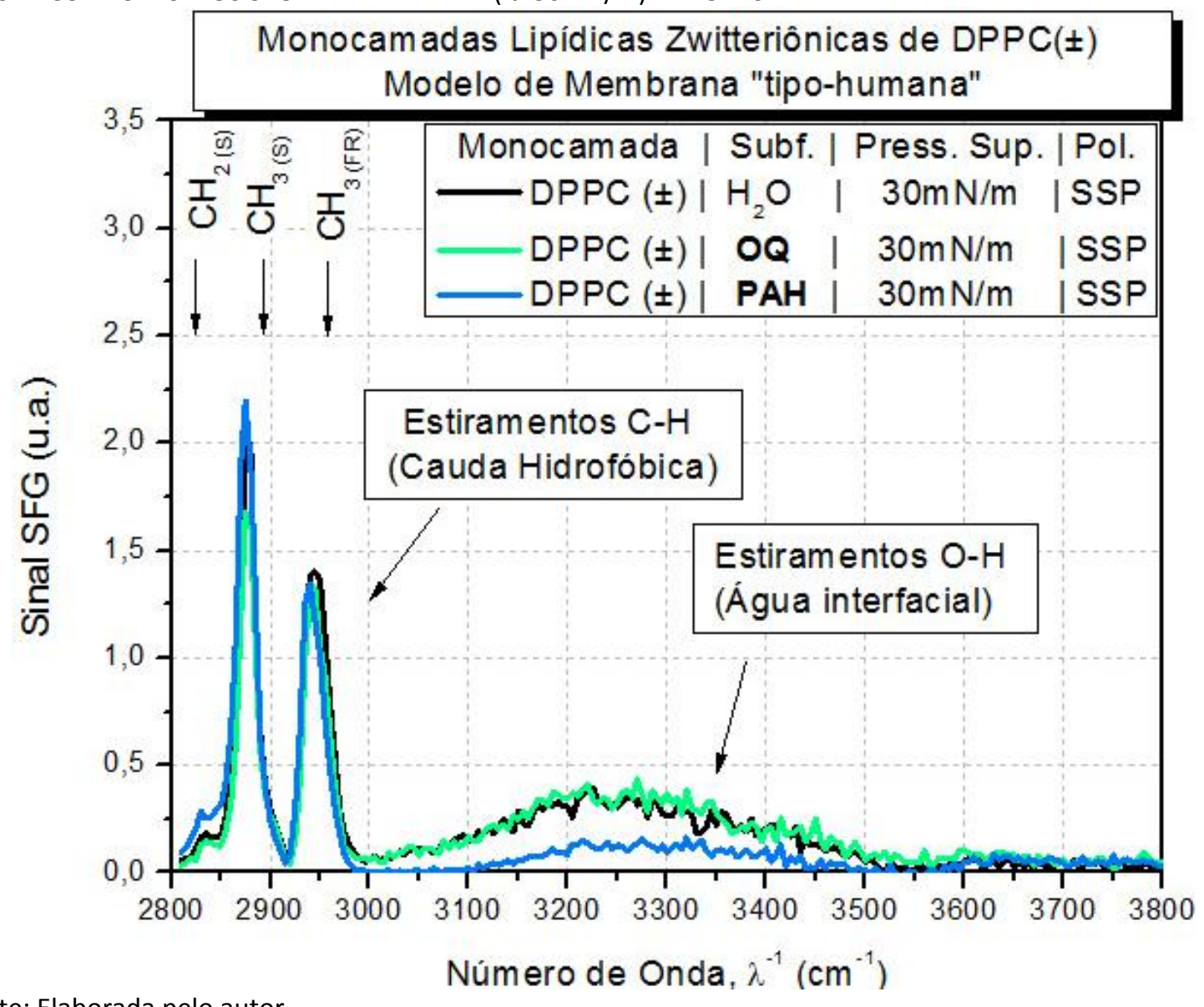

Fonte: Elaborada pelo autor. 
Comparando a curva em preto (controle) com a em verde (OQ), vemos claramente na FIGURA 33 que os Oligômeros de Quitosana causam nenhuma mudança nos modos vibracionais SFG de Filmes de Langmuir de DPPC $( \pm)$ em $\pi=30 \mathrm{mN} / \mathrm{m}$, que mimetizam membranas "tipo-humanas". Este resultado está coerente com a literatura, uma vez que os biopolímeros de quitosana são macromoléculas consideradas biocompatíveis. Inclusive, os estiramentos $\mathrm{O}-\mathrm{H}$ das moléculas de água interfaciais não são alterados. Isso é um indicativo de que não houve uma mudança na orientação média e na rede de ligações de hidrogênio ${ }^{70-74}$ entre as moléculas de água: elas mantém suas interações com os fosfolipídeos zwitteriônicos da mesma forma como se não existisse oligômeros de quitosana na subfase. Este resultado está coerente com os dados do Diagrama $\pi-\sigma$ da (FIGURA 31), em que uma subfase com OQ não causam nenhuma alteração no perfil de linha da isoterma de DPPC em água.

Por outro lado, a curva em azul da FIGURA 33, que diz respeito ao espectro SFG de Filmes de Langmuir de $\operatorname{DPPC}( \pm)$ quando a subfase é uma solução aquosa contendo $\mathrm{PAH}$, evidencia uma sutil mudança nas interações da água interfacial com os fosfolipídeos zwitteriônicos. Note que a magnitude do sinal dos estiramentos $\mathrm{OH}$ diminuiu, um indicativo de que as moléculas de água estão menos orientadas, visto que muito provavelmente o PAH adsorvido na monocamada de DPPC reduziu a magnitude do potencial da membrana (no mínimo, tornou-se menos negativo). Ademais, os picos de Ressonância de Fermi do grupo metila $\left(\mathrm{CH}_{3(\mathrm{FR})} \approx 2950 \mathrm{~cm}^{-1}\right)$ e o pico largo das moléculas de água (centralizado em $0-\mathrm{H} \approx 3250 \mathrm{~cm}^{-1}$ ) aparentam se afastar um do outro, sugerindo uma possível interferência destrutiva do sinal SFG entre esses picos. Outro argumento a favor desta hipótese é que o sinal SFG é zero entre $3000 \mathrm{~cm}^{-1}$ e $3100 \mathrm{~cm}^{-1}$. Sendo este o caso, as moléculas de água na interface invertem de orientação quando sob a presença de PAH (FIGURA 34). Talvez a adsorção do PAH tenha não apenas compensado a carga negativa dos lipídeos, mas "supercompensado" a carga negativa inicial devido ao excesso de cargas positivas da cadeia mais longa desse polieletrólito. Assim, diferentemente dos OQ, o PAH consegue se adsorver na monocamada de DPPC $( \pm)$ de forma enovelada, que acaba por trazer à interface mais carga positiva que aquela que interage diretamente com os grupos polares dos lipídeos. Isso resulta em uma inversão da carga total da interface e do sentido do campo elétrico que orienta as moléculas de água na dupla camada elétrica. 
Note também que nesta pressão, $\pi=30 \mathrm{mN} / \mathrm{m}$, o parâmetro $\mathrm{R}$, que é a razão entre picos da cauda hidrofóbica $\left(\mathrm{CH}_{3} / \mathrm{CH}_{2}\right)$ é bem maior que a unidade $(\mathrm{R}>>1)$, indicando que os lipídeos mantêm uma conformação praticamente all-trans na interface em todas as curvas. Logo, nem $\mathrm{OQ}$, nem $\mathrm{PAH}$ alteraram significativamente a conformação dos lipídeos na interface. Em todos os casos, os DPPCs $( \pm)$ permanecem bem empacotados. Portanto, o modelo de interação molecular desses polieletrólitos em membranas biomiméticas "tipo-humanas" é conforme ilustra a FIGURA 34.

FIGURA 34 - MECANISMO DE INTERAÇÃO EM MEMBRANAS TIPO-HUMANA. PARTE 1: Analisando empacotamento das caudas lipídicas hidrofóbicas e as mudanças no potencial de membrana ( $\mathrm{H}_{2} \mathrm{O}$ interfaciais).

(a) Membrana Tipo-Humana sobre subfase de $\mathrm{H}_{2} \mathrm{O}$ pura (controle) - Pt 1.

\section{$\operatorname{DPPC}( \pm)$}

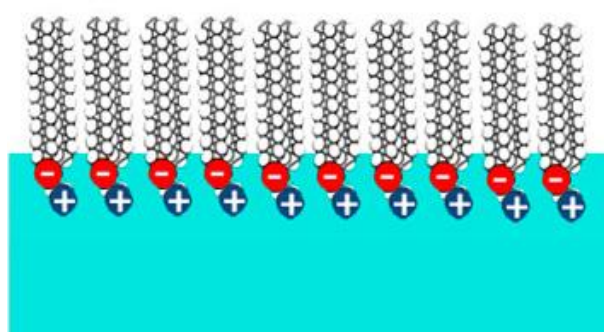

POTENCIAL DE MEMBRANA

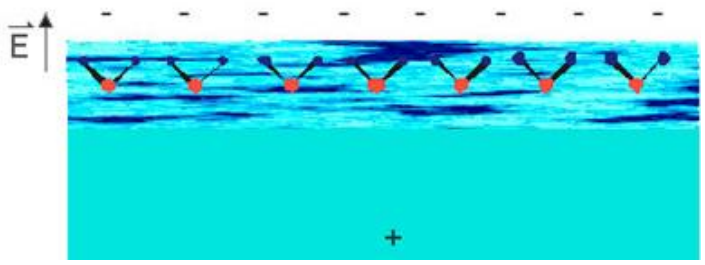

(b) Membrana Tipo-Humana sobre subfase com oligômeros de quitosana (OQ) - Pt 1.

$\operatorname{DPPC}( \pm)$

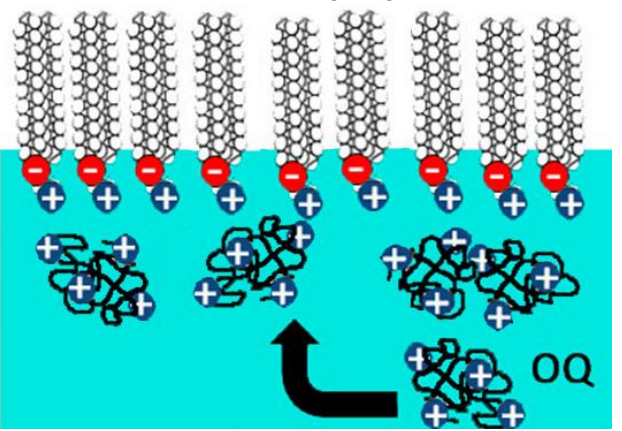

POTENCIAL DE MEMBRANA

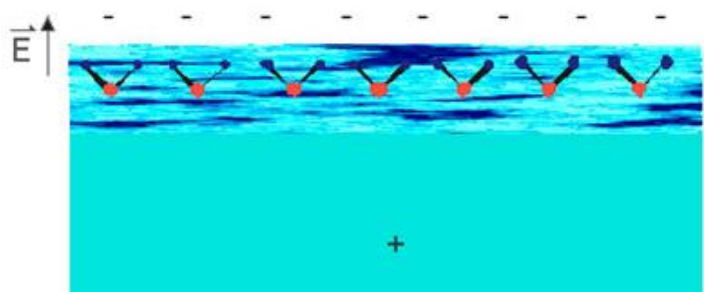

(c) Membrana Tipo-Humana sobre subfase com poli(hidrocloreto de alilamina) (PAH) - Pt 1.

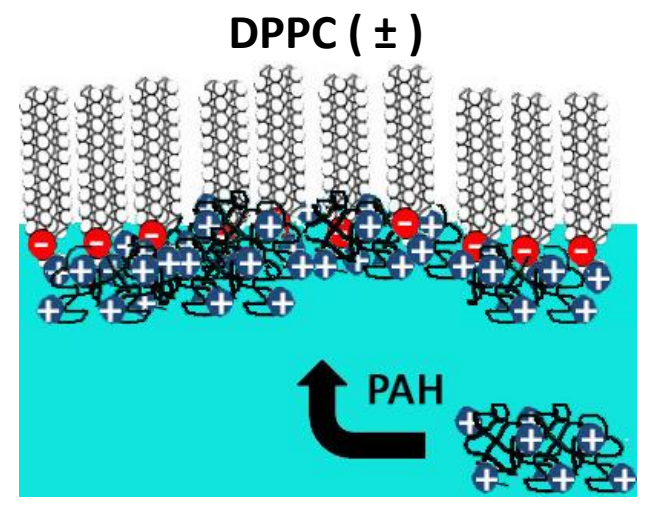

POTENCIAL DE MEMBRANA

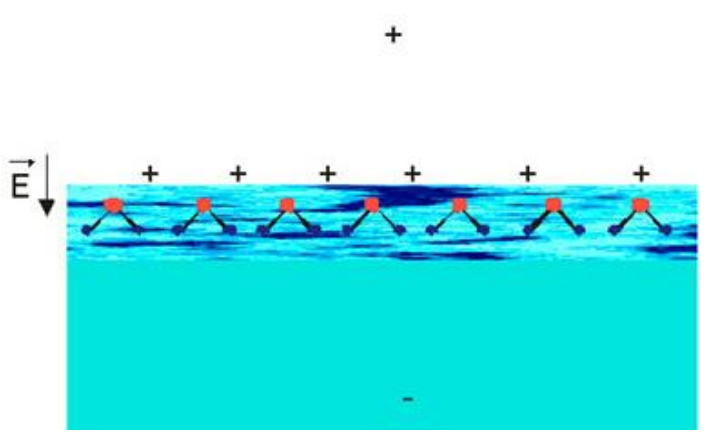

Fonte: Elaborada pelo autor. 


\subsubsection{Interações Moleculares em Membrana "Tipo-Bacteriana”}

A FIGURA 35 apresenta os efeitos da interação dos polieletrólitos catiônicos antimicrobianos em Filmes de Langmuir de $\operatorname{DPPG(-)}$ à pressão superficial de $\pi=30 \mathrm{mN} / \mathrm{m}$. Nestes experimentos, espalhamos os fosfolipídeos nas seguintes subfases $\left(\mathrm{H}_{2} \mathrm{O},[\mathrm{OQ}]=0,03 \mathrm{~g} / \mathrm{l}\right.$ e $\left.[\mathrm{PAH}]=0,03 \mathrm{~g} / \mathrm{l}\right)$, comprimimos as barreiras até $\pi=30 \mathrm{mN} / \mathrm{m}$ e mantivemos esta pressão constante durante a aquisição dos espectro SFG.

FIGURA 35 - ESPECTROS SFG DE MEMBRANA ( $\pi=30 \mathrm{mN} / \mathrm{m})$ “TIPO-BACTERIANA" - PARTE 1.

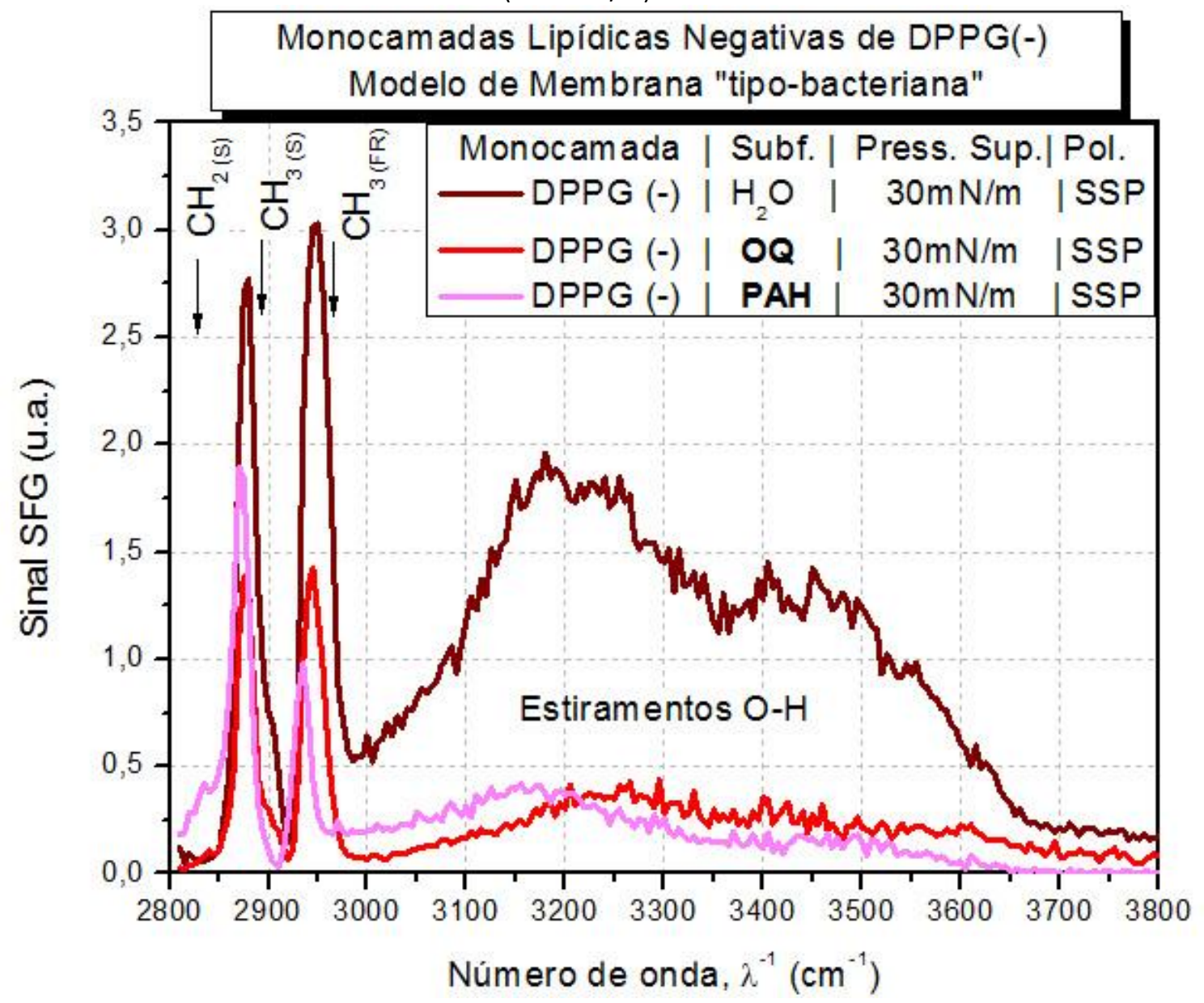

Fonte: Elaborada pelo autor.

Ao compararmos as curvas vermelha (OQ) e a rosa (PAH) com a curva em vinho $\left(\mathrm{H}_{2} \mathrm{O}\right.$, controle), vemos uma nítida queda no sinal SFG dos estiramentos $\mathrm{O}-\mathrm{H}$ devido à presença de polieletrólitos catiônicos na interface líquido-ar. Essa drástica redução de sinal está diretamente relacionada à queda do potencial elétrico da membrana. A redução do potencial, por sua vez, é causada pelo efeito de blindagem das cargas negativas do lipídeo pelas cargas positivas dos polieletrólitos antimicrobianos 
adsorvidos na interface, reduzindo o comprimento de penetração do campo elétrico na dupla camada (comprimento de Debye). ${ }^{107}$ Por conseguinte, menos moléculas de água interfaciais ficam com uma orientação preferencial na interface (i.e., estão mais randomicamente distribuídas na interface), causando uma redução do sinal SFG.

Além disso, um aspecto interesse de se notar na curva controle $\left(\mathrm{H}_{2} \mathrm{O}\right.$, curva de cor vinho) é que o sinal das vibrações das águas interfaciais é tão intenso que a cauda do seu pico causa uma interferência construtiva com a vibração de Ressonância de Fermi do grupo metila de $\left(\mathrm{CH}_{3(\mathrm{FR})}\right)$ do lipídeo. Observe que, consequentemente, a amplitude do pico $\mathrm{CH}_{3(\mathrm{FR})}$ é maior que a amplitude de estiramento simétrico $\left(\mathrm{CH}_{3(\mathrm{~S})}\right)$, diferentemente do que acontece com o DPPC( \pm ) em água pura ( $c f$. FIGURA 33). Ademais, o efeito de blindagem de cargas de ambos os polieletrólitos diminui o sinal da água que, por conseguinte, diminui esta interferência construtiva, fazendo com que o sinal $\mathrm{CH}_{3 \text { (FR) }}$ seja menor que o sinal $\mathrm{CH}_{3(\mathrm{~S})}$ nas curvas de solução de PAH e de CO na subfase. Novamente, a alteração da forma de linha do espectro do DPPG interagindo com a solução de PAH (curva rosa) em relação aos outros dois espectros, especialmente na região entre o pico $\mathrm{CH}_{3(\mathrm{FR})}$ ) e a banda dos estiramentos $\mathrm{OH}$, sugere que a adsorção de PAH foi capaz de inverter a carga interfacial líquida de negativa para ligeiramente positiva, deixando as moléculas de água na interface com orientação oposta.

Talvez a informação mais interessante dos Espectros SFG da (FIGURA 35) está relacionada à conformação dos lipídeos na interface, sobretudo quando sob a ação de Oligômeros de Quitosana (OQ). Nota-se que o parâmetro R de ordenamento molecular é bem maior que a unidade $(\mathrm{R}>>1)$ para todos os espectros. Consequentemente, embora os Oligômeros de Quitosana tenham causado aquela drástica expansão do Filme de Langmuir de DPPG(-) (FIGURA 32) (cerca de $\Delta \sigma \approx 13 \AA^{2} /$ molécula), os lipídeos permanecem bem empacotados na conformação all-trans. Portanto, os OQ que se acumulam na interface ocupando espaço no filme lipídico provavelmente formam ilhas de OQ separadas dos lipídeos, posto que os DPPGs mantêm a conformação bem empacotada (FIGURAS 35 e 36). Visando confirmar este mecanismo molecular de interação, realizamos experimentos de espectroscopia vibracional não linear a uma pressão superficial mais baixa $(\pi=20 \mathrm{mN} / \mathrm{m})$ (FIGURA 36). 
FIGURA 36 - ESPECTROS DE MEMBRANA COM OQ “TIPO-BACTERIANA" - PARTE 1.

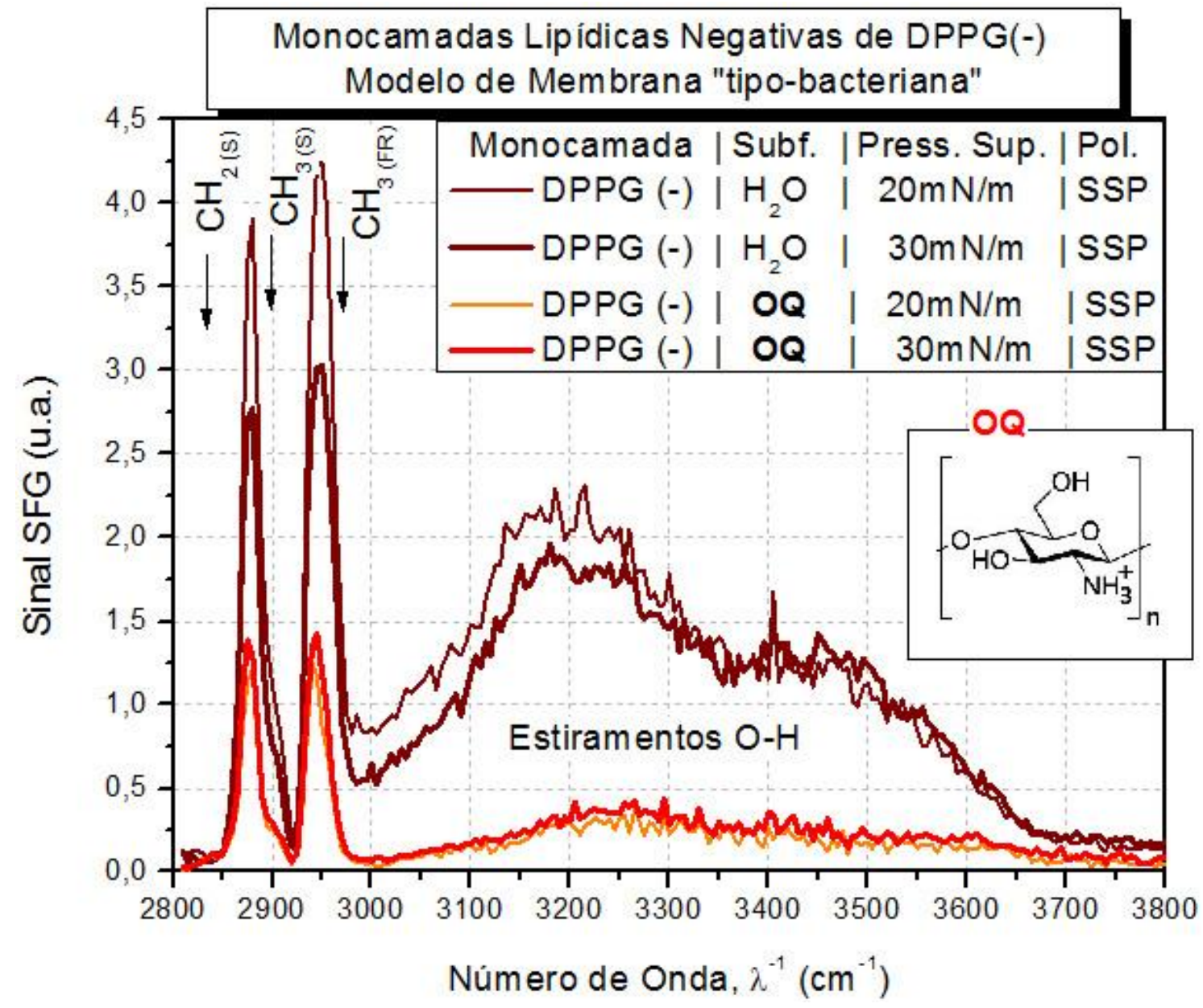

Fonte: Elaborada pelo autor.

Na pressão superficial de $\pi=20 \mathrm{mN} / \mathrm{m}$, o Filme de Langmuir de DPPG(-) tem uma expansão de área média por lipídeo na presença de OQ ainda maior, cerca de $\Delta \sigma \approx 17 \AA^{2} /$ molécula na (c.f. FIGURA 32). Entretanto, o Espectro SFG em $20 \mathrm{mN} / \mathrm{m}$ com OQ na subfase (curva laranja) é igual ao a $30 \mathrm{mN} / \mathrm{m}$ (curva vermelha). Tal resultado reforça nossa hipótese de que os Oligômeros de Quitosana formam ilhas no filme lipídico mantendo o grau de empacotamento deles ( $\mathrm{R}>>1$, conformação all-trans).

Nota: as mudanças nos espectros de controle (água pura) de $20 \mathrm{mN} / \mathrm{m}$ e $30 \mathrm{mN} / \mathrm{m}$ são devidas a uma mudança de hidratação da cabeça polar do lipídeo, como já discutido na literatura.111,115 Brevemente falando, em uma pressão superficial menor, os fosfolipídeos tem mais espaço para mais moléculas de água da interface hidratar as cabeças polares. Consequentemente, há um aumento do sinal SFG dos estiramentos $\mathrm{O}-\mathrm{H}$, que por sua vez causam uma interferência construtiva ainda maior nas vibrações dos grupos alquila dos fosfolipídeos. 
No caso de a subfase aquosa conter o polieletrólito catiônico poli(hidrocloreto de alilamina), PAH, observa-se um aumento da contribuição do sinal de metileno $\left(\mathrm{CH}_{2(\mathrm{~S})}\right)$. Ou seja, há mais lipídeos na conformação gauche na presença de PAH do que a situação controle. Tal resultado sugere que quando o PAH se adsorve na interface contendo DPPG, ele provavelmente causa uma expansão desempacotando os lipídeos (FIGURA 35). Inclusive, este pequeno sinal $\left(\mathrm{CH}_{2(2)}\right)$ é coerente com a pequena expansão observada na FIGURA 32.

Por questão de completeza, foi também feito um espectro em $\pi=20 \mathrm{mN} / \mathrm{m}$ para DPPG em subfase contendo PAH. Como era de se esperar, na FIGURA 37 nenhuma mudança no sinal foi detectada, visto que a expansão devido à presença de PAH em Filmes de DPPG a $30 \mathrm{mN} / \mathrm{m}$ e a $20 \mathrm{mN} / \mathrm{m}$ são praticamente idênticas (FIGURA 32).

FIGURA 37 - ESPECTROS DE MEMBRANA COM PAH “TIPO-BACTERIANA” - PARTE 1.

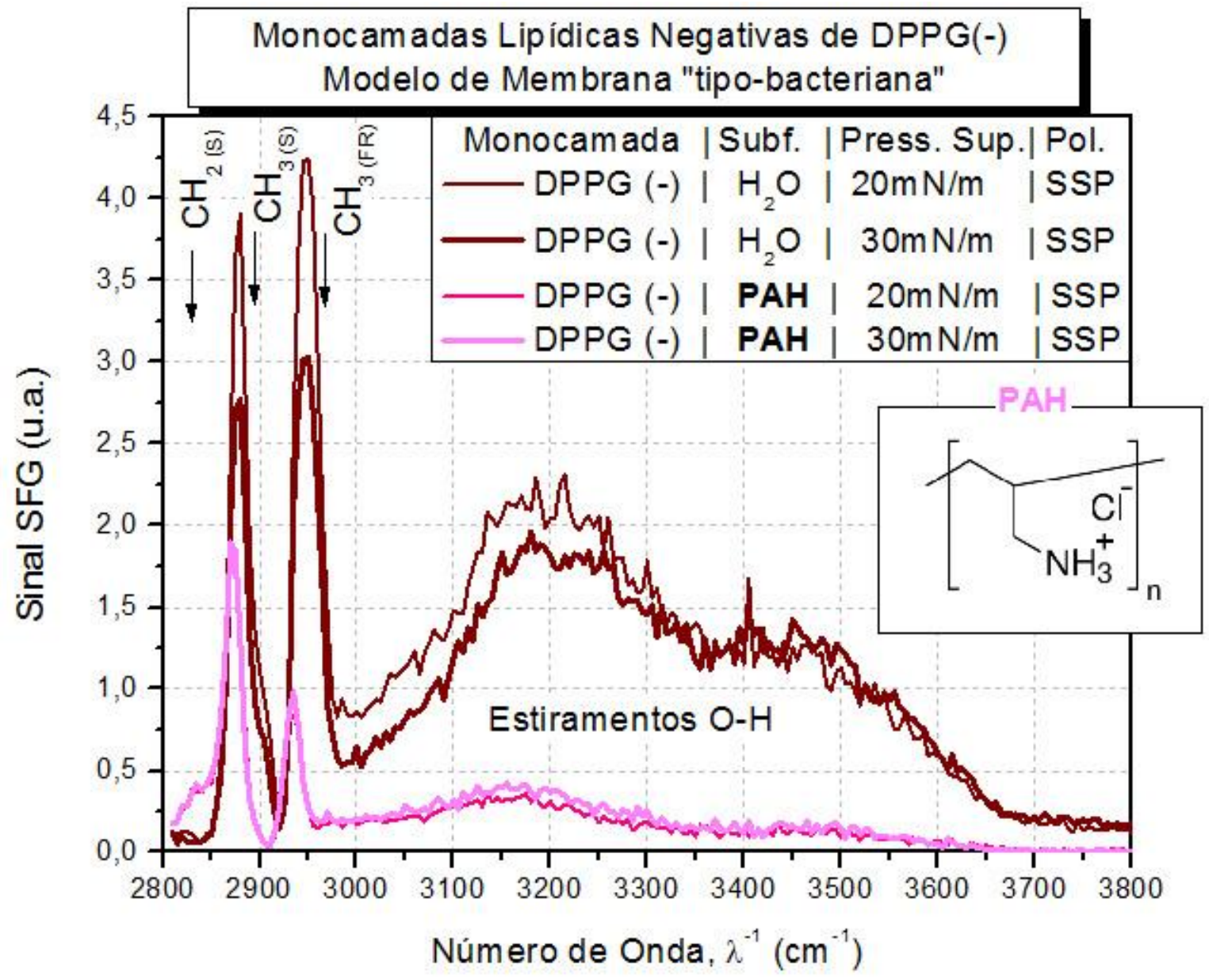

Fonte: Elaborada pelo autor. 
Portanto, o mecanismo de interação molecular dos polieletrólitos com membranas biomiméticas "tipo-bacteriana” de DPPG(-) aparenta ser diferente para PAH e OQ . No caso do PAH, o antimicrobiano tende a se adsorver na interface afastando ligeiramente um lipídeo do outro, o que permite um ligeiro aumento da concentração de defeitos gauche nas cadeias . Já os Oligômeros de Quitosana tendem a se acumular na monocamada lipídica mantendo a compactação lipídica. Tais modos de interação estão resumidos na (FIGURA 38).

FIGURA 38 - MECANISMO DE INTERAÇÃO EM MEMBRANAS TIPO-BACTERIANA. PARTE 1: Analisando empacotamento das caudas lipídicas hidrofóbicas e as mudanças no potencial de membrana ( $\mathrm{H}_{2} \mathrm{O}$ interfaciais).

(a) Membrana Tipo-Bacteriana sobre subfase de $\mathrm{H}_{2} \mathrm{O}$ pura (controle) - Pt 1

\section{DPPG (-)}

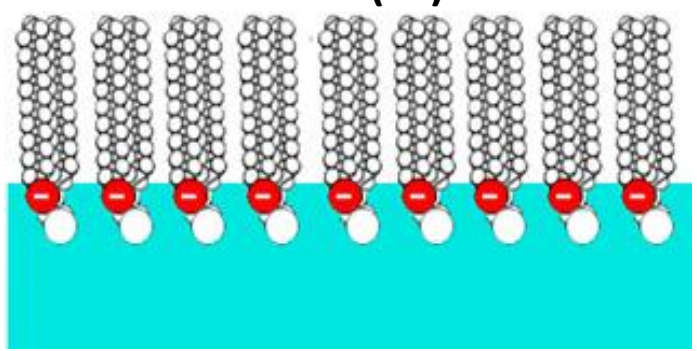

POTENCIAL DE MEMBRANA

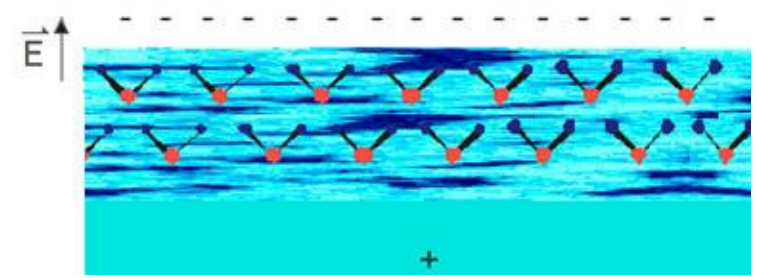

(b) Membrana Tipo-Bacteriana sobre subfase com oligômeros de quitosana (OQ) - Pt 1

\section{DPPG (-)}

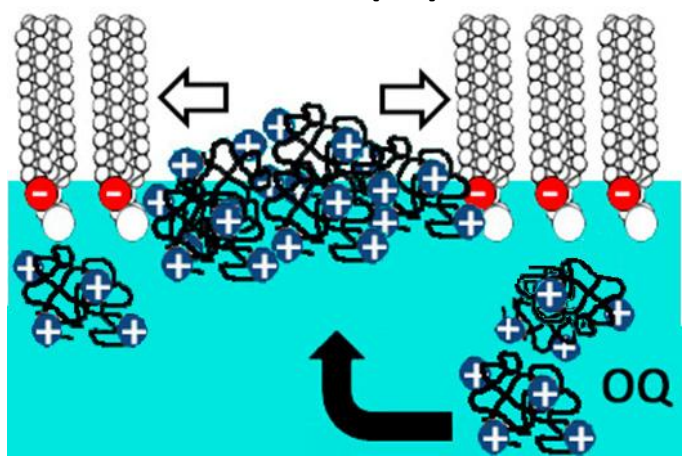

POTENCIAL DE MEMBRANA

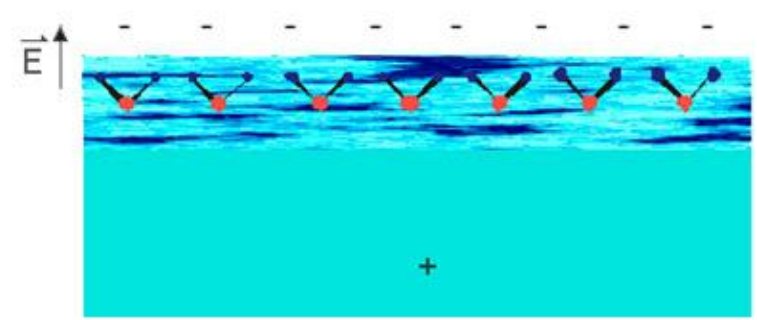

(c) Membrana Tipo-Bacteriana sobre subfase com poli(hidrocloreto de alilamina) (PAH) - Pt 1.

\section{DPPG ( - )}

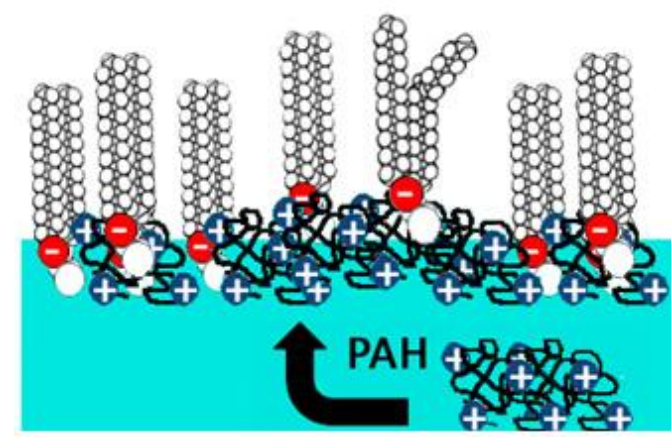

POTENCIAL DE MEMBRANA

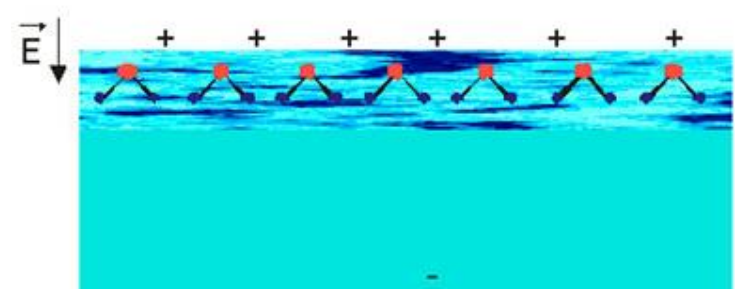

Fonte: Elaborada pelo autor. 


\subsubsection{Espectros SFG das Cabeças Polares dos Fosfolipídeos}

\subsubsection{Interações Moleculares em Membrana “Tipo-Humana”}

Os espectros vibracionais SFG das cabeças polares de DPPC( \pm ) em diferentes polarizações (SSP, SPS e PPP) foram realizados para buscar diferenças nas interações entre OQ e PAH com membranas modelo. Como anteriormente, usamos diferentes subfases $\left(\mathrm{H}_{2} \mathrm{O}=\right.$ controle, solução de $\mathrm{OQ}$ e solução de $\left.\mathrm{PAH}\right)$ durante a compressão isotérmica (Metodologia \#1) até chegar a pressão superficial de interesse $(\pi=30 \mathrm{mN} / \mathrm{m})$. Todos os espectros de cabeça polar foram feitos mantendo esta pressão constante. Nas FIGURAS 39-41 a seguir, apresentamos e discutimos as interações intermoleculares entre os polieletrólitos antimicrobianos e Filmes de Langmuir de DPPC $( \pm)$.

FIGURA 39 - ESPECTROS SFG (SSP) DE MEMBRANA “TIPO-HUMANA” - PARTE 2.

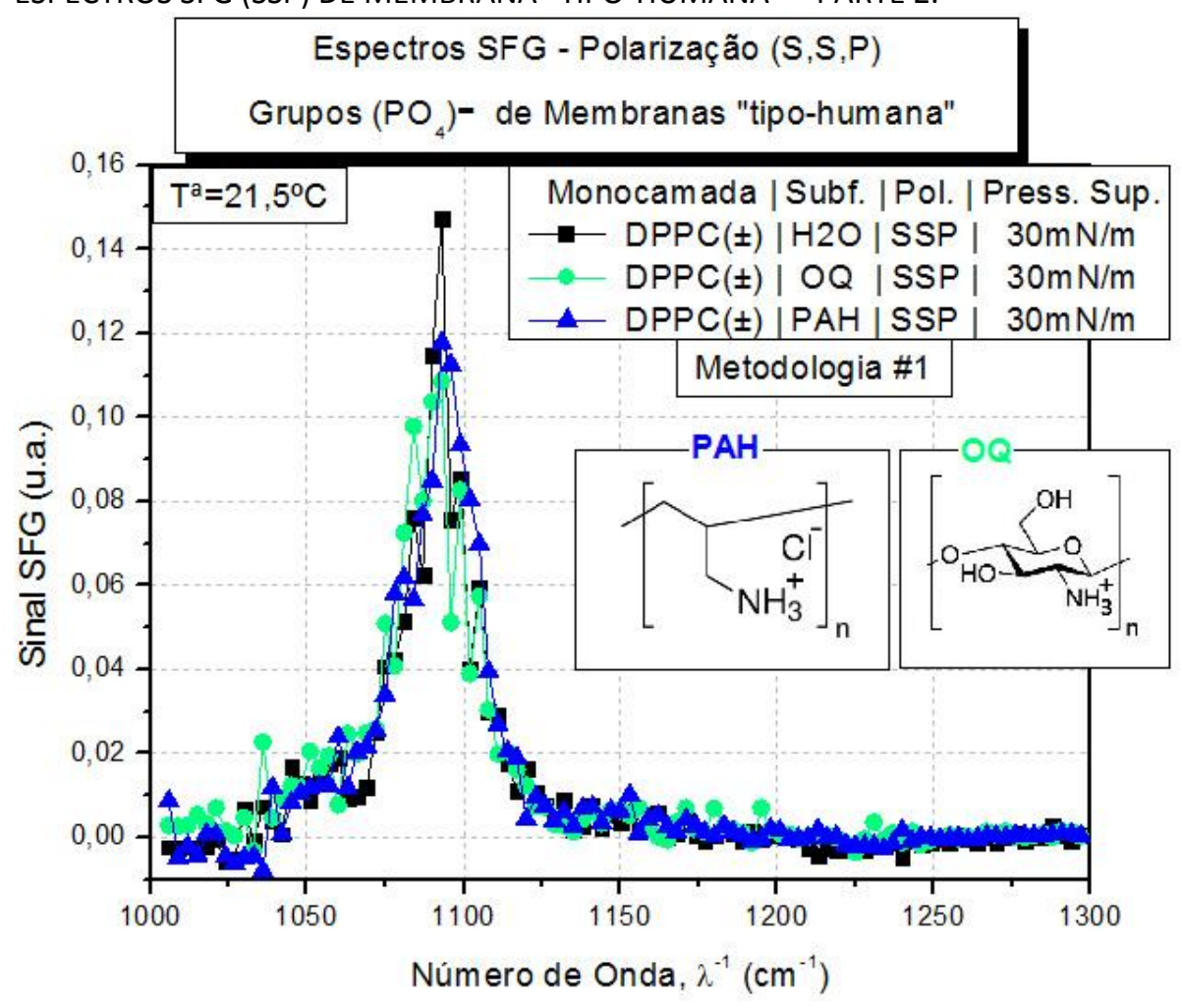

Fonte: Elaborada pelo autor. 
FIGURA 40 - ESPECTROS SFG (SPS) DE MEMBRANA “TIPO-HUMANA" - PARTE 2.

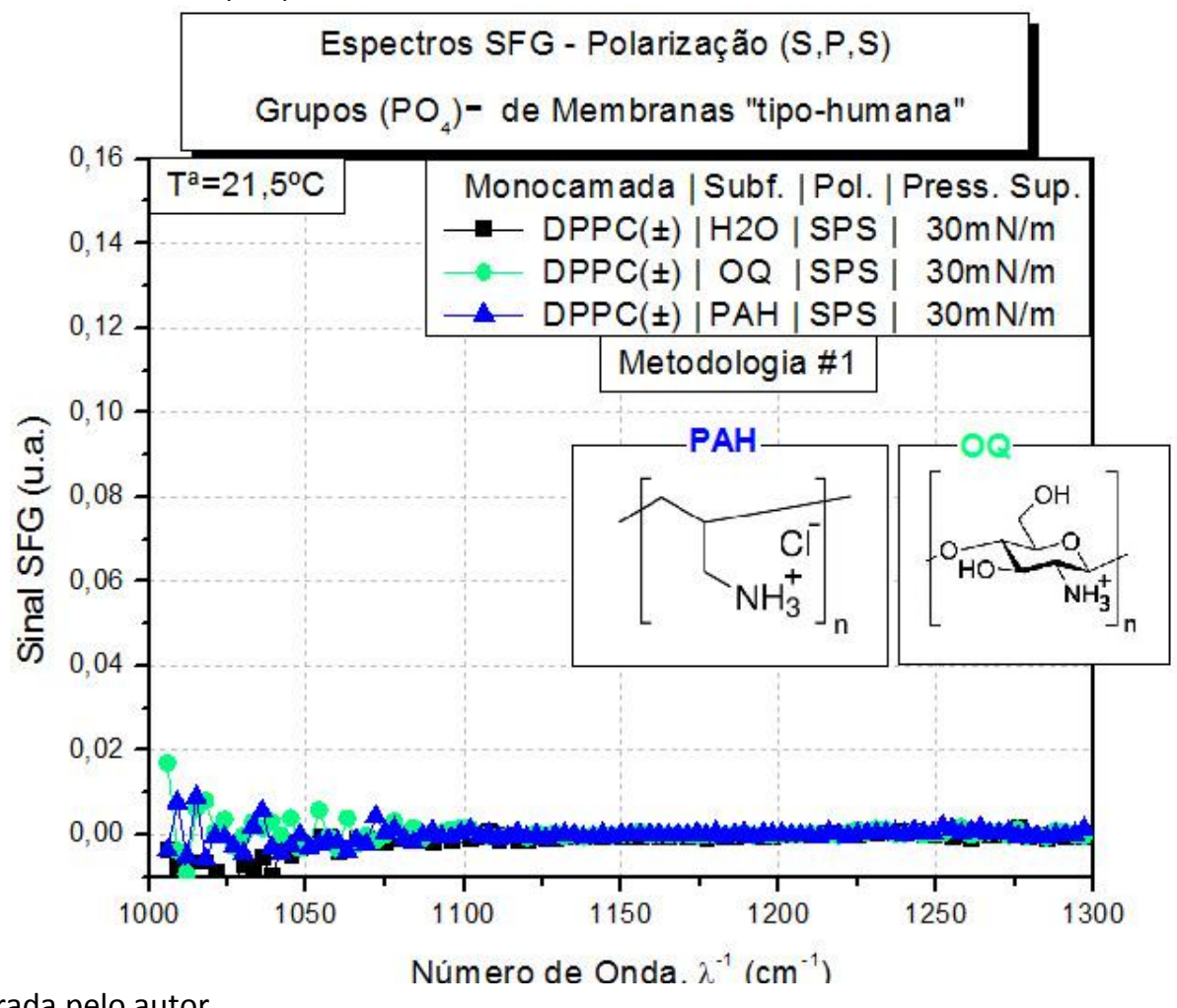

Fonte: Elaborada pelo autor.

FIGURA 41 - ESPECTROS SFG (PPP) DE MEMBRANA “TIPO-HUMANA” - PARTE 2.

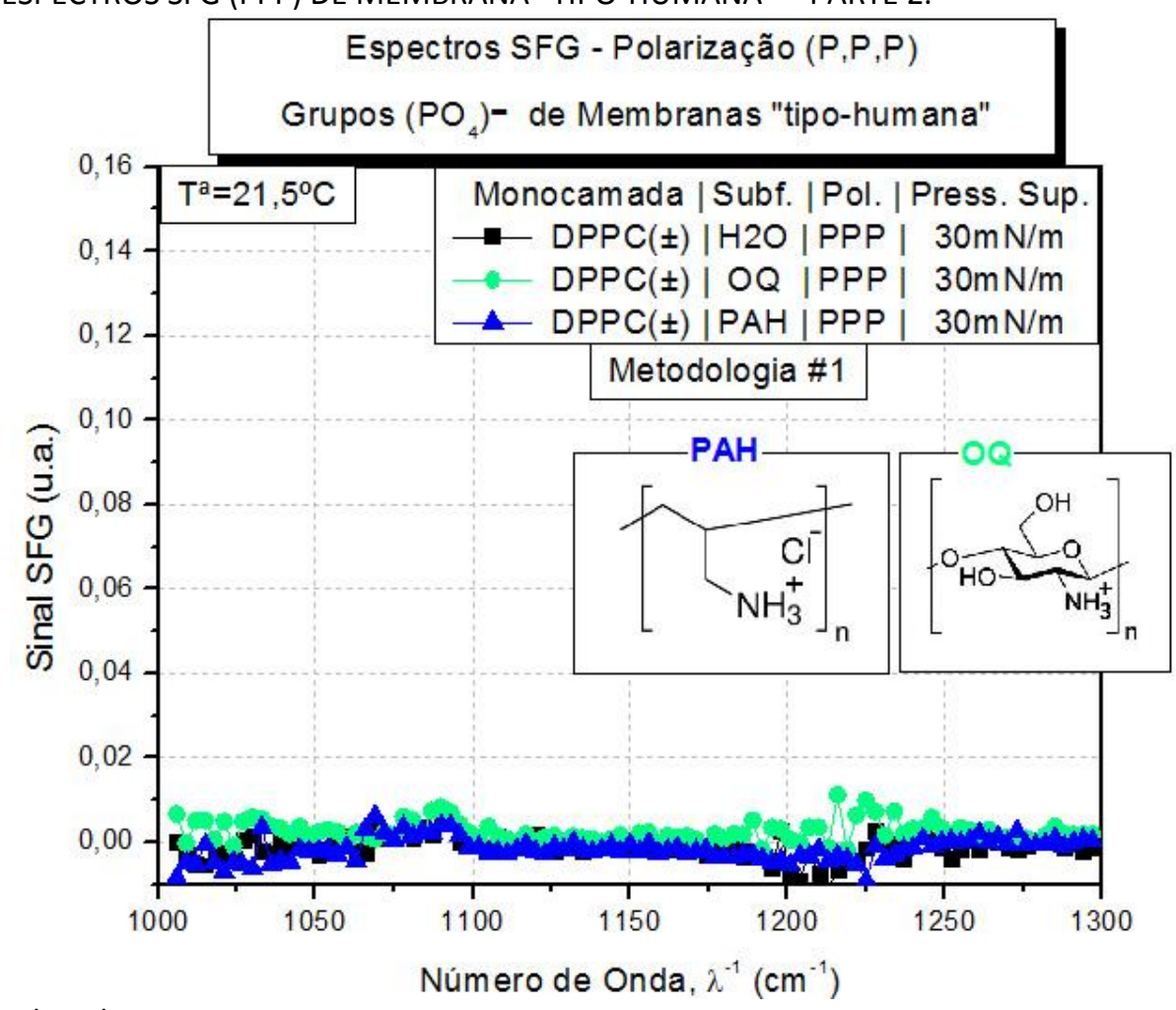

Fonte: Elaborada pelo autor. 
A primeira característica importante de ser notada nos espectros SFG dos grupos fosfato é a magnitude do sinal. A amplitude do maior pico obtido em $\approx 1090 \mathrm{~cm}^{-1}$ (FIGURA 39, curva preta) é cerca de 10 vezes menor que os picos das cadeias alquila das caudas hidrofóbicas de DPPC na mesma combinação de polarizações (S,S,P).

No caso da FIGURA 39, que é o Espectro SFG com a combinação de polarizações convencional $(\mathrm{S}, \mathrm{S}, \mathrm{P})$, vemos um pico em $\approx 1090 \mathrm{~cm}^{-1}$, que é o mais intenso de todos os outros na região espectral da cabeça polar. Como dito anteriormente, esta ressonância é um estiramento simétrico envolvendo 3 átomos do grupo fosfato $\left(\mathrm{PO}_{2}-\right)$. Interessante notar que tanto os Oligômeros de Quitosana, OQ, quanto o poli(hidrocloreto de alilamina), PAH, diminuem um pouco o sinal SFG deste pico. Este resultado sugere que ambos os antimicrobianos perturbam ligeiramente e de modo muito semelhante a cabeça polar de DPPC $( \pm)$, que antes estava mais bem orientada ao longo do eixo-z $(\hat{z}$ perpendicular à interface líquido-ar). Além disso, ainda no mesmo conjunto de polarizações (SSP), há um ombro em $\approx 1050 \mathrm{~cm}^{-1}$. Segundo a literatura, ${ }^{113}$ dois picos próximos que sempre aparece em amostras de fosfolipídeos, um em $1068 \mathrm{~cm}^{-1}$ e outro em $1050 \mathrm{~cm}^{-1}$, estão relacionados a dois estiramentos simétricos envolvendo as duas diferentes ligações 'C-O-P e P-O-C entre os 5 átomos da cabeça polar (R'-O-P-O-R, em que $\mathrm{R}$ e R' são diferentes cadeias carbônicas). Logo, este ombro em $\approx 1050 \mathrm{~cm}^{-1}$ deve ser devido a um destes estiramentos P-O-C da cabeça polar.

Já, nos espectros (SPS e PPP), praticamente não há sinal SFG, exceto por um pequeno pico em $1090 \mathrm{~cm}^{-1}$ devido ao estiramento simétrico do grupo fosfato $\left(\mathrm{PO}_{2}^{-}\right)$na polarização PPP (FIGURA 41). Importante ressaltar que a região espectral próxima de $1000 \mathrm{~cm}^{-1}$ é a mais ruidosa nos nossos experimentos (eventuais valores abaixo de zero são flutuações sem significado físico). Logo, não podemos afirmar na FIGURA 40 se ali tem alguma coisa. Por outro lado, na polarização PPP (FIGURA 41), é curioso existir também uma pequena protuberância bem na região entre $1220 \mathrm{~cm}^{-1}$ e $1225 \mathrm{~cm}^{-1}$, que coincide justamente com os estiramentos antissimétricos do $\mathrm{PO}_{2-}^{-}$, embora seja um sinal muito pequeno e aquela região espectral esteja muito ruidosa. Se não fosse o ruído, isso indicaria uma sutil diferença de tipo de interação dos OQ com $\operatorname{DPPC}( \pm)$ em relação ao PAH. 


\subsubsection{Interações Moleculares em Membrana “Tipo-Bacteriana”}

Analogamente, foram coletados os espectros vibracionais SFG das cabeças polares de DPPG(-). Veja a seguir (FIGURAS 42-44).

FIGURA 42 - ESPECTROS SFG (SSP) DE MEMBRANA “TIPO-BACTERIANA” - PARTE 2.

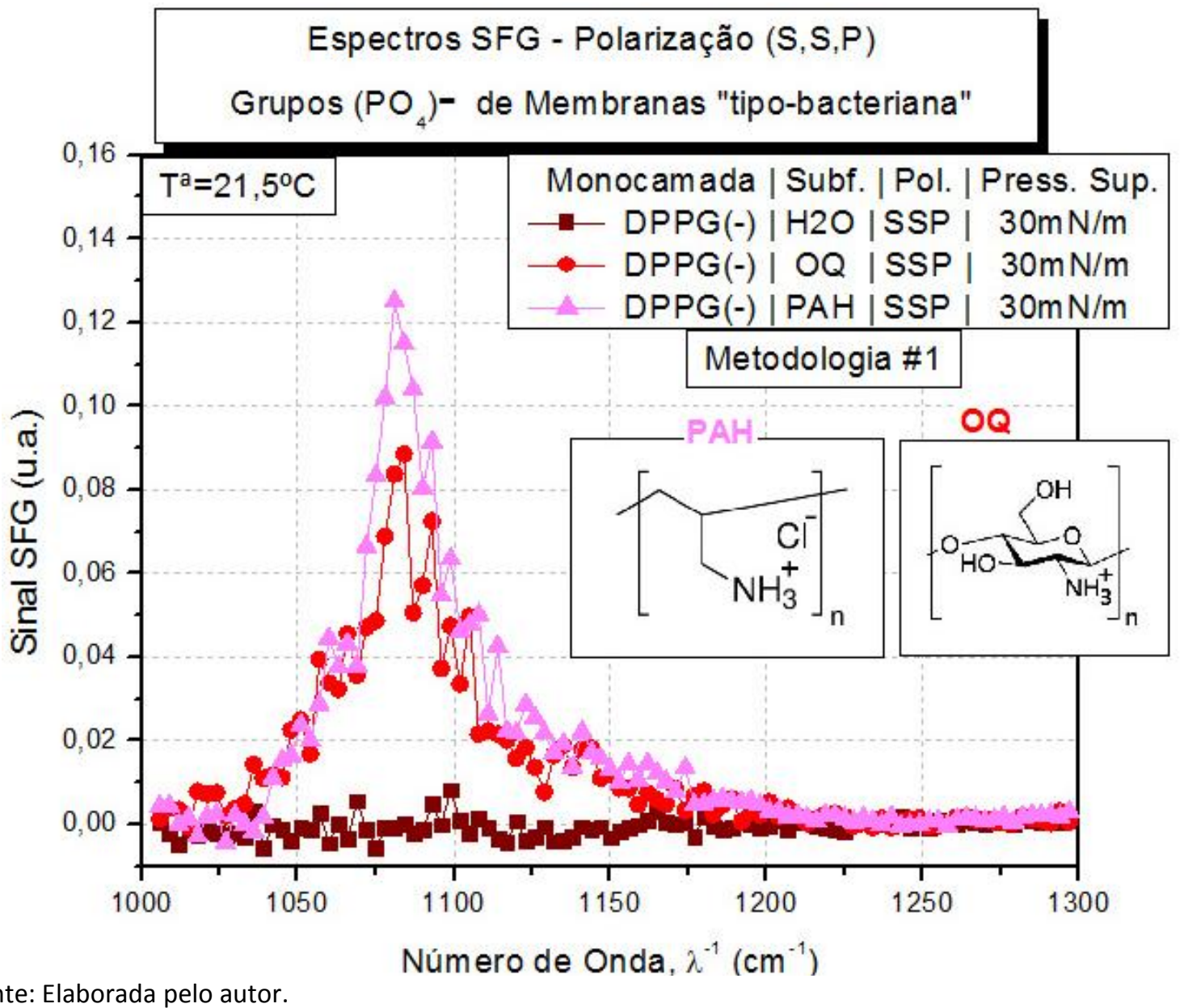

Fonte: Elaborada pelo autor. 
FIGURA 43 - ESPECTROS SFG (SPS) DE MEMBRANA "TIPO-BACTERIANA" - PARTE 2.

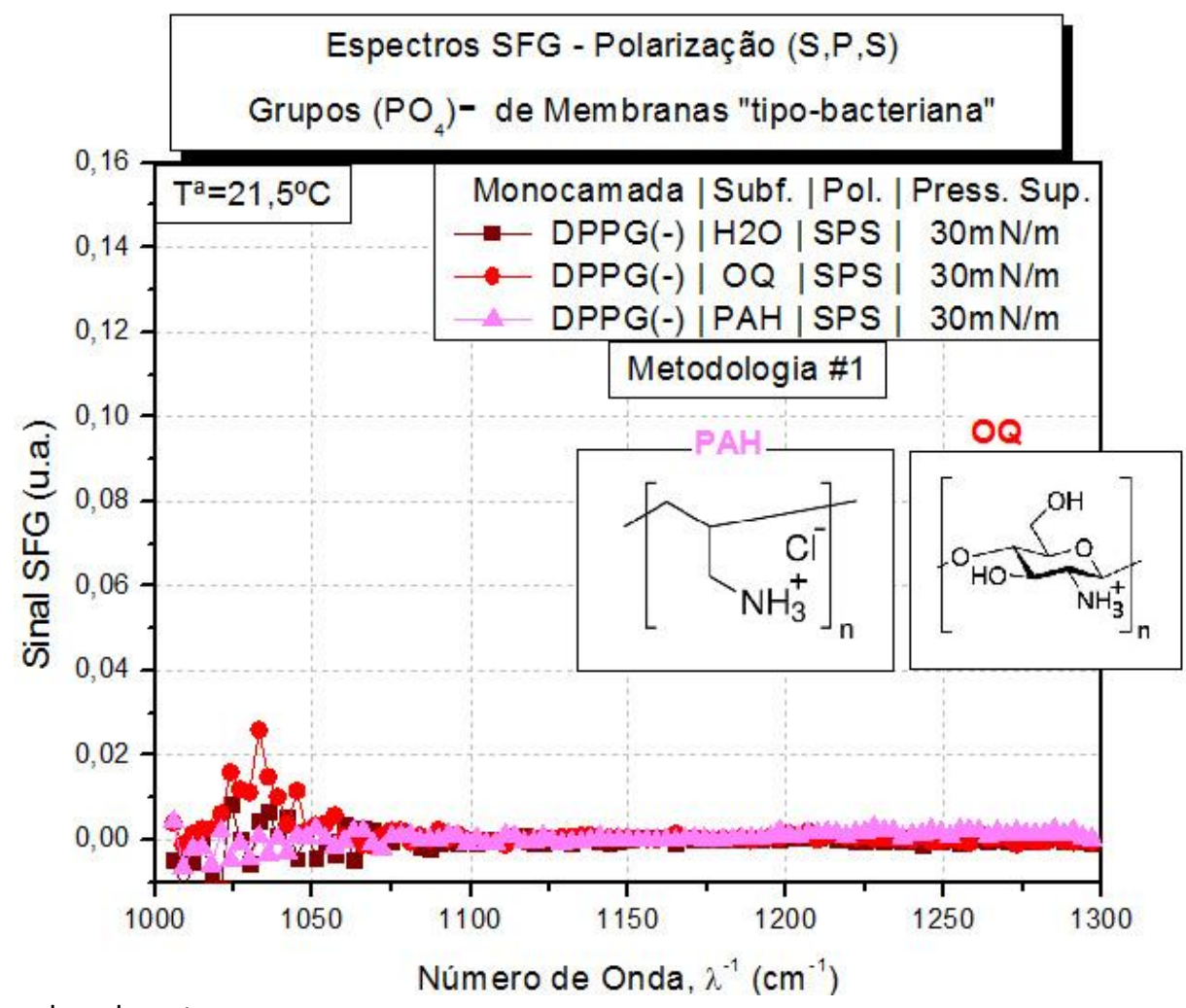

Fonte: Elaborada pelo autor.

FIGURA 44 - ESPECTROS SFG (PPP) DE MEMBRANA “TIPO-BACTERIANA” - PARTE 2.

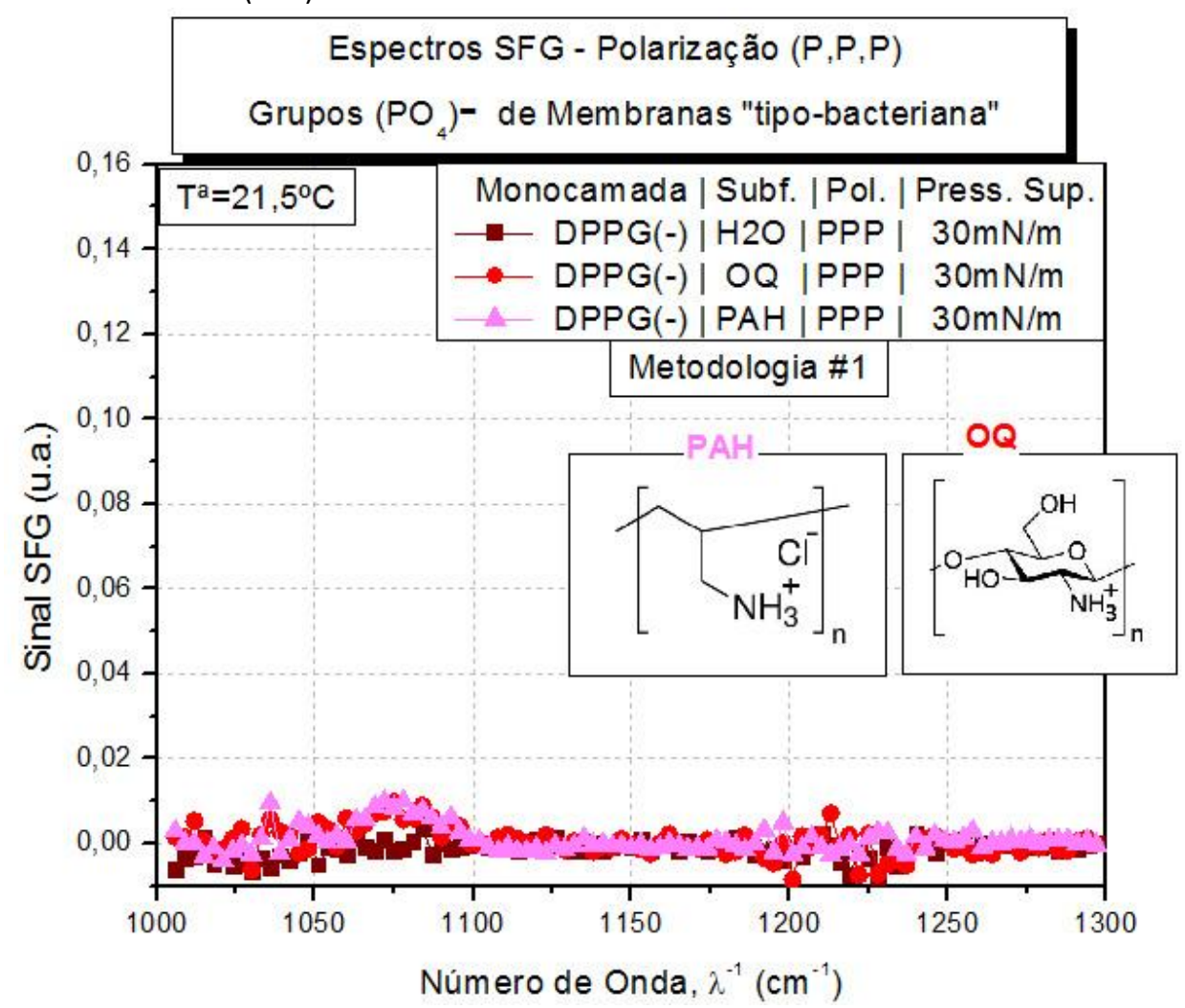

Fonte: Elaborada pelo autor. 
Os resultados dos Espectros SFG de Filmes de Langmuir que mimetizam as biomembranas bacterianas são surpreendentes. 0 primeiro resultado interessante é a respeito do comportamento da cabeça polar do DPPG(-) em água pura (espectro cor de vinho na FIGURA 42. Não há sinal SFG da cabeça polar do DPPG em nenhuma combinação de polarização quando é água pura. Isso significa que, em água pura, os grupos fosfatos dos lipídeos não tem uma orientação preferencial ao longo do eixo-z perpendicular à interface. Tal resultado sugere duas situações: (i) que os grupos fosfato e, consequentemente as cabeças polares do DPPG, estão se movimentando randomicamente na água pura ou (ii) estão situados com o plano do grupo $\mathrm{PO}_{2}^{-}$no plano-xy da interface, de forma isotrópica. Um argumento a favor da hipótese (i) é que há mais espaço disponível na cabeça polar do DPPG do que do DPPC (cujo grupo colina é mais volumoso), de forma que ao ser hidratado é razoável que o grupo fosfato do DPPG tenha uma maior liberdade conformacional.

Por outro lado, o comportamento do filme lipídico diante da presença dos polieletrólitos antimicrobianos altera esse comportamento dinâmico/randômico da cabeça polar dos DPPGs (FIGURAS 42 e 43). Por exemplo, na combinação de polarizações SSP (FIGURA 42), vemos nitidamente um aumento do sinal SFG do estiramento simétrico de $\mathrm{PO}_{2}$ - que ocorrem em $\approx 1080 \mathrm{~cm}^{-1}$ (TABELA 11). Tal aumento é decorrente da quebra de simetria de centro-inversão da movimentação aleatória causado pela presença dos polieletrólitos catiônicos adsorvidos na interface. Uma vez que há OQ (espectro em vermelho) e PAH (espectro em rosa) na interface, ocorre uma reorientação dos grupos fosfato que apontam preferencialmente em direção à subfase contendo os polieletrólitos catiônicos, possibilitando que esse estiramento $\mathrm{PO}_{2}$ - torne-se ativo para a geração de soma de frequências. Em particular, pela (FIGURA 42), notamos que o PAH é um pouco mais eficiente em reorientar os grupos fosfato da cabeça polar ao longo do eixo-z do que os $\mathrm{OQ}$, visto a amplitude deste pico é maior nesta combinação de polarizações SSP.

Curiosamente, na combinação de polarizações SPS (FIGURA 43), vemos que os Oligômeros de Quitosana, OQ interagem com a cabeça polar de DPPGs de maneira diferente dos polieletrólitos de poli(hidrocloreto de alilamina), PAH. Note que a curva em rosa $(\mathrm{PAH})$ é praticamente zero para toda a região espectral, já a curva em vermelho (OQ) tem sinal SFG em $\approx 1033 \mathrm{~cm}^{-1}$. Na literatura, esta região espectral está diretamente 
relacionada à vibrações de polissacarídeos. ${ }^{114,116-118}$ Em particular, como já mostrado na Tabela 14, picos do metileno acetal (O-C-O) ocorrem nas vizinhanças de $1040 \mathrm{~cm}^{-1} .113$ Por outro lado, experimentos de resfriamento de lipossomos multilamelares de DMPG (duas caudas de 14 carbonos saturados com cabeça polar tipo PG) mostraram que uma ressonância de $1035 \mathrm{~cm}^{-1}$ está relacionada à decomposição de duas bandas $\left(1068 \mathrm{~cm}^{-1} \mathrm{e}\right.$ $1090 \mathrm{~cm}^{-1}$ ), que são características de fosfolipídeos na fase líquido-cristalina, em seis outras bandas (1122 cm-1; $1105 \mathrm{~cm}^{-1} ; 1080 \mathrm{~cm}^{-1} ; 1060 \mathrm{~cm}^{-1} ; 1035 \mathrm{~cm}^{-1}$ e $985 \mathrm{~cm}^{-1}$ ) características de fase cristalina. Logo, esta banda vibracional em $1035 \mathrm{~cm}^{-1}$ dos DPPG (duas caudas de 16 carbonos saturados com cabeça polar tipo PG), que só ocorre na presença de oligômeros de quitosana (grande expansão), também sugere que houve uma restrição de movimento drástica da cabeça polar de DPPG (que simula as membranas de bactérias), visto que as vibrações do grupo fosfato desta cabeça polar passam a se comportar como se estivessem na fase sólida (cristalina). Importante ressaltar que este comportamento só aconteceu com o Filme de Langmuir de DPPG(-) na presença de oligômeros de quitosana FIGURA 43). Em nenhum momento isso aconteceu com o Filme de Langmuir de $\operatorname{DPPC}( \pm)$, que simula membranas de humanos (FIGURAS 39-41). Experimentos de espectroscopia SFG de DPPG em água pura a altíssimas pressões superficiais poderiam confirmar se este pico está mais relacionado às ilhas de quitosana no filme de Langmuir do que um possível comportamento das cabeças polares de fosfolipídeos aniônicos em fase cristalina.

Tais resultados estão totalmente coerentes com os mecanismos moleculares de ação que propomos anteriormente, tanto para os Oligômeros de Quitosana quanto para o PAH. Pelo fato de os polieletrólitos terem cargas positivas, ao interagirem com as cabeças polares de DPPG(-), que antes ficavam se movimentando randomicamente na subfase, as cabeças polares sofrem uma reorientação molecular e passam a apontar em média para os polieletrólitos na subfase, gerando sinal SFG. Pelo fato de os OQ ocuparem espaço no filme lipídico sem desempacotar os DPPGs, eles provavelmente se inserem no filme formando ilhas de OQ que empurram os fosfolipídeos na interface, possivelmente, aumentam um pouco o grau de empacotamento lipídico. Por outro lado, o PAH por ter uma cadeia principal menos volumosa do que a dos oligômeros, é capaz de interagir com as cabeças polares dos fosfolipídeos (tanto $\operatorname{DPPC}( \pm)$, quanto $\operatorname{DPPG}(-)$ ), causando uma 
sutil expansão que desempacota um pouco o filme lipídico, o qual continua com certo grau de fluidez, característico da fase líquido-cristalina. .

Esses resultados analisam a interação dos OQ e PAH com os lipídeos durante a formação do filme de Langmuir, visto que os polieletrólitos já se encontram na subfase ao espalhar os fosfolipídeos. Seria interessante (e mais relevante, do ponto de vista da ação antimicrobiana) saber se os Oligômeros de Quitosana são capazes de penetrar em um Filme de Langmuir de DPPG(-) já formado e, em caso afirmativo, se o comportamento dos OQ na monocamada biomimética "tipo-bacteriana" é o mesmo dos resultados até então.

\subsection{DINÂMICAS DE PENETRAÇÃO ISOBÁRICA ( $\sigma$-t)}

\subsubsection{Ensaios de Injeção de Oligômeros de Quitosana}

Visando verificar se os OQ tem capacidade de penetração em membranas tipobacterianas (DPPG), nós fizemos experimentos usando a Metodologia \#2, que consiste em acompanhar no tempo as mudanças que um composto antimicrobiano injetado na subfase causa na área molecular média $(\sigma)$ de um filme lipídico à pressão superficial constante durante a penetração $(\pi=30 \mathrm{mN} / \mathrm{m})$ (FIGURA 45).

FIGURA 45 - DINÂMICA PENETRAÇÃO DE OQ EM MEMBRANA “TIPO BACTERIANA”.

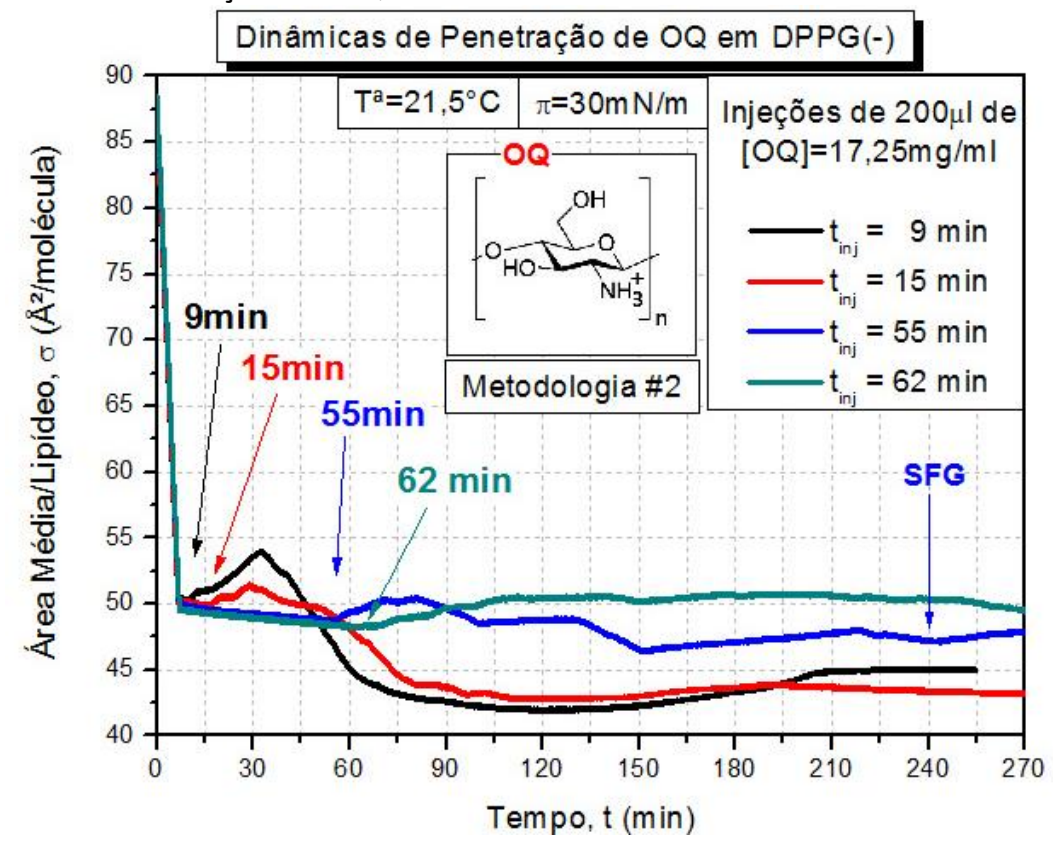

Fonte: Elaborada pelo autor. 
Segundo a FIGURA 45, percebemos que em todos os casos ocorre um aumento da área média disponível por molécula $(\sigma)$ imediatamente após as injeções $(4 \times 50 \mu \mathrm{l} /$ injeção, isto é, $200 \mu \mathrm{l}$ no total injetado de solução [OQ]=17,25mg por experimento). Essas injeções foram realizadas por detrás das barreiras em direção ao centro da cuba, nos tempos $t_{\text {inj }}$ indicados para cada experimento. Observação: nós tivemos o cuidado de verificar se tal aumento de $\sigma$ poderia ser devido à onda de impacto causado pelo ato da injeção. Minutos antes de injetar a solução de quitosana (FIGURA 45), nós injetamos um volume equivalente de água $(200 \mu \mathrm{l})$. Logo, por não haver mudança detectável no comportamento do filme antes de injetarmos $\mathrm{OQ}$, descartamos tais eventuais perturbações devido à onda de impacto durante o ato da injeção.

Embora o filme de DPPG $(30 \mathrm{mN} / \mathrm{m})$ sempre tenha se comportado expandindo (confirmando a penetração de $O Q$ na membrana biomimética) nos momentos iniciais após a injeção de $\mathrm{OQ}$, é bem claro que o comportamento do filme em longo prazo é muito diferente (sobretudo depois dos primeiros 15 minutos subsequentes à injeção). Entretanto, algumas dinâmicas são semelhantes entre si. Por exemplo, as curvas AZUL ( $\left.t_{\text {inj }}=55 \mathrm{~min}\right)$ e VERDE ( $\mathrm{t}_{\text {inj }}=62 \mathrm{~min}$ ) têm um comportamento parecido: a injeção de OQ na subfase sempre causa uma expansão do filme $(\Delta \sigma>0)$ em relação à condição livre de $0 Q$ (curva sem perturbações). Nestes casos, as diferenças no comportamento das dinâmicas são facilmente explicáveis: há uma aleatoriedade da difusão dos compostos antimicrobianos injetados no cerne da subfase até a interface com a membrana modelo. Por mais perfeccionista que o experimentador seja no ato de injetar OQ na subfase, é impossível reproduzir a mesma difusão de $O Q$ da subfase até a monocamada. Consequentemente, diferentes quantias de moléculas de antimicrobiano chegam à interface em tempos diferentes para cada experimento usando essa metodologia. Destarte, a dinâmica de expansão do filme é única para cada experimento. Entretanto, as curvas PRETA ( $\left.\mathrm{t}_{\text {inj }}=9 \mathrm{~min}\right)$ e VERMELHA ( $\left.\mathrm{t}_{\mathrm{inj}}=15 \mathrm{~min}\right)$ apresentam um comportamento em longo prazo completamente diferente das duas curvas anteriores: elas sofrem primeiramente uma expansão (penetração do antimicrobiano no filme) e, em seguida, há uma drástica diminuição de $\sigma$. Em particular, o valor mínimo de área molecular média, cerca de $\Delta \sigma \approx-10 \AA^{2} /$ molécula em relação à extrapolação da curva sem injeção de $0 Q$, ocorre em $\mathrm{t} \sim 120$ min para ambas as curvas (PRETA e VERMELHA). . Então, para esses casos, os OQ não somente estão penetrando na monocamada de DPPG(-) nos 15 minutos 
iniciais, mas também solubilizando a membrana modelo em seguida (trazendo os DPPGs da interface para a subfase depois da penetração). Note que tal solubilização não ocorre nas curvas AZUL e VERDE, que apresentam somente uma dinâmica de expansão do Filme de Langmuir de DPPG(-).

Talvez uma explicação para tal diferença de comportamento no mecanismo de interação dos OQ na monocamada lipídica esteja relacionada ao processo de estabilização do Filme de DPPG. De 0min até $7 \mathrm{~min}$ há o processo de formação da monocamada lipídica (por compressão isotérmica a taxa constante de $10 \mathrm{~mm} / \mathrm{min}$ ), até chegar à pressão de interesse que, em todos os casos, é $\pi=30 \mathrm{mN} / \mathrm{m}\left(\mathrm{t}_{30 \mathrm{mN} / \mathrm{m}}=7 \mathrm{~min}\right)$. Só a partir daí, a cuba mantém esta pressão superficial constante por mecanismo de feedback das barreiras móveis. Considerando esta hipótese, note que as curvas PRETA $\left(\mathrm{t}_{\mathrm{inj}}=9 \mathrm{~min}\right)$ e VERMELHA ( $\left.\mathrm{t}_{\mathrm{inj}}=15 \mathrm{~min}\right)$ ficaram menos tempo mantendo a pressão superficial a $\pi=30 \mathrm{mN} / \mathrm{m}$ (estabilizando o filme), comparado às curvas VERDE( $\mathrm{t}_{\text {inj }}=55 \mathrm{~min}$ ) e AZUL ( $\mathrm{t}_{\text {inj }}$ =62min) (FIGURA 45). Isto é, as curvas VERDE e AZUL descrevem filmes de Langmuir que tiveram um tempo maior para se estabilizarem na interface à pressão $30 \mathrm{mN} / \mathrm{m}$. Tal hipótese também é coerente com o fato de que a curva PRETA (com o menor tempo de estabilização: $t_{\mathrm{inj}}-\mathrm{t}_{30 \mathrm{mN} / \mathrm{m}}=2 \mathrm{~min}$ ) tem uma maior susceptibilidade aos OQ (maiores $|\Delta \sigma(\mathrm{t})|)$ que todas as outras dinâmicas, incluindo em relação à curva vermelha (8min de estabilização). Mais experimentos de injeção devem ser reproduzidos para confirmar esta hipótese.

Uma observação importante nesses experimentos (metodologia \#2) é que, a expansão mais drástica observada (curva preta da FIGURA 45) foi de cerca $\Delta \sigma \approx+4,7 \AA^{2} /$ molécula, que é muito menor do que causada pelos experimentos usando a metodologia \#1 $\left(\Delta \sigma \approx+13 \AA^{2} /\right.$ molécula em $\left.\pi=30 \mathrm{mN} / \mathrm{m}\right)$. Portanto, embora os Oligômeros de Quitosana tenham mostrado que tem capacidade de penetrar em membranas "tipobacterianas", há de fato uma dificuldade extra em causar a expansão desses filmes lipídicos quando há a necessidade de penetrar a barreira lipídica já na fase condensada.

A seguir investigaremos se as interações em nível molecular entre os oligômeros de quitosana e os lipídeos de DPPG (do modelo de membrana "tipo-bacteriana") usando as metodologias \#1 e \#2 são equivalentes. 


\subsection{INVESTIGANDO AS METODOLOGIAS [\#1|\#2] POR ESPECTROSCOPIA SFG}

\subsubsection{Diferenças nas Interações de Oligômeros de Quitosana com Membrana “Tipo-Bacteriana” durante sua: Formação ou Penetração}

Nas FIGURAS 46-48 a seguir, apresentamos diferentes Espectros SFG das interações da cabeça polar de Filmes de Langmuir de DPPG(-) com os oligômeros de quitosana, $\mathrm{OQ}$, frente a duas diferentes situações: metodologia \#1, presença de $O Q$ na subfase durante a formação de monocamada lipídica (compressão isotérmica até $\pi$ de interesse); e metodologia \#2, injeção de OQ na subfase aquosa, causando penetração isobárica (curva AZUL da FIGURA 45) em um Filme de Langmuir já formado em água pura. Em ambos os casos, manteve-se a pressão superficial biologicamente relevante $(\pi=30 \mathrm{mN} / \mathrm{m})$ constante durante a aquisição de espectro.

FIGURA 46 - COMPARANDO METODOLOGIAS - ESPECTROS SFG EM ÁGUA PURA.

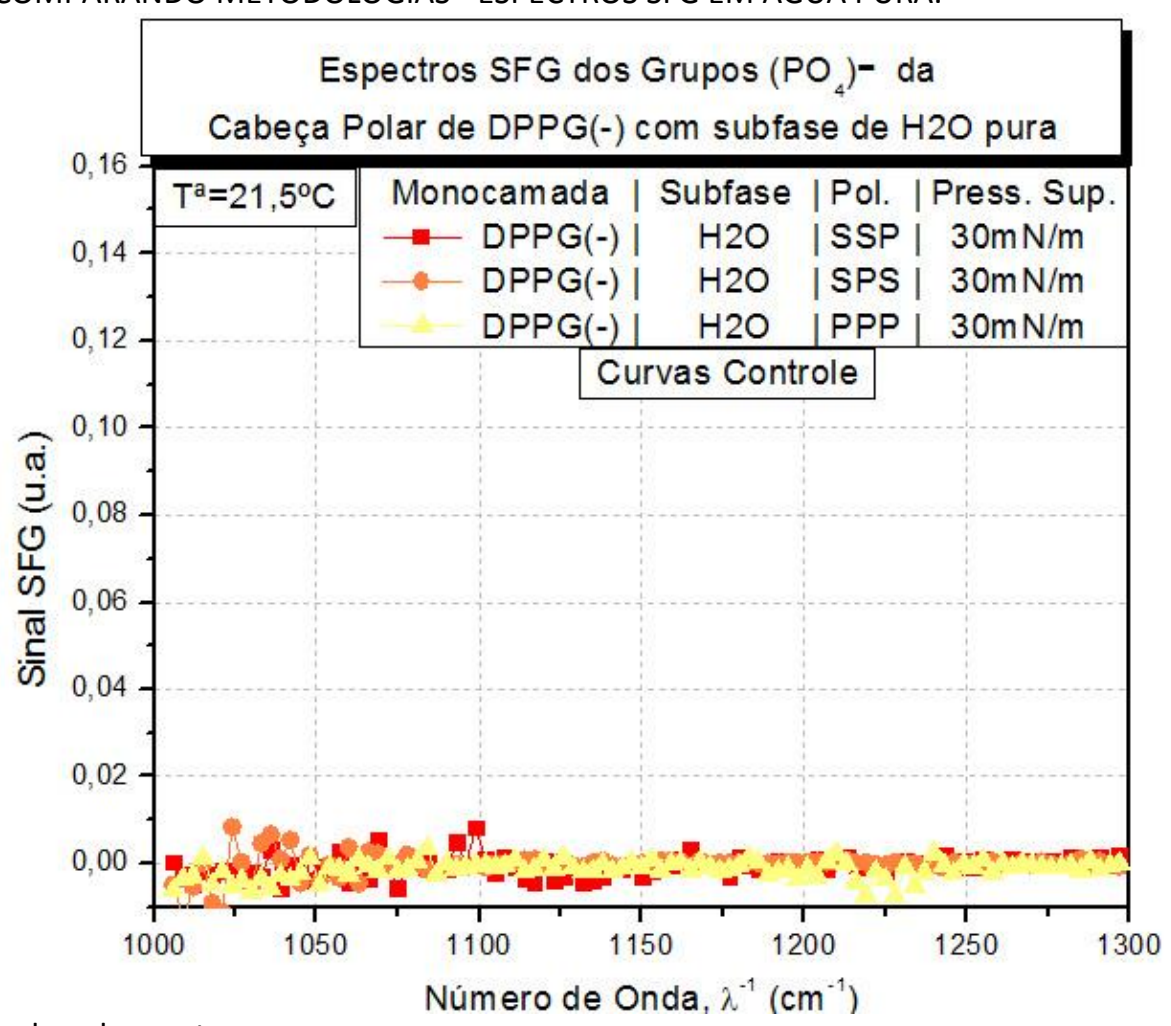

Fonte: Elaborada pelo o autor. 
FIGURA 47 - COMPARANDO METODOLOGIAS - METODOLOGIA \#1 - DPPG-OQ

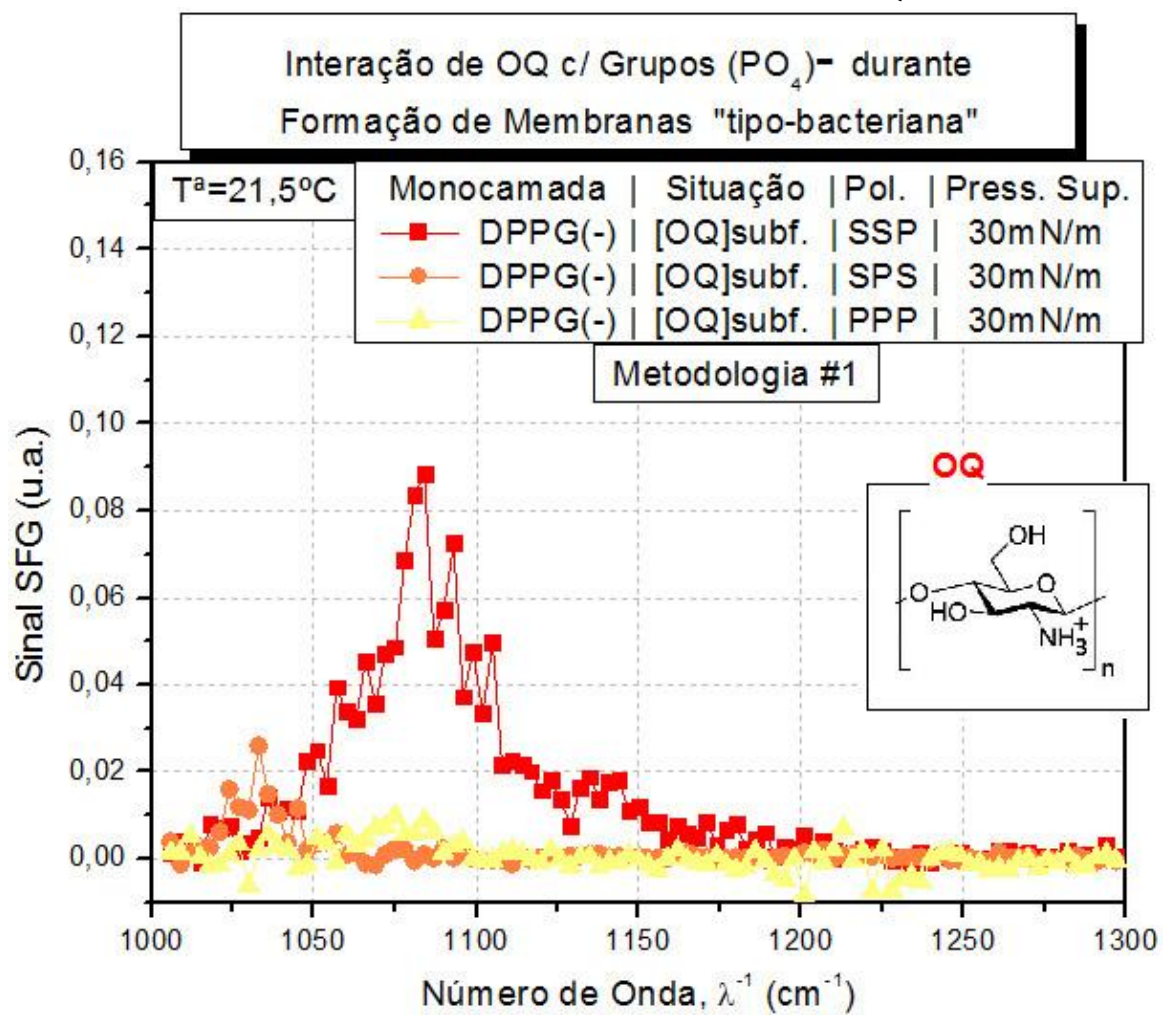

Fonte: Elaborada pelo o autor

FIGURA 48 - COMPARANDO METODOLOGIAS - METODOLOGIA \#2 - DPPG-OQ

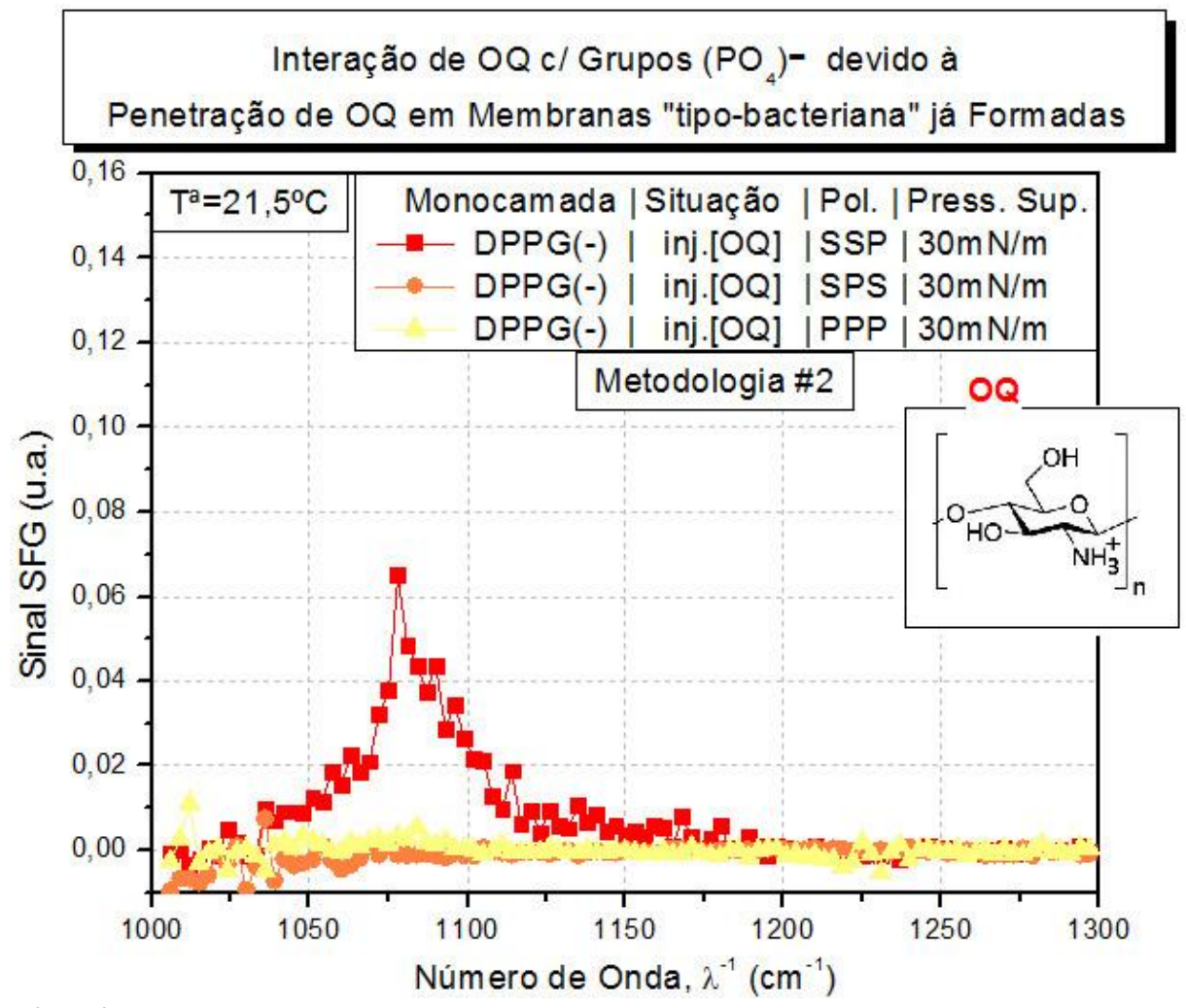

Fonte: Elaborada pelo autor 
Comparando os espectros SFG em vermelho (combinação SSP), vemos que o pico em $\approx 1080 \mathrm{~cm}^{-1}$ só aparece na presença de OQ, independentemente da metodologia. Entretanto, a interação de $O Q$ adsorvido na interface durante a formação do Filme de Langmuir de DPPG (metodologia \#1) é mais intensa do que a pela metodologia \#2. Provavelmente, esta diferença de magnitude do sinal está relacionada à quantidade de OQ que realmente está entre os fosfolipídeos e adsorvida entre as cabeças polares. As ilhas de $\mathrm{OQ}$ presentes na interface pela metodologia \#1 causaram uma expansão do filme lipídico muito grande, cerca de $\Delta \sigma \approx 13 \AA^{2} /$ molécula (FIGURA 32). Já as ilhas de OQ causadas pela metodologia \#2, devido à penetração de $0 Q$ no filme lipídico a $30 \mathrm{mN} / \mathrm{m}$ é de cerca de $\Delta \sigma \approx 3 \AA^{2} /$ molécula (curva azul na FIGURA 45).

Essa diferença na expansão do filme lipídico também justifica o porquê que na combinação SPS da metodologia por injeção (curva laranja da FIGURA 48) não aparece o pico em $\approx 1033 \mathrm{~cm}^{-1}$. Como houve pouca expansão, há poucas ilhas de quitosana no filme gerando sinal do estiramento do metileno acetal (O-C-O). Por outro lado, se este pico estiver relacionado ao estiramento do $\mathrm{PO}_{2}$ - em membranas lipídicas em fase cristalina, é possível que pequenas as ilhas de OQ formadas não tenham aumentado tanto o grau de empacotando dos lipídeos a ponto de as cabeças polares vibrarem de forma equivalente à fase cristalina (curva laranja da FIGURA 47). Note que as curvas em vermelho (polarização SSP) sugerem a existência de múltiplos picos na FIGURA 47, que não acontece na FIGURA 48. Portanto, se acreditarmos nesta segunda interpretação, o modo de interação ainda é semelhante, mas as cabeças polares dos DPPG, ao invés de se compactarem em uma fase cristalina, vibram em um ambiente tipicamente de filmes líquido-cristalinos na metodologia \#2. Independentemente da assinatura do pico $1033 \mathrm{~cm}^{-1}$, as mudanças espectrais parecem refletir a pouca expansão/penetração do filme lipídico devido à presença dos oligômeros de quitosana.

Portanto, há diferenças na capacidade de interação de antimicrobianos com filmes lipídicos usando a metodologia \#1 (influência de antimicrobianos na subfase enquanto se cria uma monocamada lipídica) e a metodologia \#2 (penetração de um antimicrobiano em uma monocamada já formada). Os oligômeros de quitosana se mostraram menos eficientes na perturbação da monocamada de DPPG quando o filme lipídico já estava formado. Vale a pena ressaltar que a interação de sais ou biomoléculas na subfase com filmes de Langmuir é, em geral, investigada na literatura utilizando a 
metodologia 1 ou a metodologia 2, mas estudos comparativos não são de nosso conhecimento. Portanto, essa diferença observada nos resultados em função da metodologia utilizada é muito relevante para guiar trabalhos futuros que utilizem filmes de Langmuir como modelos de membrana. Para resumir todas as informações que coletamos (incluindo agora as da cabeça polar), ilustramos os dois diferentes mecanismos de interação molecular dos OQ e PAH nas diferentes membranas modelo (DPPC( \pm ), “tipo-humana” e DPPG(-), "tipo bacteriana”) nas FIGURAS 49-50:

FIGURA 49 - MECANISMOS DE INTERAÇÃO DE POLIELETRÓLITOS COM MEMBRANAS “TIPO-HUMANA”.

(a) Membrana Tipo-Humana sobre subfase de $\mathrm{H} 2 \mathrm{O}$ pura (controle) - Pt 1 e 2.

$\operatorname{DPPC}( \pm)$

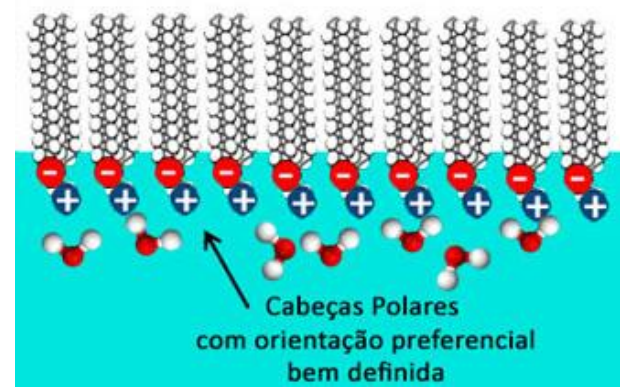

POTENCIAL DE MEMBRANA

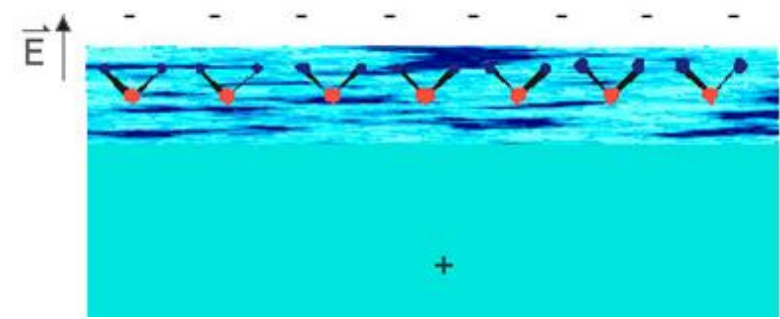

(b) Membrana Tipo-Humana sobre subfase de solução de oligômeros de quitosana (OQ) - Pt 1 e 2.

\section{$\operatorname{DPPC}( \pm)$}

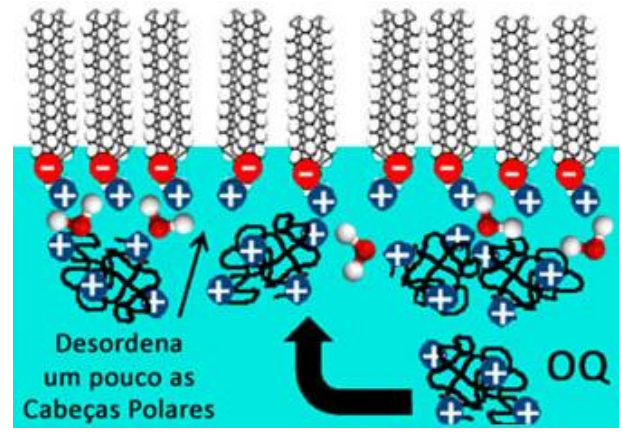

POTENCIAL DE MEMBRANA

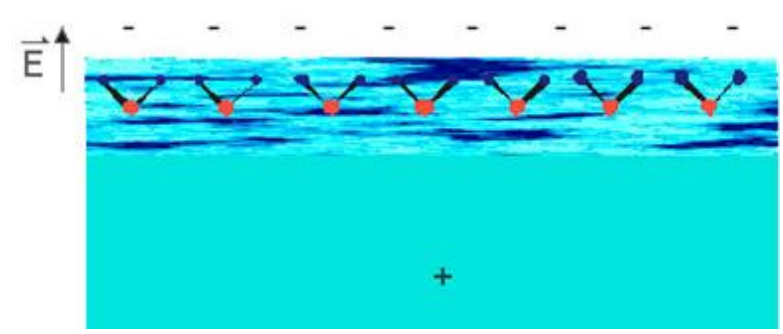

(c) Membrana Tipo-Humana sobre subfase de solução de poli(hidrocloreto de alilamina)(PAH) - Pt 1 e 2.

\section{$\operatorname{DPPC}( \pm)$}

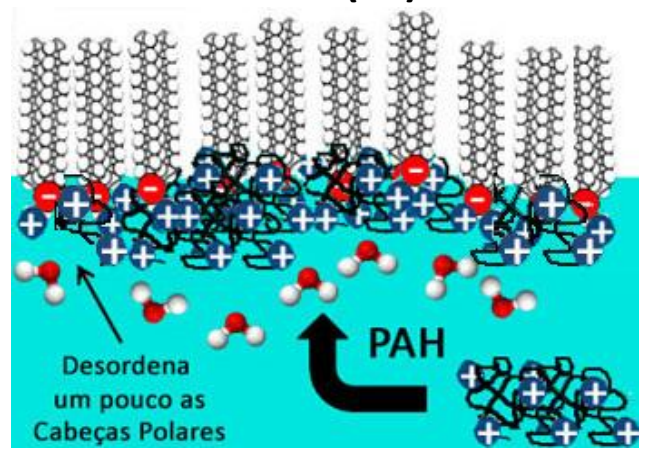

POTENCIAL DE MEMBRANA

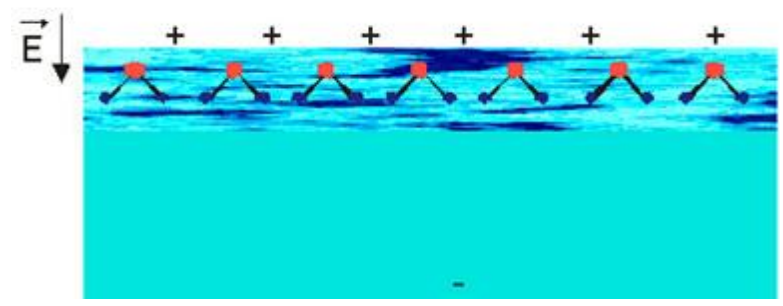

Fonte: Elaborada pelo autor. 
FIGURA 50 - MECANISMOS DE INTERAÇÃO DE POLIELETRÓLITOS COM MEMBRANAS “TIPO-BACTERIANA”.

(a) Membrana Tipo-Bacteriana sobre subfase de $\mathrm{H}_{2} \mathrm{O}$ pura (controle) - Pt 1 e 2.

\section{DPPG ( - )}

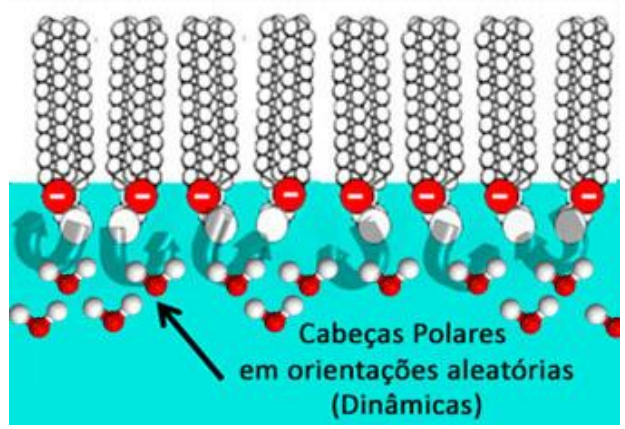

POTENCIAL DE MEMBRANA

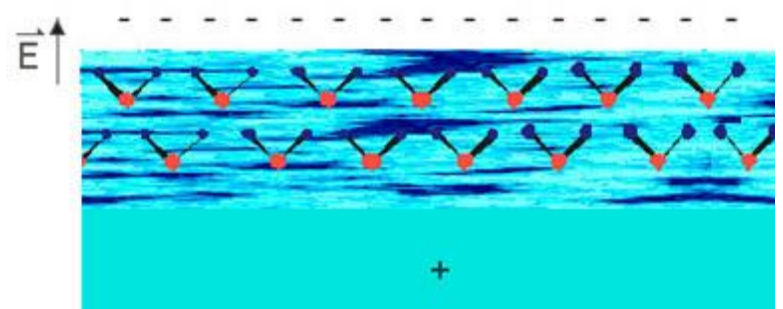

(b) Membrana Tipo-Bacteriana sobre subfase com oligômeros de quitosana (OQ) - Pt 1 e 2

DPPG (-)

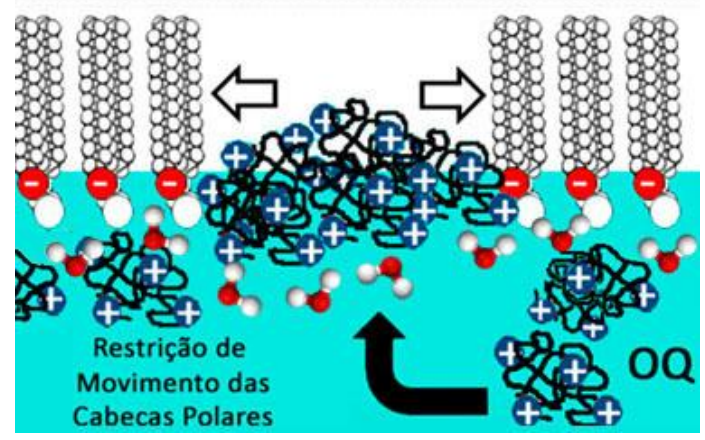

POTENCIAL DE MEMBRANA

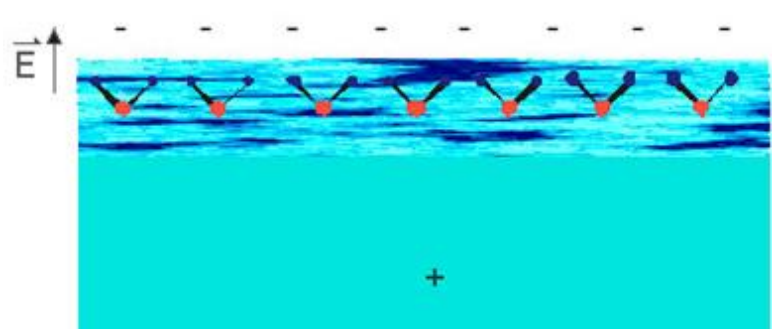

(c) Membrana Tipo-Bacteriana sobre subfase com poli(hidrocloreto de alilamina) (PAH) - Pt 1. e 2

\section{DPPG ( - )}

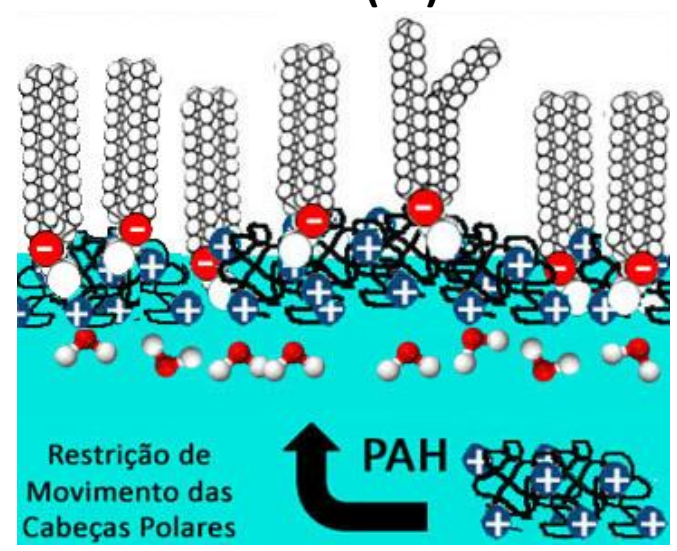

3

Fonte: Elaborada pelo autor.
POTENCIAL DE MEMBRANA

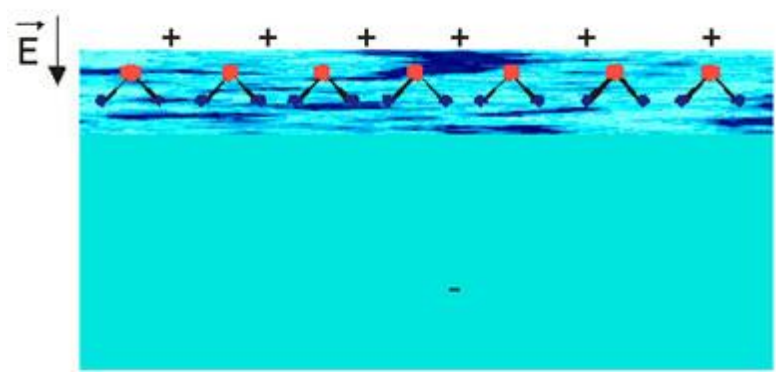




\section{DISCUSSÕES}

Nossos estudos de termodinâmica de superfície, que medem a interação de compostos solubilizados na subfase aquosa durante a compactação lipídica (formação da monocamada modelo, metodologia \#1), estão coerentes com a literatura:[29, 60,109] o PAH interage com ambos os modelos de membrana ("tipo-humana" e "tipo-bacteriana"). Já os oligômeros de quitosana, que são mais seletivos, causam uma expansão drástica somente nas membranas biomiméticas bacterianas. Vale ressaltar que a investigação das interações biomoleculares de oligômeros de quitosana (tamanhos entre $1.000 \mathrm{~g} / \mathrm{mol}$ e $10.000 \mathrm{~g} / \mathrm{mol}$ ) em filmes de Langmuir de DPPC e DPPG em água pura (pH 5 ,7) por análise de termodinâmica e por espectroscopia vibracional não tinha sido feita anteriormente na literatura. Portanto, os resultados aqui apresentados são inéditos.

A análise molecular desses sistemas, a uma pressão superficial de relevância biológica $(\pi=30 \mathrm{mN} / \mathrm{m})$ foi feita usando a Espectroscopia Vibracional Não Linear por Geração de Soma de Frequências - a Espectroscopia SFG. Esta técnica é sensível a vibrações moleculares de materiais em ambientes sem simetria de inversão. Por esta razão, os espectros vibracionais das poucas moléculas que constituem os Filmes de Langmuir na interface líquido-ar são detectados e estão livres dos sinais das moléculas do cerne do meio líquido. Além disso, a intensidade do sinal depende da orientação média das moléculas na interface, e o espectro SFG dos estiramentos $\mathrm{CH}$ de cadeias lipídicas é muito sensível à sua conformação molecular (defeitos gauche).

Ao analisarmos os espectros vibracionais da interação entre os fosfolipídeos de DPPC $( \pm)$ ou de DPPG(-) com os polieletrólitos antimicrobianos (OQ ou PAH) que estavam na subfase durante a formação da monocamada(metodologia \#1), nossos resultados sugerem que o PAH e $\mathrm{OQ}$ têm um mecanismo de interação molecular diferente nesses modelos de membrana (FIGURAS 49 e 50).

O PAH, polímero sintético não biocompatível com células humanas, causa uma pequena expansão (perturbação) homogênea (FIGURAS 31-35) em ambos os modelos de membrana (FIGURAS 49.c e 50.c). Tal expansão tende a desempacotar os lipídeos (aumenta o espaço entre eles), sobretudo nos filmes de DPPG(-) (FIGURAS 50.c), nos quais visivelmente houve um aumento na população de fosfolipídeos na conformação gauche em detrimento da conformação all-trans (FIGURA 35). Acreditamos que para a 
ocorrência disto, a cadeia principal do PAH, por ser pouco volumosa, menos hidrofóbica, mais carregada e provavelmente mais estendida, tenha a tendência de interagir mais com as cabeças polares dos fosfolipídeos, entrelaçando-se entre elas (FIGURAS 49.c e 50.c). Inclusive, os grupos fosfato da cabeça polar dos DPPGs sofreram uma restrição de movimento, reduzindo as possíveis orientações moleculares na interface sob a presença de PAH, visto que desta forma passou a gerar sinal SFG (FIGURAS 42-44). Em água pura, a cabeça polar dos DPPGs(-) não geravam sinal SFG, posto que ficavam randomicamente distribuídas no líquido (FIGURAS 42-44). Por outro lado, as cabeças polares de DPPC( \pm ), que já têm uma orientação preferencial ao longo do eixo-z (perpendicular à interface) (FIGURAS 39-41, 49.a), já geram sinal em água pura (FIGURAS 39-41). Quando interagindo com $\mathrm{PAH}$, as cabeças polares de $\mathrm{DPPC}( \pm)$ possivelmente ficam um pouco mais desordenadas, pois há uma ligeira queda no sinal SFGi evidenciando novamente uma interação do polieletrólito com os grupos polares do lipídeo. (FIGURAS 39-41). Tal modo de ação se assemelha ao do modelo tipo carpete dos AMPs (FIGURA 05.f).

Tal hipótese também é coerente com o comportamento das moléculas de água interfaciais na presença de PAH, que apontam em direção oposta ao longo do eixo-z em relação à situação com água pura. A orientação molecular dos dipolos da água dá uma informação indireta do potencial de membrana. Neste sentido, o PAH é um polieletrólito catiônico que foi capaz de se adsorver nas duas membranas (de DPPC, "tipo-humana", e de DPPG, "tipo-bacteriana”) causando uma supercompensação de cargas nas interfaces. (FIGURAS 49.c e 50.c) Este fato provavelmente se deve ao seu tamanho ( $\approx 10 \mathrm{x}$ maior que os $0 Q$ ), que comporta uma quantidade de carga maior em sua cadeia $(\approx 10 \mathrm{x}$ maior que os OQ também). Assim, quando 1 molécula de PAH se adere ao filme lipídico, ela carrega 10x mais carga para a interface que a adesão de 1 molécula de OQ. Estes, por sua vez, tem um comportamento mais semelhante ao de íons inorgânicos monovalentes, que são incapazes de inverter o potencial de membrana devido à saturação de cargas na interface.

Como o PAH é um polieletrólito com pouquíssimo caráter hidrofóbico, acreditamos que as eventuais interações hidrofóbicas com as cadeias alifáticas dos fosfolipídeos causam uma perturbação muito sutil nas membranas. Mesmo se considerarmos a pequena perturbação que o PAH causou nas isotermas de $\operatorname{DPPC}( \pm)$ (FIGURA 31) como totalmente devido às interações hidrofóbicas com a caudas apolares, 
então tal interação seria praticamente desprezível comparada à magnitude das interações do PAH com os DPPGs(-). Logo, seria razoável considerar que as eventuais mudanças no espectro na região de estiramentos $\mathrm{C}-\mathrm{H}$ sejam consequências exclusivamente do aumento da área entre lipídeos na interface (devido à presença do PAH entre as cabeças polares) e à mudança da organização da água interfacial (devido ao excesso de cargas positivas que o PAH trouxe à interface). Logo, as interações moleculares predominantes envolvidas seriam: interações eletrostáticas e ligações de hidrogênio - embora não tenhamos evidência direta desse tipo de interação, visto que não há sinal SFG do PAH e os grupos fosfatos estão sempre ligados à água e/ou PAH.

Já os oligômeros de quitosana (OQ) interagem com as monocamadas lipídicas de DPPC( \pm ) e DPPG(-) de um modo totalmente diferente que o PAH (FIGURAS 49.b e 50.b). A primeira característica importante é que os $0 Q$ são de fato bem mais seletivos que o PAH. Esta seletividade é observada tanto nos experimentos de termodinâmica de superfície (FIGURAS 31-32), quanto nos espectros SFG que coletamos (FIGURAS 33-35). Como a grande diferença de estrutura química entre os lipídeos de DPPC( \pm ) e DPPG(-) é justamente o caráter iônico das cabeças polares, talvez a primeira etapa de interação, eletrostática, seja de fato suficiente para determinar a seletividade e, consequentemente, a biocompatibilidade com células humanas. Os oligômeros de quitosana na subfase aquosa não alteram significativamente a interação entre as caudas dos fosfolipídeos zwitteriônicos (DPPC, "Tipo-Humana") durante o processo de compressão isotérmica (diagrama $\pi-\sigma$, FIGURA 31), visto que a forma de linha da isoterma é a mesma e os espectros dos grupos alquila são muito semelhantes em relação ao controle $\left(\mathrm{H}_{2} \mathrm{O}\right)$ (FIGURA 33). Entretanto, há uma ligeira expansão do filme de $\operatorname{DPPC}( \pm)$, sugerindo que OQ estejam adsorvidos na interface, provavelmente interagindo eletrostaticamente com as cabeças polares como visto anteriormente em trabalhos do nosso grupo em pH mais ácidos, ${ }^{57-58}$ pois há uma sutil queda nos espectros das cabeças polares de DPPC (FIGURA 39 e 49.b). Além disso, o espectro vibracional de monocamadas de $\operatorname{DPPC}( \pm)$ na região dos estiramentos $\mathrm{O}-\mathrm{H}$ da água é idêntico com ou sem quitosanas (FIGURA 33). Isto é um indicativo de que a quantidade de quitosanas adsorvidas no filme de $\operatorname{DPPC}( \pm)$ não é suficiente para alterar significativamente o potencial de membrana. No entanto, as cabeças polares destes fosfolipídeos realmente devem sentir um ambiente químico diferente na presença dos oligômeros. Tal fato pode estar relacionado àquela ligeira redução no sinal SFG de combinação de polarização SSP 
na região espectral da cabeça polar (FIGURA 39). Esta redução de sinal pode ser interpretada como um pequeno aumento da desordem das cabeças polares, visto que o sinal SFG nas outras polarizações (SPS e PPP) permanece nulo, i.e. não foi alterado. Isso porque se um pico diminuir em uma combinação de polarização e aumentar em outra seria um forte indicativo de que houve uma reorientação dos grupos fosfato na interface, e não de que tais grupos estivessem mais desordenados (que resultaria na queda de sinal SFG em todas as combinações de polarizações simultaneamente). Vale ressaltar que tais quitosanas interfaciais que interagem com as cabeças polares de $\operatorname{DPPC}( \pm)$ não foram detectadas nos espectros SFG. Logo, poucas delas devem formar uma camada dinâmica/fluida provavelmente abaixo das principais redes de ligações de hidrogênio das moléculas de água interfaciais. É possível que tais moléculas de quitosana interajam entre si (por interações hidrofóbicas e/ou de hidrogênio) nesta camada abaixo dos lipídeos e de água interfaciais, mas por serem dinâmicas ou por serem muito poucas nós não as detectamos. Logo, não podemos confirmar esta hipótese de interação quitosanaquitosana na subcamada da interface líquido-ar.

No caso de monocamadas de $\operatorname{DPPG}(-)$, que simulam as biomembranas bacterianas (FIGURAS 50.a-b), as alterações no processo de compressão isotérmica do filme lipídico na presença dos OQ na subfase aquosa são enormes(FIGURA 32). Há uma nítida expansão do filme devido à presença dos $\mathrm{OQ}\left(\Delta \sigma \approx 13 \AA^{2} /\right.$ molécula). Embora nestes experimentos de compressão isotérmica eles tenham causado uma drástica expansão do filme de DPPG, os fosfolipídeos na monocamada permanecem em uma conformação de alto grau de empacotamento lipídico (parâmetro R $>1$ nos espectros SFG das caudas hidrofóbicas) (FIGURA 35). Tal condição indica que os OQ tendem a se agregar formando ilhas de polímero inseridas na monocamada dos fosfolipídeos (FIGURA 50.b). Tais ilhas poderiam ser interpretadas como poros na membrana: regiões poliméricas em que importantes constituintes celulares poderiam extravazar por ali, como já visto em estudos in vivo na literatura. ${ }^{53-56}$ Além disso, essas ilhas tenderiam a empurrar os fosfolipídios, causando esta drástica expansão do filme (ocupando espaço na interface líquido-ar) e fazendo com que os DPPG(-) se empacotem mais ainda (tendendo a diminuir o espaço interlipídio, mantendo a conformação all-trans). Os espectros de SFG do grupo fosfato das cabeças polares dos DPPGs(-) mostram uma significativa interação com os $\mathrm{OQ}$, indicando que além da sua inserção no filme, há uma interação dos mesmos 
com os grupos polares aniônicos dos lipídeos (FIGURAS 42-44). Nos espectros SFG dos grupos fosfato dos lipídeos, é evidente que a cabeça polar do DPPG muda de comportamento na presença de $\mathrm{OQ}$, sobretudo na combinação SSP, como aconteceu no caso do PAH (FIGURA 42). Na água pura, os grupos fosfatos dos DPPGs ficavam randomicamente distribuídos (provavelmente se movimentando aleatoriamente devido às repulsões eletrostáticas no meio fluido), gerando um sinal nulo de SFG (típico de meios centrossimétricos). Quando sob a presença dos $\mathrm{OQ}$, as cabeças polares dos fosfolipídeos adquirem uma orientação preferencial ao longo do eixo-z, gerando sinal SFG na combinação SSP. Portanto, assim como no caso do PAH, os oligômeros de quitosana também restringem a movimentação das cabeças polares dos DPPGs ao interagirem com elas (FIGURAS 50.a-c). No entanto, surpreendentemente, aparece um pico novo na combinação de polarizações SPS em $\approx 1033 \mathrm{~cm}^{-1}$. Pela literatura, este pico pode estar relacionado tanto às vibrações dos $O Q$ (provavelmente devido às ilhas isoladas de OQ), quanto a estiramentos do grupo fosfato de fosfolipídeos de cabeça polar PG que estão na fase cristalina (eventualmente devido ao alto grau de empacotamento lipídico e indicando uma pequena reorientação da cabeça polar ao longo do plano-xy). Ambas as interpretações são coerentes no contexto do mecanismo de interação proposto para as quitosanas. Experimentos complementares teriam de ser feitos para confirmar a atribuição deste pico. Todos esses resultados foram obtidos usando a metodologia \#1 e estão sumarizados nas FIGURAS 49-50.

Até aqui, usando somente a metodologia\#1, as informações termodinâmicas estacionárias dos filmes de Langmuir associadas às informações moleculares fornecidas pelos espectros vibracionais SFG foram suficientes para definir e distinguir as interações moleculares entre polieletrólitos antimicrobianos e modelos de membranas celulares "tipo-bacteriana" e "tipo-humana". Mais do que isso, todos os resultados apresentados aqui estão em acordo com evidências da literatura do efeito desses polieletrólitos em células vivas. No entanto, todos esses estudos de interação foram realizados levando em conta a formação de uma membrana modelo sob a presença de antimicrobianos já solubilizados na subfase aquosa. Eles não dizem respeito à ação de um antimicrobiano quando este encontra uma membrana já formada. Na literatura, em geral, a interação de sais ou biomoléculas na subfase com filmes de Langmuir é investigada utilizando a metodologia 1 ou a metodologia 2, mas estudos comparativos - sobretudo do ponto de vista molecular - não são de nosso conhecimento. Então, nós realizamos um estudo 
comparativo usando a metodologia (\#2), a que injeta uma solução de antimicrobianos na subfase (água pura) de um Filme de Langmuir já formado a uma pressão superficial de interesse $(\pi=30 \mathrm{mN} / \mathrm{m})$ (FIGURA 45).

Os resultados da metodologia \#2 verificaram que os OQ de fato conseguem penetrar, mas a expansão causada nos filmes lipídicos é muito menor que o da metodologia \#1(FIGURAS 32 e 45). Portanto, nossos resultados mostram que há diferenças detectáveis em função da metodologia utilizada, o que é muito relevante para guiar trabalhos futuros que utilizem filmes de Langmuir como modelos de membrana. Muito provavelmente, esta pequena expansão é consequência da formação de ilhas menores de OQ nas monocamadas de DPPG(-). Além disso, os espectros SFG das cabeças polares por esta metodologia (\#2) foram muito semelhantes à anterior (\#1), mas menos intensos, coerente com a menor expansão (FIGURAS 47-48). Embora na polarização SPS o pequeno pico em $\approx 1033 \mathrm{~cm}^{-1}$ não exista no espectro da metodologia \#2 (FIGURA 48), isso pode ser explicado devido à pequena expansão no filme gerando um sinal indetectável nesta região. Ambas as possíveis atribuições deste pico ainda seriam válidas: ele sumiu devido ao fato de haver pouca quitosana penetrada no filme $e / o u$ porque a expansão foi pequena demais para forçar uma organização das cabeças polares na fase cristalina (a indução de empacotamento não foi tão grande). Então, na prática, acreditamos que ambas as metodologias - por compressão isotérmica e por injeção fornecem o mesmo tipo de informação a respeito do mecanismo de interação dos polieletrólitos OQ e PAH com as membranas modelo "tipo-bacterianas". Em outras palavras, acreditamos que, embora a magnitude do efeito seja diferente em cada metodologia, o mecanismo de ação é o mesmo.

Em um primeiro momento, como os espectros SFG da cabeça polar pelas metodologias \#1 e \#2 dariam as mesmas informações a respeito do mecanismo de interação, ficamos inclinados a pensar que realizar estudos de espectroscopia SFG usando somente a metodologia \#2 fosse suficiente, visto que seria uma situação mais realista (i.e., a metodologia \#1 seria desnecessária porque não prova a capacidade de penetração do antimicrobiano). Não obstante, se levarmos em conta que o processo para desencadear a morte celular bacteriana possa ser divido em várias etapas, a metodologia \#2 estaria somente relacionada à de penetração em uma membrana já formada, envolvendo a primeira etapa (adsorção guiada por interações eletrostáticas) e a segunda 
etapa (penetração da monocamada, guiada por ligações de hidrogênio, íon-dipolo e hidrofóbicas). Por outro lado, como as membranas biológicas são estruturas celulares dinâmicas, mudando o grau de compactação dos lipídeos diante das diversas respostas intra e extracelulares, a metodologia \#1 estaria mais relacionada a uma terceira etapa de interação, pois levaria em conta um antimicrobiano já presente na membrana e/ou no meio extracelular enquanto a estrutura (empacotamento) da membrana é alterada(o). Logo, a metodologia \#1 levaria em conta as situações ambientais e as diferentes fases do ciclo celular que proporcionam diferentes níveis de empacotamento lipídico de uma membrana biológica real (como, por exemplo, durante a divisão celular). Portanto, os resultados da metodologia \#1 são complementares aos da metodologia \#2, visto que podem ser interpretados como uma terceira fase de interação ( $S E$ a primeira etapa de penetração ocorrer!). Desta forma, todos os estudos feitos nesse trabalho se complementam entre si e dão uma visão muito detalhada dos possíveis mecanismos de ação antimicrobiana que compostos que atuam em membranas biológicas eventualmente podem desenvolver. 


\section{CONCLUSÕES}

O atual cenário preocupante do crescente número de casos de microrganismos patogênicos com resistência a antibióticos urge a descoberta de novas moléculas e novas estratégias antimicrobianas. Neste sentido, antimicrobianos poliméricos que atuam nas biomembranas das células patogênicas são de alto interesse, visto que há poucas alternativas possíveis para a aquisição de resistência a eles. Embora haja um enorme interesse da comunidade científica nesse tema, faltam trabalhos que visam abordar em nível molecular as interações de tais polímeros com biomembranas (membranas de células vivas) ou com modelos biomiméticos simplificados (membranas artificiais). Neste trabalho, investigamos em nível molecular a interação polímeros catiônicos antimicrobianos em modelos biomiméticos de membranas celulares (bacterianas e de células humanas).

Os modelos de interação molecular propostos estão sumarizados nas FIGURAS 49-50 e dão a uma visão geral de como os OQ e o PAH perturbam de maneiras diferentes os modelos de membrana que usamos. Embora tais modelos de membrana sejam muito simplificados comparados ao sistema vivo real, nossos resultados estão totalmente coerentes com os resultados já disponíveis na literatura em sistemas vivos. Tal fato fortalece a hipótese de que Filmes de Langmuir de DPPC $( \pm)$ e $\operatorname{DPPG(-)}$ são ótimos modelos de membrana, pois incorporaram os principais parâmetros envolvidos na interação de polímeros antimicrobianos e membranas reais (fluidez bidimensional, composição e empacotamento lipídicos controláveis).

Dentre os polímeros antimicrobianos estudados, o PAH perturba os Filmes de Langmuir de modo semelhante ao modelo tipo carpete dos AMPs. Provavelmente, o PAH por ter uma cadeia mais longa, menos volumosa e estar menos enovelada devido a uma maior densidade de cargas na cadeia, consegue encontrar facilmente um espaço entre as cabeças polares de ambos os fosfolipídeos envolvidos: DPPC (tipo-humano) ou DPPG (tipo-bacteriano). Logo, por interagir de forma semelhante com ambas as membranas, o modo de ação do PAH demonstrou ser pouco seletivo, independentemente do tipo de cabeça dos lipídios (aniônica ou zwitteriônica). Tais interações que provavelmente são ligações de hidrogênio e/ou eletrostáticas, uma vez que afetam principalmente a rede de ligações de hidrogênio das moléculas interfaciais e o potencial membrana de ambos os 
modelos. Acreditamos que as eventuais interações hidrofóbicas do PAH com os modelos de membrana sejam extremamente sutis em DPPC e, sobretudo, são desprezíveis em DPPG devido à magnitude de outras forças (eletrostáticas) envolvidas neste caso.

Já os OQ têm comportamento totalmente dependente do tipo de carga da cabeça polar presente nos lipídeos da monocamada. Tal fato pode reflete a sua alta seletividade para perturbar membranas modelo tipo-bacterianas(-), e não perturbar membranas tipo-humanas( \pm ). Além disso, esta alta seletividade fortalece a hipótese de que a primeira etapa de interação (mediada por interações eletrostáticas) seja, de fato, decisiva para a biocompatibilidade de tais polímeros antimicrobianos com células humanas.

Em membranas tipo-humanas( \pm ), os OQ conseguem se adsorver na interface líquido-ar, mas permanecem interagindo somente com as cabeças polares sem afetar o empacotamento lipídico, nem a organização das águas interfaciais ou o potencial de membrana. Provavelmente isso é consequência de os OQ serem cadeias poliméricas mais volumosas (estrutura química formada por hexoses cíclicas), que não encontram espaço entre as cabeças polares dos lipídeos tão facilmente quanto o PAH. Assim, eles tendem a interagir com as cabeças polares (sobretudo via interação íon-dipolo de longo alcance) e não penetram na região apolar. Vale ressaltar que as quitosanas interfaciais não foram detectadas nos espectros SFG de DPPC( \pm ). Logo, poucas delas devem formar uma subcamada dinâmica/fluida provavelmente abaixo das principais redes de ligações de hidrogênio das moléculas de água interfaciais. Existe também a hipótese de que tais moléculas de quitosana interajam entre si (por interações hidrofóbicas e/ou de hidrogênio), mas não tivemos como confirmar isso com nossos dados.

Em membranas tipo-bacterianas(-), os OQ adsorvidos causem uma drástica perturbação (expansão do filme). Com este aumento de área tão dramático, se esperaria que os lipídeos de DPPG(-) na interface deixassem de ter a conformação all-trans (indicativo de lipídeos bem empacotados) e passassem a ter mais conformação do tipo gauche (indicativo de lipídeos pouco empacotados). Entretanto, a análise por espectroscopia SFG mostrou que os fosfolipídeos permaneceram na conformação de alto grau de empacotamento. Tal condição sugere que os $O Q$ ocupam espaço na interface agregando-se entre si, formando ilhas de polímero separadas do mar de fosfolipídeos ao 
redor. Provavelmente é nesta região de ilhas de quitosana que a membrana celular pode perder o controle do fluxo e permeabilidade seletiva de substâncias que a atravessam como se fosse um poro. Além disso, devido à expansão (ocupando espaço na interface líquido-ar), provavelmente tais ilhas empurrariam o fosfolipídios ao redor, fazendo com que os lipídeos de DPPG(-) se empacotem mais ainda (tendendo a diminuir o espaço interlipídeo, mantendo a conformação all-trans. Assim, as moléculas de OQ que estão no poro interagem muito entre si, tendendo a acumular ainda mais moléculas nessas ilhas, sobretudo por interações hidrofóbicas e de hidrogênio entre os grupos hidroxila e amina. Tal resultado, até onde sabemos é inédito, pode auxiliar trabalhos de desenvolvimento de novos polímeros antimicrobianos no futuro, uma vez que em nenhum momento se pensou que uma interação antimicrobiano-antimicrobiano mais intensa que antimicrobiano-membrana fosse relevante para a atividade bactericida. Inclusive, é possível que tais ilhas de quitosana estejam relacionadas àquelas estruturas semelhantes a dentes observadas por microscopia eletrônica nas paredes celulares de bactérias. ${ }^{56}$ É possível que aqueles "dentes" sejam as próprias quitosanas ou dobramentos da membrana semelhante a bolhas de lipídeo causadas pelas pressão lateral elas proporcionariam, também observados em outros trabalhos na literatura. ${ }^{55}$

Por terem cargas opostas, tanto as quitosanas, quanto o PAH interagem intensamente com as cabeças polares de $\operatorname{DPPG}(-)$, principalmente por interações eletrostáticas, causando uma blindagem das cargas interfaciais, afetando tanto a organização das moléculas de água da vizinhança da monocamada, quanto o potencial de membrana. Nestes casos, surpreendentemente, os espectros de SFG das cabeças polares dos DPPGs(-) em água pura (controle) eram todos nulos nas diferentes combinações de polarizações (SSP, SPS e PPP). Isso é uma evidência de que as cabeças polares dos filmes de Langmuir de DPPG(-) em água pura (controle) não tem uma orientação específica na interface. Logo, provavelmente as cabeças polares de PG são altamente dinâmicas em água pura devido às repulsões eletrostáticas entre si no meio fluido. Até onde sabemos, isto é um resultado novo, inexistente na literatura. Mais interessante ainda é que, quando os polieletrólitos antimicrobianos estão presentes, eles adsorvem na monocamada e interagem fortemente com as cabeças polares de DPPG(-), sobretudo por interações eletrostáticas, restringindo o seu comportamento dinâmico. Ambos os polímeros antimicrobianos (PAH e OQ) reorientam as cabeças polares de DPPG(-) em uma conformação molecular preferencial ao longo do eixo-z (perpendicular 
à interface). Além disso, ainda analisando esta região espectral, houve um aparecimento de um novo pico combinação de polarizações SPS em $\approx 1033 \mathrm{~cm}^{-1}$. As duas possíveis atribuições são coerentes com mecanismo de ação proposto de quitosanas em membranas tipo-bacterianas. Em uma, o pico estaria associado às vibrações das quitosanas presentes nas ilhas dos filmes de Langmuir de DPPG(-). Em outra, ele poderia estar associado aos estiramentos do grupo fosfato em fase cristalina, que seriam consequência do alto grau de empacotamento lipídico propiciado pelas as ilhas de quitosana que tendem a empurrar os lipídeos ao seu redor, reduzindo a distância lipídeo-lipídeo. Experimentos complementares teriam de ser feitos para esclarecer sem ambiguidades a atribuição deste pico.

Por fim, nós comparamos em nível molecular as interações entre os $\mathrm{OQ}$ e as cabeças polares de monocamadas de DPPG(-) frente a duas possíveis metodologias de estudo de filmes de Langmuir. Os espectros SFG de filmes de DPPG interagindo com quitosanas mostraram-se dependente do tipo de metodologia a ser utilizada, isto é as interações foram diferentes. A magnitude da perturbação da membrana foi menor para o caso em que o antimicrobiano teve que penetrar em uma monocamada lipídica já previamente formada (metodologia \#2), comparada à metodologia em que o antimicrobiano adsorvia na interface durante a compactação (formação) do filme de Langmuir de modo quase estacionário (\#1). Embora a intensidade das interações sejam diferentes, a interpretação geral foi a mesma neste caso. Entretanto, como a magnitude da interação não foi igual em ambas as metodologias, tal resultado sugere que não necessariamente sempre o tipo de interação também será o mesmo independentemente da metodologia. Até onde sabemos, esta evidência é nova e muito importante, pois, cada metodologia utilizada poderia ser interpretada como diferentes etapas consecutivas de interação do antimicrobiano e a membrana modelo. Assim, tais etapas poderiam ter tipos de interações diferentes e guiar o entendimento mais profundo de como compostos antimicrobianos perturbam as membranas. A metodologia (\#2), de dinâmica de injeção por exemplo, incorpora a $1^{\underline{a}}$ etapa (adsorção eletrostática) e $2^{\underline{a}}$ etapa (penetração na membrana) de interação de antimicrobianos com membranas modelo. Já e metodologia (\#1), que mede a afinidade de interação dos antimicrobianos com a os lipídeos da membrana durante a compactação (formação) da monocamada lipídica, estaria mais associado a uma $3^{\circ}$ etapa de interação (uma vez que o antimicrobiano está 
inserido na membrana e está sujeito a diferentes graus de empacotamento lipídico). Os espectros SFG de filmes de Langmuir usando esta metodologia estariam mais relacionados às interações moleculares do antimicrobiano já inserido na membrana frente às flutuações do empacotamento lipídico da membrana durante o ciclo da célula (divisão celular). 


\section{SUGESTÕES PARA FUTUROS EXPERIMENTOS}

[i]: ESPECTRO SFG (COMBINAÇÕES SSP, SPS, PPP) NA REGIÃO DAS CAUDAS HIDROFÓBICAS DO LIPÍDEO + ÁGUA $\left(2800 \mathrm{~cm}^{-1}-3800 \mathrm{~cm}^{-1}\right)$ USANDO A METODOLOGIA \#2 (POR INJEÇÃO). Motivo: verificar se de fato a interpretação do mecanismo de ação não varia diante da mudança de método.

[ii]: ESPECTRO SFG (COMBINAÇÕES SSP, SPS, PPP) DE DPPG EM ÁGUA PURA PARA ALTO VALOR DE PRESSÃO SUPERFICAL. Motivo: verificar se a interpretação do pico em $1033 \mathrm{~cm}^{-1}$ na combinação de polarização SPS pode ser devido à uma vibração da cabeça polar típica da fase cristalina do filme. Como neste caso o espectro é feito em água pura, se aparecer esse pico é sinal de que a interpretação de restrição extrema de movimentação da cabeça polar devido a um alto grau de empacotamento lipídico é verdadeira. Já os outros espectros nas outras combinações é mais para verificar como um filme de DPPG altamente empacotado se comporta.

[iii]: FAZER EXPERIMENTOS DE MICROSCOPIA POR ÂNGULO DE BREWSTER (BAM) EM MONOCAMDAS DE DPPG EM SOLUÇÃO DE OQ COMO SUBFASE (MET\#1). Motivo: verificar se as ilhas de OQ são visíveis por microscopia, isto é, se elas são da ordem de dezenas de mícrons ou se são nanoscópicas (invisíveis ao BAM).

[iv]: FAZER EXPERIMENTOS DE MICROSCOPIA POR ÂNGULO DE BREWSTER (BAM) EM MONOCAMDAS DE DPPG EM ÁGUA PURA. Motivo: acompanhar a estabilização da monocamada de DPPG a $30 \mathrm{mN} / \mathrm{m}$,

[v]: FAZER EXPERIMENTOS DE MICROSCOPIA POR ÂNGULO DE BREWSTER (BAM) EM MONOCAMDAS DE DPPG APÓS A INJEÇÃO DE OQ Motivo: fazer um estudo comparativo com o item [iii]. 
[vi]: FAZER EXPERIMENTOS DE ESPECTROSCOPIA SFG, BAM E MICROSCOPIA SFG VARIANDO A FRAÇÃO MOLAR DE FILMES LIPÍDICOS ENTRE DPPG E DPPC USANDO METODOLOGIA\#1 E METODOLOGIA \#2 (PARA AMBOS OS ANTIMICROBIANOS: PAH E OQ). Motivo: comparar o diagrama de fases de Filmes de Langmuir DPPC/DPPG interagindo com esses polieletrólitos frente às metodologias \#1 e \#2. Assim, teríamos uma noção melhor das várias etapas de interação molecular em vários modelos de membrana (mais realistas).

[vii]: VERIFICAR A MUDANÇA DE COMPORTAMENTO DESSES FILMES FRENTE A:

- variação de grupos funcionais desses polieletrólitos;

- variação do tamanho desses polieletrólitos;

- variação do pH da solução;

- variação da temperatura;

[*] FAZER EXPERIMENTOS DE HISTERESE ENTRE $30 \mathrm{mN} / \mathrm{m}$ a $35 \mathrm{mN} / \mathrm{m}$ COM OS ANTIMICROBIANOS NA SUBFASE E ACOMPANHÁ-LOS COM TÉCNICAS ÓPTICAS (BAM, SFG E MICRO-SFG). Motivo: seria como uma outra metodologia (\#3) para analisar o mecanismo de interação molecular antimicrobiano. A metodologia \#3 consiste em ficar variando a pressão de $30 \mathrm{mN} / \mathrm{m}$ a $35 \mathrm{mN} / \mathrm{m}$ a fim de detectar a dinâmica de penetração (tipo metodologia \#2) dos antimicrobianos que estão na subfase medindo a área superficial. 


\section{REFERÊNCIAS}

1 ALBERTS, B. et al. Biologia molecular da célula. 5. ed. São Paulo: Artmed, 2007.

2 WORLD HEALTH ORGANIZATION (WHO). Antibiotic resistance: a growing threat. 2012. Disponível em: <http://www.euro.who.int/en/what-we-do/healthtopics/disease-prevention/antimicrobial-resistance/news/news/2012/11/antibioticresistance-a-growing-threat $\geq$. Acesso em: 10 maio 2015.

3 NATIONAL INSTITUTES OF HEALTH (NIH). Quick facts. 2012. Disponível em: <http://www.niaid.nih.gov/topics/antimicrobialResistance/understanding/Pages/quic kFacts.aspx $\geq$. Acesso em: 10 maio 2015.

4 CENTERS FOR DISEASE CONTROL (CDC). Antimicrobial resistance posing growing health threat. 2011. Disponível em:

<http://www.cdc.gov/media/releases/2011/p0407_antimicrobialresistance.html $\geq$ Acesso em: 10 maio 2015.

5 BOCKSTAEL, K.; AERSCHOT, A. Antimicrobial resistance in bacteria. Central European Journal of Medicine, v. 4, n. 2, p. 141-155, 2009.

6 DAPTOMICINA. 2008. Disponível em:

<http://www.anvisa.gov.br/servicosaude/controle/rede_rm/cursos/rm_controle/opas_ web/modulo1/daptomicina.htm $\geq$. Acesso em: 10 maio 2015.

7 ENCYCLOPAEDIA Britannica. Antibiotic resistance. 2015. Disponível em: <http://global.britannica.com/EBchecked/topic/1027479/antibiotic-resistance>. Acesso em: 10 maio 2015.

8 BENVENISTE, R.; DAVIES, J. Mechanisms of antibiotic resistance in bacteria. Annual Review of Biochemistry, v. 42, p. 471-506, 1973.

doi:10.1146/annurev.bi.42.070173.002351.

9 ARIAS, C. A; MURRAY, B. E. The rise of the Enterococcus: beyond vancomycin resistance. Nature Reviews: microbiology, v. 10, n. 4, p. 266-278, 2012.

10 JAYARAMAN, R. Antibiotic resistance : an overview of mechanisms and a paradigm shift. Current Science, v. 96, n. 11, p. 1475-1484, 2009.

11 TARASZKIEWICZ, A. et al. Innovative strategies to overcome biofilm resistance. BioMed research international, v. 2013, p. 1-13, 2013.

12 HALL-STOODLEY, L.; COSTERTON, J. W.; STOODLEY, P. Bacterial biofilms: from the natural environment to infectious diseases. Nature Reviews: microbiology, v. 2, n. 2, p. 95-108, 2004. 
13 MONROE, D. Looking for chinks in the armor of bacterial biofilms. PLoS Biology, v. 5, n. 11, p. 2458-2461, 2007.

14 XU, J.; GORDON, J. I. Honor thy symbionts. Proceedings of the National Academy of Sciences of the United States of America, v. 100, n. 18, p. 10452-10459, 2, 2003.

$15 \mathrm{XU}$, J. et al. Evolution of symbiotic bacteria in the distal human intestine. PLoS Biology, v. 5, n. 7, p. 1574-1586, 2007.

16 ANTIMICROBIANOS: bases teóricas e uso clinico. 2008.

<http://www.anvisa.gov.br/servicosaude/controle/rede_rm/cursos/rm_controle/opas_ web/modulo1/conceitos.htm>. Acesso em: 10 maio 2015.

17 BOAL, D. Mechanics of the cell. $2^{\text {nd }}$ ed. Cambridge: Cambridge University Press, 2012.

18 MARR, A. G. Growth rate of Escherichia coli. Microbiological Reviews. v. 55, n. 2, p. 316-333, 1991.

19 FOSSUM, S.; CROOKE, E.; SKARSTAD, K. Organization of sister origins and replisomes during multifork DNA replication in Escherichia coli. EMBO Journal, v. 26, n. 21, p. 4514-4522, 2007.

20 THOMAS, C. M.; NIELSEN, K. M. Mechanisms of, and barriers to, horizontal gene transfer between bacteria. Nature Reviews: microbiology, v. 3, n. 9, p. 711-721, 2005.

21 ENCYCLOPAEDIA Britannica. Horizontal gene transfer, 2015. Disponível em: <http://global.britannica.com/science/horizontal-gene-transfer> . Acesso em: 10 maio 2015.

22 ENCYCLOPAEDIA Britannica. Conjugation sexual process, 2015. Disponível em: <http://global.britannica.com/science/conjugation-sexual-process $>$. Acesso em: 10 maio 2015.

23 ENCYCLOPAEDIA Britannica. Transduction microbiology, 2015. Disponível em: <http://global.britannica.com/science/transduction-microbiology>. Acesso em: 10 maio 2015.

24 ENCYCLOPAEDIA Britannica. Trasnformation biology, 2015. Disponível em: <http://global.britannica.com/science/transformation-biology>. Acesso em: 10 maio 2015.

25 KENAWY, E.-R.; WORLEY, S. D.; BROUGHTON, R. The chemistry and applications of antimicrobial polymers: a state-of-the-art review. Biomacromolecules, v. 8, n. 5, p. 1359-1384, 2007.

26 WANG, Y. et al. Membrane activity of antimicrobial phenylene ethynylene based polymers and oligomers. Soft Matter, v. 8, n. 33, p. 8547-8558, 2012. 
27 MUÑOZ-BONILLA, A.; FERNÁNDEZ-GARCÍA, M. Polymeric materials with antimicrobial activity. Progress in Polymer Science, v. 37, n. 2, p. 281-339, 2012.

28 SIEDENBIEDEL, F.; TILLER, J. C. Antimicrobial polymers in solution and on surfaces: overview and functional principles. Polymers, v. 4, n. 4, p. 46-71, 2012.

29 IARIKOV, D. D. et al. Antimicrobial surfaces using covalently bound polyallylamine. Biomacromolecules, v. 15, n. 1, p. 169-176, 13, 2014.

30 MARLETTA, B. A. et al. Rapid conversion of poly ( $p$-phenylenevinylene ) films at low temperatures. Advanced Materials, v.12 . n. 1, p. 69-74, 2000.

31 YEAMAN, M. R.; YOUNT, N. Y. Mechanisms of antimicrobial peptide action and Resistance. Pharmacological Reviews, v. 55, n. 1, p. 27-55, 2003.

32 WIMLEY, W. C.; HRISTOVA, K. Antimicrobial peptides: successes, challenges and unanswered questions. Journal of Membrane Biology, v. 239, n. 1-2, p. 27-34, 2011.

33 CHEMBURU, S. et al. Light-induced biocidal action of conjugated polyelectrolytes supported on colloids. Langmuir: the ACS journal of surfaces and colloids, v. 24, n. 19, p. 11053-11062, 2008.

34 CORBITT, T. S. et al. Light and dark biocidal activity of cationic poly(arylene ethynylene) conjugated polyelectrolytes. Photochemical \& Photobiological Sciences, v. 8, n. 7, p. 998-1005, 2009.

35 BROGDEN, K. A. Antimicrobial peptides: pore formers or metabolic inhibitors in bacteria? Nature Reviews: microbiology, v. 3, n. 3, p. 238-50, 2005.

36 ISHITSUKA, Y. et al. Insertion selectivity of antimicrobial peptide protegrin-1 into lipid monolayers: effect of head group electrostatics and tail group packing. Biochimica et Biophysica Acta (BBA), v. 1758, n. 9, p. 1450-60, 2006.

37 JORI, G. et al. Photodynamic therapy in the treatment of microbial infections: basic principles and perspective applications. Lasers in Surgery and Medicine, v. 38, n. 5, p. 468-81, 2006.

38 CORBITT, T. S. et al. Conjugated polyelectrolyte capsules: light-activated antimicrobial micro "Roach Motels". ACS Applied Materials \& Interfaces, v. 1, n. 1, p. $48-52,2009$.

39 NAZZAL, S. et al. Nanotechnology in antimicrobial photodynamic inactivation. Journal of Food and Drug Analysis, v. 19, n. 4, p. 383-395, 2011.

40 DOLMANS, D. E. J. G. J.; FUKUMURA, DAI; JAIN, R. K. Photodynamic therapy for cancer. Nature Reviews: cancer, v. 3, n. 5, p. 380-387, 2003. 
41 SHARMA, A.; SHARMA, U. S. Liposomes in drug delivery: progress and limitations. International Journal of Pharmaceutics, v. 154, p. 123-140, 1997.

42 MOURYA, V. K.; INAMDAR, N. N. Trimethyl chitosan and its applications in drug delivery. Journal of Materials Science: materials in medicine, v. 20, n. 5, p. 1057-79, 2009.

43 PROW, T. W. et al. Nanoparticles and microparticles for skin drug delivery. Advanced Drug Delivery Reviews, v. 63, n. 6, p. 470-91, 2011.

44 ALVARENGA, E. S. DE. Characterization and properties of chitosan. In: LNASHAR M. (Ed.). Biotechnology of biopolymers. Rijeka, Croatia: In Tech, 2011. p. 91-108.

45 DE BRITTO, D. et al. Quaternary salts of chitosan: history, antimicrobial features, and prospects. International Journal of Carbohydrate Chemistry, v. 2011, n. 312539, p. 1-12, 2011.

46 GOY, R. C.; DE BRITTO, D. DE; ASSIS, O. B. G. A review of the antimicrobial activity of chitosan. Polímeros: ciência e tecnologia, v. 19, n. 3, p. 1-7, 2009.

47 SILVA-DIAS, A et al. Anti-biofilm activity of low-molecular weight chitosan hydrogel against Candida species. Medical Microbiology and Immunology, v. 203, n. 1, p. 25-33, 2014.

48 ZHANG, A. et al. Chitosan coupling makes microbial biofilms susceptible to antibiotics. Scientific Reports, v. 3, p. 3364, 2013. doi: 10.1038/srep03364.

49 PARK, S.-C. et al. Antimicrobial Action of Water-Soluble $\beta$-Chitosan against Clinical Multi-Drug Resistant Bacteria. International Journal of Molecular Sciences, v. 16, n. 4, p. 7995-8007, 10, 2015.

50 CHAVEZ DE PAZ, L. E. et al. Antimicrobial effect of chitosan nanoparticles on Streptococcus mutans biofilms. Applied and Environmental Microbiology, v. 77, n. 11, p. 3892-3895, 2011.

51 RÚNARSSON, Ö. V. et al. Antibacterial activity of methylated chitosan and chitooligomer derivatives: synthesis and structure activity relationships. European Polymer Journal, v. 43, n. 6, p. 2660-2671, 2007.

52 RÚNARSSON, Ö. V. et al. Antibacterial activity of N-quaternary chitosan derivatives: synthesis, characterization and structure activity relationship (SAR) investigations. European Polymer Journal, v. 46, n. 6, p. 1251-1267, 2010.

53 RAAFAT, D. et al. Insights into the mode of action of chitosan as an antibacterial compound. Applied and Environmental Microbiology, v. 74, n. 12, p. 3764-73, 2008.

54 RABEA, E. I. et al. Chitosan as antimicrobial agent: applications and mode of action. Biomacromolecules, v. 4, n. 6, p. 1457-65, 2003. 
$55 \mathrm{KONG}, \mathrm{M}$. et al. Antimicrobial properties of chitosan and mode of action: a state of the art review. International journal of food microbiology, v. 144, n. 1, p. 51-63, 15, 2010.

56 LIU, H. et al. Chitosan kills bacteria through cell membrane damage. International journal of food microbiology, v. 95, n. 2, p. 147-55, 1, 2004.

57 PAVINATTO, F. J. et al. Interaction of Chitosan with Cell Membrane Models at the Air Water Interface. Biomacromolecules, p. 1633-1640, 2007.

58PAVINATTO, F. J. et al. Probing chitosan and phospholipid interactions using Langmuir and Langmuir-Blodgett films as cell membrane models. Langmuir: the ACS journal of surfaces and colloids, v. 23, n. 14, p. 7666-71, 3, 2007.

59CASELI, L. et al. Chitosan as a Removing Agent of -Lactoglobulin from Membrane Models. Langmuir: the ACS journal of surfaces and colloids, n. 12, p. 4150-4156, 2008.

60 PAVINATTO, A. et al. Electrostatic interactions are not sufficient to account for chitosan bioactivity. ACS Applied Materials \& Interfaces, v. 2, n. 1, p. 246-51, 2010.

61 PAVINATTO, A. et al. Low molecular-weight chitosans are stronger biomembrane model perturbants. Colloids and Surfaces B: biointerfaces, v. 104, p. 48-53, 2013. DOI:10.1016/j.colsurfb.2012.

62 PAVINATTO, F. J. et al. Cholesterol mediates chitosan activity on phospholipid monolayers and Langmuir-Blodgett films. Langmuir : the ACS journal of surfaces and colloids, v. 25, n. 17, p. 10051-61, 2009.

63 KRAJEWSKA, B.; WYDRO, P.; JAŃCZYK, A. Probing the Modes of Antibacterial Activity of Chitosan. Effects of $\mathrm{pH}$ and Molecular Weight on Chitosan Interactions with Membrane Lipids in Langmuir Films. Biomacromolecules, v. 12, n. 11, p. 4144-4152, 14, 2011.

64KRAJEWSKA, B.; WYDRO, P.; KYZIOŁ, A. Chitosan as a subphase disturbant of membrane lipid monolayers. The effect of temperature at varying $\mathrm{pH}$ : I. DPPG. Colloids and Surfaces A: physicochemical and engineering aspects, v. 434, p. 349-358, 2013.

65KRAJEWSKA, B.; KYZIOŁ, A.; WYDRO, P. Chitosan as a subphase disturbant of membrane lipid monolayers. The effect of temperature at varying $\mathrm{pH}$ : II. DPPC and cholesterol. Colloids and Surfaces A: physicochemical and engineering aspects, v. 434, p. 359-364, 2013.

66 VOET, D.; VOET, J. Bioquímica. 3aㅡ ed. Porto Alegre: Artmed, 2006.

67 MADIGAN, M.T. et al. Microbiologia de Brock. 12ª ed. Porto Alegre: Artmed, 2010.

68 VOLPATI, D. et al. Vibrational spectroscopy for probing molecular-level interactions in organic films mimicking biointerfaces. Advances in Colloid and Interface Science, v. 
207, p. 199-215, 2014.

69 SHEN, Y. R. Surface properties probed by second-harmonic and sum-frequency generation. Nature, v. 337, n. 9, p. 519-524, 1989.

70 DU, Q. et al. Vibrational spectroscopy of water at the vapor/water interface. Physical Review Letters, v. 70, n. 15, p. 2313-2316, 1993.

71 GUYOT-SIONNEST, P.; HUNT, J. H.; SHEN, Y. R. Sum-frequency vibrational spectroscopy of a Langmuir film: study of a molecular orientation of a two-dimensional system. Physical Review Letters, v. 59, n. 14, p. 1597-1600, 1987.

72 MIRANDA, P. B.; SHEN, Y. R. Liquid interfaces: a study by sum-frequency vibrational spectroscopy. Journal of Physical Chemistry B, v. 103, n. 17, p. 3292-3307, 1999.

73 MIRANDA, P. B.; DU, Q.; SHEN, Y. R. Interaction of water with a fatty acid Langmuir film. Chemical Physics Letters,v.286, n.1, p. 1-8, 1998.

74 MIRANDA, P. B. et al. Surfactant monolayers at solid - liquid interfaces :

conformation and interaction. Thin Solid Films, v. 329, n. 7300, p. 161-165, 1998.

75 WIKIPEDIA. Membrana plasmática, 2015. Disponível em:

<http://pt.wikipedia.org/wiki/Membrana_plasmática> . Acesso em: 10 maio 2015.

76 YEAGLE, P. L. The structure of biological membranes. $2^{\text {nd }}$ ed. Boca Raton: CRC Press, 2004.

77 WIKIPEDIA. Gram staining, 2015. Disponível em: <https://en.wikipedia.org/?title=Gram_staining >. Acesso em: 10 maio 2015.

78 WIKIPEDIA. Peptidoglycan, 2015. Disponível em: <http://en.wikipedia.org/wiki/Peptidoglycan>. Acesso em: 10 maio 2015.

79 LOYOLA UNIVERSITY CHICAGO. Gram stain technique, 2015. Disponível em: <http://priede.bf.lu.lv/grozs/Mikrobiologijas/Mediciniska_mikrobiol/Loyola\%20Univ_ $\% 20$ Health\%20Univ_\%20Health\%20Sys-

\%20Microbiology\%20\&\%20Immunology\%C2\%A0\%20GRAM\%20STAIN\%20TECHNIQ UE.htm>. Acesso em: 10 maio 2015.

80 WIKIPEDIA. Crystal violet, 2015. Disponível em:

<https://en.wikipedia.org/wiki/Crystal_violet>. Acesso em: 10 maio 2015.

81 CENTRO DE BIOENERGÉTICA. Bactérias Gram-positivas, 2015. Disponível em: $<$ http://microbioenergetica.squarespace.com/bacteriologa/2014/7/21/bacteriasgram-positivas>. Acesso em: 10 maio 2015.

82 EPAND, R. M.; EPAND, R. F. Lipid domains in bacterial membranes and the action of antimicrobial agents. Biochimica et Biophysica Acta (BBA), v. 1788, n. 1, p. 289-94, 
2009.

83 EPAND, R. F.; SAVAGE, P. B.; EPAND, R. M. Bacterial lipid composition and the antimicrobial efficacy of cationic steroid compounds (Ceragenins). Biochimica et Biophysica Acta (BBA), v. 1768, n. 10, p. 2500-9, 2007.

84 WIKIPEDIA. Lipopolysaccharide, 2015. Disponível em: <https://en.wikipedia.org/wiki/Lipopolysaccharide>. Acesso em: 10 maio 2015

85 SIGMA ALDRICH. 2-Keto-3-deoxyoctonate ammonium salt, 2015. Disponível em: <http://www.sigmaaldrich.com/catalog/product/aldrich/k2755?lang=pt\&region=BR>. Acesso em: 10 maio 2015.

86 SIGMA ALDRICH. D-(+)-Glucose, 2015. Disponível em: <http://www.sigmaaldrich.com/catalog/product/sigma/g8270?lang=pt\&region=BR>. Acesso em: 10 maio 2015.

87 SIGMA ALDRICH. D-(+)-Galactose, 2015. Disponível em: <http://www.sigmaaldrich.com/catalog/product/sial/g0750?lang=pt\&region=BR>. Acesso em: 10 maio 2015.

88 SIGMA ALDRICH. L-Rhamnose, 2015. Disponível em: <http://www.sigmaaldrich.com/catalog/product/aldrich/w373011?lang=pt\&region=B $\mathrm{R}>$. Acesso em: 10 maio 2015.

89 ENZYME Database. CDP-abequose, CDP-ascarylose, CDP-paratose and CDPtyrelose biosynthesis, 2015. Disponível em: <http://www.enzymedatabase.org/reaction/polysacc/CDPabe.html>. Acesso em: 10 maio 2015.

90 WIKIPEDIA. Colitose, 2015. Disponível em:

<https://en.wikipedia.org/wiki/Colitose>. Acesso: em 10 maio 2015.

91 WIKIPEDIA. Membrane lipids, 2015. Disponível em:

<https://en.wikipedia.org/wiki/Membrane_lipids>. Acesso: em 10 maio 2015.

92 AVANTI POLAR LIPIDS. DPPC, 2015. Disponível em:

$<$ https://www.avantilipids.com/index.php?option=com_content\&view=article\&id=216 \&Itemid=206\&catnumber=850355>. Acesso em: 10 maio 2015.

93 AVANTI POLAR LIPIDS. 16:0 PG, 2015. Disponível em:

$<$ https://www.avantilipids.com/index.php?option=com_content\&view=article\&id=585 \&Itemid=233\&catnumber=840455>. Acesso em: 10 maio 2015.

94 ULMAN, A. An introduction to ultrathin organic films. New York: Academic Press, 1991.

95 DREIER, J. Orientational texture of lipid bilayer and monolayer domains. 2012. 141 p. Thesis (PhD in Biophysics) - center for biomembrane physics, Department of 
Physics, Chemistry and Pharmacy, University of Southern Denmark, 2012.

96 AKBARZADEH, A. et al. Liposome: classification, preparation, and applications. Nanoscale Research Letters, v. 8:102, n. 1, p. 1-9, 2013.

97 BERG, J. C. An introduction to interfaces \& colloids. Singapore: World Scientific Publishing, 2010.

98 BROCKMAN, H. Lipid monolayers : why use half a membrane to characterize proteinmembrane interactions? Current Opinion in Structural Biology, v. 9, n.4, p. 438-443, 1999.

99 MARSH, D. Components of the lateral pressure in lipid bilayers deduced from H II phase dimensions. Biochimica et Biophysica Acta (BBA), v. 1279, n. 2, p. 119-123, 1996.

100 MARSH, D. Lateral pressure in membranes. Biochimica et Biophysica Acta (BBA), v. 1286, n. 3, p. 183-223, 1996.

101 ROKE, S. Nonlinear spectroscopy of bio-interfaces. International Journal of Materials Research, v. 102, n. 7, p. 906-912, 2011.

102 MARTIN, D. Nanobiotechnology of biomimetic membranes. Boston: Springer, 2007.

103 BIOLIN Scientific. Langmuir, Langmuir-Blodgett, Langmuir-Schaefer

Technique, 2015. Disponível em: <http://www.biolinscientific.com/technology/l-lb-lstechnique>. Acesso em: 10 maio 2015.

104 BOYD, R. W. Nonlinear optics. 3 ${ }^{\text {rd }}$ ed. Burlington: Academic Press, 2008.

105 POWERS, P. E. Fundamentals of nonlinear optics. Boca Raton: CRC Press, 2011.

106 SHEN, Y. R. The principles of nonlinear optics. New Jersey: John Wiley \& Sons, 2003.

107 SILVA, H. S. Estudo da adsorção de polieletrólitos e do ordenamento molecular de filmes poliméricos automontados através da óptica não-linear. 2011. 154 p. Tese (Doutorado em Ciências - Física Aplicada) - Instituto de Física de São Carlos, Universidade de São Paulo, 2011.

108 LAMBERT, A. G.; DAVIES, P. B.; NEIVANDT, D. J. Implementing the theory of sum frequency generation vibrational spectroscopy: a tutorial review. Applied Spectroscopy Reviews, v. 40, n. 2, p. 103-145, 2005.

109 SIGMA ALDRICH. Poly(allylamine hydrochloride). 2015. Disponível em: <http://www.sigmaaldrich.com/catalog/product/aldrich/283215?lang=pt\&region=BR >. Acesso em: 10 maio 2015. 
110 MOTTI, S. G. Espectroscopia não linear de interfaces aplicada ao estudo de transistores poliméricos. 2014. 87 p. Dissertação (Mestrado em Ciências Desenvolvimento, Caracterização e Aplicação de Materiais) - Escola de Engenharia de São Carlos, Universidade de São Paulo, 2014.

111 MA, G.; ALLEN, H. C. DPPC Langmuir monolayer at the air - water interface : probing the tail and head groups by vibrational sum frequency generation spectroscopy.

Langmuir : the ACS journal of surfaces and colloids, v. 22, n. 12, p. 5341-5349, 2006.

112 TELESFORD, D.-M. Langmuir trough and Brewster angle microscopy study of model lung surfactant monolayers at the air/aqueous interface. 2012. $131 \mathrm{p}$. (Master Thesis - Chemistry) - Department of Chemistry and Biochemistry, The Ohio State University, 2012.

113 GARIDEL, P.; BLUME, A.; HU, W. A. Fourier transform infrared spectroscopic study of the interaction of alkaline earth cations with the negatively charged phospholipid 1,2 dimyristoyl- sn -glycero-3-phosphoglycerol. Biochimica et Biophysica Acta (BBA), v. 1466, p. 245-259, 2000.

114 TIPSON, R. S. Infrared spectroscopy of carbohydrates: a review of the literature. Washington, D. C.: Department of Commerce, 1968. p. 21. (National Bureau of Standards Monograph 110).

115 CHEN, X. et al. Interfacial water structure associated with phospholipid membranes studied by phase-sensitive vibrational sum frequency generation spectroscopy. Journal of the American Chemical Society (JACS), v. 132, n. 32, p. 11336-11342, 2010.

116 CALDERÓN, F. J. et al. Chemical differences in soil organic matter fractions determined by diffuse-reflectance mid-infrared spectroscopy. Soil Science Society of America Journal, v. 75, n. 2, p. 568, 2011.

117 KUMIRSKA, J. et al. Application of spectroscopic methods for structural analysis of chitin and chitosan. Marine Drugs, v. 8, n. 5, p. 1567-636, 2010.

118 ZHANG, B. et al. A mid-infrared spectroscopy method to determine the glucosamine, galactosamine, and muramic acid concentrations in soil hydrolysates. Soil Science Society of America Journal, v. 77, n. 3, p. 842, 2013. 